SYSTEMATIC REVISION OF THE ANDEAN SCORPION GENUS OROBOTHRIURUS MAURY, 1976 (BOTHRIURIDAE), WITH DISCUSSION OF THE ALTITUDE RECORD FOR SCORPIONS

JOSÉ A. OCHOA, ANDRES A. OJANGUREN AFFILASTRO, CAMILO I. MATTONI, AND LORENZO PRENDINI

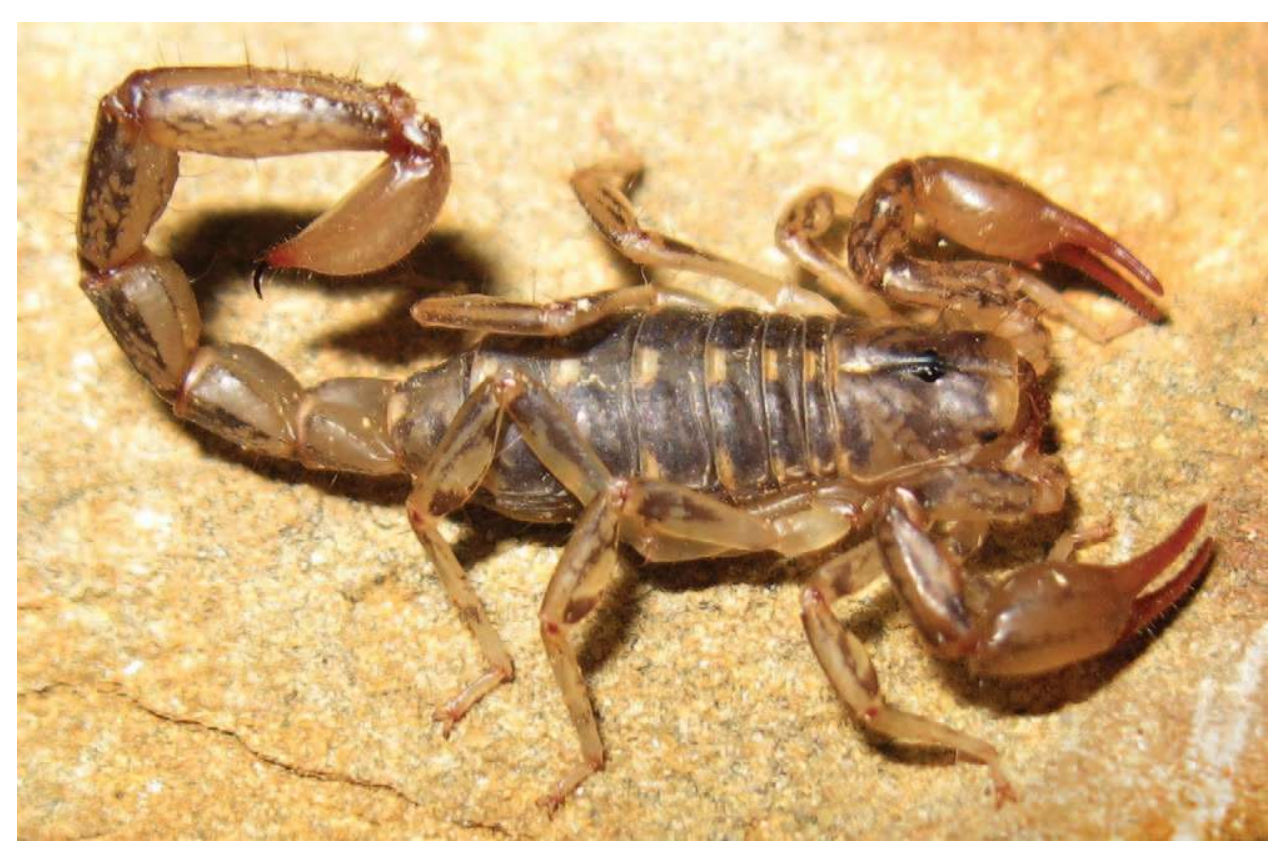




\title{
SYSTEMATIC REVISION OF THE ANDEAN SCORPION GENUS OROBOTHRIURUS MAURY, 1976 (BOTHRIURIDAE), WITH DISCUSSION OF THE ALTITUDE RECORD FOR SCORPIONS
}

\author{
JOSÉ A. OCHOA ${ }^{1,2}$ \\ ANDRES A. OJANGUREN AFFILASTRO ${ }^{3}$ \\ CAMILO I. MATTONI ${ }^{4}$ \\ LORENZO PRENDINI $^{1}$ \\ ${ }^{1}$ Scorpion Systematics Research Group, \\ Division of Invertebrate Zoology, \\ American Museum of Natural History, \\ Central Park West at 79th Street, New York, \\ NY, 10024-5192 \\ ${ }^{2}$ Departamento de Zoologia, \\ Instituto de Biociências, \\ Universidade de São Paulo, Rua do Matão, \\ travessa 14, 101, São Paulo, SP, 05508-900, Brazil \\ ${ }^{3}$ Museo Argentino de Ciencias Naturales \\ “Bernardino Rivadavia," Avenida Ángel Gallardo \\ 470, CP: 1405DJR, Buenos Aires, Argentina \\ ${ }^{4}$ Laboratorio de Biología Reproductiva y \\ Evolución, Cátedra de Diversidad Animal I, \\ Facultad de Ciencias Exactas, Físicas y Naturales, \\ Universidad Nacional de Córdoba, Av. \\ Vélez Sarsfield 299, 5000, Córdoba, Argentina
}

\footnotetext{
BULLETIN OF THE AMERICAN MUSEUM OF NATURAL HISTORY Number 359, 90 pp., 54 figures, 3 tables

Issued November 23, 2011
} 


\section{CONTENTS}

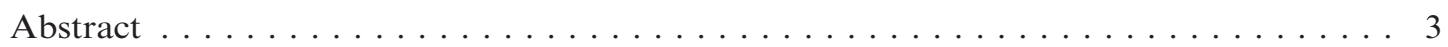

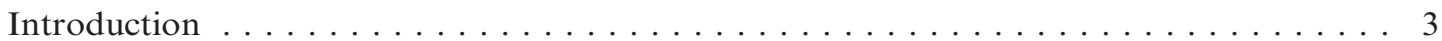

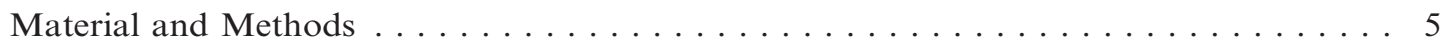

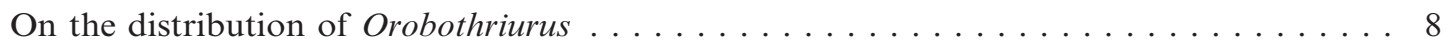

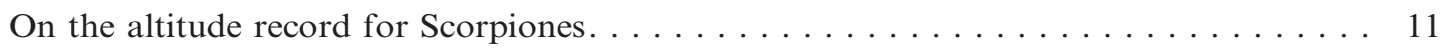

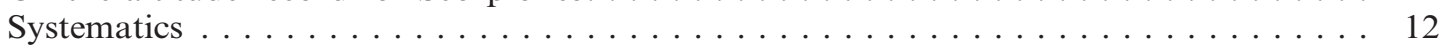

Orobothriurus (Maury, 1976) . . . . . . . . . . . . . . . . . . . . . . 12

Key to identification of the species of Orobothriurus . . . . . . . . . . . . . 14

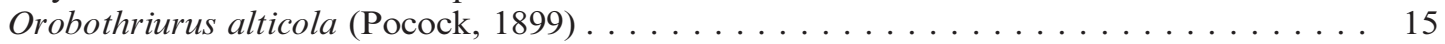

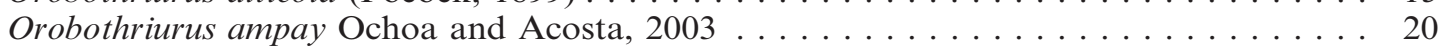

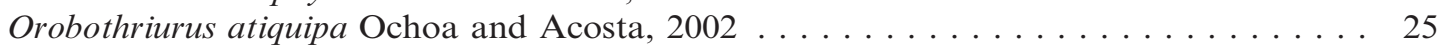

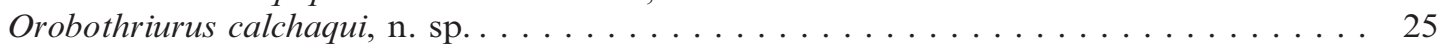

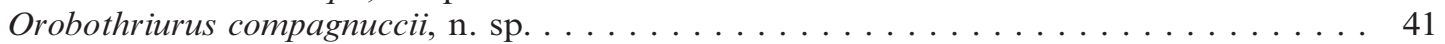

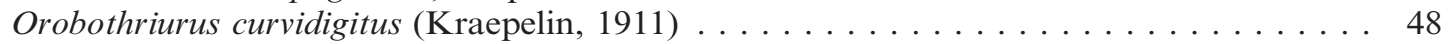

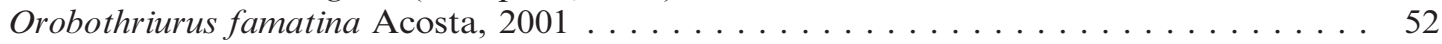

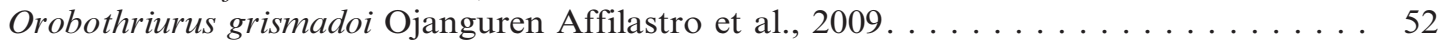

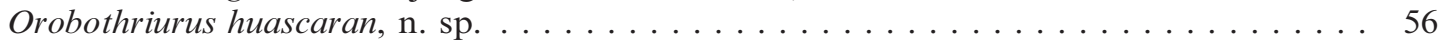

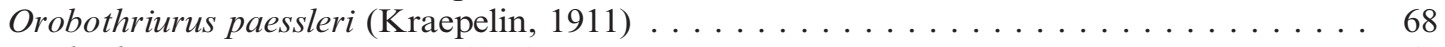

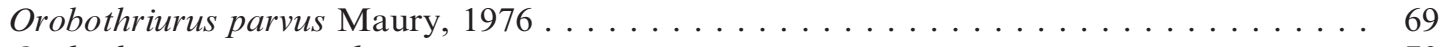

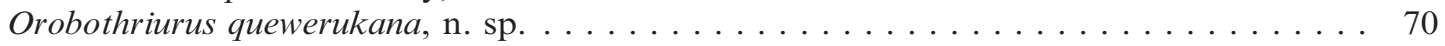

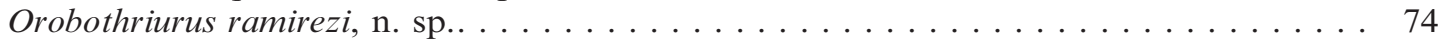

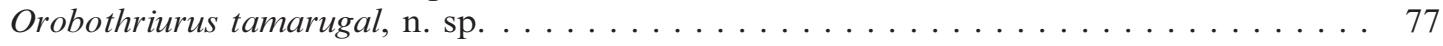

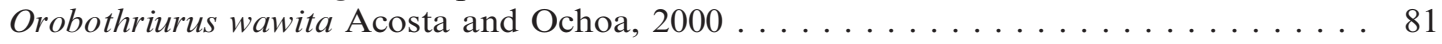

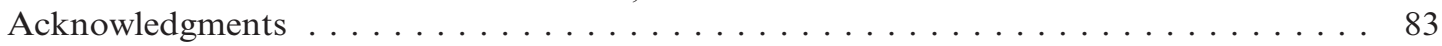

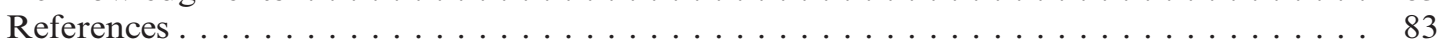

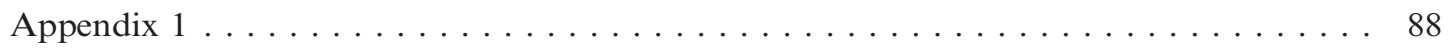

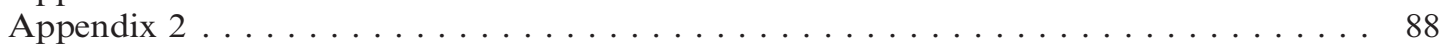




\begin{abstract}
The systematics of the Andean scorpion genus, Orobothriurus Maury, 1976 (Bothriuridae Simon, 1880), is revised. New locality records, obtained during recent field expeditions, distribution maps, and a key to identification of the 15 known species, are provided. Six new species are described: Orobothriurus calchaqui, n. sp., from northwestern Argentina; Orobothriurus compagnuccii, n. sp., from the central Andes of Argentina; Orobothriurus huascaran, n. sp., from central Peru; Orobothriurus quewerukana, n. sp., from southern Peru and northern Chile; Orobothriurus ramirezi, n. sp., from central Chile; and Orobothriurus tamarugal, n. sp., from northern Chile. The known distribution of Orobothriurus and the altitude record for scorpions are discussed. The world's altitude record for a scorpion, previously reported as $5550 \mathrm{~m}$, is demonstrated to be $4910 \mathrm{~m}$.
\end{abstract}

\section{INTRODUCTION}

The genus Orobothriurus Maury, 1976, comprises several fairly small scorpion species from the high altitudes and arid zones of central-western and southern South America (figs. 1-4). The genus is endemic to the Andes Cordillera, extending from central Peru (Cordillera Blanca in Ancash Department) to central-western Argentina, including western Bolivia, northern and central Chile, and northern and western Argentina (fig. 1). The southernmost record is the El Nevado mountain range in Mendoza Province, Argentina (Ojanguren Affilastro et al., 2009; figs. $1,3 \mathrm{D}, 54)$.

After its original description (Maury, 1976), this genus received little attention from taxonomists, mostly due to the scarcity of specimens in collections and the inaccessibility of the habitats where these scorpions occur, notably the high Andes Mountains, where each species is range restricted and microhabitat specific. This situation changed in recent years, as result of many expeditions conducted in the Andes of Argentina, Chile, and Peru, mostly by members of our research group.

Orobothriurus initially included eight species (Maury, 1976): Orobothriurus alticola (Pocock, 1899); Orobothriurus curvidigitus (Kraepelin, 1911); Orobothriurus paessleri (Kraepelin, 1911); Orobothriurus peruvianus (Mello-Leitão, 1948); Orobothriurus dumayi (Cekalovic, 1974); Orobothriurus crassimanus Maury, 1976; Orobothriurus inca Maury, 1976, and Orobothriurus parvus Maury, 1976. Five of these were originally placed in Bothriurus Peters, 1861. The following species were added subsequently: Orobothriurus wawita Acosta and Ochoa, 2000; Orobothriurus famatina Acosta, 2001; Orobothriurus iskay Acosta and Ochoa, 2001; Orobothriurus atiquipa Ochoa and Acosta, 2002, Orobothriurus ampay Ochoa and Acosta, 2003; Orobothriurus lourencoi Ojanguren Affilastro, 2003; Orobothriurus grismadoi Ojanguren Affilastro et al., 2009. Orobothriurus dumayi was returned to Bothriurus (Acosta and Ochoa, 2001; Mattoni and Acosta, 2006). Two species groups, alticola and inca, were also recognized in the genus (Maury, 1976; Acosta and Ochoa, 2001), but the monophyly of Orobothriurus remained doubtful (Prendini, 2000). Based on a cladistic analysis, Ochoa (2004a) described a new genus, Pachakutej Ochoa, 2004, to accommodate the four species of the inca group: Pachakutej crassimanus (Maury, 1976); Pachakutej inca (Maury, 1976); Pachakutej iskay (Acosta and Ochoa, 2001); Pachakutej peruvianus (Mello-Leitão, 1948). In the most recent taxonomic developments on this genus, Acosta (2002) transferred the enigmatic taxon, Cercophonius brachycentrus var. $\beta$ bivittatus Thorell, 1877, to Orobothriurus, and subsequently (Acosta, 2005) recognized it as a valid species. Orobothriurus bivittatus (Thorell, 1877) was later synonymized with $O$. alticola (Ojanguren Affilastro et al., 2009).

In the present contribution we describe six new species of Orobothriurus from Argentina, Chile and Peru, collected during recent field expeditions, raising to fifteen the number of species in the genus (table 1; appendix 1), and present new records and comprehensive distribution maps for the other 10 species, along with a key to the identification of all species in the genus. 


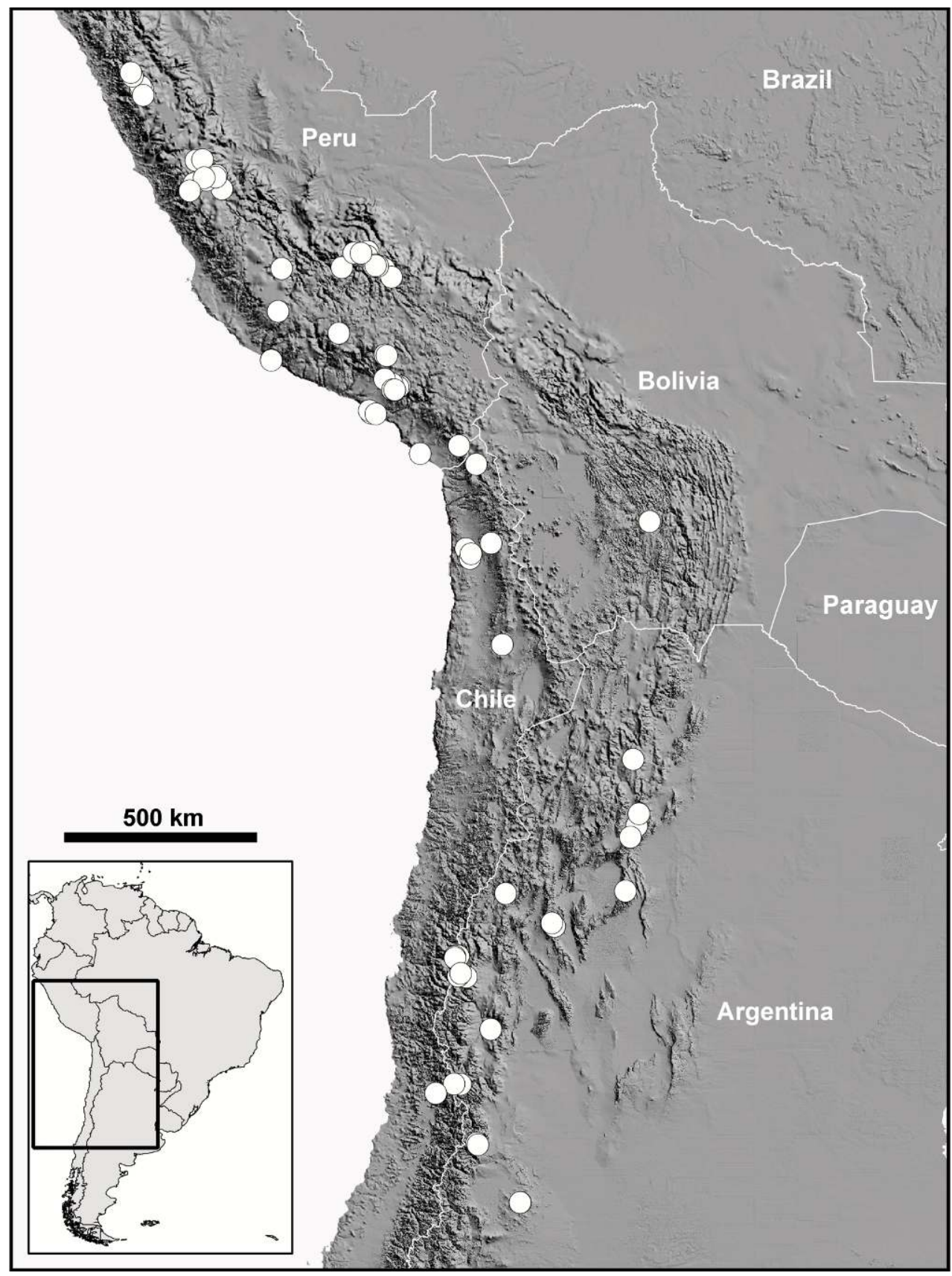

Fig. 1. Orobothriurus Maury, 1976, map of the distribution of the genus plotting known locality records. 


\section{MATERIAL AND METHODS}

Scorpion specimens were collected by turning stones during the day, or by ultraviolet (UV) light detection at night (Stahnke, 1972). Portable UV lamps, comprising mercury vapor tubes attached to a chromium reflector, and powered by a $12 \mathrm{~V}, 7 \mathrm{amp} /$ hour battery, or Maglite ${ }^{\circledR}$ flashlights modified with UV LED attachments, were used in fieldwork.

Material is deposited in the following collections: American Museum of Natural History, New York (AMNH); Natural History Museum, London, U.K. (BMNH); Cátedra de Diversidad Animal I, Facultad de Ciencias Exactas, Físicas y Naturales, Universidad Nacional de Córdoba, Argentina (CDA); František Kovařík Private Collection, Prague, Czech Republic (FKPC); Field Museum of Natural History, Chicago. (FMNH); Instituto Argentino de Investigaciones de las Zonas Áridas, Mendoza, Argentina (IADIZA); Instituto Miguel Lillo, Tucumán, Argentina (IML); Luís Eduardo Acosta Private Collection, Córdoba, Argentina (LEA); Laboratorio de Biología Reproductiva y Evolución, Universidad Nacional de Córdoba, Argentina (LBRE); Museo Argentino de Ciencias Naturales "Bernardino Rivadavia", Buenos Aires, Argentina (MACN-Ar); Museo de Historia Natural, Universidad Nacional de San Antonio Abad del Cusco, Peru (MHNC); Muséum d'Histoire Naturelle de Genève, Switzerland (MHNG); Museo de Historia Natural, Universidad Nacional Mayor de San Marcos, Lima, Peru (MUSM); Museo Regionale di Scienze Naturali, Turin, Italy (MRSN); Museu de Zoologia, Universidade de São Paulo, Brazil (MZSP); Museo de Zoología de la Universidad de Concepción, Chile (MZUC); Naturhistoriska Riksmuseet, Stockholm, Sweden (NRS); Zoologisches Museum, Universität Hamburg, Germany (ZMH).

Measurements $(\mathrm{mm})$ were recorded with an ocular micrometer, and illustrations of external morphology produced using a Nikon SMZ 1500 stereomicroscope with a camera lucida. Ultraviolet fluorescence images were produced using a Microptics ML1000 digital imaging system, or a $\mathrm{Nikon}^{\circledR}$ DS-Fi1-U2 digital camera, attached to a
Nikon ${ }^{\circledR}$ SMZ 1500 steremicrocope, under long-wave UV light. Habitus images were taken using the Microptics ML-1000 system, or a Nikon ${ }^{\circledR}$ D100 digital camera, under visible light. Hemispermatophores where dissected in ethanol and manually extracted from the tissues of the paraxial organs. Illustrations of hemispermatophores were produced with a camera lucida fitted to a Leica M 165C stereomicroscope. Photographs of hemispermatophores were taken with a Leica DFC 290 camera fitted to a Leica M 165C stereomicroscope.

Morphological terminology follows Vachon (1974) for trichobothrial nomenclature; Vachon (1952) and Prendini (2000) for pedipalp carinae, abbreviated as follows: internomedian (IM), dorsointernal (DI), dorsomedian (DM), dorsoexternal (DE), externomedian (EM), ventroexternal (VE), ventromedian (VM), ventrointernal (VI), dorsal patellar process (DPP), ventral patellar process (VPP), digital (D), dorsal secondary (DS), dorsomarginal (DMA), external (E); Mattoni and Acosta (2005) for macrosetae of the metasomal segments; Stahnke (1970) for other characters; a modified version of Prendini (2004) used by Ochoa et al. (2010) for carinae of the tergites, sternites, and metasoma, abbreviated as follows: dorsolateral (DL), lateral supramedian (LSM), lateral median (LM), lateral inframedian (LIM), ventrolateral (VL), ventrosubmedian (VSM), ventromedian (VM). Hemispermatophore terminology follows Ochoa (2004a) and Mattoni and Acosta (2005).

Point-locality records were georeferenced in the field with a portable GPS (Garmin ${ }^{\circledR}$ Etrex, Garmin ${ }^{\circledR}$ Vista or Garmin ${ }^{\circledR}$ II), or retroactively using the GeoNet Names Server (GNS, http://earth-info.nga.mil/gns/html/).

Distribution maps were generated using ArcMap 9.0 (Enviromental Systems Research Institute [ESRI], Redlands, California), by superimposing point locality records of species on coverages depicting political boundaries and topography. The topographic coverage (as a shaded relief) was generated from digital elevation model files (1 arc degree resolution) from the United States Geological Survey (USGS) (http://edc.usgs.gov/products/ elevation/gtopo30/gtopo30.html). 

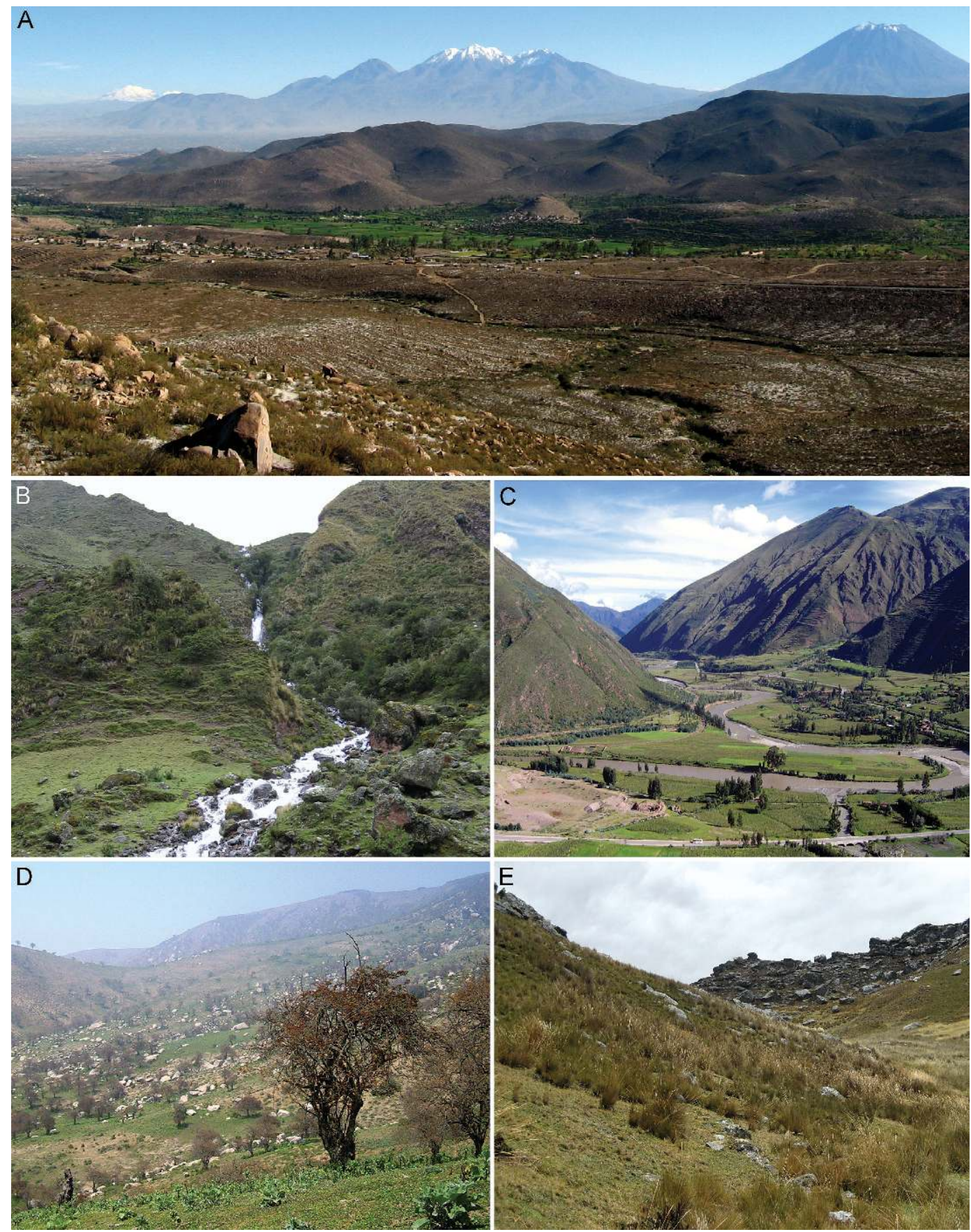

Fig. 2. Orobothriurus Maury, 1976, habitats in Peru. A. Polobaya, Arequipa (Arequipa Department), habitat of Orobothriurus curvidigitus (Kraepelin, 1911). B. Pacchac, Urubamba (Cusco Department), habitat of Orobothriurus wawita Acosta and Ochoa, 2000. C. Quiquijana, inter-Andean valley near Cusco (Cusco Department), habitat of O. wawita. D. Lomas Atiquipa (Arequipa Department), habitat of Orobothriurus atiquipa Ochoa and Acosta, 2002. E. Puna, central Peru (Junin Department), habitat of Orobothriurus parvus Maury, 1976. 


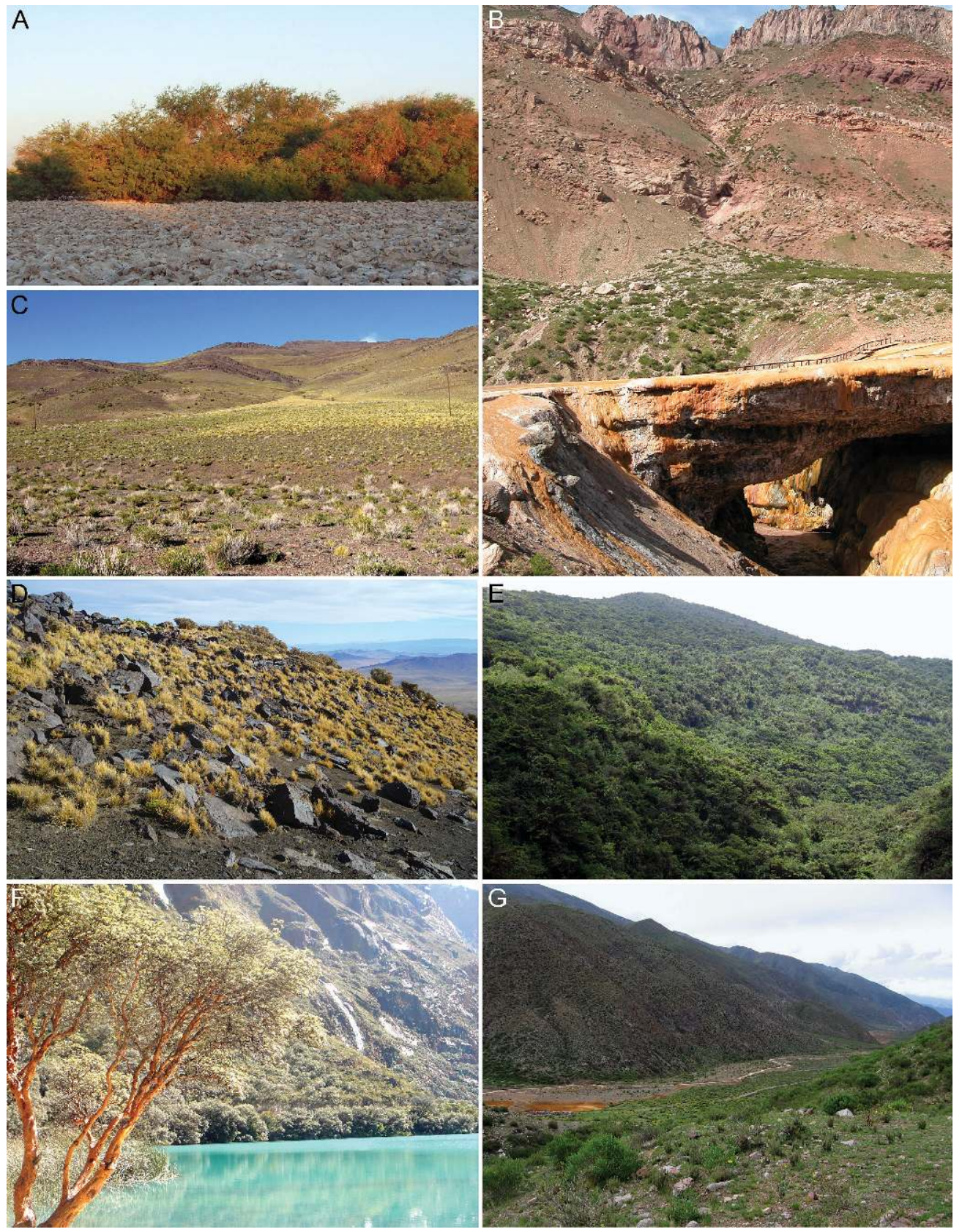

Fig. 3. Orobothriurus Maury, 1976, habitats in Argentina, Chile and Peru. A. Pampa de Tamarugal (Tarapacá Region, Chile), habitat of Orobothriurus tamarugal, n. sp. B. Puente del Inca (Mendoza Province, Argentina), habitat of Orobothriurus alticola (Pocock, 1899). C. El Tontal (Mendoza Province, Argentina), habitat of $O$. alticola. D. Cerro Nevado (Mendoza Province, Argentina), habitat of Orobothriurus grismadoi Ojanguren-Affilastro et al., 2009. E. Ampay, Abancay (Apurimac Department, Peru), habitat of Orobothriurus ampay Ochoa and Acosta, 2003. F. Llanganuco (Ancash Department, Peru), habitat of Orobothriurus huascaran, n. sp. G. Sierra de Famatina (La Rioja Province, Argentina), habitat of Orobothriurus famatina Acosta, 2001. 

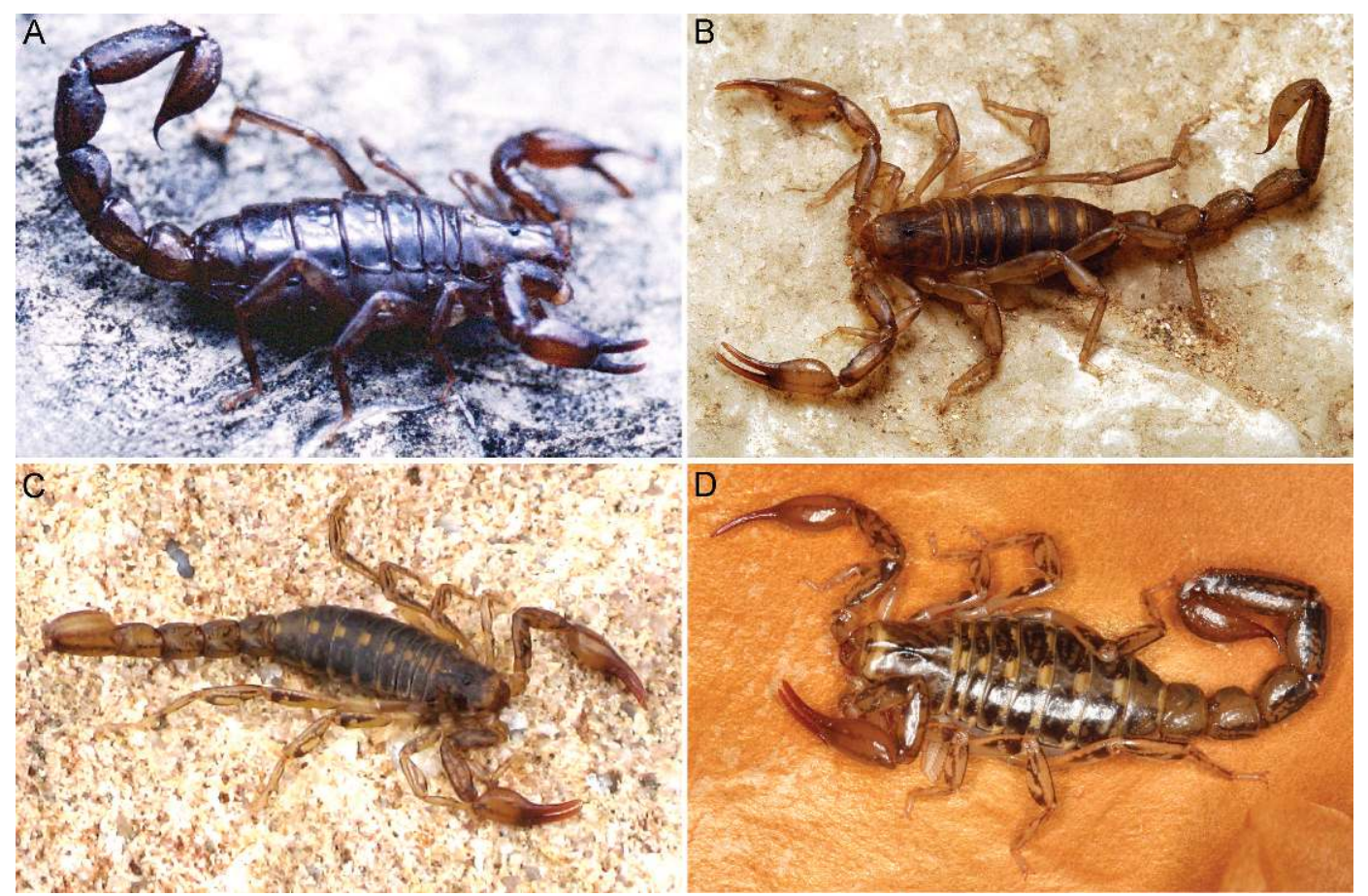

Fig. 4. Orobothriurus Maury, 1976, habitus in life. A. Orobothriurus ampay Ochoa and Acosta, 2003, +. B. Orobothriurus grismadoi Ojanguren-Affilastro et al., 2009, \&. C. Orobothriurus parvus Maury, 1976,

․ D. Orobothriurus huascaran, n. sp., + .

\section{ON THE DISTRIBUTION OF OROBOTHRIURUS}

Most species of Orobothriurus inhabit the Andes and orographic systems of Argentina,
Bolivia, Chile and Peru, where they have been collected up to $4910 \mathrm{~m}$. However, some species occur at low altitude near the Pacific coast (figs. 1, 53). All Orobothriurus species are allopatric (figs. 52-54). This pattern of

TABLE 1

Currently recognised species of the scorpion genus Orobothriurus Maury, 1976, with countries and provinces (Argentina), regions (Chile) or departments (Peru) from which they have been recorded. Orobothriurus lourencoi Ojanguren Affilastro, 2003, is excluded as this species will be placed in another genus (Mattoni et al., in litt.)

Orobothriurus alticola (Pocock, 1899)

Orobothriurus ampay Ochoa and Acosta, 2003

Orobothriurus atiquipa Ochoa and Acosta, 2002

Orobothriurus calchaqui, n. sp.

Orobothriurus compagnuccii, n. sp.

Orobothriurus curvidigitus (Kraepelin, 1911)

Orobothriurus famatina Acosta, 2001

Orobothriurus grismadoi Ojanguren Affilastro et al., 2009

Orobothriurus huascaran, n. sp.

Orobothriurus paessleri (Kraepelin, 1911)

Orobothriurus parvus Maury, 1976

Orobothriurus quewerukana, n. sp.

Orobothriurus ramirezi, n. sp.

Orobothriurus tamarugal, n. sp.

Orobothriurus wawita Acosta and Ochoa, 2000
Argentina: Mendoza, San Juan

Peru: Apurímac

Peru: Arequipa

Argentina: Tucumán

Argentina: La Rioja

Peru: Arequipa

Argentina: La Rioja

Argentina: Mendoza

Peru: Ancash

Peru: Arequipa

Peru: Junin, Lima

Chile: Tarapacá, Peru: Tacna

Chile: Coquimbo

Chile: Tarapacá

Peru: Ayacucho, Cusco 
distribution is probably related to the origin and subsequent development of the Andes, which promoted geographical isolation of Orobothriurus populations and speciation by vicariance (Ochoa, 2005).

Orobothriurus and another bothriurid genus, Brachistosternus Pocock, 1893, are the most diverse scorpion genera in the high Andes (Ojanguren Affilastro, 2003b; Ochoa, 2005). There are several records of Orobothriurus species occurring in sympatry with Brachistosternus species, e.g.: O. alticola with Brachistosternus montanus Roig Alsina, 1977; O. quewerukana with Brachistosternus quiscapata Ochoa and Acosta, 2002; O. ramirezi with Brachistosternus perettii Ojanguren Affilastro and Mattoni, 2006; O. tamarugal with Brachistosternus donosoi Cekalovic, 1974; $O$. wawita with Brachistosternus andinus Chamberlin, 1916. However, there are also vast areas in the Altiplano of southern Peru, western Bolivia, and northwestern Argentina where Orobothriurus have not been recorded, although the vegetation, altitude, and climate of these areas appear suitable (fig. 1). Thus far, only Brachistosternus have been recorded there.

Although the distribution of Orobothriurus generally follows the Andes, these scorpions occur in a variety of different habitats, at altitudes ranging from sea level, close to the Pacific coast, to the high Andes. Two species, $O$. atiquipa and $O$. paeslleri, inhabit Lomas biotopes below $1000 \mathrm{~m}$ in southern Peru (figs. 2D, 53; Ochoa, 2005). Orobothriurus tamarugal inhabits an isolated forest of Prosopis tamarugo Phil. (Fabaceae) in northern Chile (figs. 3A, 53). The remaining species occur in different Andean habitats above $2500 \mathrm{~m}$, including semi-arid zones with scrub and thorny steppe on the western slopes of the Andes in Chile and Peru: $O$. curvidigitus and $O$. quewerukana (figs. 2A, 53); forest and/or shrub vegetation in the inter-Andean valleys of Peru: $O$. ampay and O. wawita (figs. 2B, C, 3E, 52); and highaltitude montane environments with typical Prepuna, Puna and Altoandina vegetation: $O$. alticola, O. calchaqui, O. compagnuccii, $O$. famatina, O. grismadoi, $O$. huascaran, $O$. parvus, and $O$ ramirez $i$ (figs. $2 \mathrm{E}, 3 \mathrm{~B}-\mathrm{D}, \mathrm{F}$, $\mathrm{G}, 52,54)$.
Most Orobothriurus species occur at high altitudes, e.g., O. alticola occurs up to $4000 \mathrm{~m}$ in central Argentina (fig. 3B, C), O. parvus up to $4700 \mathrm{~m}$ in central Peru (fig. 2E), and O. huascaran up to $4910 \mathrm{~m}$ in central Peru, the world's altitude record for a scorpion (fig. 3F). Drastic climatic conditions are experienced at these altitudes.

Species diversity reduces with increasing altitude in high mountains in many taxa (Lomolino, 2001). Few scorpion species are found in high mountain habitats (Polis, 1990; Lourenço and Qi, 2006). In South America, only 39 scorpion species have been recorded from above $3000 \mathrm{~m}$ in the Andes, from Argentina, Bolivia, Chile, Colombia, Ecuador and Peru (table 2). Thirty belong to the family Bothriuridae Simon, 1880, the remaining nine to Buthidae C.L. Koch, 1837, Chactidae Pocock, 1893, and Iuridae Thorell, 1876, and are mostly restricted to central and northern South America, where the climatic conditions at higher altitude are more favorable. Two bothriurid genera dominate these montane biotopes: Orobothriurus (12 species, $80 \%$ of the species in the genus) and Pachakutej (four species, 66\%) (Maury, 1976; Ochoa 2004a, 2005; Ojanguren Affilastro et al., 2009). Another bothriurid genus, Brachistosternus, contains 12 species in the high Andes, but this number represents only $29 \%$ of the species in the genus (Roig Alsina, 1977; Maury, 1978, 1979; Ochoa and Acosta, 2002b; Ojanguren Affilastro, 2002, 2003b, 2004; Ochoa, 2004b, 2005; Ojanguren Affilastro and Mattoni, 2006; Ojanguren Affilastro et al., 2007b; Ojanguren Affilastro and Ramirez, 2009). Four other genera are represented by only a few species at these high altitudes: Hadruroides Pocock, 1893 (two species, 12\% of the species in the genus), Teuthraustes Simon, 1878 (two species, 10\%), Bothriurus Peters, 1861 (two species, 4\%), and Tityus C.L. Koch, 1836 (five species, less than 2\%) (Maury, 1979; Francke and Soleglad, 1980; Lourenço and Maury, 1985; Lourenço, 1995; Acosta, 1997; Acosta and Ochoa, 2001; Flórez, 2001; Acosta, 2005; Lourenço, 2005; Ochoa, 2005; Ojanguren Affilastro, 2005; Ochoa and Chaparro, 2008; Ochoa and Prendini, 2010). 
TABLE 2

Scorpion species recorded above $3000 \mathrm{~m}$ in the Andes

References: 1: Acosta, 1997; 2: Acosta, 2005; 3: Acosta and Ochoa, 2000; 4: Acosta and Ochoa, 2001; 5: Acosta and Ochoa, 2002; 6: Flórez, 2001; 7: Francke and Soleglad, 1980; 8: Maury, 1976; 9: Maury, 1978; 10: Maury, 1979; 11: Maury, 1984; 12: Lourenço, 1995; 13: Lourenço, 2005; 14: Lourenço and Maury, 1985; 15: Ochoa, 2004a; 16: Ochoa, 2004b; 17: Ochoa, 2005; 18: Ochoa and Acosta, 2002b; 19: Ochoa and Acosta, 2003; 20: Ochoa and Chaparro, 2008; 21: Ojanguren Affilastro, 2002; 22: Ojanguren Affilastro, 2003b; 23: Ojanguren Affilastro, 2004; 24: Ojanguren Affilastro, 2005; 25: Ojanguren Affilastro and Mattoni, 2006; 26:

Ojanguren Affilastro et al., 2007; 27: Ojanguren Affilastro et al., 2007; 28: Ojanguren Affilastro et al., 2009; 29: Roig Alsina, 1977; 30: This article; 31: Unpublished data.

\begin{tabular}{|c|c|c|c|c|}
\hline Family & Species & Altitude & Country & Reference \\
\hline Bothriuridae & Orobothriurus huascaran, n. sp. & $3730-4910 \mathrm{~m}$ & Peru & 30 \\
\hline Bothriuridae & Orobothriurus parvus Maury, 1976 & $3400-4750 \mathrm{~m}$ & Peru & 8,30 \\
\hline Bothriuridae & $\begin{array}{l}\text { Brachistosternus montanus Roig Alsina, } \\
1977\end{array}$ & $2700-4540 \mathrm{~m}$ & Argentina & $24,29,31$ \\
\hline Bothriuridae & $\begin{array}{l}\text { Brachistosternus galianoae Ojanguren } \\
\text { Affilastro, } 2002\end{array}$ & $4300-4500 \mathrm{~m}$ & Bolivia & 21,31 \\
\hline Bothriuridae & $\begin{array}{l}\text { Brachistosternus piacentinii Ojanguren } \\
\quad \text { Affilastro, } 2003\end{array}$ & $4300-4500 \mathrm{~m}$ & Bolivia, Chile & 22,27 \\
\hline Bothriuridae & Bothriurus bocki Kraepelin, 1911 & $2440-4360 \mathrm{~m}$ & Bolivia & 5,11 \\
\hline Bothriuridae & Orobothriurus calchaqui, n. sp. & $2700-4300 \mathrm{~m}$ & Argentina & 30 \\
\hline Bothriuridae & $\begin{array}{l}\text { Brachistosternus intermedius Lönnberg, } \\
\quad 1902\end{array}$ & $2500-4252 \mathrm{~m}$ & Argentina, Bolivia & $23,24,31$ \\
\hline Buthidae & Tityus argentinus scaber (Werner, 1939) & $4200 \mathrm{~m}$ & Bolivia & 6 \\
\hline Buthidae & Tityus chilensis Lourenço, 2006 & $4080 \mathrm{~m}$ & Chile & 13 \\
\hline Bothriuridae & Brachistosternus ninapo Ochoa, 2004 & $2900-4050 \mathrm{~m}$ & Peru & 16,17 \\
\hline Bothriuridae & Orobothriurus ramirezi, n. sp. & $3300-4030 \mathrm{~m}$ & Chile & 30 \\
\hline Bothriuridae & Orobothriurus alticola (Pocock, 1899) & $2700-4005 \mathrm{~m}$ & Argentina & $2,8,10,24,28,30$ \\
\hline Bothriuridae & Bothriurus olaen Acosta, 1997 & $600-4000 \mathrm{~m}$ & Argentina & 1,31 \\
\hline Bothriuridae & $\begin{array}{l}\text { Brachistosternus titicaca Ochoa and } \\
\text { Acosta, } 2002\end{array}$ & $3850-3900 \mathrm{~m}$ & Bolivia, Peru & 17,18 \\
\hline Bothriuridae & Orobothriurus compagnuccii, n. sp. & $3200-3900 \mathrm{~m}$ & Argentina & 30 \\
\hline Bothriuridae & $\begin{array}{l}\text { Orobothriurus wawita Acosta and } \\
\text { Ochoa, } 2000\end{array}$ & $2700-3800 \mathrm{~m}$ & Peru & $3,17,30$ \\
\hline Bothriuridae & Orobothriurus quewerukana, n. sp. & $2822-3732 \mathrm{~m}$ & Chile, Peru & 30 \\
\hline Bothriuridae & $\begin{array}{l}\text { Brachistosternus kovariki Ojanguren } \\
\quad \text { Affilastro, } 2003\end{array}$ & $3200-3600 \mathrm{~m}$ & Chile & 22,27 \\
\hline Bothriuridae & $\begin{array}{l}\text { Brachistosternus perettii Ojanguren } \\
\text { Affilastro and Mattoni, } 2006\end{array}$ & $3200-3600 \mathrm{~m}$ & Chile & 25,27 \\
\hline Bothriuridae & $\begin{array}{l}\text { Orobothriurus curvidigitus (Kraepelin, } \\
\text { 1911) }\end{array}$ & $2300-3600 \mathrm{~m}$ & Peru & $8,17,30$ \\
\hline Bothriuridae & $\begin{array}{l}\text { Orobothriurus ampay Ochoa and } \\
\text { Acosta, } 2003\end{array}$ & $3100-3550 \mathrm{~m}$ & Peru & 17,19 \\
\hline Bothriuridae & $\begin{array}{l}\text { Brachistosternus quiscapata Ochoa and } \\
\text { Acosta, } 2002\end{array}$ & $3000-3400 \mathrm{~m}$ & Chile, Peru & 17,18 \\
\hline Iuridae & $\begin{array}{l}\text { Hadruroides bustamantei Ochoa and } \\
\text { Chaparro, } 2008\end{array}$ & $2600-3379 \mathrm{~m}$ & Peru & 20,31 \\
\hline Bothriuridae & $\begin{array}{l}\text { Brachistosternus andinus Chamberlin, } \\
\quad 1916\end{array}$ & $2780-3350 \mathrm{~m}$ & Peru & 9,17 \\
\hline Bothriuridae & Pachakutej oscari Ochoa, 2004 & $3250-3300 \mathrm{~m}$ & Peru & 15,17 \\
\hline Chactidae & Teuthraustes atramentarius Simon, 1878 & $2500-3300 \mathrm{~m}$ & Ecuador & 12,31 \\
\hline Buthidae & Tityus footei Chamberlin, 1916 & $800-3300 \mathrm{~m}$ & Peru & 14,17 \\
\hline Bothriuridae & $\begin{array}{l}\text { Brachistosternus prendinii Ojanguren } \\
\text { Affilastro, } 2003\end{array}$ & $2800-3200 \mathrm{~m}$ & Chile & 22,27 \\
\hline Bothriuridae & Orobothriurus famatina Acosta, 2001 & $2500-3200 \mathrm{~m}$ & Argentina & $4,24,30$ \\
\hline Chactidae & Teuthraustes oculatus Pocock, 1900 & $2920-3150 \mathrm{~m}$ & Ecuador & 12,31 \\
\hline
\end{tabular}


TABLE 2

(Continued)

\begin{tabular}{|c|c|c|c|c|}
\hline Family & Species & Altitude & Country & Reference \\
\hline Bothriuridae & $\begin{array}{l}\text { Orobothriurus grismadoi Ojanguren } \\
\text { Affilastro et al., } 2009\end{array}$ & $2900-3130 \mathrm{~m}$ & Argentina & 28 \\
\hline Iuridae & $\begin{array}{l}\text { Hadruroides mauryi Francke and } \\
\text { Soleglad, } 1980\end{array}$ & $2750-3100 \mathrm{~m}$ & Peru & 7,17 \\
\hline Bothriuridae & $\begin{array}{l}\text { Pachakutej peruvianus (Mello-Leitão, } \\
\text { 1948) }\end{array}$ & $2600-3100 \mathrm{~m}$ & Peru & 8,31 \\
\hline Buthidae & Tityus columbianus (Thorell, 1876) & $2200-3100 \mathrm{~m}$ & Colombia & 6 \\
\hline Bothriuridae & Pachakutej inca (Maury, 1976) & $3000 \mathrm{~m}$ & Peru & 8 \\
\hline Bothriuridae & $\begin{array}{l}\text { Brachistosternus coquimbo Ojanguren } \\
\text { Affilastro et al., } 2007\end{array}$ & $2850-3000 \mathrm{~m}$ & Chile & 26 \\
\hline Bothriuridae & $\begin{array}{l}\text { Pachakutej iskay (Acosta and Ochoa, } \\
\text { 2001) }\end{array}$ & $2800-3000 \mathrm{~m}$ & Peru & 4,17 \\
\hline Buthidae & Tityus soratensis Kraepelin, 1911 & $2800-3000 \mathrm{~m}$ & Bolivia, Peru & $5,14,17$ \\
\hline
\end{tabular}

\section{ON THE ALTITUDE RECORD FOR SCORPIONES}

Polis (1990: 252) reported the highest known altitude record for a scorpion as $5550 \mathrm{~m}$ for Pachakutej crassimanus (Maury, 1976) (as Orobothriurus crassimanus) in the Peruvian Andes, based on a personal communication by W.R. Lourenço. Lourenço (1997: 598) amended the data to $5560 \mathrm{~m}$, providing more details about the localities and collection data, recorded in 1981 at Nevado Huascarán (Peru). Subsequent authors cited this as the altitude record for a scorpion species (Coddington and Colwell, 2001; Lourenço, 2002, 2003; Lourenço and Qi, 2006; Prendini, 2006). Unfortunately, this record is both erroneous and based on a misidentification.

We reviewed the material studied by W.R. Lourenço, deposited in MHNG. This material is labelled from the following localities: "Llanganuco, Nevado de Huascarán" (3 + , 4300 m; 2 ㅇ, 4400-5500 m; 1 §े, $5560 \mathrm{~m}$ ); "Laguna Parón" (1,+ 4000 m); "Quebrada QuerocochaCatac" (1 ô, 2 क , $3900 \mathrm{~m}$ ); and "Recuay, Huama" (2 s, 4 o, 14 juv., $4200 \mathrm{~m}$ ). We could not locate the fourth locality record (Huama), which probably corresponds to Huaraz (see Material Examined for O. huascaran). All except one of these specimens are conspecific with $O$. huascaran, not $P$. crassimanus. Pachakutej crassimanus is known only from the type locality at $2850 \mathrm{~m}$, in the Cajamarca Department of northern Peru, $230 \mathrm{~km}$ from Huascarán (Maury, 1976; Ochoa, 2004a), and does not occur at Llanganuco.
The exception is an adult male specimen labelled "Llanganuco, Nevado Huascarán, $5560 \mathrm{~m}$," which is not $P$. crassimanus but a species of Hadruroides Pocock, 1893 (Iuridae), as illustrated by Lourenço's (1997: 589) figures 1 and 2 . The locality data for this misidentified specimen, allegedly collected at $5560 \mathrm{~m}$, are obviously erroneous. No $\mathrm{Ha}$ druroides species have been recorded above $4000 \mathrm{~m}$ (Maury, 1975; Ochoa and Prendini, 2010), although Hadruroides are present in Yungay, at the bottom of the valley between $2500 \mathrm{~m}$ and $3000 \mathrm{~m}$, just $12 \mathrm{~km} \mathrm{SW}$ of Laguna Llanganuco. Nevado Huascarán, the highest mountain in Peru $(6768 \mathrm{~m})$, gives its name to the surrounding Huascarán National Park. The mountain trail to Nevado Huascarán starts in Yungay and continues through the Llanganuco ravine. The misidentified Hadruroides specimen was therefore probably collected near Yungay.

The altitude data for the remaining $\mathrm{MNHG}$ specimens of $O$. huascaran from Llanganuco, collected at $4000 \mathrm{~m}, 4300 \mathrm{~m}, 4400 \mathrm{~m}$, and $5500 \mathrm{~m}$, are also imprecise. Laguna Llanganuco or Chinancocha is situated at $3835 \mathrm{~m}$ and we assume that the specimens were collected on the ascent to Nevado Huascarán (Llanganuco ravine), probably in the vicinity of the base camp (4100 m). It is unlikely that scorpions survive above $5200 \mathrm{~m}$, or even lower in certain areas, as the ground is permanently covered by snow and ice (glacier). When the area was visited in 1998, suitable habitats for scorpions and other arthropods 
existed up to about $5100 \mathrm{~m}$. Due to the effects of global warming and the retreat of glaciers, this altitude may have increased during the past decade. However, when the MHNG specimens were collected in 1981, the snow line was considerably lower (Byers, 2000).

In light of the above deductions, we correct the altitude record for scorpions. Based on available data, the world's altitude record for a scorpion is $4910 \mathrm{~m}$ for $O$. huascaran, collected in the Ishinca ravine $\left(09^{\circ} 22^{\prime} 28^{\prime \prime} \mathrm{S} 77^{\circ} 24^{\prime} 36^{\prime \prime} \mathrm{W}\right)$, Huaraz Province, central Peru, not $5550 \mathrm{~m}$ for Pachakutej crassimanus (Maury, 1976) as published (Polis, 1990; Lourenço, 1997, 2002, 2003; Coddington and Colwell, 2001; Lourenço and Qi, 2006; Prendini, 2006).

\section{SYSTEMATICS}

\section{FAMILY BOTHRIURIDAE SIMON, 1880 OROBOTHRIURUS Maury, 1976}

Bothriurus "group C - Bothriurus coriaceus" Mello-Leitão, 1934: 62 (part).

Bothriurus (Andibothriurus) Bücherl et al., 1963: 209 (part) [nomen nudum, nec Bothriurus (Andibothriurus) Maury, 1976: 15].

Orobothriurus Maury, 1976: 14-17 (part), type species by original designation: Bothriurus alticola Pocock, 1899 [= Orobothriurus alticola (Pocock, 1899)]; Francke, 1977: 75 (part); Maury, 1979: 709; Francke, 1985: 11, 15 (part); Sissom, 1990: 87, 88 (part); Lourenço, 1997: 588 (part); Acosta and Maury, 1998: 550, 554, 559; Lowe and Fet, 2000: 35-37 (part); Acosta and Ochoa, 2000: 137 (part); 2001: 203, 205 (part); Lourenço and Dastych, 2001: 54 (part); Ochoa and Acosta, 2002a: 98, 99; 2003: 1, 2; Soleglad and Fet, 2003: 88 (part); Ojanguren Affilastro, 2003a: 117 (part); Ochoa, 2004a: 52-55, 73, figs. 1-2, 8-9, 20A-B, 21; Acosta, 2005: 2; Fet and Soleglad, 2005: 13; Ochoa, 2005: 55, 56, 65, figs. 7, 16; Ojanguren Affilastro, 2005: 80, 82, 176, 177; Prendini and Wheeler, 2005: 481; Rein, 2007: 5; Dupré, 2007: 8, 12; Ojanguren Affilastro et al., 2009: 28.

Orobothriurus "alticola group": Acosta and Ochoa, 2001: 205; Ochoa and Acosta, 2002a: 99; 2003: 2; Ojanguren Affilastro, 2003a: 117.

Diagnosis: The genus Orobothriurus comprises small, slender scorpions, varying from $18.3 \mathrm{~mm}$ (male $O$. wawita) to $51.5 \mathrm{~mm}$ (female $O$. quewerukana) in total length. Orobothriurus may be distinguished from other bothriurid genera by the distinctive morphology of the hemispermatophore (fig. 10), which is slender with a reduced lobe region. The frontal crest of the hemispermatophore is divided in two parts: the proximal part is oblique and the distal part straight with a lateral projection on both the ental and ectal surfaces. The basal lobe forms a tortuous stem with a typical subdistal spatulate dilation.

The genus may be further distinguished on the following diagnostic characters. The male pedipalp chela manus possesses an acuminate conical apophysis on the internal surface. Trichobothrium $i b$ is situated at the base of this apophysis. The VSM carinae of metasomal segment $\mathrm{V}$ are arranged in parallel and situated close to the VL carinae. The female genital opercula are more elongated posteriorly, with more rounded anterior edges, than those of other bothriurid genera.

REMARKS: The characters shared by most Orobothriurus species are as follows. The coloration is usually yellowish. The pigmentation pattern of the mesosoma typically comprises two sublateral spots on each tergite, leaving an unpigmented median stripe along the length of the mesosoma (fig. 13C, $\mathrm{E}-\mathrm{G})$, except in $O$. ampay, in which tergites I-VII are completely pigmented (fig. 12D), and $O$. grismadoi, in which tergite VII is almost completely pigmented (fig. 13G).

The metasomal segments usually exhibit a single VM and paired VL stripes (figs. 11B, $\mathrm{C}, 13 \mathrm{~A})$. The VM stripe is contiguous with the paired VL stripes in the posterior third of the segment (fig. 11A) in $O$. ampay, and absent in $O$. wawita (fig. 13D). The carapace anterior margin is almost straight, either with a weak median projection (epistome) or a shallow median notch. The anteromedian longitudinal sulcus is complete but weakly developed, the posteromedian longitudinal sulcus well developed, the median ocular tubercle low, and situated anteromedially on the carapace (figs. 14-16). The metasomal segments are elongated, with variable carinal development (figs. 17-22). The DL carinae occupy the entire length of segments I-IV, and usually comprise granules of medium size. The ML, LIM, and VL carinae are variable, usually present on segments I and II. The LSM carinae are absent or obsolete. 
The VSM carinae are present on segments I and II in most species (figs. 17-19), extending to IV in $O$. ampay (fig. 17B). The VM carina of metasomal segment $\mathrm{V}$ is granular (figs. 20, $21 \mathrm{~A}, \mathrm{~B}, \mathrm{D}-\mathrm{F}, 22)$, except in the male of $O$. wawita, in which it is absent (fig. 21C). The VSM carinae are arranged in parallel and situated close to the VL carinae, except in $O$. atiquipa and $O$. wawita, where they are absent (figs. 21A, C, 22F). Metasomal segment I possesses 2 or 3 pairs of VL and VSM macrosetae, II and III each possess 3 pairs, IV, 3-5 pairs, and V, 3 or 4 pairs (fig. 6). The male telson vesicle is narrower than that of the female, with a weakly developed dorsal gland that is not always apparent (fig. 23).

The sternum is transverse with 2 or 4 macrosetae. The genital operculum is divided longitudinally, comprising two subtriangular sclerites, joined by flexible tissue in the anterior half, each sclerite tapering posteriorly, the sclerites of females being more elongated posteriorly, with the anterior edges more rounded (fig. 9) than those of males.

Each pecten comprises more than 10 teeth, fulcra, and a single row of median lamellae, the first being dilated (fig. 9). The cheliceral manus possesses 2 or 3 macrosetae near the movable finger articulations. The movable finger possesses two subdistal teeth and is more strongly curved in the male than the female. The ventrointernal margin of the fixed finger and ventral surface of the movable finger are setose basally.

The basitarsi possess two well-developed, symmetric pedal spurs. The telotarsi are elongated, with a ventromedian row of elongated spinules, and well-developed pro- and retroventral rows of spiniform macrosetae with the following formula on legs I-IV: $1 / 1$, $2 / 2,3 / 3,3 / 3$, except in $O$. atiquipa, which has $3 /$ 4 spiniform macrosetae in the pro- and retroventral on legs III and IV. The telotarsal ungues are curved and symmetric.

The pedipalps are usually elongated, especially in adult males, with a slender, prismatic chela in most species. The male chela manus of all species, except $O$. ampay and $O$. wawita, possesses an acuminate conical apophysis on the internal surface (fig. 8B). The pedipalp chelal carinae are usually absent or obsolete, evident only by differences in the angles between surfaces, but at least the D, DS,
DMA, DI, and VM carinae may be identified, depending on the species, with vestigial VI and IM carinae also evident in several species (Ochoa, 2004a). The median denticle row of the chela fingers comprises 4-6 pairs of internal and external accessory denticles.

The pedipalp trichobothriotaxy is neobothriotaxic major Type C (Vachon, 1974; figs. 7,8$)$. The femur possesses three trichobothria $(d, i, e)$. The patella possesses 19 trichobothria, one of which is petite $\left(e s b_{2}\right)$ : one internal $(i)$, two dorsal $\left(d_{1}, 2\right)$, three ventral $\left(v_{1-3}\right)$, and 13 external (et $t_{1-3}$, est, $\left.e m_{1,2}, e s b_{1,2}, e b_{1-5}\right)$. The chela possesses 27 trichobothria, including one accessory trichobothrium in the $V$ series, and two petite trichobothria $\left(E t_{4}, E s b\right): 18$ trichobothria are situated on the chela manus $\left(E t_{1-5}, E s t, E s b\right.$, $\left.E b_{1-3}, V_{1-5}, D t, D b, d b\right)$ and nine on the fixed finger (et, est, esb, eb, dt, dst, dsb, it, ib). Macroseta $\mathbf{M}_{1}$ is situated near trichobothrium $e$ on the pedipalp femur (fig. 7A). On the pedipalp chela, trichobothrium $d b$ is situated medially; $E t_{3}$ is situated either in the same same axis as, or proximal to Est; Esb is situated either between $E b_{2}$ and $E b_{3}$ or dorsal to $E b_{2} ; V_{1}, V_{2}$, and $V_{3}$ are situated in the same axis; $d s t$ is situated proximal to est; $D b$ is equidistant between $D t$ and $E b_{3}$ (except in $O$. huascaran); $E t_{5}$ forms an obtuse angle with $e b$ and $E t_{4}$ (fig. 8A); and $i b$ is situated at the base of the apophysis on the internal surface of the chela manus of adult males, where it is not visible in ventral view (fig. $8 \mathrm{C}$ ).

The hemispermatophore is lamelliform and slender (fig. 10). The elongated distal lamina is separated into two parts, a basal portion delimited by the frontal crest, and a distal portion termed the apex (Ochoa, 2004a). The apex comprises two parts, a narrow base termed the pedicel, and a subtriangular distal part that includes the distal crest. The frontal crest is further divided into two parts: the proximal part is oblique and possesses two lateral folds, the distal part is straight and usually parallel to the ventral margin of the lamina, with a lateral projection on both the ental and ectal surfaces. The distal edge exhibits a small incision and, in most species, there is a constriction along the border at the point of inflexion. The shape and length of the apex and frontal crest vary among the species (figs. 27, 28, 32, 36, 40, and 47). The lobe 
region is greatly reduced, the capsular concavity is shorter than the fold of the internal lobe, and the basal lobe forms a tortuous stem with a subdistal spatulate dilation ending in a terminal process (fig. 10).

INCLUDED TAXA: Fifteen species (table 1). Orobothriurus lourencoi Ojanguren Affilastro, 2003, will be placed in another genus based on phylogenetic analysis (fig. 5, appendix 2; Mattoni et al., in litt.).

Distribution: Orobothriurus is endemic to Argentina, Bolivia, Chile and Peru (table 1). Five of the described species are endemic to Argentina, two to Chile and seven to Peru.

\section{KEY TO IDENTIFICATION OF THE SPECIES OF OROBOTHRIURUS}

1. Tergites I-VI entirely and densely pigmented (fig. 12D); metasomal segments I-V, VM stripe contiguous with paired VL stripes posteriorly (fig. 11A); metasomal segment IV, VSM carinae present (fig. 16B); angle formed between pedipalp chela trichobothria $e b-E t_{5}$ $E t_{4}$ less than $90^{\circ}$ (fig. 25A). . . . O. ampay Tergites I-VI each with paired lateral spots of pigmentation delimiting unpigmented median longitudinal stripe (fig. 13C, E-G); metasomal segments I-V, VM stripe not contiguous with paired VL stripes posteriorly (at least on segments IV and V; figs. 11B-D, 13A, D); metasomal segment IV, VSM carinae absent (fig. 17A); angle formed between pedipalp chela trichobothria $e b-E t_{5}-E t_{4}$ greater than $90^{\circ}$ (fig. 25B, D) . . . . . . . . . . 2

2. Carapace, anterior margin with weak median projection (epistome) (fig. 14C, 15A, C, D); pedipalp chela, movable finger ( $\hat{\delta}$ ) distinctly curved (fig. 26B, C). . . . . . . . . . . 3 Carapace, anterior margin sublinear or emarginate, with shallow median notch (figs. 14A, $\mathrm{B}, \mathrm{D}, 15 \mathrm{~B}, 16)$; pedipalp chela, movable finger ( $\delta$ ) straight (figs. 25B, D, 31C). . 6

3. Metasomal segment V (ㅇ) slightly elongated, length greater than or equal to twice its width (fig. 22C); metasomal segment I with two pairs of VSM macrosetae (fig. 19A, C, F); pedipalp chela, movable finger ( $\hat{\sigma}$ ) strongly curved (figs. 26C, 43C, 51A) . . . . . 4 Metasomal segment V ( + ), length less than twice its width (fig. 22B); metasomal segment I with three pairs of VSM macrosetae (fig. 19B); pedipalp chela, movable finger (o) slightly curved (fig. 26B) . . O. paessleri
4. Carapace, tergites, metasomal segments, ventral surface unpigmented (fig. 49); sternite VII finely granular (fig. 19F); metasomal segments I-IV, VSM carinae present, at least on segments I and II (fig. 19F); hemispermatophore, frontal crest shorter than apex length, ventral border of distal part of apex straight (fig. 47C, D) . . . . . O. tamarugal Carapace, tergites, metasomal segments, ventral surface pigmented (figs. 11B, 13E); sternite VII smooth or nearly so (fig. 19A, C); metasomal segments I-IV, VSM carinae absent (fig. 19A, C); hemispermatophore, frontal crest slightly elongated, length greater than or equal to apex length, ventral border of distal part of apex slightly curved (figs. 28B, $\mathrm{D}, 38 \mathrm{D}, \mathrm{E}) \ldots \ldots \ldots \ldots \ldots \ldots \ldots$

5. Carapace, tergites, metasomal segments, and pedipalps markedly pigmented (figs. 11B, 12C, $13 \mathrm{E}$ ); telson vesicle, ventral surface ( $\delta$ ) granular in anterior third; pedipalp chela, trichobothrium $E s b$ situated between trichobothria $E b_{2}$ and $E b_{3}$; hemispermatophore, distal crest without folds (fig. 28B) . . . . O. curvidigitus Carapace and tergites faintly pigmented, metasomal segments and pedipalps unpigmented (fig. 41); telson vesicle, ventral surface ( $\hat{\sigma}$ ) entirely granular (fig. 23F); pedipalp chela, trichobothrium Esb situated dorsal to trichobothrium $E b_{2}$; hemispermatophore, distal crest with one or two small folds (fig. 40E) . . . . . . . . O. quewerukana

6. Hemispermatophore, frontal crest reduced, length less than apex length (figs. $27,36 \mathrm{~F}-\mathrm{H}$, $\mathrm{K}-\mathrm{O}) \ldots \ldots \ldots \ldots \ldots \ldots \ldots$ Hemispermatophore, frontal crest elongated, length greater than apex length (fig. 36D, E,

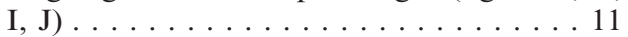

7. Metasomal segments I-III, dorsal surfaces each with two median subtriangular spots (occasionally absent on I), usually separated medially by narrow unpigmented line (fig. 12A, C); segment IV with three pairs of VSM macrosetae. . . . . . . . . . . 8

- Metasomal segments I-III, dorsal surfaces each without median spots, but with reticulate pigmentation along DL carinae (fig. 12B, 13C); segment IV with four or five pairs of VSM macrosetae (fig. 17A) . . . . . . . 10

8. Carapace, anterior margin with shallow median notch (fig. 14B); metasoma ( 今), VL and VSM carinae obsolete, granular on segment I, absent on II (fig. 18F); hemispermatophore apex $52 \%-54 \%$ of lamina length, terminal process of basal lobe well developed (figs. 32C, D, 36A-C) . . . O. compagnuccii Carapace, anterior margin with deep median notch (fig. 14A); metasoma ( $\delta$ ), VL and 
VSM carinae well developed, granular, occupying entire length of segment I and weakly developed but complete on II; hemispermatophore apex $66 \%-72 \%$ of lamina length, terminal process of basal lobe small (fig. 32A, B, 36F-H, K-O) . . . . . . . . . . 9

9. Metasomal segment IV with two or three pairs of ML macrosetae; segment III usually with one pair of DL macrosetae ... O. calchaqui Metasomal segment IV with one pair of ML macrosetae; segment III usually without DL macrosetae . . . . . . . . . O. famatina

10. Pedipalp chela manus ( $\delta$ ), internal surface with apophysis (fig. 8B); pedipalp chela fixed finger ( है) slightly curved, creating small gap with movable finger when fingers closed (fig. 22A); metasomal segment V, VL and VM carinae complete (fig. 22E); metasomal segments with distinct VM pigmentation stripe (at least on segments II-V); hemispermatophore, ventral border of apex slightly curved (fig. 27B) . . . . . . . . . O O parvus Pedipalp chela manus ( $\delta$ ), internal surface without apophysis (fig. 25C); pedipalp chela fixed finger ( $\hat{\sigma}$ ) straight, no gap evident when fingers closed (fig. 25B); metasomal segment $\mathrm{V}, \mathrm{VL}$ and VM carinae absent ( $\delta$; fig. 21C) or restricted to distal third ( $q$; fig. $22 \mathrm{~F})$; metasomal segments irregularly pigmented, VM pigmentation stripe indistinct (fig. 13D); hemispermatophore, ventral border of apex straight (fig. 27C) . . . . . . . . O. wawita

11. Metasoma segments I-III ( $(+)$, VSM carinae present (fig. 19D); segment V, VL and VM carinae restricted to posterior two-thirds (fig. 21F); pedipalp chela manus, trichobothrium $E s b$ situated between $E b_{2}$ and $E b_{3}, D b$ slightly closer to $D t$ than to $E b_{3}$ (fig. 39C); hemispermatophore, distal border of apex slightly rounded, frontal crest with internal lateral projection vestigial (fig. 40A-C) . . . .

O. huascaran Metasoma segments I-III ( + ), VSM carinae absent; metasomal segment V, VL, and VM carinae complete (fig. 20A, C, F); pedipalp chela manus, trichobothrium Esb situated dorsal to $E b_{2}, D b$ equidistant between $D t$ and $E b_{3}$ (figs. $25 \mathrm{D}, 46 \mathrm{~B}, \mathrm{C}$ ); hemispermatophore, distal border of apex subtriangular, frontal crest with internal lateral projection complete (figs. 28A, 47A, B) . . . . . . . 12

12. Sternite VII acarinate (fig. 18A); metasomal segment II ( $\hat{\delta})$, VSM carinae absent (fig. 18A); segment V, VSM and VM carinae not discernible from dense surface granulation (fig. 21A); legs III and IV, telotarsi each with 3/4 spiniform macrosetae in pro- and retroventral rows; metasomal segments I-III, paired VL stripes contiguous with VM stripe posteriorly (but not on segments IV and V) (fig. 11D); segment IV with four pairs of VSM macrosetae. . . . . . . . . O. atiquipa Sternite VII with one or two pairs of carinae (fig. 18C, D); metasomal segment II ( $§$ ), VSM carinae present; segment V, VM, and VL carinae well defined (figs. 20A, C, F, 21E); legs III and IV, telotarsi each with $3 / 3$ spiniform macrosetae in pro- and retroventral rows; metasomal segments $\mathrm{I}-\mathrm{V}$, paired VL stripes not contiguous with VM stripe posteriorly (fig. 11C); segment IV with three pairs of VSM macrosetae ............... 13

13. Hemispermatophore apex elongated, angle of inclination $135.18^{\circ}-139.1^{\circ}$ (fig. 36D, E); tergite VII entirely pigmented (fig. 13G); telson vesicle ( §) , dorsal surface concave (fig. 23E) . . . . . .

O. grismadoi

Hemispermatophore apex short, angle of inclination $138.99^{\circ}-144.99^{\circ}$ (figs. 36I, J, 47A, B); tergite VII with paired lateral spots of pigmentation delimiting unpigmented median longitudinal stripe (fig. 13F); telson vesicle (§), dorsal surface flat (fig. 23A) . . . . . 14

14. Hemispermatophore, distal crest extremely developed, extending almost entire length of lamina (fig. 47A, B); telson length/width ratio (s), 2.65-2.94 (mean $=2.78)$, (ㅇ), $2.13-2.37$ $($ mean $=2.27) \ldots \ldots \ldots \ldots$ O. ramirezi

- Hemispermatophore, distal crest restricted to distal half of lamina (fig. 36I); telson length/ width ratio $(\delta), 2.87-3.21$ (mean $=3.07)$, (ㅇ), $2.44-2.55($ mean $=2.49) \ldots$ O. alticola

Orobothriurus alticola (Pocock, 1899)

Figures 13F, 15B, 18D, 20A, 21A, 36I, J, 54

Cercophonius brachycentrus var. $\beta$ bivittatus Thorell, 1877: 183 [synonymized by Ojanguren Affilastro et al., 2009: 35].

Bothriurus alticola Pocock 1899: 357-358, fig. 1; Kraepelin, 1911: 91, 97; Mello-Leitão, 1931: 82, 92; 1932: 34; 1934: 63, 65; 1935: 93; 1937: 103; 1945: 138, 144, 145; Bücherl, 1959a: 23, 24, fig. 4; Abalos, 1959: 591; 1963: 113; Cekalovic, 1966: 3; Bücherl, 1969: 769; Maury, 1973: 110; Roig Alsina, 1973: 198; Masnú de Moreno, 1991: 184, 189, map 1.

Bothriurus (Andibothriurus) alticola: Bücherl et al., 1963: 217, 224, fig. 8.

Urophonius brachycentrus bivittatus: Mello-Leitão 1931: 99-100; 1932: 35; 1934: 48, 51; 1938: 94 95; 1945: 213, 215; Acosta and Maury, 1998: 559; Lowe and Fet, 2000: 44.

Urophonius brachicentrus bivittatus: Mello-Leitão, 1939: 612; Abalos, 1959: 592; 1963: 117; Roig Alsina, 1973: 200 [incorrect subsequent spelling]. 


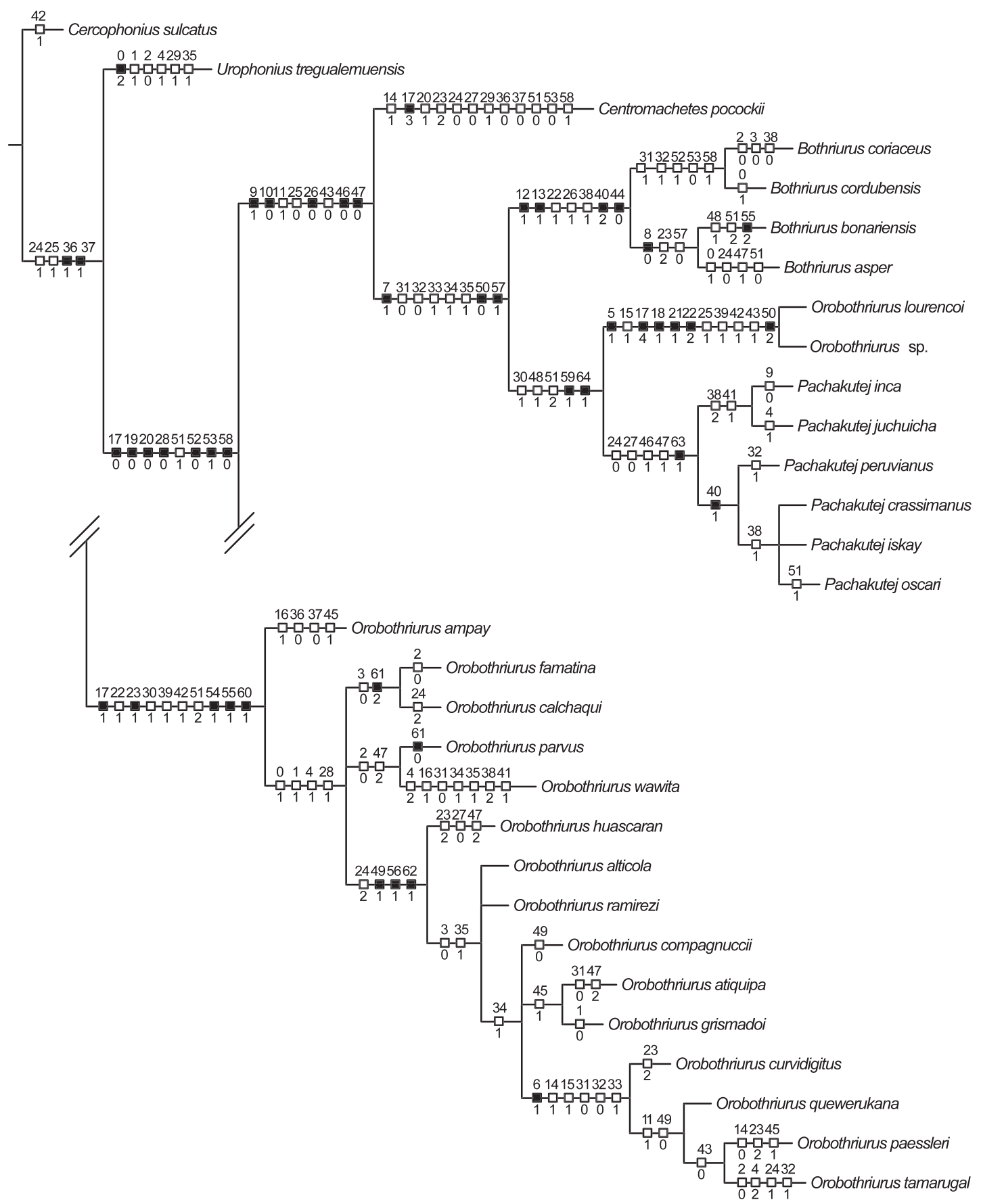

Fig. 5. Most parsimonious tree (length $=167$; CI: 0.479; RI: 0.813), obtained by cladistic analysis of 65 morphological characters (appendix 2) scored for 15 species of Orobothriurus Maury, 1976 , and 15 outgroup taxa with the implied weighting regime that maximized average support (Mattoni et al., in litt.). Synapomorphies optimized with accelerated transformation indicated with bars. Black bars indicate uniquely derived apomorphic states, white bars indicate parallel derivations of apomorphic states. Numbers above bars indicate characters, numbers below indicate states. 

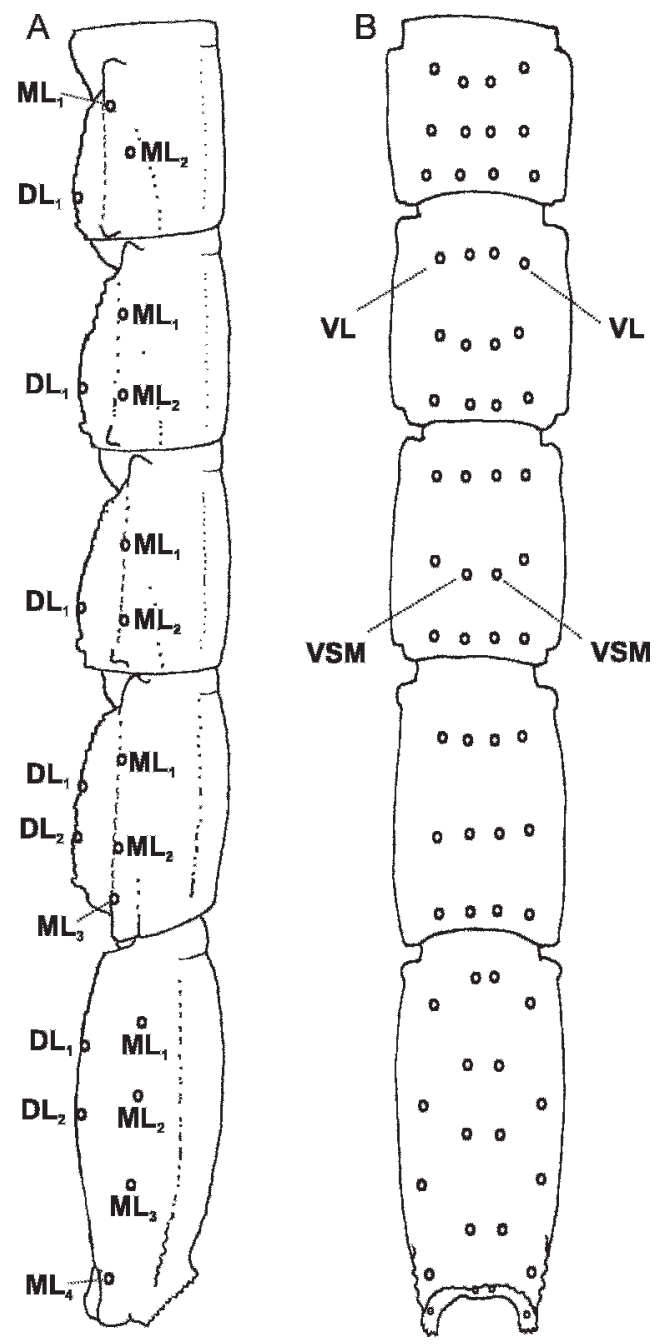

Fig. 6. Orobothriurus Maury, 1976, metasomal segments I-V showing distribution of macrosetae. A. Lateral aspect. B. Ventral aspect. Annotations: dorsolateral (DL); median lateral (ML); ventrolateral (VL); ventrosubmedian (VSM).

Orobothriurus bivitattus: Acosta, 2005: 3-12, figs. 1-8; Ojanguren Affilastro, 2005: 181-183, 220, 241; Acosta, 2006: 20, 21; ICZN, 2008: 69-70.

Orobothriurus alticola: Maury, 1976: 17-18, figs. 1-10, table 1 (part); 1979: 717, map 10 (part); 1981: 98 (part); Acosta and Maury, 1998: 559 (part); Kovař́k, 1998: 101; Acosta and Ochoa, 2000: 135, 136, 143; Lowe and Fet, 2000: 35; Acosta and Ochoa, 2001: 203-205, 208, 209; Acosta, 2002: 176, 177; Ochoa, 2004a: 44, 49, 50, 52, 55, figs. 1, 2, 21, table 1; Acosta, 2005: 1, 2, 8, 9, 12; Ojanguren Affilastro, 2005: 176, 178,
179, 180, 220, 241; Kamenz and Prendini, 2008: 39, pl. 111, table II; Ojanguren Affilastro et al., 2009: 35-40, figs. 2, 18, 19, 25-35, table 2 .

Type Material: ARGENTINA: Mendoza Province: Las Heras Department: 1 t, 1 q syntypes $(\mathrm{BMNH})$, Puente del Inca

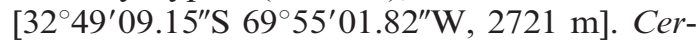
cophonius brachycentrus bivittatus: 1 juv. holotype (NRS), San Juan Province.

NeW ReCORds: ARGENTINA: Mendoza Province: Las Heras Department: Puente del Inca, $32^{\circ} 49.568^{\prime} \mathrm{S} \quad 69^{\circ} 54.606^{\prime} \mathrm{W}, 2759 \mathrm{~m}$, 2.xi.2003, J.A. Ochoa, L. Prendini and C.I. Mattoni, alpine vegetation (low spiny bushes) on hard, rocky ground, under stone, 1 juv. (AMNH [LP 2386]). San Juan Province: Calingastra Department: Cerro el Tontal, $31^{\circ} 31^{\prime} 24.7^{\prime \prime} \mathrm{S} 69^{\circ} 12^{\prime} 23.3^{\prime \prime} \mathrm{W}, 3600 \mathrm{~m}, 25.1$. 2006, A. Ojanguren Affilastro, L. Compagnucci and L. Piacentini, 2 juv. (AMNH [LP 5848]); between Paso de Agua Negra and Aduana, vega and surrounds, 30 17'33.1's $69^{\circ} 46^{\prime} 45.6^{\prime \prime} \mathrm{W}, 4005 \mathrm{~m}, 27.1 .2005$, C.I. Mattoni and A. Ojanguren Affilastro, UV sampling, 1 subad. ô, 1 subad.,+ 1 juv. ô (AMNH [LP 4309]).

Diagnosis: Orobothriurus alticola is similar to $O$. grismadoi in pigmentation pattern, external morphology, and hemispermatophore. The two species can be separated by the shape of the hemispermatophore: the apex is narrower, and the angle formed by the apex with the rest of the distal lamina smaller in $O$. grismadoi (fig. $36 \mathrm{D}$, E) than in O. alticola (fig. 36I, J). Males can also be separated by the shape of the telson, which is more slender in O. grismadoi. Additionally, the dorsal surface of the telson vesicle is concave in males of $O$. grismadoi, whereas it is flat in males of $O$. alticola (fig. 23A, E). Tergite VII is almost entirely pigmented, without an unpigmented median stripe, in O. grismadoi (fig. 13G), but exhibits paired lateral spots of pigmentation, delimiting an unpigmented median stripe, in $O$. alticola (fig. 13F). On the other hand, O. alticola can be separated from $O$. compagnuccii by the shape of the lamina of the hemispermatophore: the apex comprises $52.17 \%-54.54 \%$ $(n=3$; mean $=52.98 \%)$ of the lamina in $O$. compagnuccii and 40.87\%-46.08\% $(n=20$; mean $=43.88 \%$ ) in $O$. alticola. Orobothriurus alticola and $O$. ramirezi can be separated by 

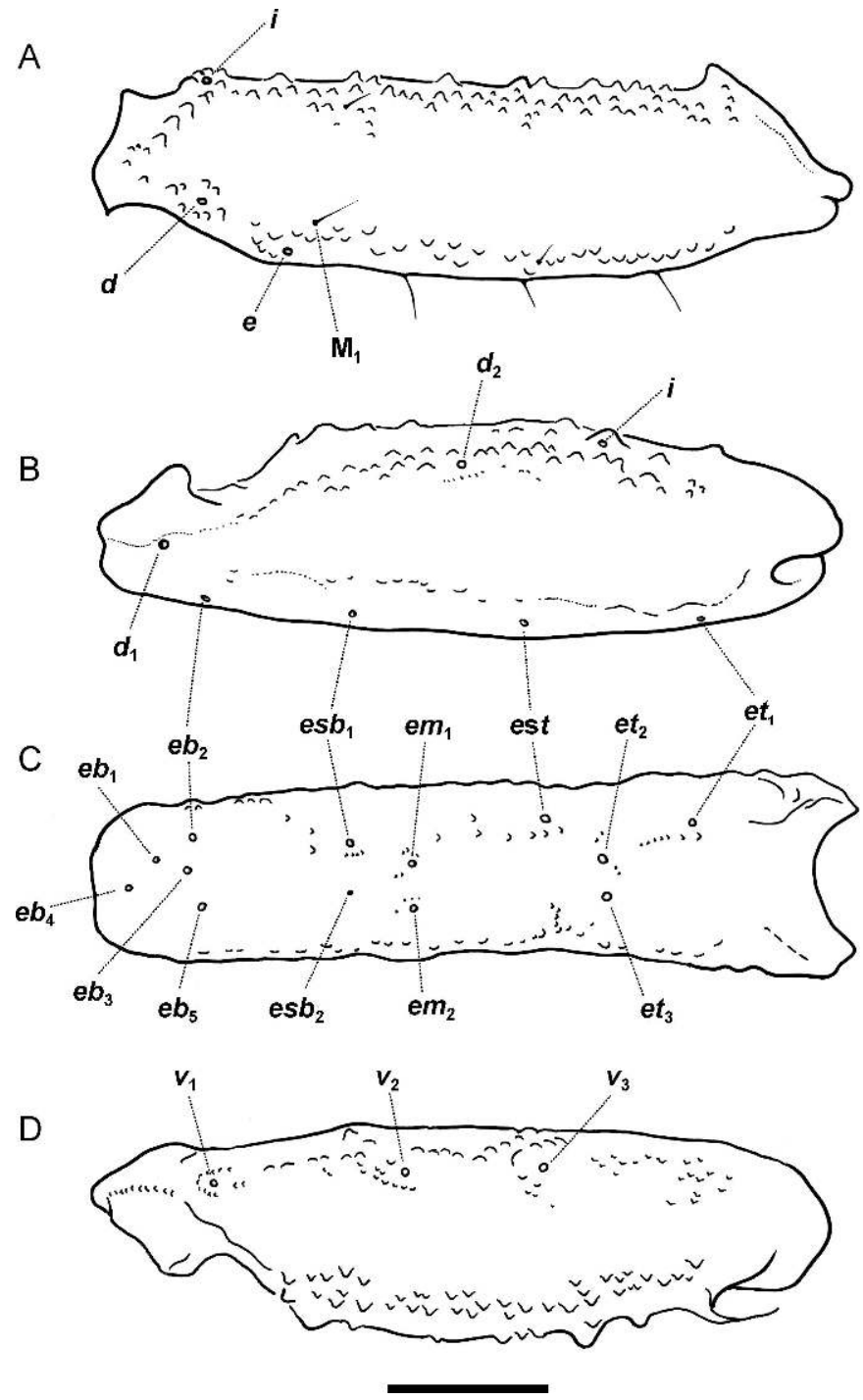

Fig. 7. Orobothriurus Maury, 1976, dextral pedipalp femur (A) and patella (C-D), showing trichobothrial pattern. A. Femur, dorsal aspect. B. Patella, dorsal aspect. C. Patella, external aspect. D. Patella, ventral aspect. Annotations: dorsal $(d)$; external (e); external basal (eb); external medial (em); external suprabasal $(e s b)$; external subterminal (est); external terminal (et); internal $(i)$; ventral $(v)$. Scale bar $=1 \mathrm{~mm}$.

the distal crest of the hemispermatophore, which is less developed, occupying only half the apex of the lamina, in $O$. alticola, than in $O$. ramirez $i$, in which it occupies almost the entire apex (figs. 36I, J, 47A, B). The telson vesicle of $O$. alticola is narrower, especially in females (telson length/width ratio: $\delta$, 2.87-3.21, mean $=3.07$; + , 2.44 2.55 , mean $=2.49$; fig. $23 \mathrm{~A})$ than that of $O$. ramirezi (telson length/width ratio: $\hat{\delta}, 2.65$
2.94 , mean $=2.78 ;$ ㅇ $2.13-2.37$, mean $=$ 2.27; figs. $23 \mathrm{G}, 24 \mathrm{E}$ ). The dorsal surface of the femur and ventral surface of the metasoma are less pigmented, with narrower stripes, in $O$. alticola than $O$. ramirezi. The metasomal carinae, especially the VL and VSM carinae of segments I and V, and the DL carinae of segment $\mathrm{V}$, are less developed in males of $O$. alticola than $O$. ramirez $i$ (fig. 20A, C). 


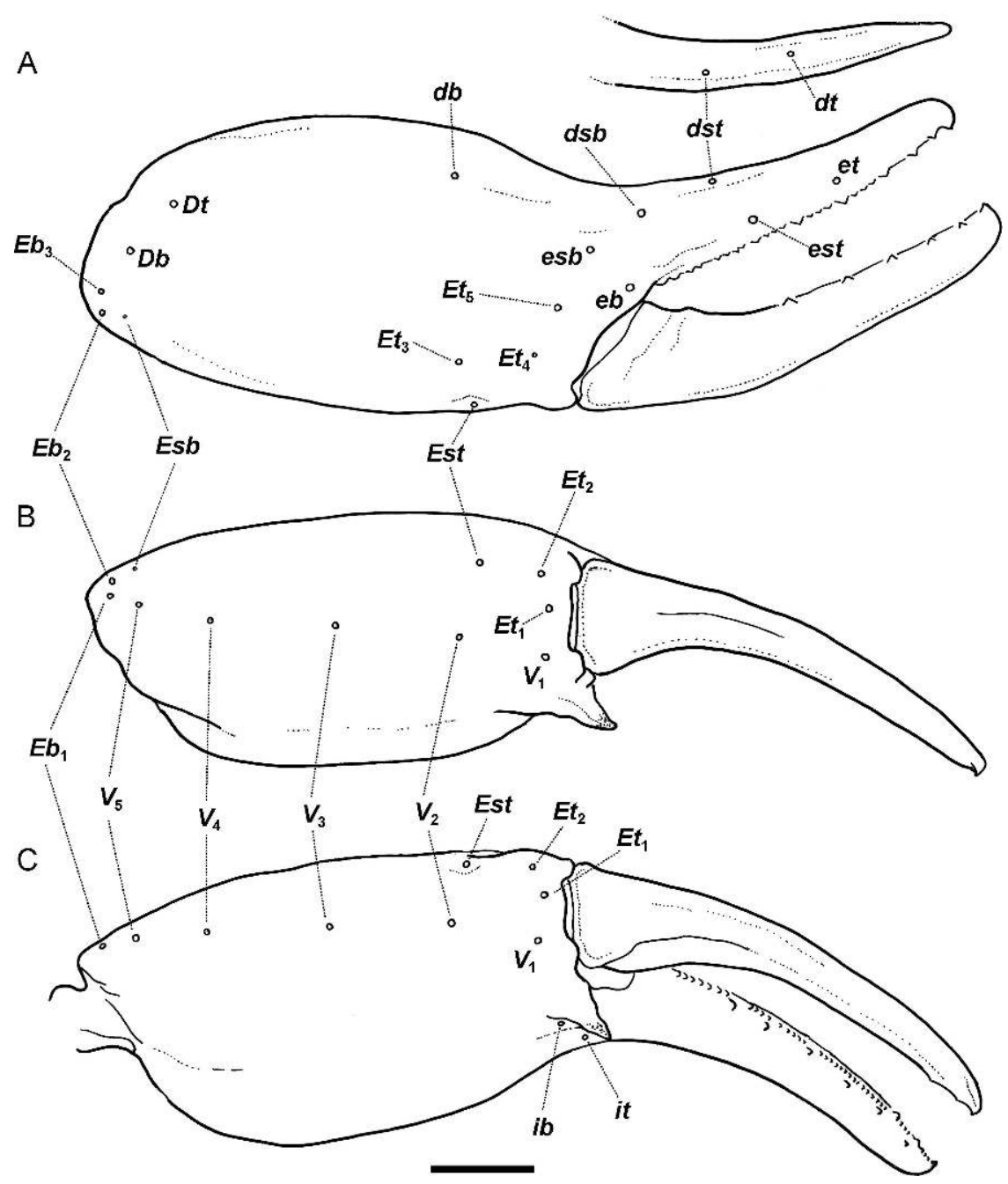

Fig. 8. Orobothriurus Maury, 1976, dextral pedipalp chela, showing trichobothrial pattern. A. External aspect, with dorsal aspect of fixed finger. B. Ventral aspect. C. Ventrointernal aspect. Annotations: dorsal basal $(d b, D b)$; dorsal suprabasal $(d s b)$; dorsal subterminal (dst); dorsal terminal (dt, $D t)$; external basal (eb, $E b)$; external suprabasal (esb, Esb); external subterminal (est, Est); external terminal (et, Et); internal basal $(i b)$; internal terminal $(i t)$; ventral $(V)$. Scale bar $=1 \mathrm{~mm}$.

REMARKS: Acosta (2002) transferred Cercophonius brachycentrus bivittatus to Orobothriurus, and subsequently redescribed it as a valid species based on a single male specimen (Acosta, 2005). Based on an examination of additional material, however, Ojanguren Affilastro et al. (2009) were unable to identify any characters by means of which this species could be consistently separated from $O$. alticola, and it was therefore synonymized.
DisTRIBUTION: Orobothriurus alticola is endemic to central-western Argentina, from the central part of Mendoza Province (Laguna Diamante) to the central part of San Juan Province (Paso del Agua Negra; fig. 54). It occurs at $2700-4000 \mathrm{~m}$ in the Andes (fig. 3B) and nearby El Tontal mountain range of the Precordillera (fig. 3C, Ojanguren Affilastro et al., 2009).

ECOLOGY: The area inhabited by $O$. alticola belongs to the Puna and the Altoandina 

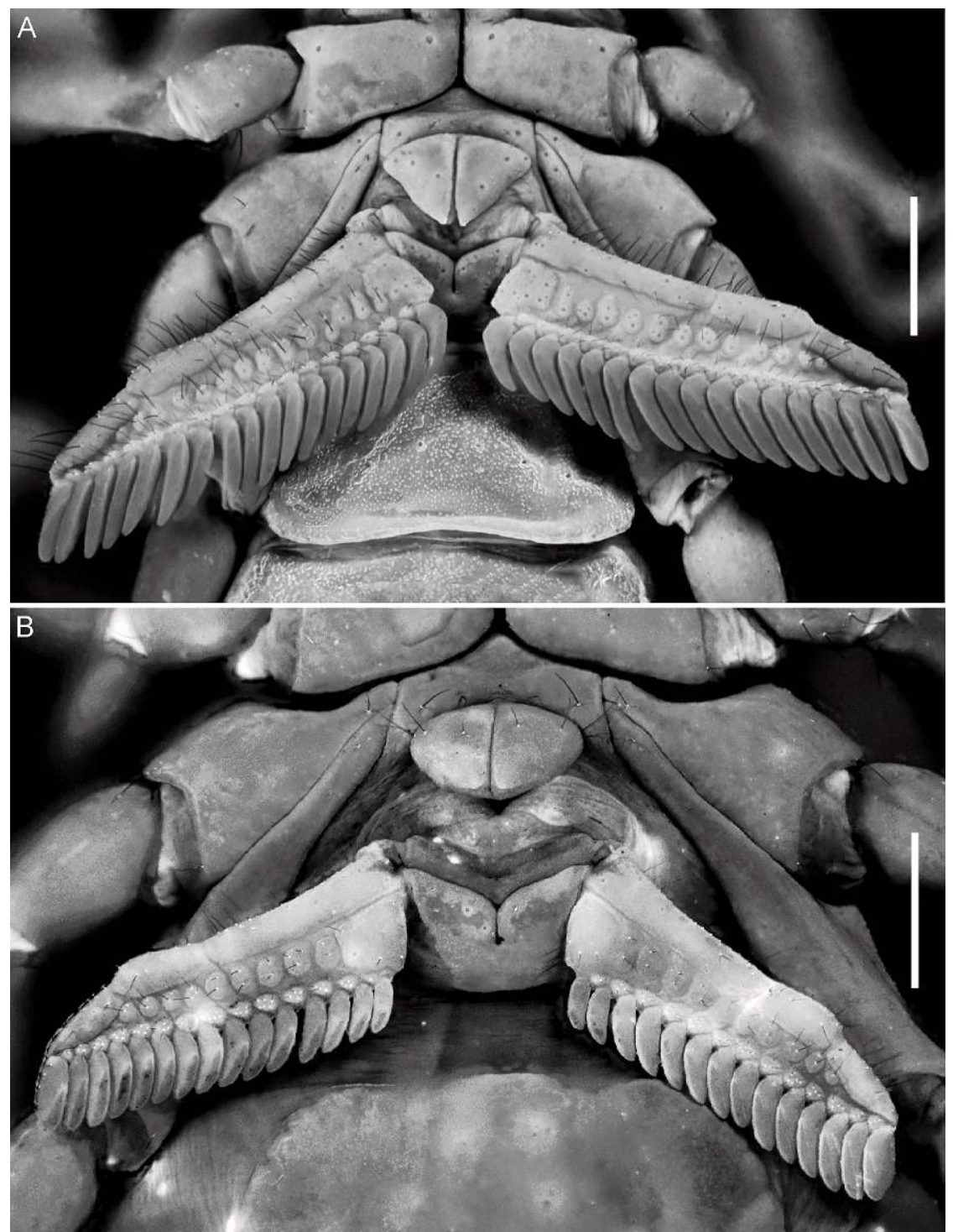

Fig. 9. Orobothriurus parvus Maury, 1976, sternum and pectines. A. $\delta$ (MHNC). B. + (MHNC). Scale bars $=1 \mathrm{~mm}$.

phytogeographic provinces (Cabrera and Willink, 1980). This species was collected in sympatry with another bothriurid, Brachistosternus montanus Roig Alsina, 1977.

\section{Orobothriurus ampay}

Ochoa and Acosta, 2003

Figures 4A, 11A, 12D, 17B, 22A, 25A, 27A, 52

Orobothriurus ampay Ochoa and Acosta, 2003: 2-

6, figs. 1-14; Ochoa, 2004a: 43, 52, 54, 73, figs.

$1,2,21$, table 1; 2005: 55, figs. 7,9 , table 2 .
Type Material: PerU: Apurímac Department: Abancay Province: Holotype $\hat{\sigma}$ (MUSM), Tamburco, Sector Arapato, Santuario Nacional Ampay, $13^{\circ} 35^{\prime} \mathrm{S} 72^{\circ} 52^{\prime} \mathrm{W}$, 3580 m, 25.viii.1998, R. Aimituma. Paratypes: Santuario Nacional Ampay, Bosque

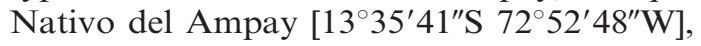
3100-3300 m, 26.viii.1998, J.C. Chaparro and J.A. Ochoa, 2 ㅇ (MHNC), 1 ㅇ (CDA 088), 1 \& (MACN-Ar 10039); Santuario Nacional Ampay, Ccorhuani [ca. 13 35'S 

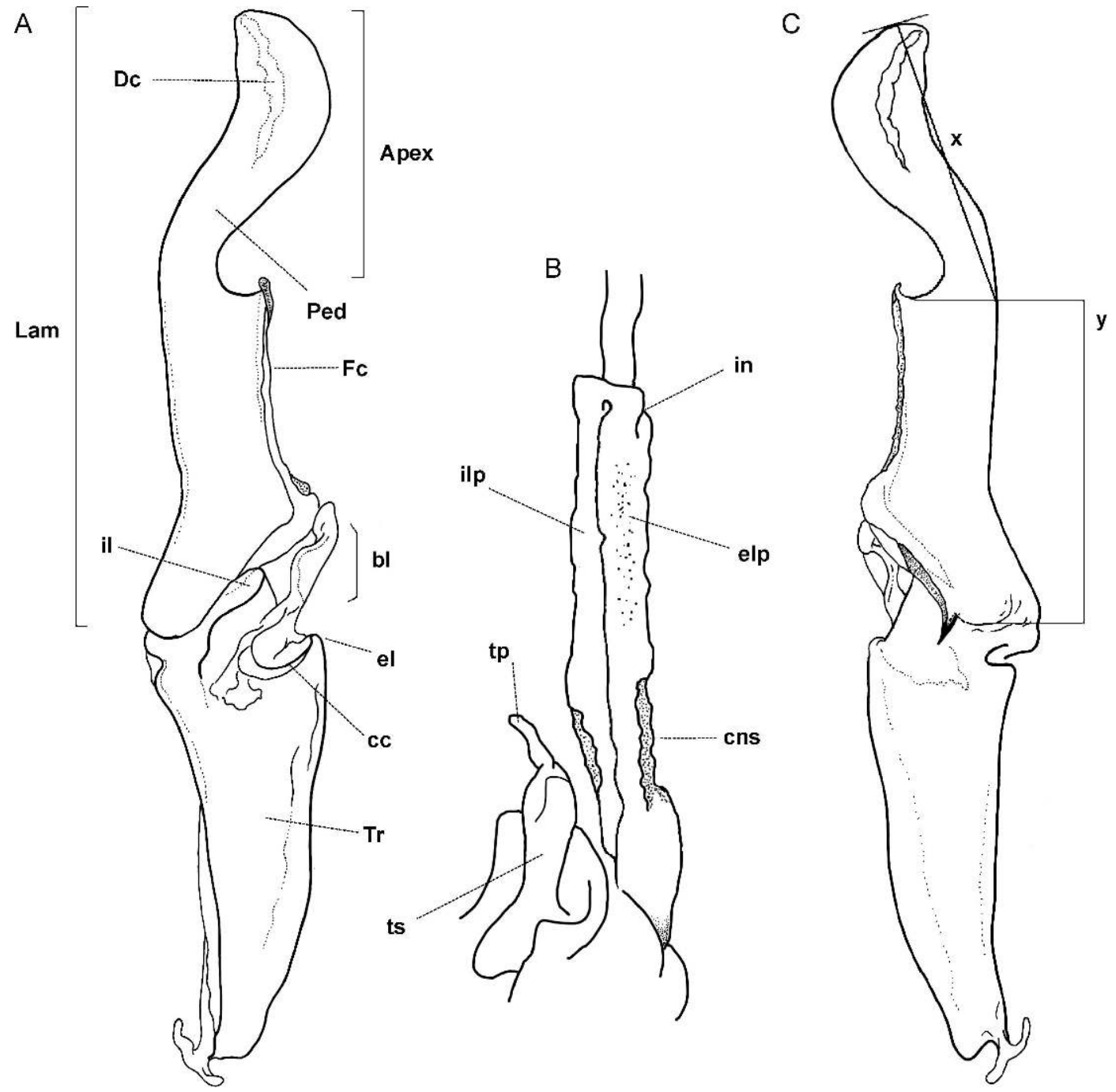

Fig. 10. Orobothriurus Maury, 1976. Sinistral hemispermatophore showing morphology and measurements. A. Ental aspect. B. Dorsal aspect. C. Ectal aspect. Annotations: basal lobe (bl); capsular concavity (cc); constriction (cns); distal crest (Dc); external lobe (el); external lateral projection (elp); frontal crest (Fc); internal lobe (il); internal lateral projection (ilp); incision (in); Lamina (Lam); pedicel (Ped); terminal process (tp); trunk (Tr); tortuous stem (ts); apex length (x); length of basal portion of lamina (y).

$\left.72^{\circ} 52^{\prime} \mathrm{W}\right], 3280 \mathrm{~m}, 18 . i x .1998, \mathrm{R}$. Aimituma, 1 우 (MUSM).

New ReCords: PERU: Apurímac Department: Abancay Province: Santuario Nacional Ampay, Bosque Nativo del Ampay, $13^{\circ} 35^{\prime} \mathrm{S}$ $72^{\circ} 52^{\prime} \mathrm{W}, 3200 \mathrm{~m}, 17 . v i i .2000$, J.A. Ochoa, in Podocarpus glomeratus forest, 1 \& (AMNH [LP 1918]).

DiAGNOSIS: Orobothriurus ampay differs from all other species in the genus by its well- developed pigmentation pattern. The tergites of this species are entirely, densely pigmented (fig. 12D) and the paired VL stripes contiguous with the VM stripe posteriorly on metasomal segments I-V (fig. 11A) whereas, in other species, tergites I-VI each possess two lateral spots delimiting an unpigmented median stripe along the mesosoma (fig. 13EG) and the paired VL stripes of the metasomal segments are not contiguous with the VM 
A

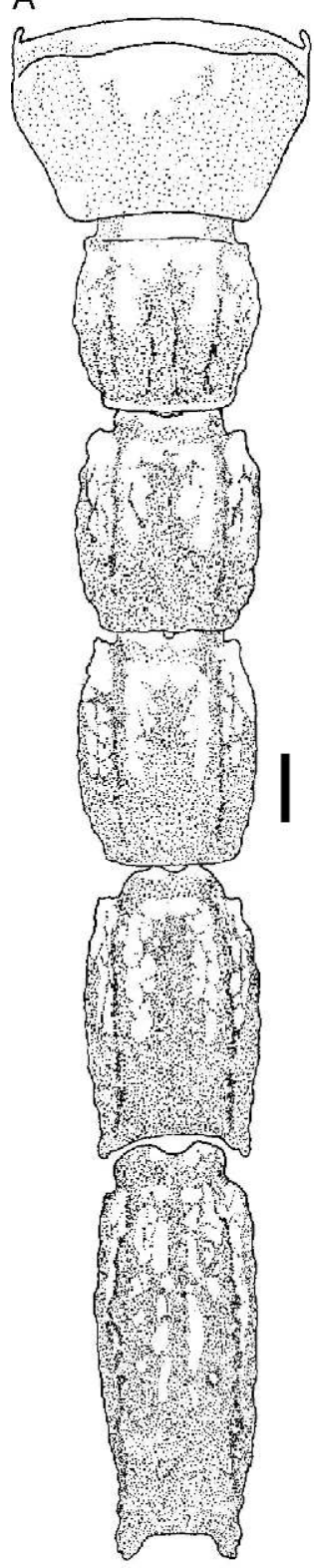

B
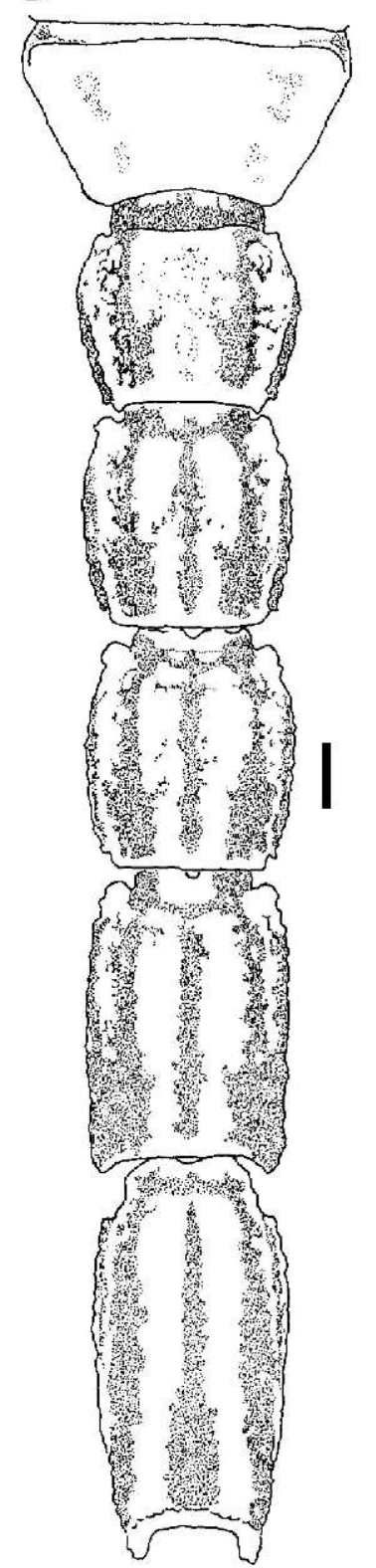

C
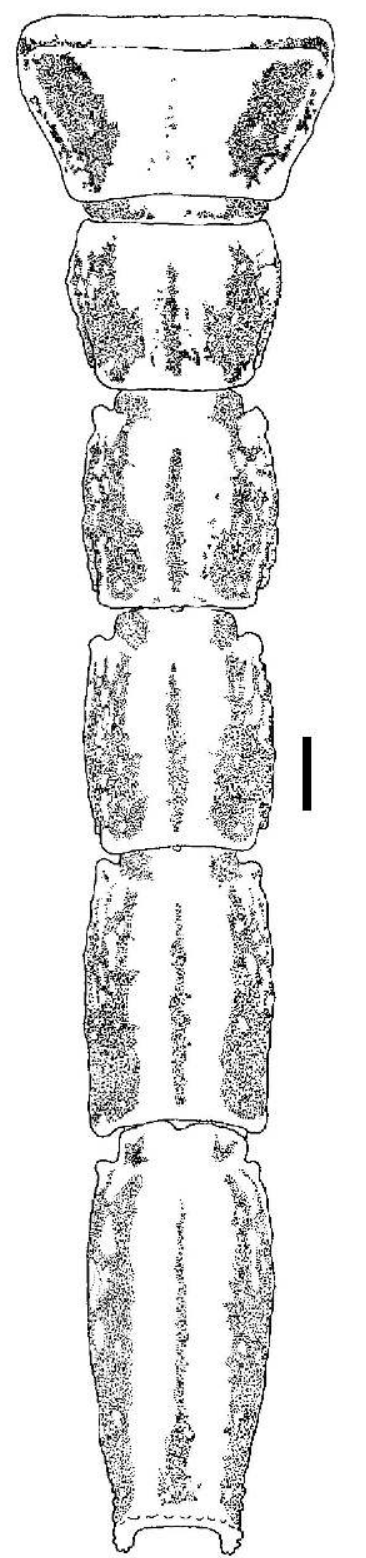

D

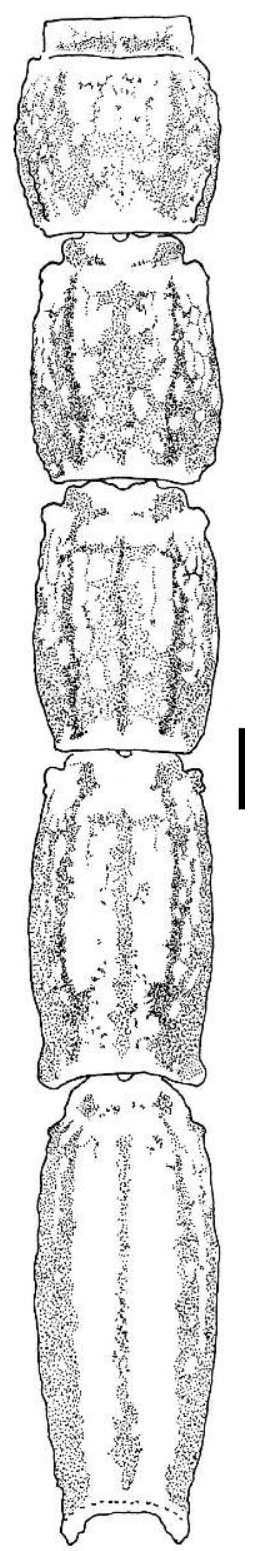

Fig. 11. Orobothriurus Maury, 1976, sternite VII and metasomal segments I-V, ventral aspect, showing pigmentation pattern. A. Orobothriurus ampay Ochoa and Acosta, 2003, allotype $q$ (MUSM). B. Orobothriurus curvidigitus (Kraepelin, 1911), $q$ (MHNC). C. Orobothriurus huascaran, n. sp., paratype $q$ (MHNC). D. Orobothriurus atiquipa Ochoa and Acosta, 2002, of paratype (MHNC). Scale bars $=1 \mathrm{~mm}$.

stripe posteriorly, at least on segments IV and V (figs. 11B-D, 13A, D). Orobothriurus ampay may be further distinguished on the basis of metasomal carination, trichobothriotaxy and pedipalp chela ornamentation. The VSM carinae, present on metasomal segment IV in $O$. ampay (fig. 17B), are absent in other species of Orobothriurus (fig. 17A). The angle formed between pedipalp chela trichobothria $e b-E t_{5}-E t_{4}$ is less than $90^{\circ}$ in $O$. ampay 
A

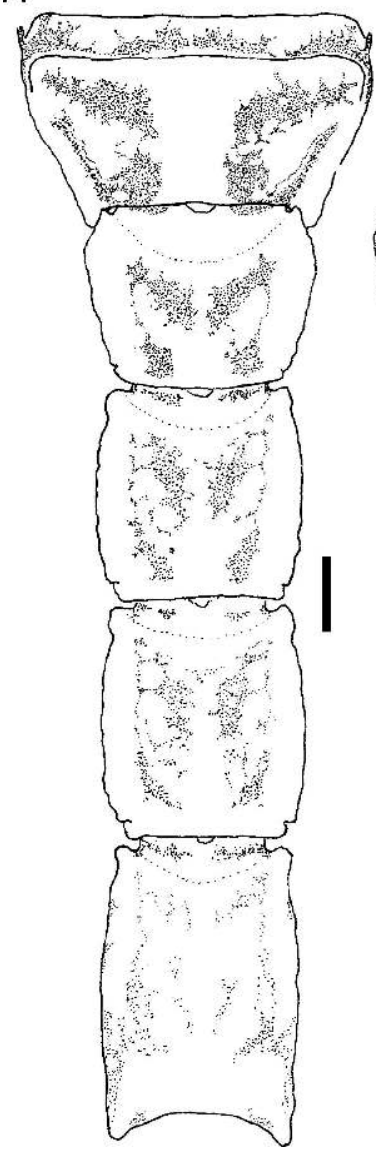

B

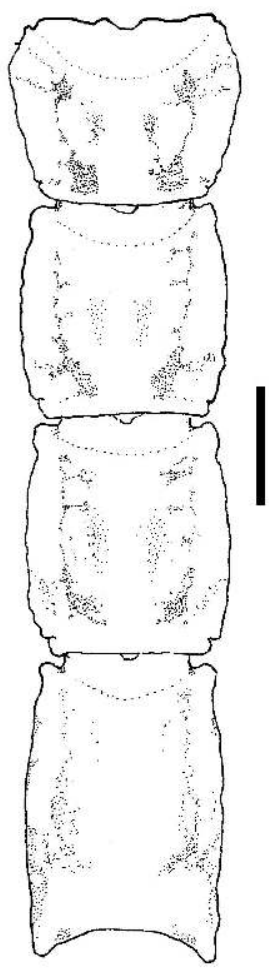

C

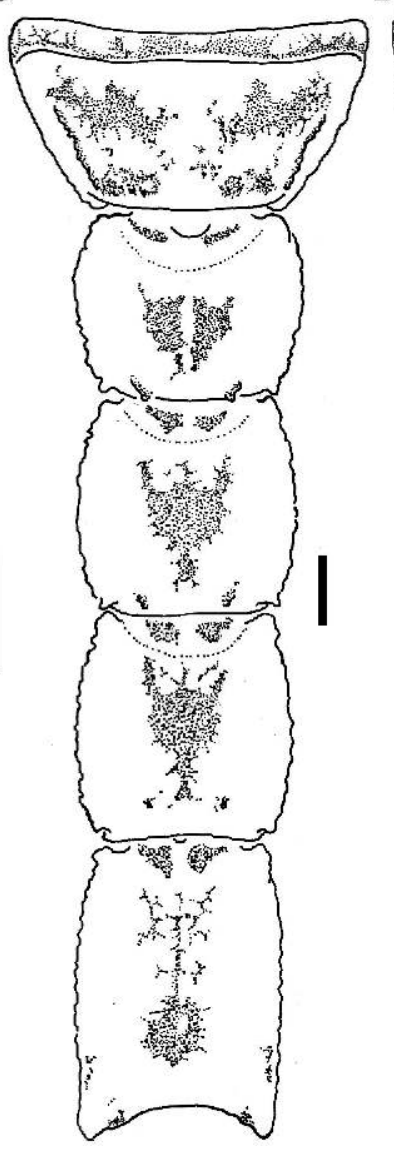

D

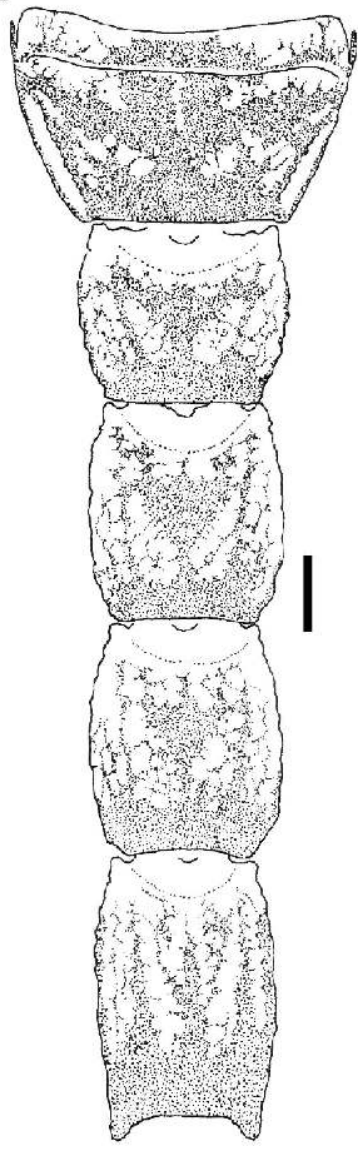

Fig. 12. Orobothriurus Maury, 1976, tergite VII (A, C, D only) and metasomal segments I-IV, dorsal aspect, showing pigmentation pattern. A. Orobothriurus huascaran, n. sp., paratype $q$ (MHNC). B. Orobothriurus parvus Maury, 1976, \& (MHNC). C. Orobothriurus curvidigitus (Kraepelin, 1911), i (MHNC). D. Orobothriurus ampay Ochoa and Acosta, 2003, allotype + (MUSM). Scale bars $=1 \mathrm{~mm}$.

(fig. 25A), but greater than $90^{\circ}$ in other species (figs. 25B, D, 26B, C). The acuminate conical apophysis on the internal surface of the male pedipalp chela manus, observed in all other Orobothriurus species (except $O$. wawita, in which it is absent altogether), is reduced to a few granules in $O$. ampay. The hemispermatophore of $O$. ampay resembles that of $O$. parvus and $O$. wawita in possessing an elongated apex and a short frontal crest, which is less than half the length of the lamina. However, the ventral margin of the apex is inclined to the dorsal surface and curved distally in $O$. ampay (fig. 27A) and $O$. parvus (fig. 27B), but straight in $O$ wawita (fig. 27C). Finally, O. ampay possesses the lowest pectinal tooth count in the genus (12-15).

DISTRIBUTION: Orobothriurus ampay is known only from the Santuario Nacional Ampay, near Abancay in the Apurímac Department of southeastern Peru, at 3100 $3580 \mathrm{~m}$ (figs. 3E, 52).

ECOLOGY: Orobothriurus ampay appears to be endemic to an inter-Andean forest of Podocarpus glomeratus Don (Podocarpaceae) (fig. 3E). All known records of this species were collected inside the forest under stones on moist soil. No other scorpion species are known from this forest. The closest records are two other bothriurids, Brachistosternus peruvianus Piza, 1974, and Pachakutej iskay 
A

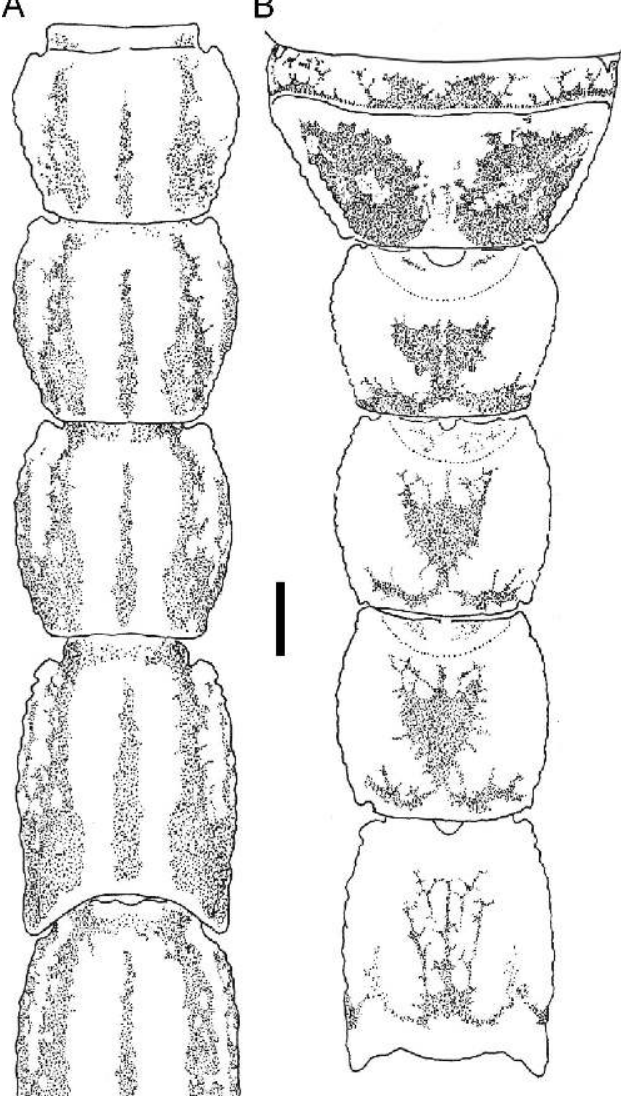

C

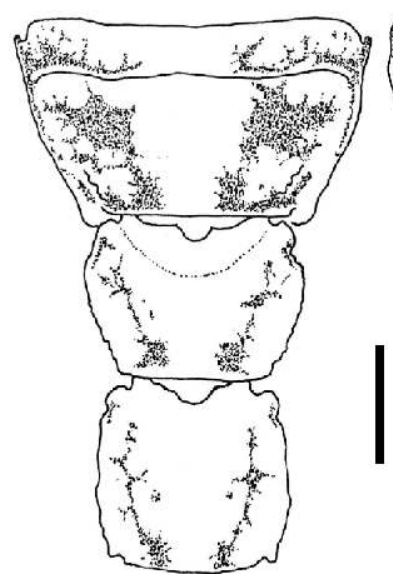

$\mathrm{F}$

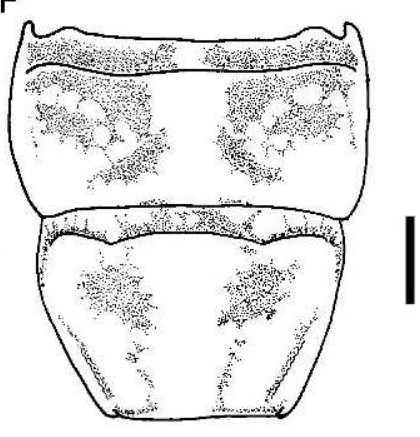

G

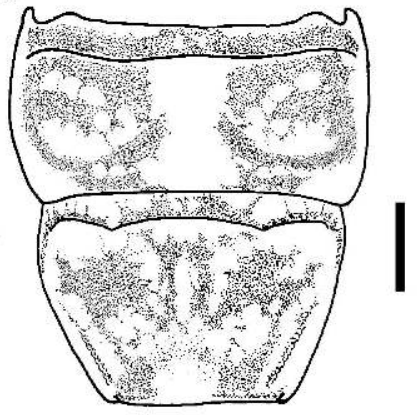

$\mathrm{D}$
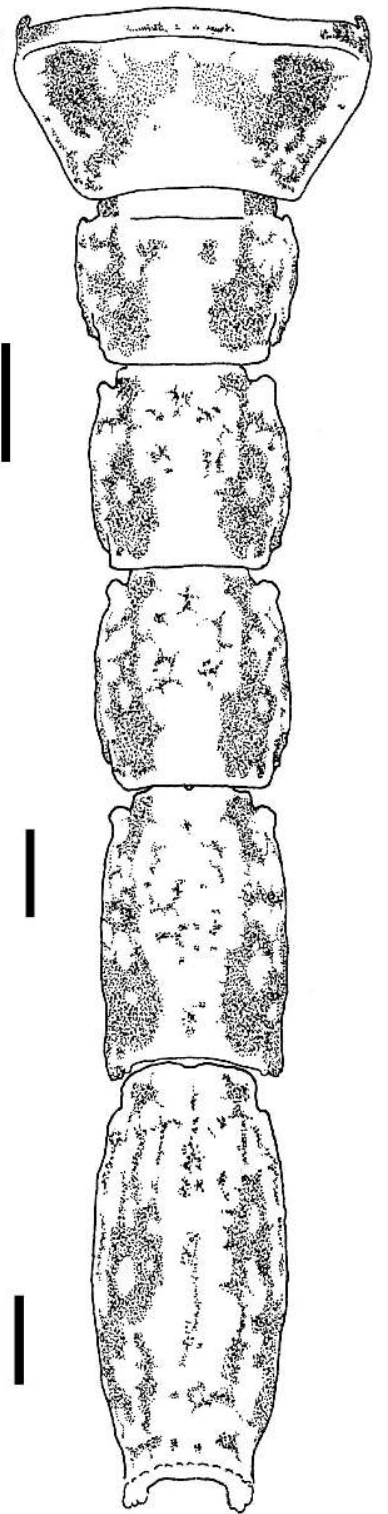

Fig. 13. Orobothriurus Maury, 1976, tergites, sternites and metasomal segments I-V, showing pigmentation pattern. A, B. Orobothriurus paessleri (Kraepelin, 1911), \& (MHNC), metasomal segments IV, ventral aspect (A), tergite VII and metasomal segments I-IV, dorsal aspect (B). C, D. Orobothriurus wawita Acosta and Ochoa, 2000, ㅇ (MHNC), tergite VII and metasomal segments I and II, dorsal aspect (C), sternite VII and metasomal segments I-V, ventral aspect (D). E. Orobothriurus curvidigitus (Kraepelin, 1911), \& (MHNC), tergite V, dorsal aspect. F. Orobothriurus alticola (Pocock, 1899), \& (MACN-Ar), tergites VI and VII, dorsal aspect. G. Orobothriurus grismadoi Ojanguren-Affilastro et al., 2009, tergites VI and VII, dorsal aspect. Scale bars $=1 \mathrm{~mm}$. 
(Acosta and Ochoa, 2001), and a buthid, Tityus footei Chamberlin, 1916, which inhabit an adjacent dry valley in Tamburco.

\section{Orobothriurus atiquipa}

Ochoa and Acosta, 2002

Figures 11D, 18A, 21A, 25D, 28A, 53

Orobothriurus atiquipa Ochoa and Acosta, 2002a: 99-102, figs. 1-9, table 1; Ojanguren Affilastro, 2003a: 121, fig. 14; Ochoa, 2004a: 43, 52, 55, 73, figs. $1,2,21$, table 1; 2005: 55, figs. 7, 9, table 2; Rein, 2007: 5.

Orobothriurus aff. paessleri: Lourenço and Dastych, 2001: 54 [probable misidentification: specimens from Chala].

Orobothriurus paessleri: Lourenço and Dastych, 2001: 54 [probable misidentification: specimens from Atico and Road between Chala and Cháparra].

Type Material: PERU: Arequipa Department: Caraveli Province: Holotype ô (MACN-Ar 10010), paratype $\delta$ (MHNC), Lomas Atiquipa, Cerro Lloque, $15^{\circ} 45^{\prime} \mathrm{S}$ $74^{\circ} 22^{\prime} \mathrm{W}, 950$ m, 13.ix.1999, H. Zeballos and R. Gutiérrez.

New Records: PERU: Arequipa Department: Caraveli Province: Lomas Atiquipa, Sector Conchara, $15^{\circ} 46^{\prime} 16^{\prime \prime} \mathrm{S} 74^{\circ} 22^{\prime} 42^{\prime \prime} \mathrm{W}$, $750 \mathrm{~m}$, 6.iii.2004, J.L. Velasquez and J.A. Ochoa, 3 s, 3 juv. (MHNC), 2 juv. (AMNH [LP 3056]).

DiAGNOSIS: Orobothriurus atiquipa may be distinguished from all other species of the genus by means of the telotarsal setation of the legs and the granulation on the ventral surface of metasomal segment $\mathrm{V}$. In $O$. atiquipa, the telotarsi of legs III and IV each possess $3 / 4$ spiniform macrosetae in the proand retroventral rows, and the VSM and VM carinae are not discernible from the dense granulation on the ventral surface of segment $\mathrm{V}$ (fig. 21A) whereas, in other species of Orobothriurus, the telotarsi of legs III and IV each possess $3 / 3$ spiniform macrosetae in the pro- and retroventral rows, and the $\mathrm{VM}$ and VL carinae are well defined on segment $\mathrm{V}$ (figs. 20A, D, E, 21D). Additionally, the hemispermatophore of $O$. atiquipa is proportionally longer than that of all other species. This species possesses the most elongated frontal crest in the genus (fig. 28A).

DISTRIBUTION: Orobothriurus atiquipa is known only from the type locality in northern Arequipa Department, southern Peru, at 750-950 m (figs. 2D, 53).

ECOLOGY: Lomas biotopes are isolated patches of green vegetation on hillsides below $1000 \mathrm{~m}$, surrounded by hyperarid desert, along the western coast of southern Peru and northern Chile (fig. 2D). Climatic patterns produce fog zones that allow plant communities to exist in areas where the rainfall is very low. The flora and fauna of Lomas have closer affinities with that of the high Andean peaks than the surrounding desert biota (Herrera, 1930; Péfaur, 1981; Ochoa, 2005). The vegetation in the habitat of $O$. atiquipa is characterized by shrubs, herbaceous plants, and trees like Myrcianthes ferreyrae (McVaugh) McVaugh (Myrtaceae), Caesalpinia spinosa (Molina) Kuntze (Fabaceae), Acacia macracantha Humboldt and Bonpland ex Willdenow (Fabaceae), and Carica candicans A. Gray (Caricaceae). An iurid in the genus Hadruroides was recorded in sympatry with O. atiquipa (Ochoa and Prendini, 2010).

REMARKS: Specimens from three localities (Atico, Chala and Road between Chala and Cháparra) in the Arequipa Department, Peru, were listed under $O$. paessleri and " $O$. aff. paessleri" by Lourenço and Dastych (2001: 54), who noted that the specimens from Chala are "possibly a new species." Although we have not examined these specimens, they are probably conspecific with $O$. atiquipa, not $O$. paessleri, based on the known distribution of this species.

Orobothriurus calchaqui, n. sp.

Figures 14A, 18B, 21D, 23B, 24A, 29-31, $32 \mathrm{~A}, \mathrm{~B}, 36 \mathrm{~K}-\mathrm{O}, 54$; table 3

Orobothriurus alticola: Maury, 1976: 18 (part) [misidentification].

Type Material: ARGENTINA: Tucumán Province: Tafi del Valle Department: Holotype ô (MACN-Ar), El Infiernillo (Tafí del Valle), 26 44' $13.3^{\prime \prime} \mathrm{S} 65^{\circ} 45^{\prime} 51.2^{\prime \prime} \mathrm{W}, 2700 \mathrm{~m}$, 30.x.2004, A. Ojanguren Affilastro and L. Compagnucci. Paratypes: same data, $20 \hat{\delta}, 2$ ㅇ (MACN-Ar), 2 के (AMNH), 2 के (AMNH [LP 5195]), 2 के (LBRE), 2 के (MHNC); Cumbres Calchaquies, Huaca Huasi, $4250 \mathrm{~m}$, E. Domínguez, 1 (MACN-Ar); Vaca Huasi, 4300 m, 16.xi.1974, S. Hallow, 1 ㅇ (MACN-Ar). 

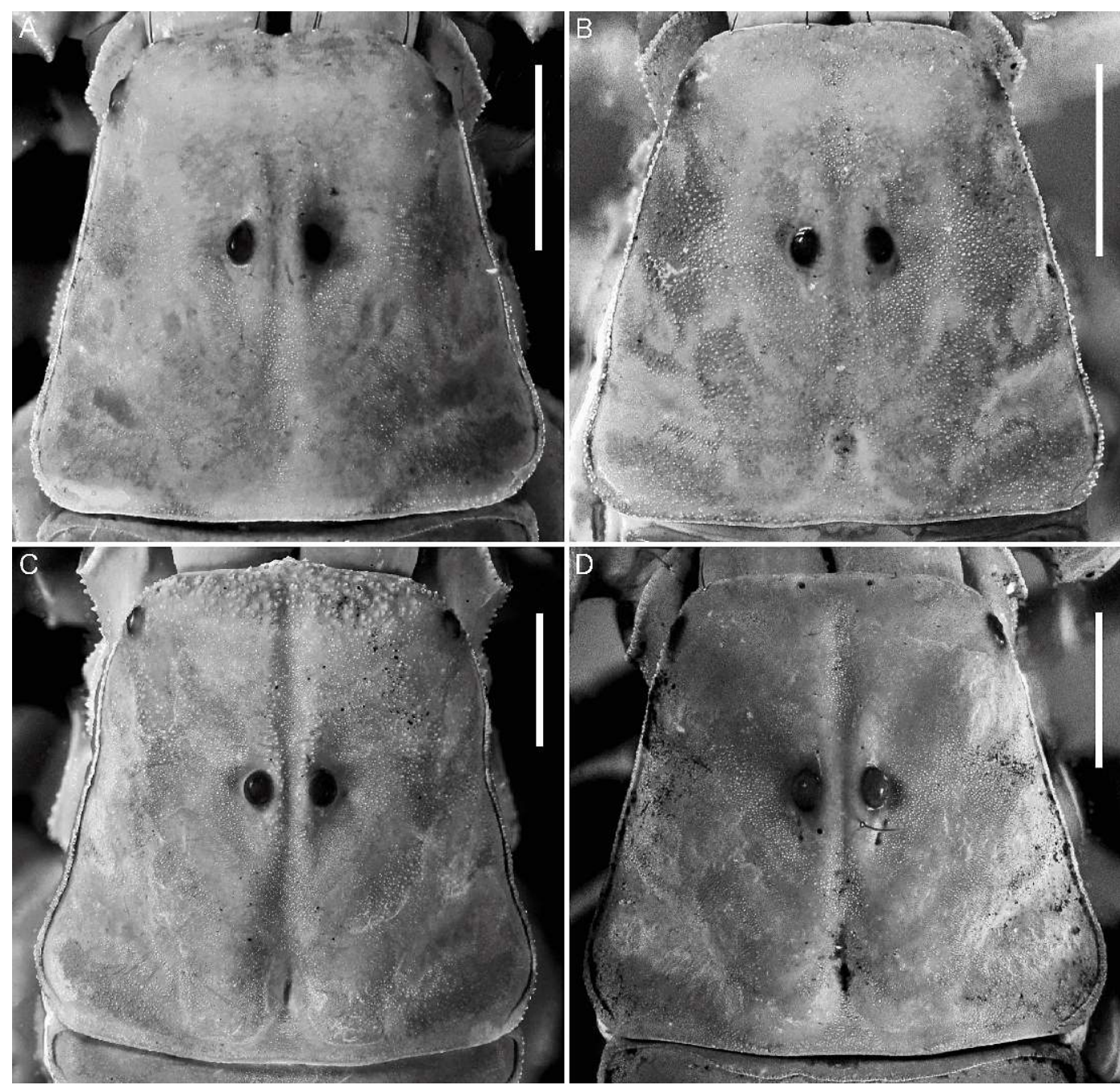

Fig. 14. Orobothriurus Maury, 1976, carapace, dorsal aspect. A. Orobothriurus calchaqui, n. sp., paratype of (MACN-Ar). B. Orobothriurus compagnuccii, n. sp., paratype of (MACN-Ar). C. Orobothriurus curvidigitus, \& (MHNC). D. Orobothriurus huascaran, n. sp., paratype $\delta$ (MACN-Ar). Scale bars $=1 \mathrm{~mm}$.

ETYMOLOGY: The specific name is a noun in apposition referring to the Cumbres Calchaquies mountain range in the Andes, where this species occurs.

Diagnosis: Orobothriurus calchaqui is most closely related to $O$. famatina (fig. 5). The two species can be separated by a combination of characters, several of which overlap in some specimens. Orobothriurus calchaqui possesses two or three ML macrosetae on metasomal segment IV, and $70 \%$ of specimens possess one DL macroseta on segment III (absent in 30\%), whereas $O$. famatina possesses one ML macroseta on segment IV and only $10 \%$ of specimens possess one DL macroseta on segment III (absent in 90\%). There are also differences in the trichobothrial pattern. Pedipalpal chela trichobothria $d b$ and $E t_{3}$ are always located proximal to Est in O. calchaqui (fig. 31C) whereas, in $O$. famatina, $d b$ is located in the same axis as $E t_{3}$ (in $70 \%$ of the specimens) or 


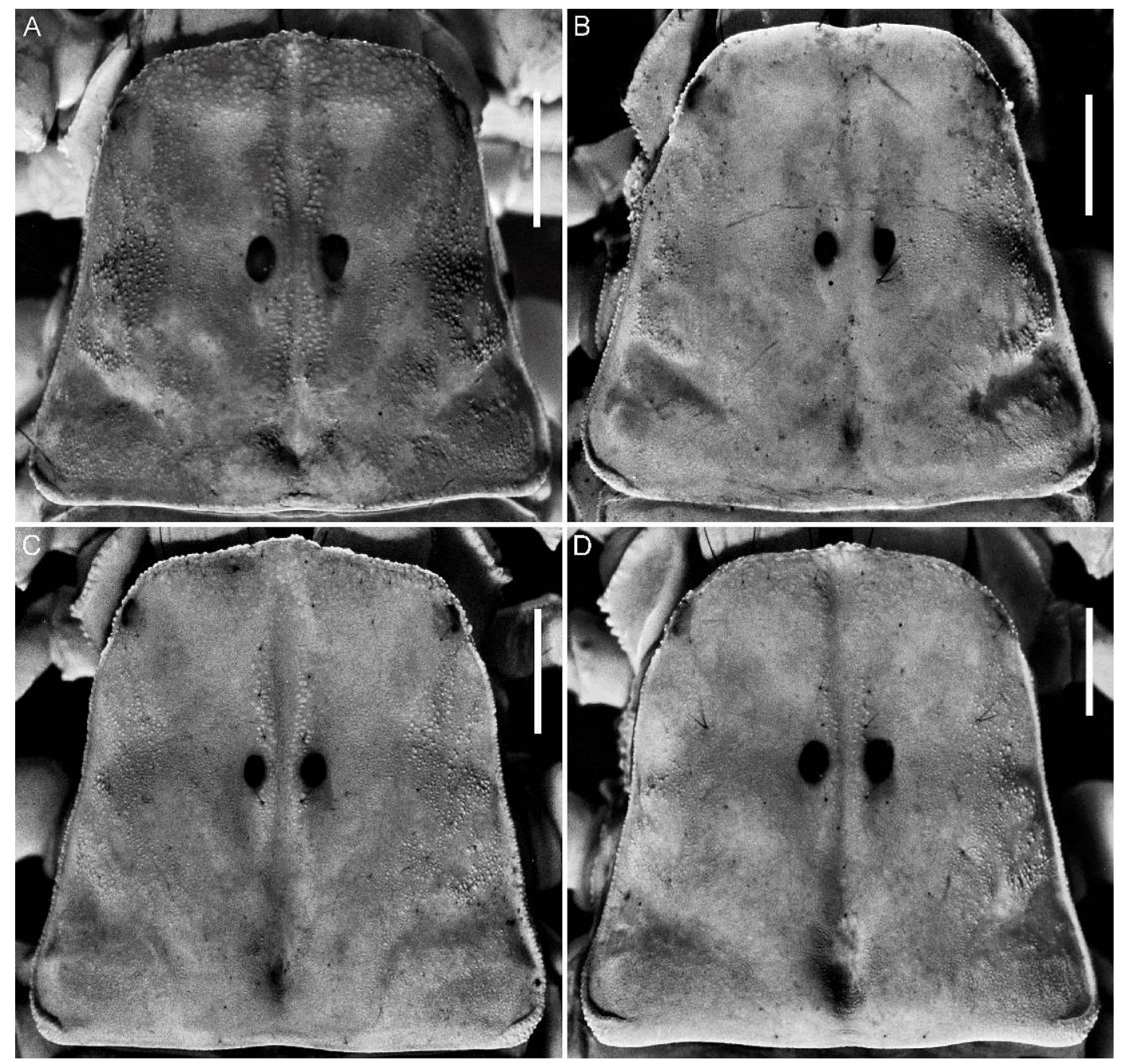

Fig. 15. Orobothriurus Maury, 1976, carapace, dorsal aspect. A. Orobothriurus paessleri (Kraepelin, 1911), $\delta$ (CDA 186). B. Orobothriurus alticola (Pocock, 1899), ô (AMNH). C. Orobothriurus quewerukana, n. sp., paratype $\delta$ (AMNH). D. Orobothriurus tamarugal, n. sp., holotype ô (MACN-Ar). Scale bars $=1 \mathrm{~mm}$.

slightly distal to it (30\%). Pedipalp patella trichobothrium $\mathrm{em}_{2}$ is located proximal to $e m_{1}$ in $80 \%$ of the specimens of $O$. calchaqui (fig. 30C), but in the same axis as, or distal to $e m_{1}$ in $70 \%$ of the specimens of $O$. famatina. There are also slight differences in the shape of the hemispermatophore in most specimens. The pedicel of the apex is usually narrower and the angle formed by the apex with the rest of the distal lamina usually greater in $O$. calchaqui than $O$. famatina (fig. $36 \mathrm{~F}-\mathrm{H}, \mathrm{K}-\mathrm{M}$ ). However, the hemispermatophore of some specimens of $O$. calchaqui is indistinguishable from that of $O$. famatina (fig. $36 \mathrm{~N}, \mathrm{O}$ ).

DESCRIPTION: Based on holotype $\delta$ and paratypes. Measurements of holotype $\hat{\delta}$ and paratype $q$ recorded in table 3 .

Total length: ô, 23-30 mm $(n=10$, mean $=25.9 \mathrm{~mm})$; + , $33.5-36 \mathrm{~mm}(n=4$, mean $=$ $34.45 \mathrm{~mm}$ ).

Color: General color yellowish with dark brown spots (fig. 29). Carapace, anterior margin faintly pigmented; lateral margins with two large spots medially and posteriorly, remaining area with reticulate pigmentation; 

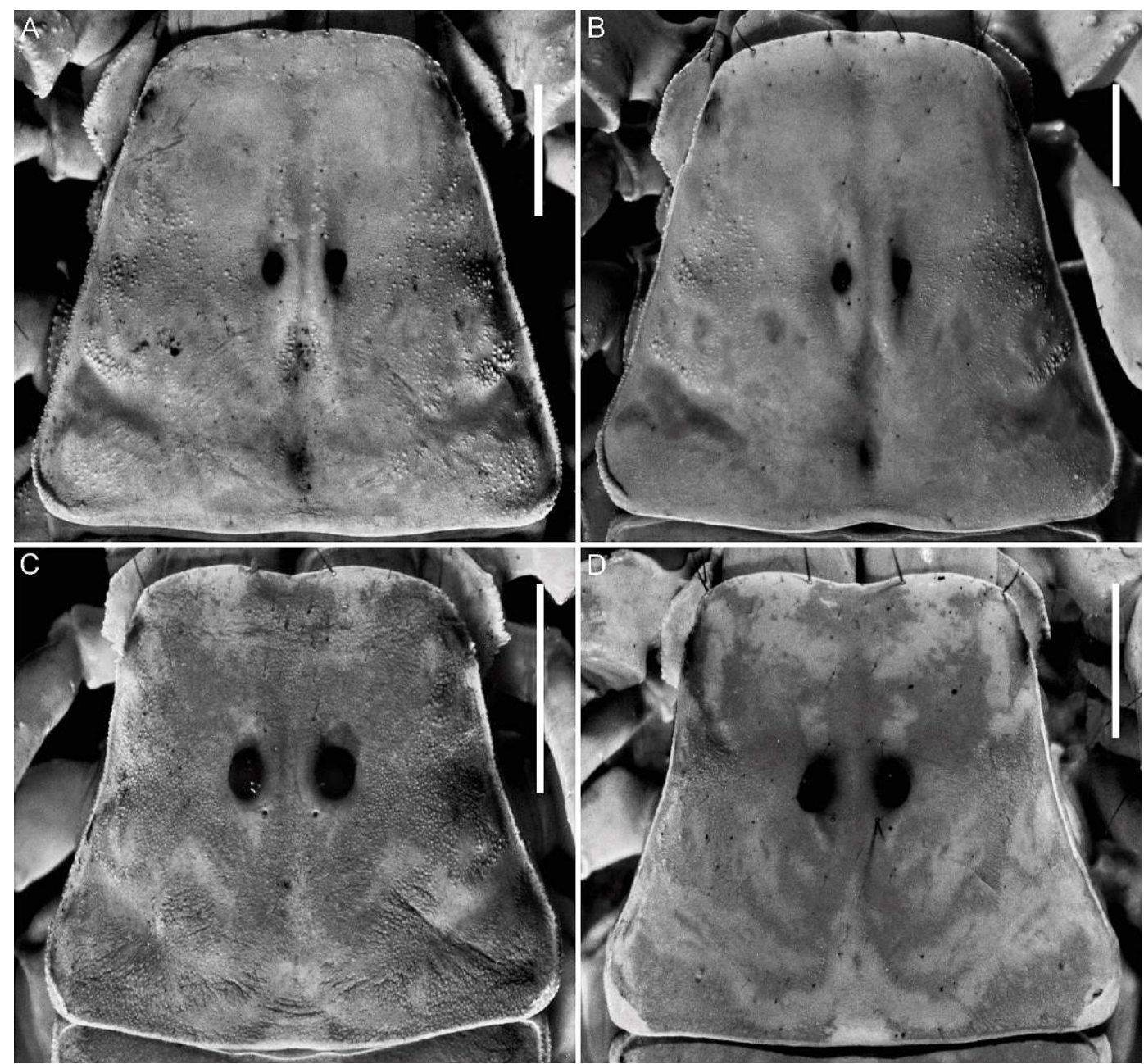

Fig. 16. Orobothriurus Maury, 1976, carapace, dorsal aspect. A, B. Orobothriurus ramirezi, n. sp. A. Holotype of (MACN-Ar). B. Paratype $q$ (MACN-Ar). C, D. Orobothriurus wawita Acosta and Ochoa, 2000. C. Paratype ô (CDA 019). D. Paratype + (CDA 019). Scale bars $=1 \mathrm{~mm}$.

median ocular tubercle and lateral ocelli dark brown to black; posterior half of anteromedian longitudinal sulcus, median ocular tubercle, and postocular sulcus pigmented. Chelicerae, distal surface of manus, and movable finger with reticulate pigmentation. Pedipalp coxa and trochanter faintly pigmented; femur densely pigmented near articulation with patella; patella densely pigmented near articulations; chela manus with six complete longitudinal stripes along carinae, contiguous at base of movable finger; fingers and articulation of fingers pigmented. Legs, femur, patella, tibia, and basitarsus faintly pigmented, especially near articulations and along dorsal margin. Tergites I-VI each with two dark spots sublaterally along almost entire margin, broader near anterior margin, delimiting broad, unpigmented median stripe (fig. 29A, B); VII with four dark spots, two larger spots posterolaterally, occupying area between dorsolateral carinae and external margins of sclerite, and two small dark triangular spots submedially, extending along submedian carinae, delimiting unpigmented median stripe. Sternum, genital opercula and pectines unpigmented. Sternites III-VI usually unpigmented, but lateral margins of segments V and VI faintly pigmented in some specimens; VII with two narrow dark stripes 


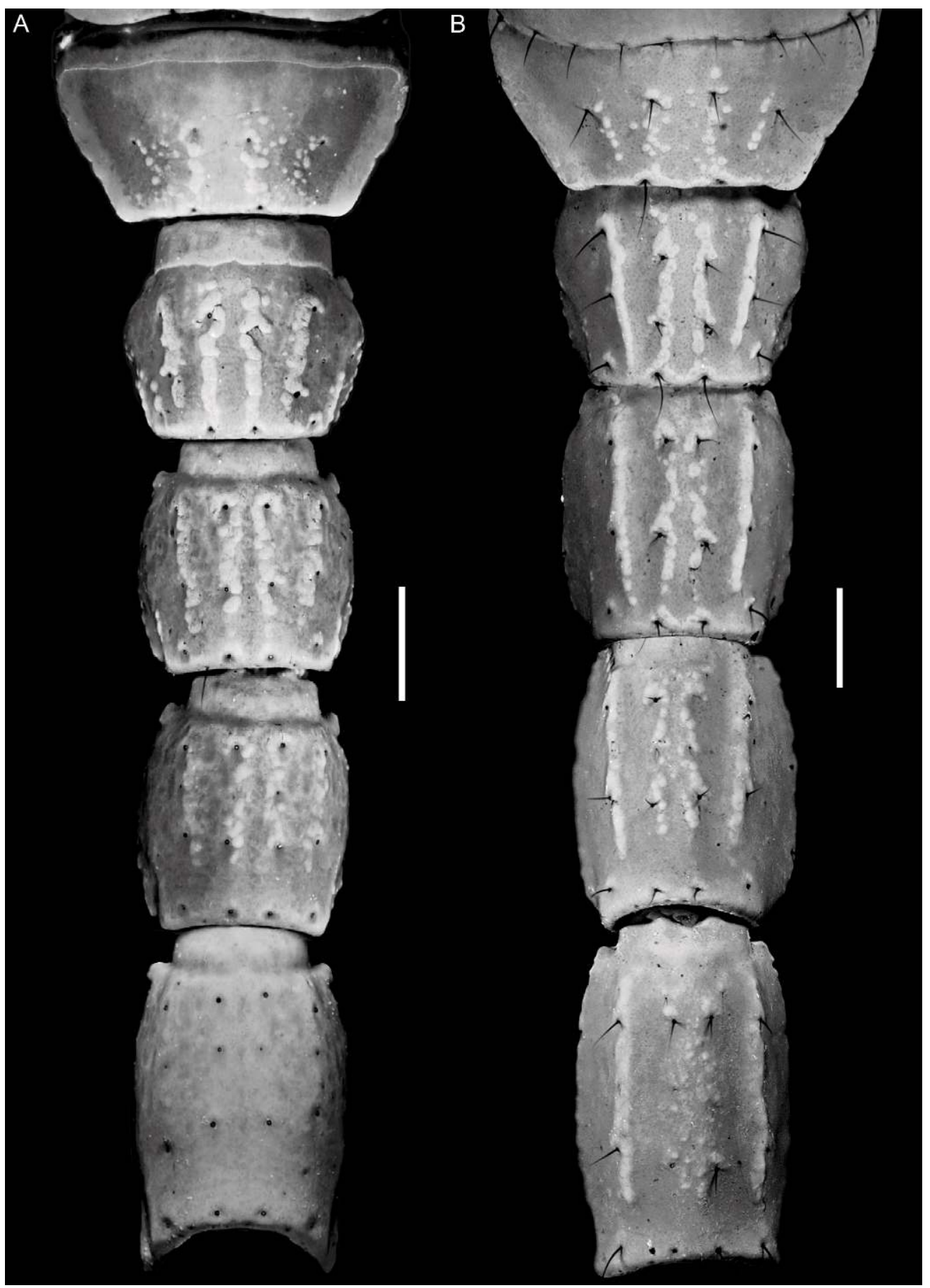

Fig. 17. Orobothriurus Maury, 1976, sternite VII and metasomal segments I-IV, ventral aspect. A. Orobothriurus parvus Maury, 1976, + (MHNC). B. Orobothriurus ampay Ochoa and Acosta, 2003, paratype $q$ (MHNC). Scale bars $=1 \mathrm{~mm}$. 

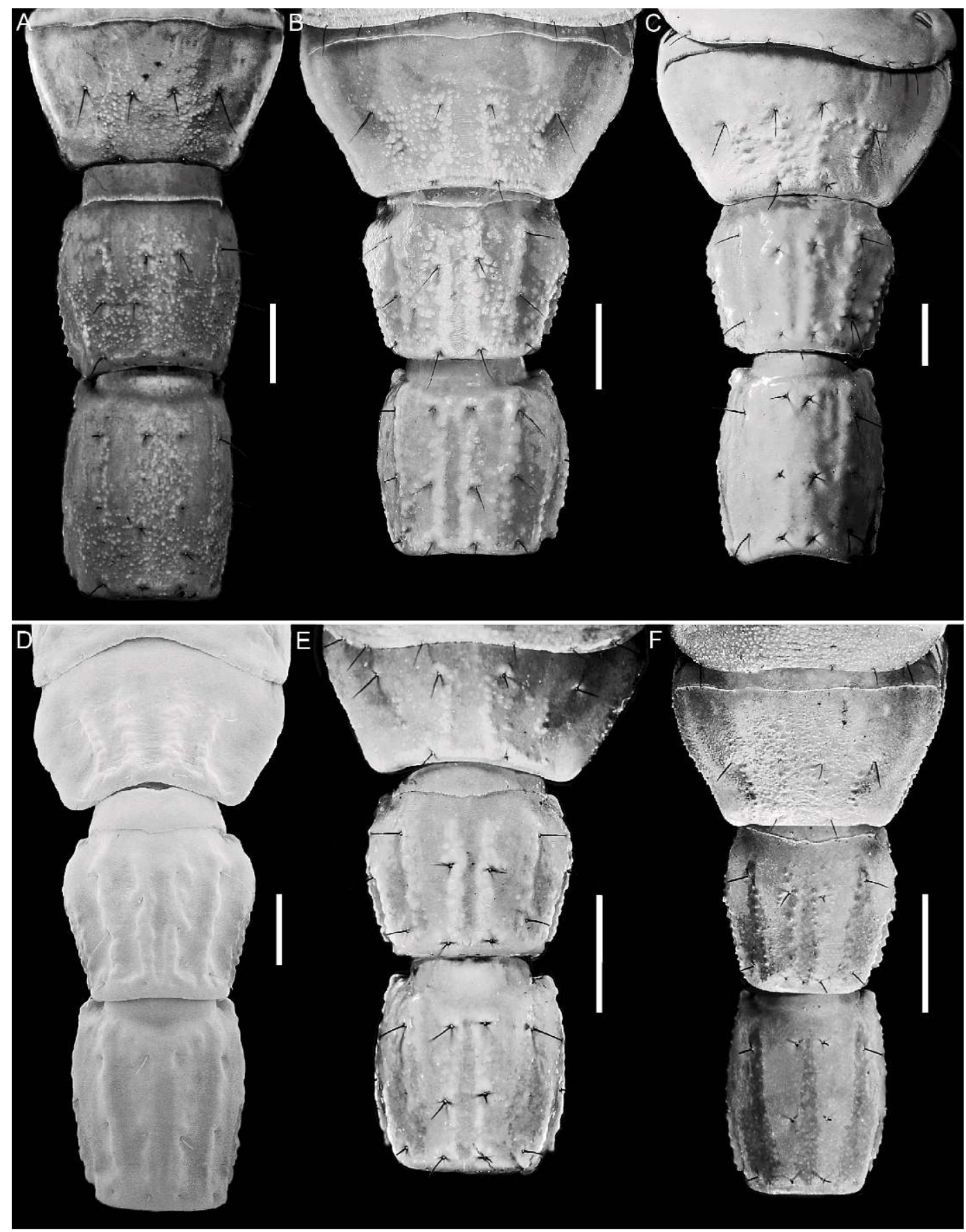

Fig. 18. Orobothriurus Maury, 1976, sternite VII and metasomal segments I and II, ventral aspect. A. Orobothriurus atiquipa Ochoa and Acosta, 2003, paratype \& (MHNC). B. Orobothriurus calchaqui, n. sp., paratype + (MACN-Ar). C. Orobothriurus ramirezi, n. sp., paratype + (MACN-Ar). D. Orobothriurus alticola (Pocock, 1899), \& (MACN-Ar). E, F. Orobothriurus compagnuccii, n. sp. E. Paratype $q$ (MACNAr). F. Paratype of (MACN-Ar). Scale bars $=1 \mathrm{~mm}$. 

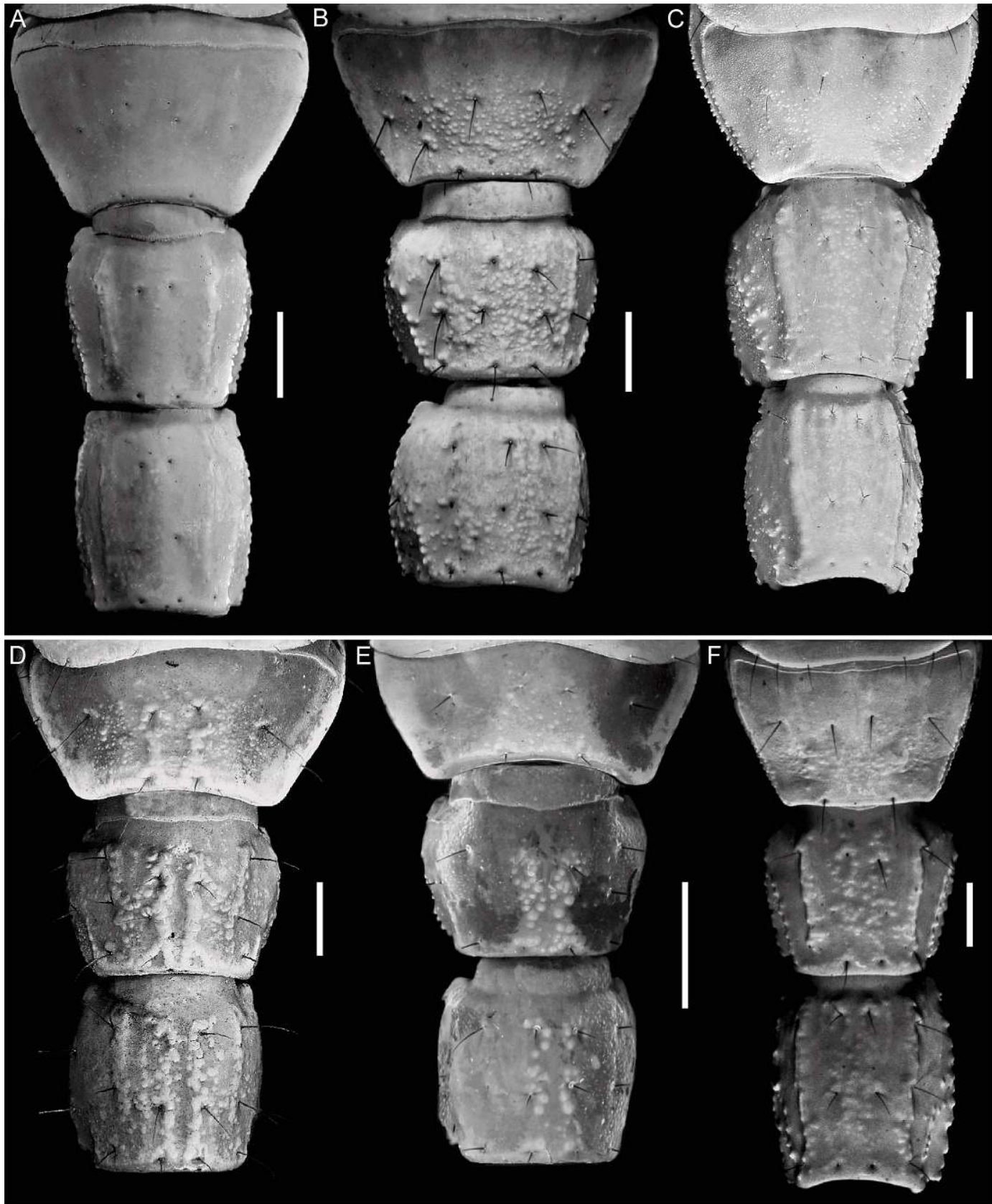

Fig. 19. Orobothriurus Maury, 1976, sternite VII and metasomal segments I and II, ventral aspect. A. Orobothriurus curvidigitus (Kraepelin, 1911), + (MHNC). B. Orobothriurus paessleri (Kraepelin, 1911), + (MHNC). C. Orobothriurus quewerukana, n. sp., paratype \& (MHNC). D. Orobothriurus huascaran, n. sp., paratype + (MACN-Ar). E. Orobothriurus wawita Acosta and Ochoa, 2000, paratype + (MHNC). F. Orobothriurus tamarugal, n. sp., holotype $\delta$ (MACN-Ar). Scale bars $=1 \mathrm{~mm}$. 


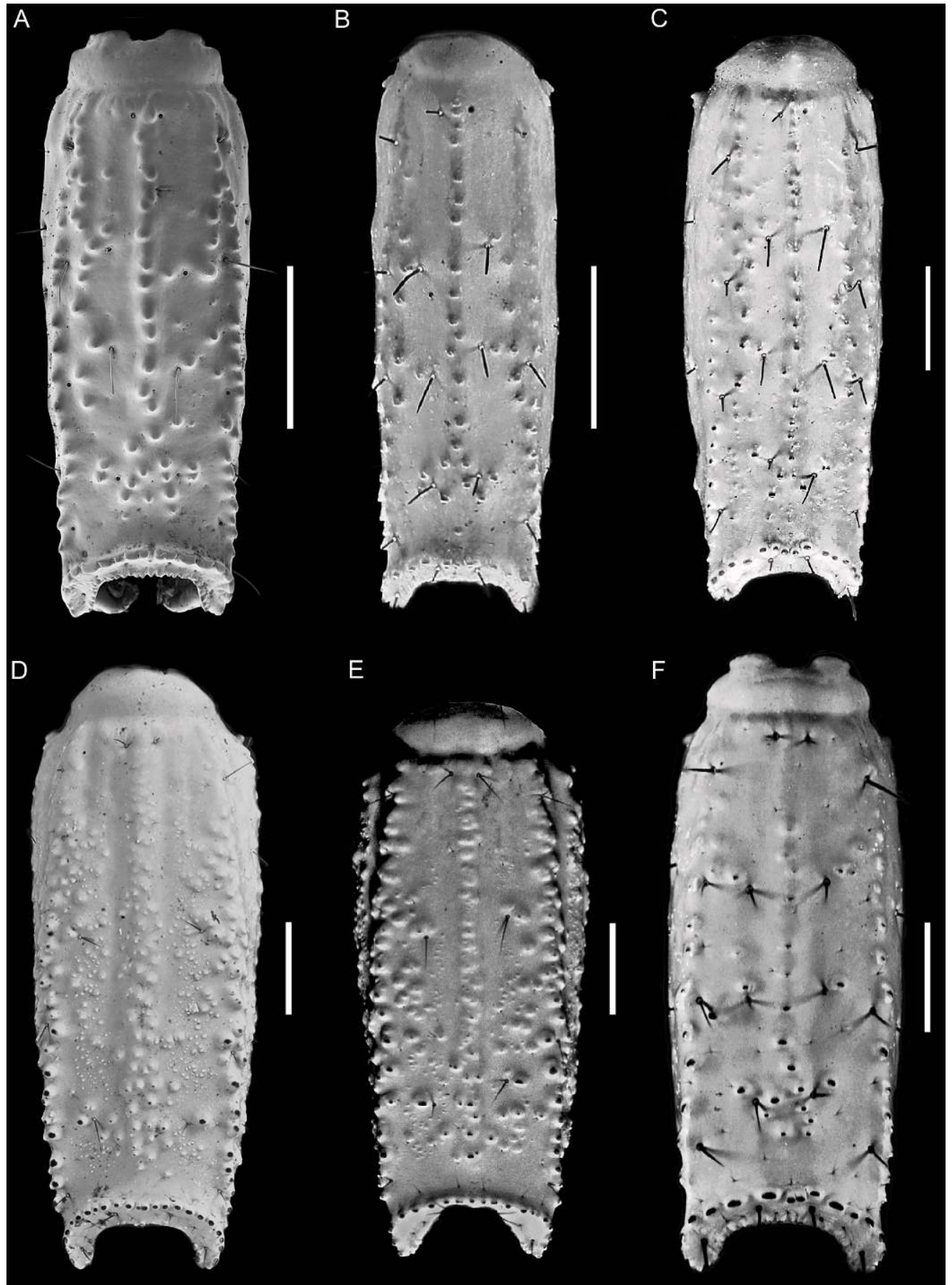

Fig. 20. Orobothriurus Maury, 1976, metasomal segment V, ventral aspect. A. Orobothriurus alticola (Pocock, 1899), ㅇ (MACN-Ar). B. Orobothriurus compagnuccii, n. sp., paratype $\hat{\delta}$ (MACN-Ar). C. Orobothriurus ramirezi, n. sp., paratype $\delta$ (MACN-Ar). D. Orobothriurus quewerukana, n. sp., paratype $\delta$ (MHNC). E. Orobothriurus tamarugal, n. sp., holotype कै (MACN-Ar). F. O. ramirezi, n. sp., paratype + (MACN-Ar). Scale bars $=1 \mathrm{~mm}$. 

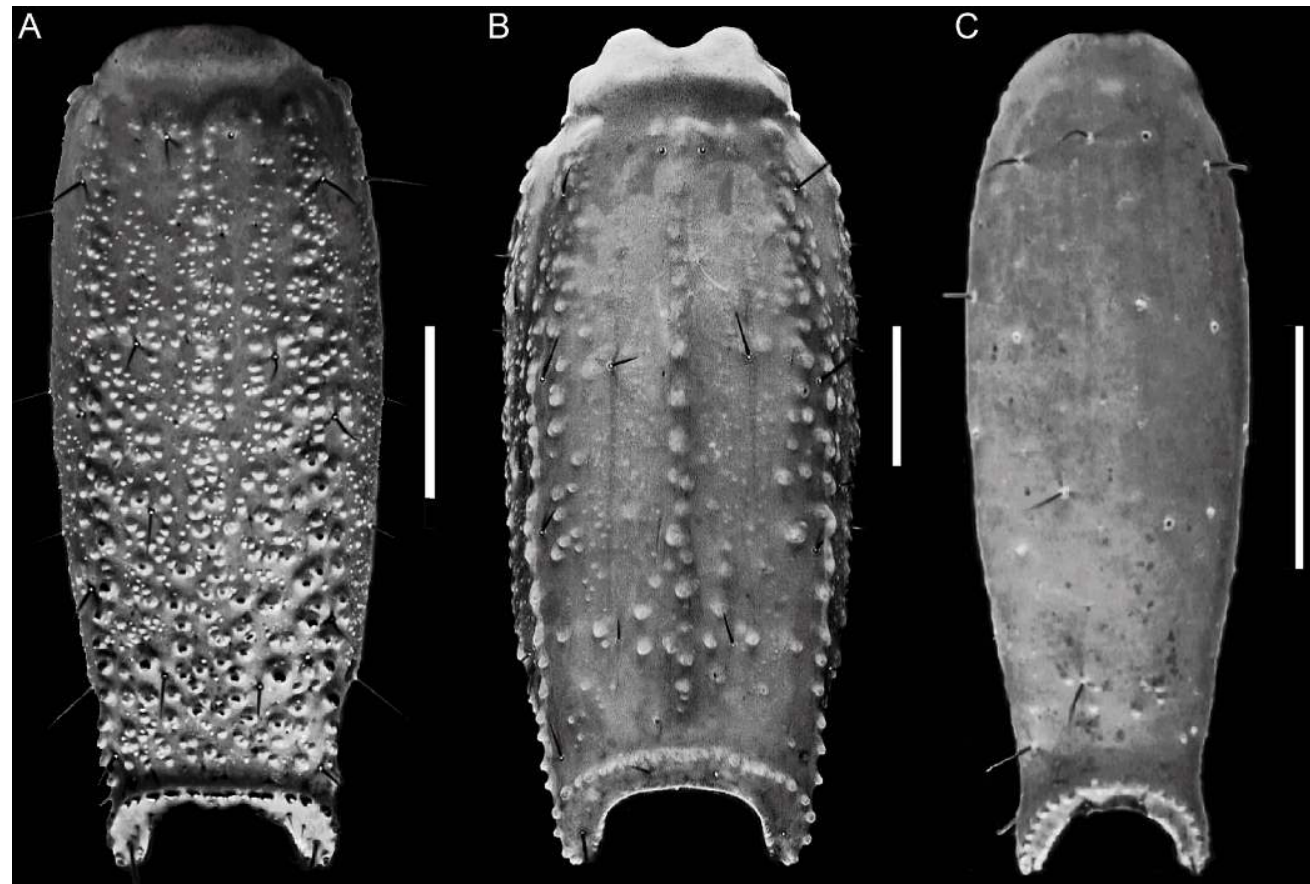

D
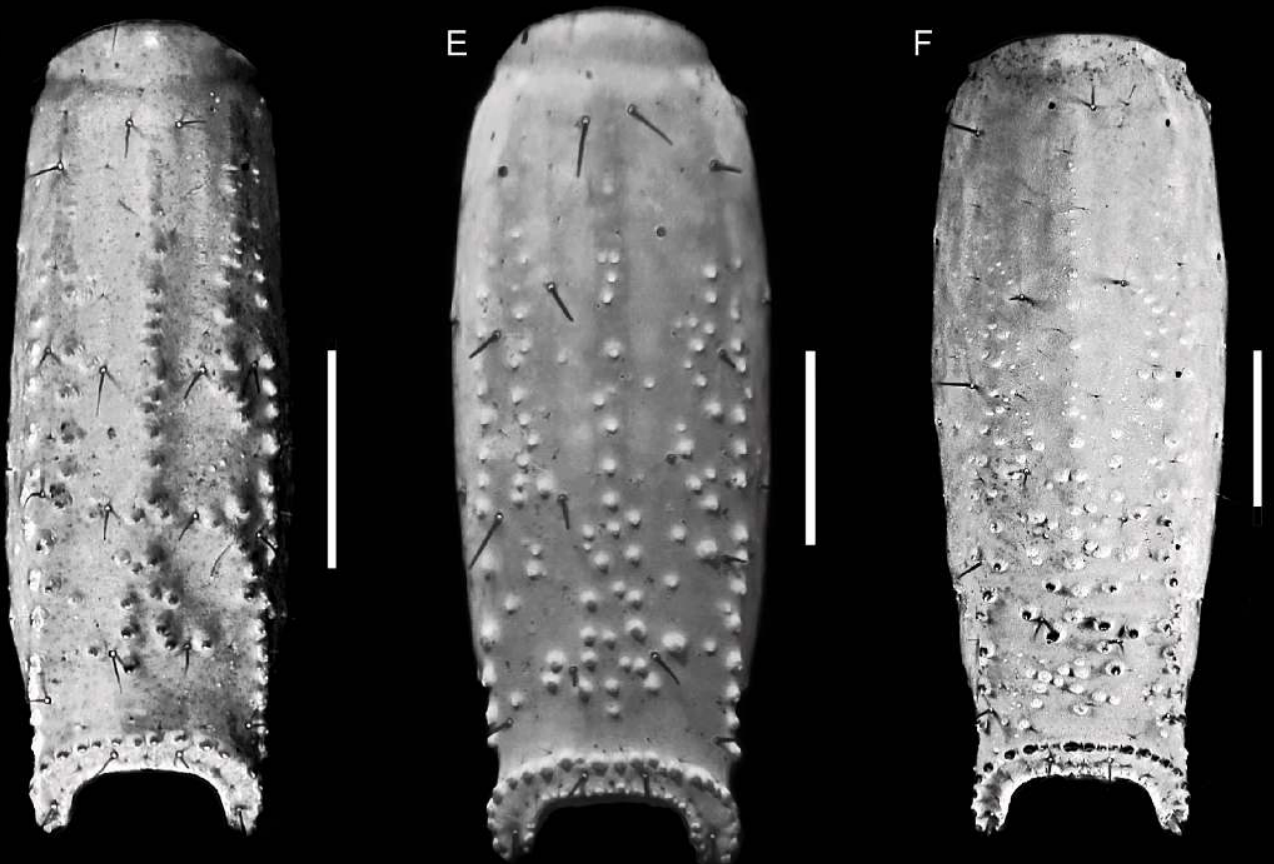

Fig. 21. Orobothriurus Maury, 1976, metasomal segment V, ventral aspect. A. Orobothriurus atiquipa Ochoa and Acosta, 2002, paratype of (MHNC). B. Orobothriurus paessleri (Kraepelin, 1911), के (MACNAr). C. Orobothriurus wawita Acosta and Ochoa, 2000, paratype of (MHNC). D. Orobothriurus calchaqui, n. sp., paratype $\delta$ (MACN-Ar). E. Orobothriurus grismadoi Ojanguren Afillastro et al., 2009, paratype $\delta$ (MACN-Ar). F. Orobothriurus huascaran, n. sp., paratype of (MACN-Ar). Scale bars $=1 \mathrm{~mm}$. 


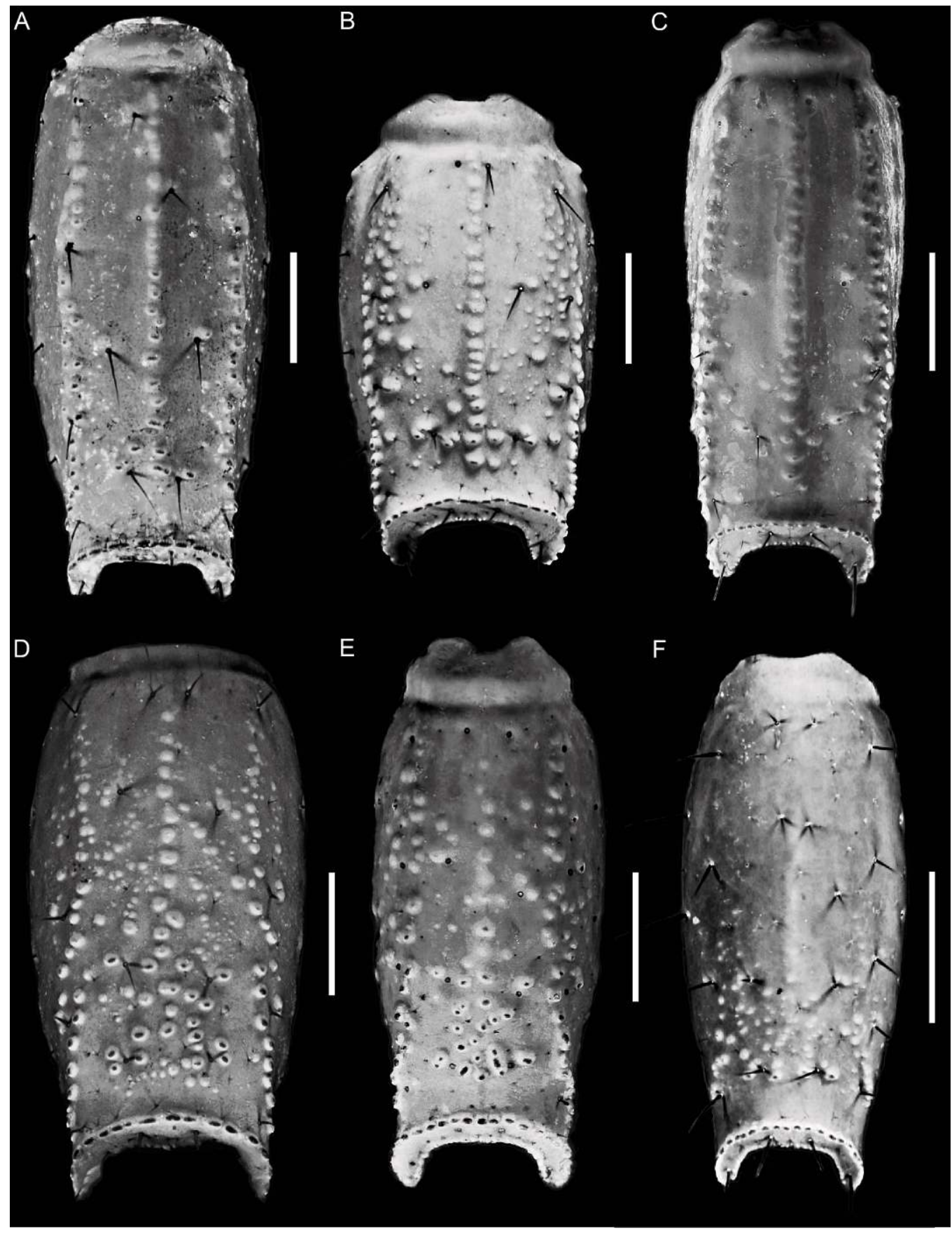

Fig. 22. Orobothriurus Maury, 1976, metasomal segment V, ventral aspect. A. Orobothriurus ampay Ochoa and Acosta, 2003, paratype $q$ (MHNC). B. Orobothriurus paessleri (Kraepelin, 1911), + (MHNC). C. Orobothriurus curvidigitus (Kraepelin, 1911), ㅇ (MHNC). D. Orobothriurus huascaran, n. sp., paratype $q$ (MACN-Ar). E. Orobothriurus parvus Maury, 1976, q (MHNC). F. Orobothriurus wawita Acosta and Ochoa, 2000, paratype + (MHNC). Scale bars $=1 \mathrm{~mm}$. 
sublaterally (fig. 29B, D). Metasomal segment I, dorsal surface unpigmented or with two small faint spots medially; lateral surfaces densely pigmented between ML and LIM carinae (fig. 29); ventral surface with two narrow VL stripes, becoming slightly broader in posterior half. Segment II, dorsal surface with two subtriangular spots medially; lateral surface as for segment I; ventral surface with one narrow VM and two narrow VL stripes, becoming slightly broader in posterior half. Segment III, dorsal surface as for segment II; lateral surfaces densely pigmented below ML carinae; ventral surface as for segment II. Segment IV, dorsal surface with reticulate pigmentation medially; lateral and ventral surfaces as for segment III. Segment V, dorsal and lateral surfaces as for segment IV; ventral surface with three dark narrow stripes (one VM and two VL), becoming slightly broader in posterior half but not contiguous with lateral pigmentation at posterior margin. Telson vesicle with narrow VM and two broad, dark VL stripes, separated by two narrow unpigmented stripes; aculeus sclerotized, dark reddish brown.

Chelicerae: Movable finger with two subdistal teeth.

Carapace: Surfaces smooth medially, finely granular near lateral margins. Anterior margin with shallow median notch (fig. 14A). Anteromedian longitudinal sulcus weakly developed; median ocular, posteromedian longitudinal and posterolateral sulci well developed. Median ocular tubercle raised, situated anteromedially; median ocelli two ocular diameters apart.

Pedipalps: Femur, DI and VI carinae complete, finely granular; DE carina complete, finely granular proximally (fig. 30A); internal surface finely and sparsely granular medially; ventral surface finely granular proximally; other surfaces smooth. Patella, DI and VI carinae complete, finely granular (fig. 30B-D); DPP carina finely granular; VPP carina vestigial, comprising two or three small granules proximally; internal surface with prominent granule adjacent to trichobothrium $i$ near DI carina. Chela manus slender, fingers relatively elongated (fig. 31); length/width ratio: $\delta$, 3.97-4.51 $(n=10$; mean $=4.17)$, ㅇ, 3.47-3.73 $(n=4$, mean $=$
3.63); length/height ratio: o , 3.40-4.03 $(n=$ 10 ; mean $=3.71)$, ㅇ, 3.07-3.31 $(n=4$, mean = 3.18); D, DS, DMA, DI, and VM carinae obsolete; intercarinal surfaces smooth; internal surface with acuminate apophysis $(\hat{\delta})$ or low bulge ( + ) near articulation of movable finger (fig. 31A, D); fingers, dentate margins each with median denticle row and 4-5 pairs of internal and external accessory denticles.

Trichobothria: Femur with 3 trichobothria, patella with 19, chela with 27 (fig. 30, 31). Patella trichobothrium $\mathrm{em}_{2}$ situated proximal to $\mathrm{em}_{1}$ in $80 \%$ of specimens (fig. 30C). Chela trichobothrium $E t_{3}$ situated proximal to Est (fig. 31C).

Tergites: Tergites I-VI, surfaces finely granular, becoming smooth posterolaterally. Tergite VII tetracarinate, paired DL carinae restricted to posterior two-thirds of segment, paired DSM carinae to posterior half; intercarinal surfaces coarsely granular, other surfaces finely granular.

Legs: Femur and patella, prolateral surfaces finely granular, retrolateral surfaces smooth. Femur, ventral carinae weakly developed; other carinae absent. Patella acarinate. Telotarsi, pro- and retroventral rows of spiniform macrosetae with following counts on leg I, 1/1; II, 2/2; III and IV, 3/3.

Pectines: Pectinal tooth count: $\delta, 18-21(n=$ 21 , mode $=18)$; + , $14(n=4$, mode $=14)$.

Sternites: Sternites III-VI, surfaces smooth; spiracles small, narrow. Sternite VII, surface smooth; VSM and VL carinae well developed ( $q$, fig. 17B) or obsolete (\$).

Metasoma: Segment I, DL carinae complete, moderately granular; ML carinae complete, moderately granular in posterior two-thirds; one pair of ML macrosetae; LIM carinae complete, moderately granular in posterior half; VL and VSM carinae complete, well developed (especially in + ), granular (fig. 17B); three pairs of VL and two pairs of VSM macrosetae. Segment II, DL carinae complete, granular; ML carinae complete, granular in posterior two-thirds; one pair of ML macrosetae; LIM carinae restricted to posterior third; VL and VSM carinae complete, well developed () or obsolete ( $\hat{\delta})$; three pairs of VL and VSM macrosetae. Segment III, DL carinae complete, granular; ML carinae complete, granular in posterior third; one pair of ML 

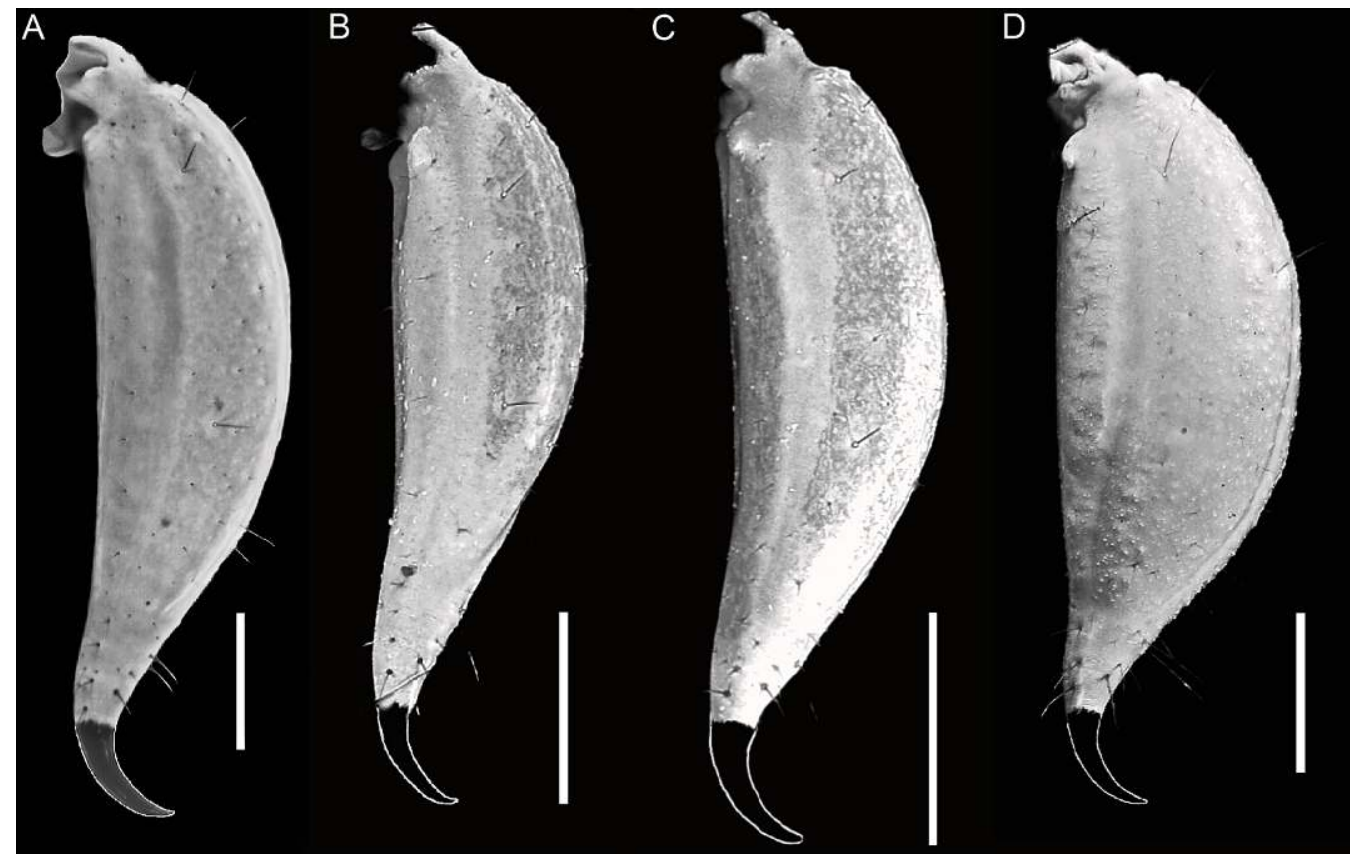

E

F
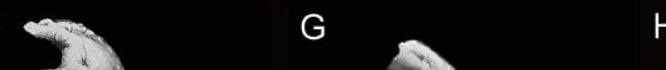

$\mathrm{H}$
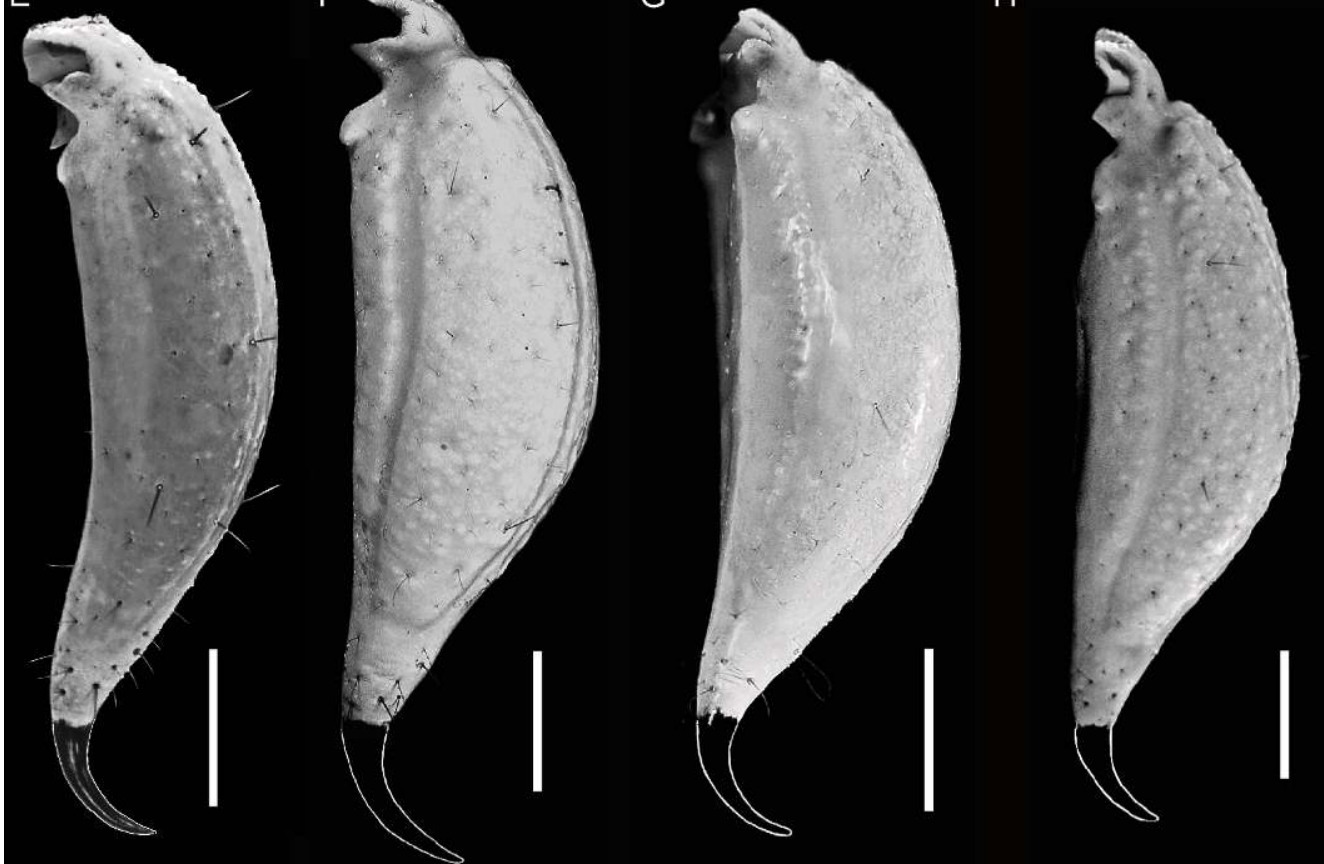

Fig. 23. Orobothriurus Maury, 1976, telson, lateral aspect. A. Orobothriurus alticola (Pocock, 1899), o (MACN-Ar). B. Orobothriurus calchaqui, n. sp., paratype of (MACN-Ar). C. Orobothriurus compagnuccii, n. sp., paratype of (MACN-Ar). D. Orobothriurus huascaran, n. sp., paratype of (MACN-Ar). E. Orobothriurus grismadoi Ojanguren Afillastro et al., 2009, paratype $\delta$ (MACN-Ar). F. Orobothriurus quewerukana, n. sp., paratype $\delta$ (MHNC). G. Orobothriurus ramirezi, n. sp., paratype $\delta$ (MACN-Ar). H. Orobothriurus tamarugal, n. sp., holotype $\delta$ (MACN-Ar). Scale bars $=1 \mathrm{~mm}$. 

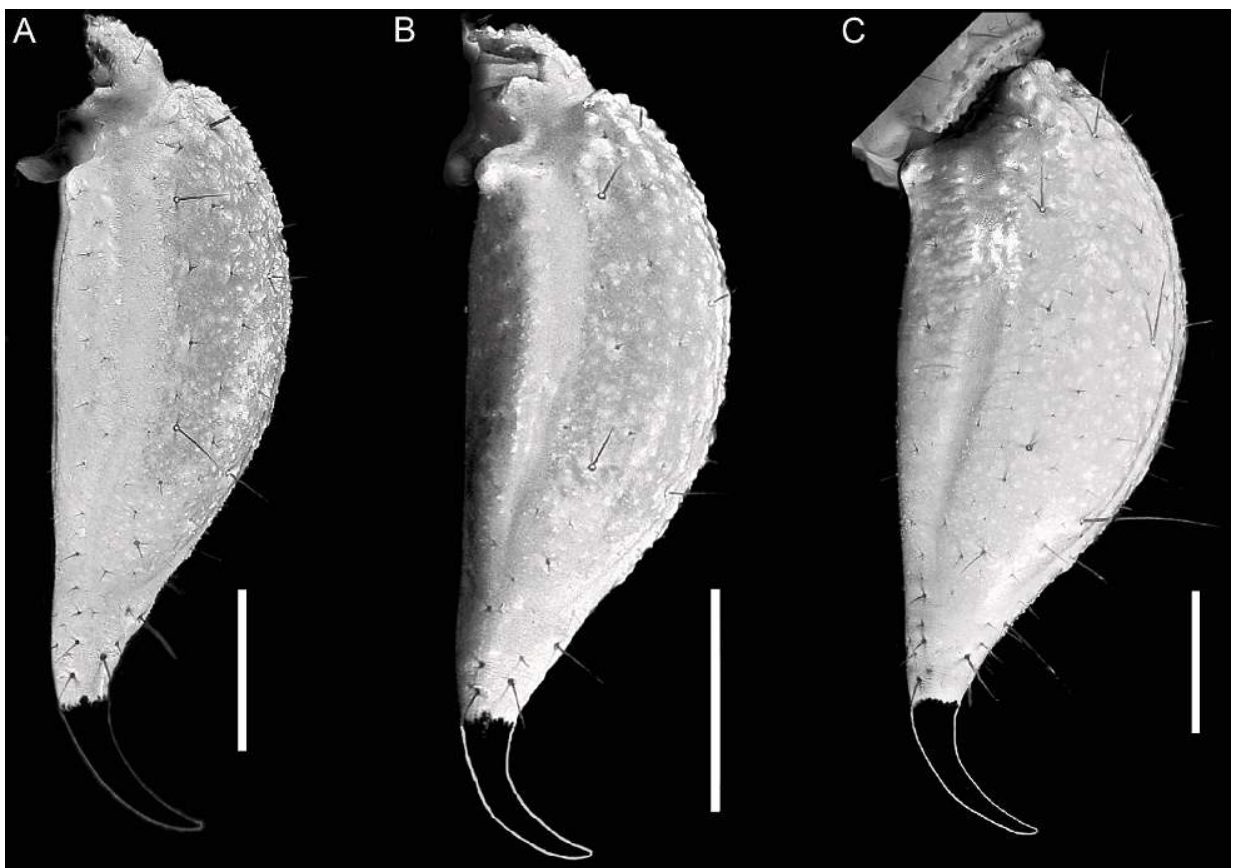

D

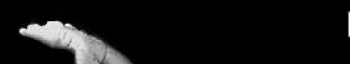

$E$
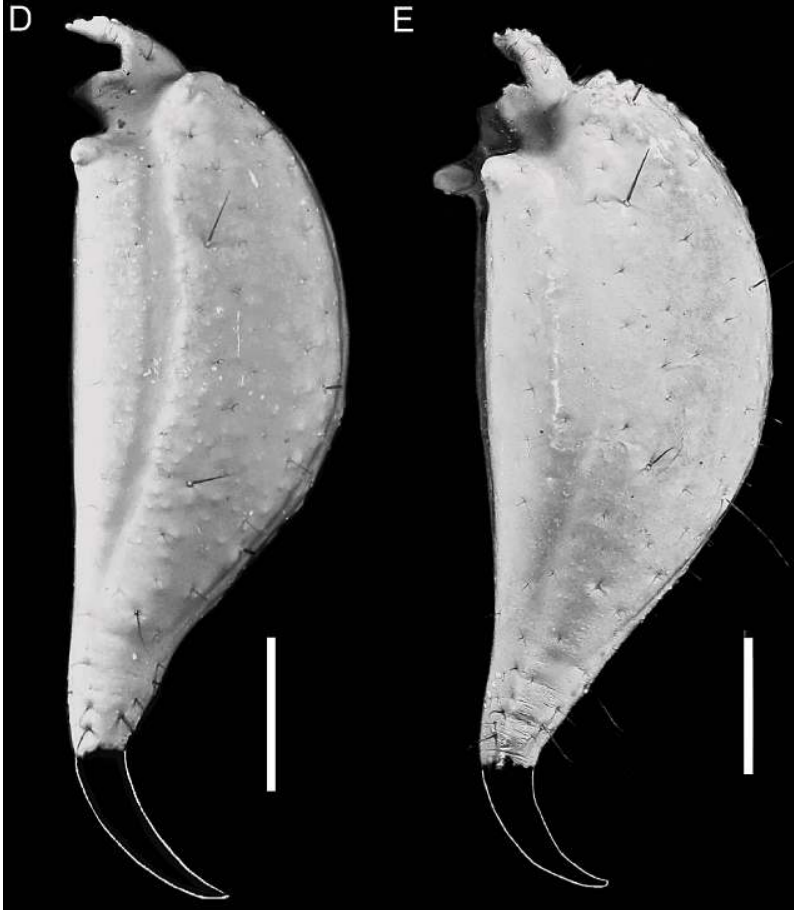

$\mathrm{F}$
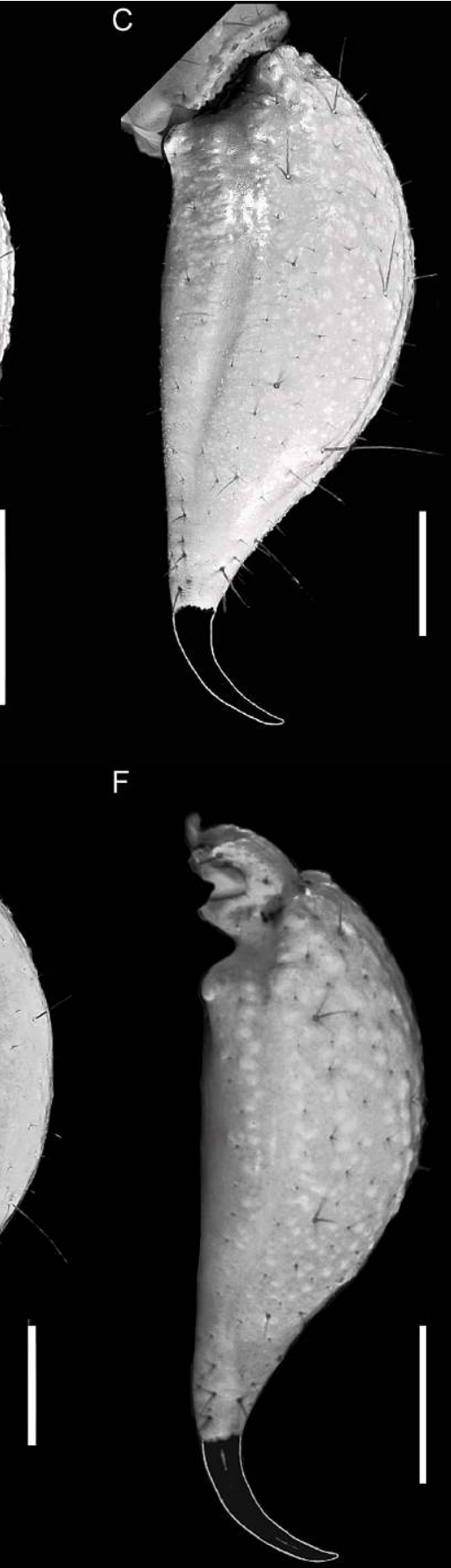

Fig. 24. Orobothriurus Maury, 1976, telson, lateral aspect. A. Orobothriurus calchaqui, n. sp., paratype \& (MACN-Ar). B. Orobothriurus compagnuccii, n. sp., paratype + (MACN-Ar). C. Orobothriurus huascaran, n. sp., paratype + (MACN-Ar). D. Orobothriurus quewerukana, n. sp., paratype + (MHNC). E. Orobothriurus ramirezi, n. sp., paratype + (MACN-Ar). F. Orobothriurus tamarugal, n. sp., paratype + (MZUC). Scale bars $=1 \mathrm{~mm}$. 


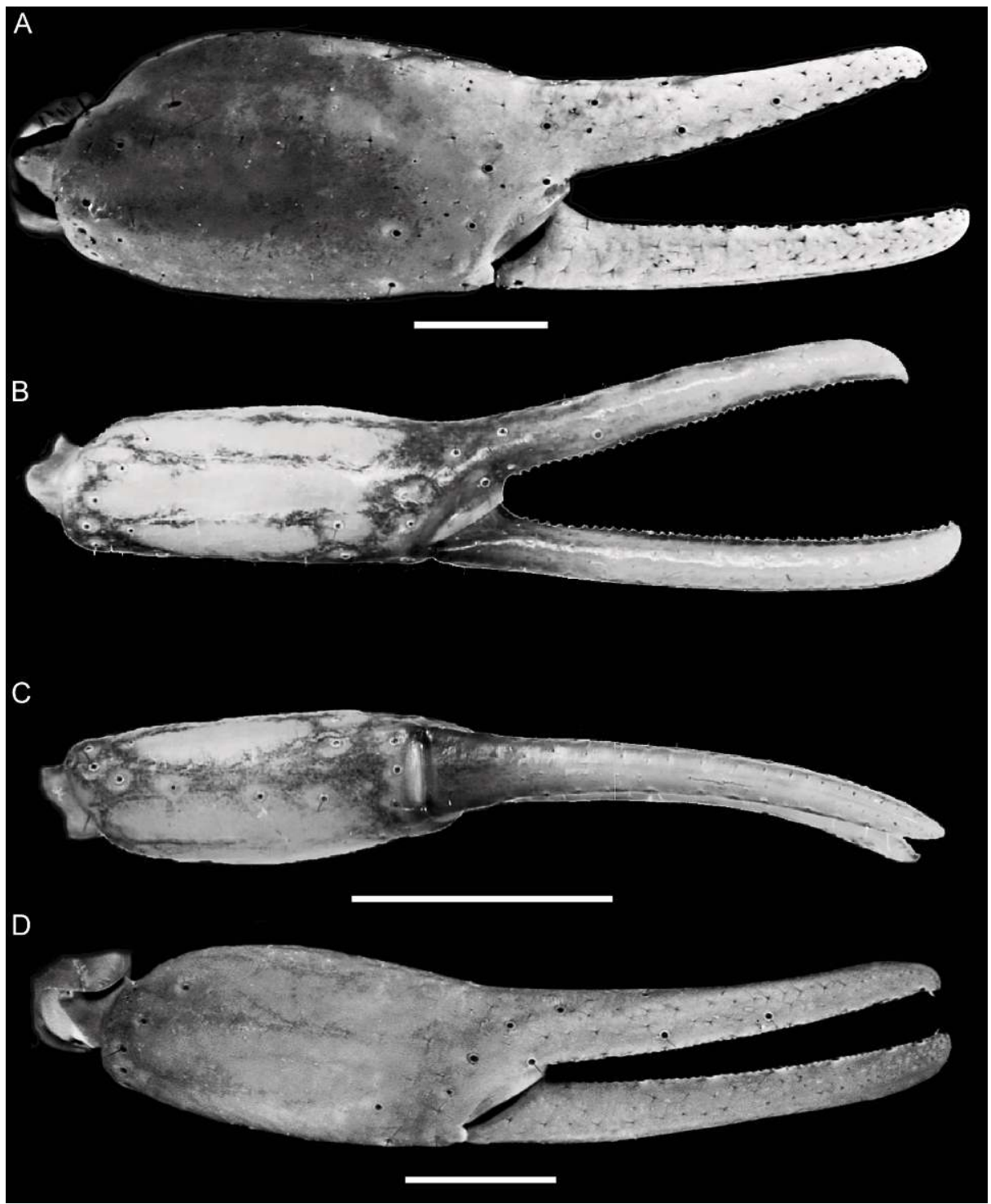

Fig. 25. Orobothriurus Maury, 1976, dextral pedipalp chela. A. Orobothriurus ampay Ochoa and Acosta, 2003, paratype + (MHNC), external aspect. B, C. Orobothriurus wawita Acosta and Ochoa, 2000, paratype $\delta$ (MHNC). B. External aspect. C. Ventral aspect. D. Orobothriurus atiquipa Ochoa and Acosta, 2002, paratype $\delta$ (MHNC), external aspect Scale bars $=1 \mathrm{~mm}$.

macrosetae; LIM carinae obsolete, restricted to posterior quarter; VL and VSM carinae complete, well developed ( + ) or absent ( $\delta$ ); three pairs of VL and VSM macrosetae. Segment IV, DL carinae complete, granular; one pair of DL macrosetae; ML carinae obsolete, restricted to posterior margin; one pair of ML macrosetae; LIM carinae absent; VL and VSM carinae absent; three pairs of VL and VSM macrosetae. Segment V, length/width ratio, of, 2.33-2.73 $(n=10$; mean $=2.52)$, 으, $1.93-1.98(n=4$; mean $=1.96)$; DL carinae granular, restricted to anterior half; ML carinae absent; four or five pairs of $\mathrm{ML}$ macrosetae; lateral margin smooth; VL carinae complete $(\delta)$ or restricted to posterior three-quarters ( $(+)$; VL and VSM carinae situated close together, fused in anterior and 


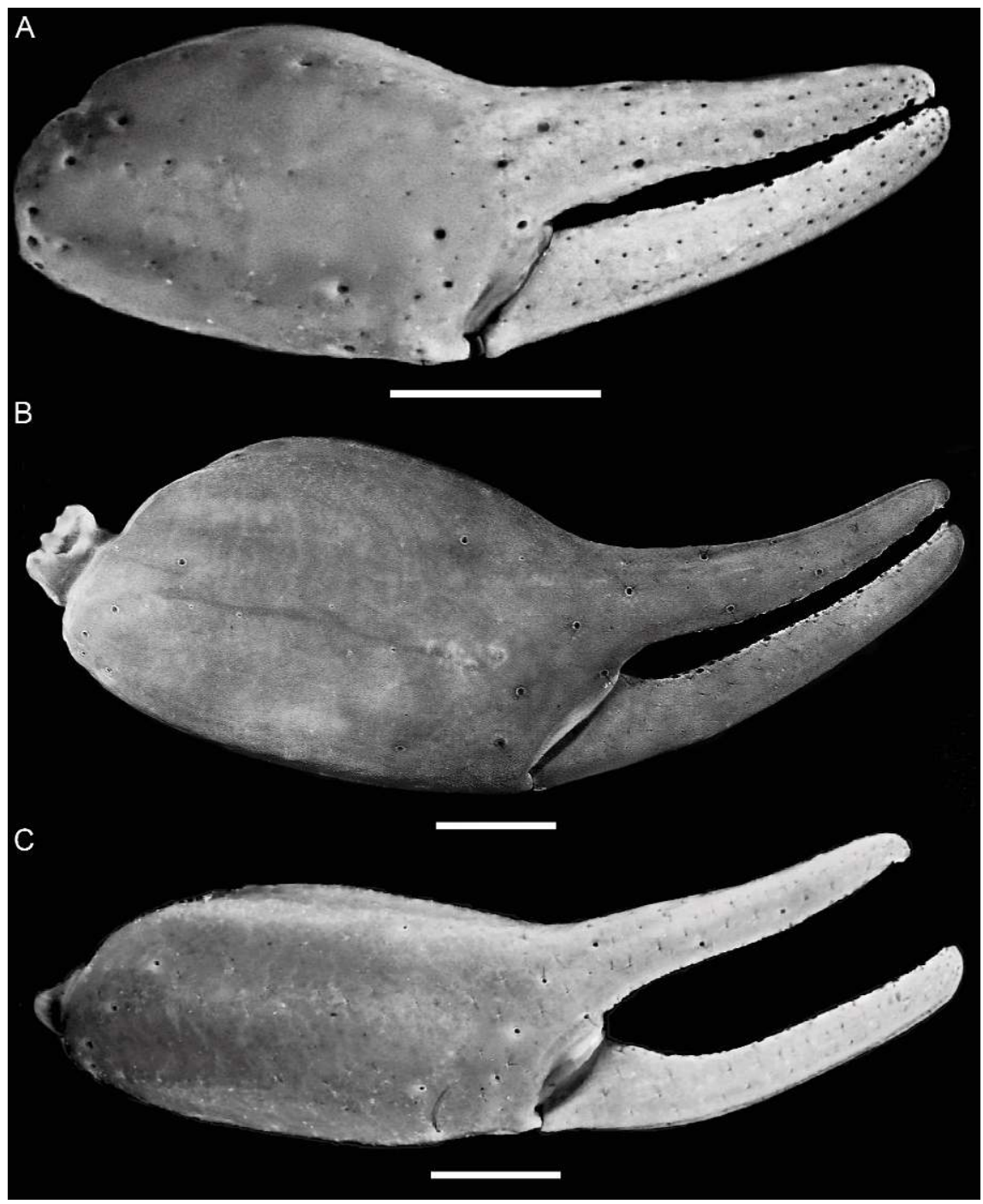

Fig. 26. Orobothriurus Maury, 1976, dextral pedipalp chela, external aspect. A. Orobothriurus parvus Maury, 1976, oै (MHNC). B. Orobothriurus paessleri (Kraepelin, 1911), oै (MACN-Ar). C. Orobothriurus curvidigitus (Kraepelin, 1911), के (MHNC), external aspect. Scale bars $=1 \mathrm{~mm}$.

posterior thirds; four pairs of VL and VSM macrosetae; two pairs of macrosetae along posterior margin; VM carina complete, obscured by surface granulation in posterior half (fig. 21D).

Telson: Length/height ratio: $\delta, 3.52-3.89$ $(n=10$, mean $=3.74)$; 우 $2.93-3.13(n=4$, mean $=3.01)$. Vesicle elongated ( $\hat{\delta}$, fig. $23 \mathrm{~B})$ or globose ( $q$, fig. 24A); dorsal surface slightly concave, gland not apparent $(\delta)$; ventral surface smooth $(\delta)$ or granular $(\phi)$. Aculeus short and curved, more so in $q$.
Hemispermatophore: Apex very well developed; distal crest curved like ventral margin. Frontal crest weakly developed, less than half length of lamina; basal part oblique; distal part short, parallel to ventral margin of lamina; lateral projections slightly undulated. Basal lobe, terminal process extending almost to distal end of frontal crest (fig. 32A, B).

REMARKS: We examined some Orobothriurus specimens from other Andean localities in Salta and Tucumán provinces of northern Argentina. However, specimens from 

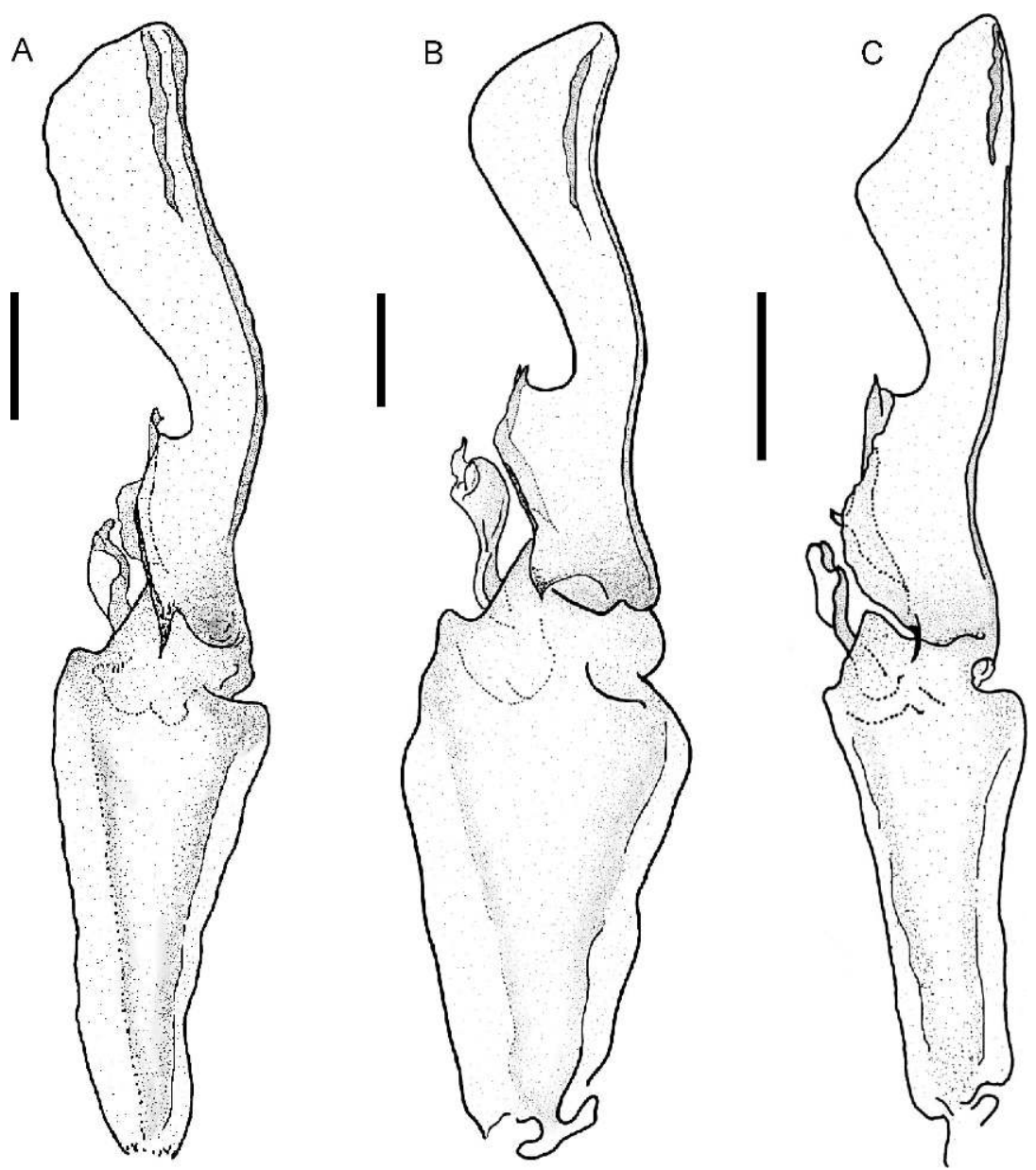

Fig. 27. Orobothriurus Maury, 1976, sinistral hemispermatophore, ectal aspect. A. Orobothriurus ampay Ochoa and Acosta, 2003, holotype ô (MUSM). B. Orobothriurus parvus Maury, 1976, ô (MHNC). C. Orobothriurus wawita Acosta and Ochoa, 2000, paratype ôे (MHNC). Scale bar $=0.5 \mathrm{~mm}$.

these localities are so scarce and the morphological differences between them and $O$. calchaqui so subtle that at this time it is unclear whether or not they are conspecific. More specimens from these Orobothriurus populations are required to establish their identity.

DisTRIBUTION: This species is known only from the type locality, Infiernillo Mountain (Tucumán Province, Argentina), belonging to the Cumbres Calchaquies, part of the Andes (fig. 54). Altitude records from Huaca Huasi $(4250 \mathrm{~m})$ and Vaca Huasi $(4300 \mathrm{~m})$ should be confirmed, because, at this latitude, the environment above $4000 \mathrm{~m}$ is usually too extreme for scorpions to survive.
ECOLOGY: All personally collected specimens were found at night in a rocky area near a small mountain river, at $2700 \mathrm{~m}$. The area is a typical Puna habitat (Cabrera and Willink, 1980). Most specimens collected were on the ground, but some were taken from near-vertical rock walls besides the river, almost $2 \mathrm{~m}$ from its base. No specimens could be found in the surrounding area, which has a sandy soil without rocks. Most of the specimens collected were adult males, moving very rapidly, probably searching for females, suggesting that late November, the start of spring in the Southern Hemisphere, is the start of the active period for this species. 

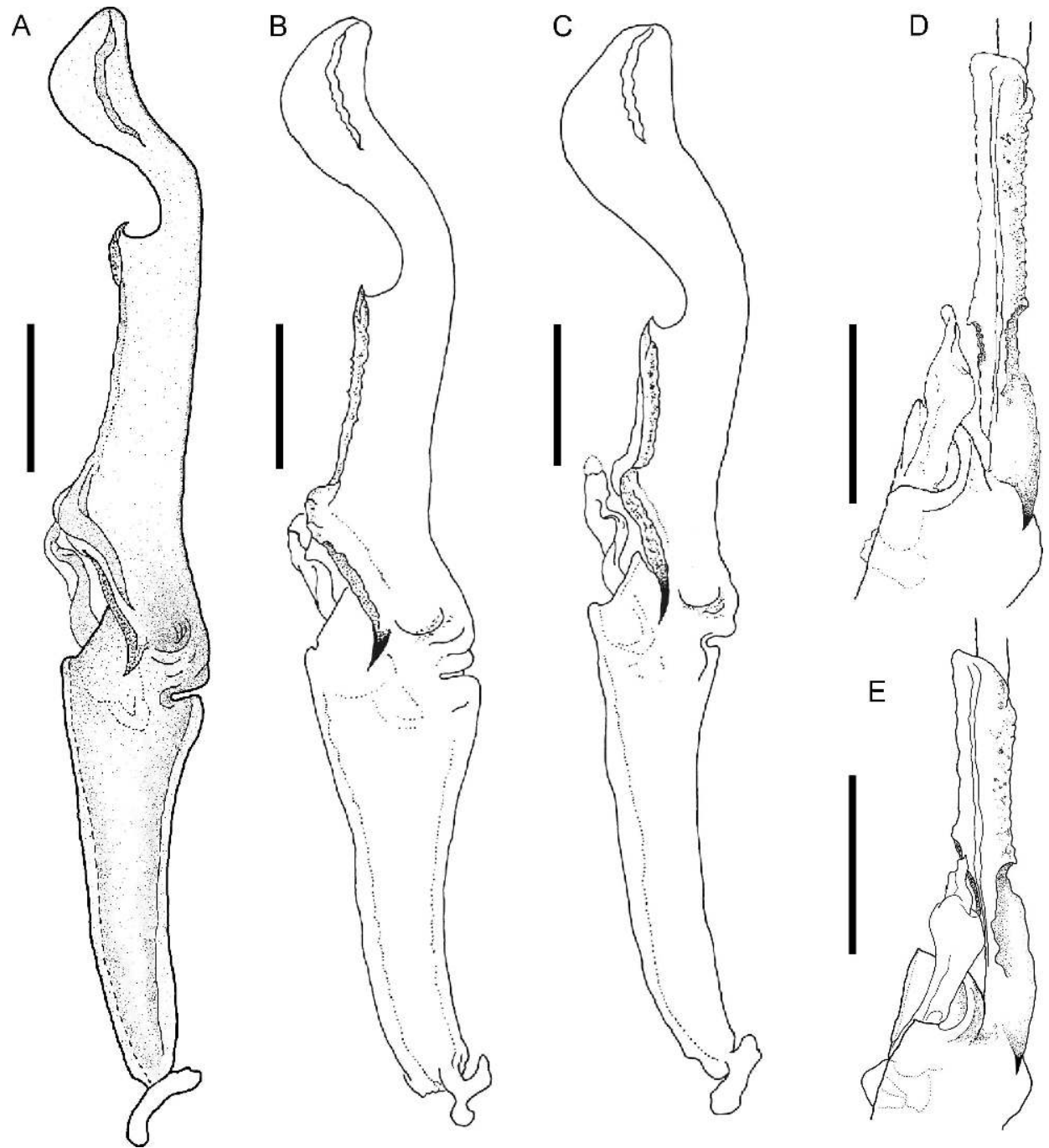

Fig. 28. Orobothriurus Maury, 1976, sinistral hemispermatophore. A. Orobothriurus atiquipa Ochoa and Acosta, 2002, holotype of (MACN-Ar), ectal aspect. B, D. Orobothriurus curvidigitus (Kraepelin, 1911), ô (MHNC). C, E. Orobothriurus paessleri (Kraepelin, 1911), oै (MHNC). B, C. Ectal aspect. D, E. Frontal crest and lobe region, dorsal aspect. Scale bar $=1 \mathrm{~mm}$.

No other scorpion species were collected in sympatry with $O$. calchaqui. However, another bothriurid, Brachistosternus intermedius Lönnberg, 1902, has been recorded in the vicinity (Ojanguren Affilastro, 2005).

Orobothriurus compagnuccii, n. sp.

Figures 14B, 18E, F, 20B, 21C, 24B, 32C, D, $33-35,36 \mathrm{~A}-\mathrm{C}, 54$; table 3

Type Material: ARGENTINA: La Rioja Province: General Lamadrid Department: Ho- lotype $\delta$ (MACN-Ar), Laguna Brava Provincial Park, road to Laguna Brava, El Peñón refuge, $28^{\circ} 32^{\prime} 18.6^{\prime \prime} \mathrm{S} 68^{\circ} 45^{\prime} 11.9^{\prime \prime} \mathrm{W}, 3200 \mathrm{~m}$, i.2003, A. Ojanguren Affilastro and P. Korob (MACN-Ar). Paratypes: Laguna Brava Provincial Park, road to Laguna Brava, $28^{\circ} 27^{\prime}$ 17.2"S 68 50'39.9"W, 3835 m, 4.iii.2002, A. Ojanguren Affilastro and P. Korob, 2 ㅇ (MACN-Ar), $28^{\circ} 30^{\prime} 26.5^{\prime \prime} \mathrm{S} \quad 68^{\prime} 47^{\prime} 57.0^{\prime \prime} \mathrm{W}$, $3600 \mathrm{~m}, 23 . i .2007$, A. Ojanguren Affilastro, L. Compagnucci, and J.J. Martínez, 2 s (MACN-Ar), $28^{\circ} 25^{\prime} 54.1^{\prime \prime} \mathrm{S} \quad 68^{\circ} 50^{\prime} 34.7^{\prime \prime} \mathrm{W}$, 


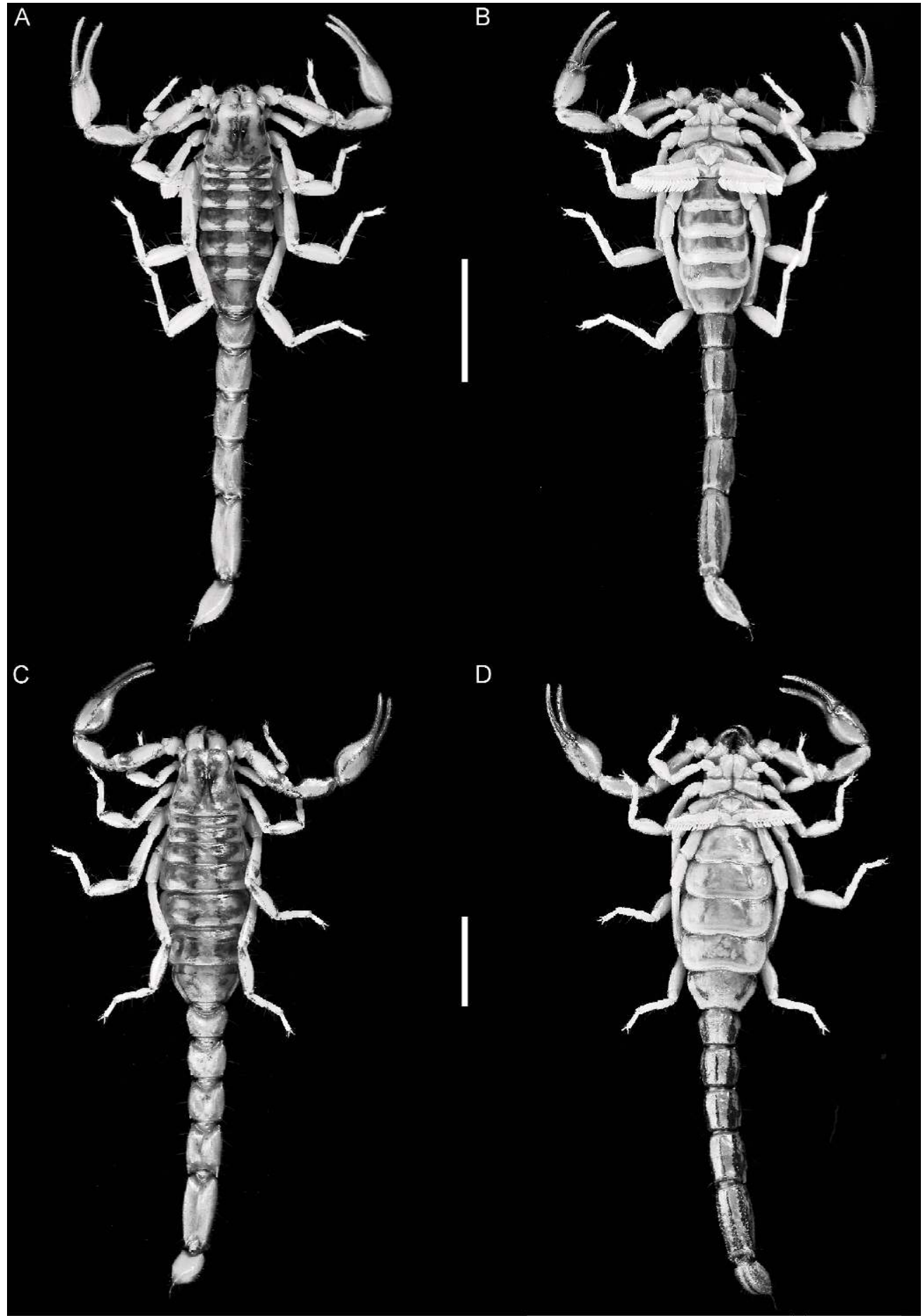

Fig. 29. Orobothriurus calchaqui, n. sp., habitus. A, B. Paratype $\delta$ (MACN-Ar). C, D. Paratype $q$ (MACN-Ar). A, C. Dorsal aspect. B, D. Ventral aspect. Scale bars $=5 \mathrm{~mm}$. 
3900 m, 27.i.2006, A. Ojanguren Affilastro, L. Compagnucci, and L. Piacentini, 2 q

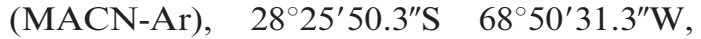
$3900 \mathrm{~m}, 27 . i .2006$, A. Ojanguren Affilastro, L. Compagnucci, and L. Piacentini, 1 juv. $\hat{\delta}$ (AMNH [LP 5847]).

ETYMOLOGY: This species is named after Argentine entomologist Luis Compagnucci (MACN), who participated in several expeditions and collected part of the type material of this species.

DiAgNOSIS: Orobothriurus compagnuccii is similar to $O$. calchaqui and $O$. famatina. The three species can be separated by the shape of the lamina of the hemispermatophore, which has a more developed apex in $O$. calchaqui and $O$. famatina: the apex comprises $52.17 \%-$ $54.54 \%(n=3$; mean $=52.98 \%)$ of the lamina in $O$. compagnuccii (fig. 36A-C), $66.6 \%-68.48 \%(n=3$, mean $=67.02 \%)$ in O. famatina (fig. $36 \mathrm{~F}-\mathrm{H}$ ), and $69.0 \%-71.56 \%$ $(n=6$; mean $=70.43 \%)$ in $O$. calchaqui (fig. $36 \mathrm{~K}-\mathrm{O}$ ). Orobothriurus compagnuccii can be separated from $O$. alticola and $O$. grismadoi by means of the same characters: the apex comprises $40.87 \% \%-46.08 \%(n=$ 20 ; mean $=43.88 \%$ ) of the lamina in $O$. alticola and 42.70-45.69\% $(n=7$; mean $=$ $44.17 \%$ ) in O. grismadoi. Orobothriurus compagnuccii can be distinguished from other Argentine species of the genus, in which the VL and VSM carinae of sternite VII and metasomal segment I are well developed (fig. 18B, D), by the weak development or absence of these carinae, which are less developed in males (fig. 18E, F).

DESCRIPTION: Based on holotype $\hat{\sigma}$ and paratypes. Measurements of holotype $\delta$ and paratype $q$ recorded in table 3 .

Total length: of, 23.91-25.6 $\mathrm{mm}(n=3$, mean $=24.86 \mathrm{~mm})$; 우, $24.5-30 \mathrm{~mm}(n=4$, mean $=27.75 \mathrm{~mm}$ ).

Color: General color yellowish with dark brown spots. Carapace, anterior margin faintly pigmented (fig. 33A, C); lateral margins with two large spots medially and posteriorly, intermediate area with reticulate pigmentation; lateral margins with two large spots laterally and posterolaterally, remaining area with reticulate pigmentation; median ocular tubercle and lateral ocelli dark brown to black; posterior half of anteromedian longitudinal sulcus, median ocular tubercle, and anterior half of postocular furrow pigmented. Chelicerae, distal margin of movable finger with reticulate pigmentation. Pedipalp femur and patella, dorsal margin densely pigmented; chela manus with seven complete longitudinal stripes along carinae, contiguous at base of movable finger; fingers and articulation of fingers pigmented. Legs, especially femur, with reticulate pigmentation near articulations and along dorsal margins. Tergites I-VI each with two dark spots sublaterally along almost entire margin and pretergites, broader near anterior margin, delimiting broad, unpigmented median stripe (fig. 33A, C); VII with four dark spots, two spots posterolaterally, occupying area between dorsolateral carinae and external margins of sclerite, and two small dark triangular spots submedially, extending along submedian carinae, delimiting unpigmented median stripe. Sternum, genital opercula, and pectines unpigmented. Sternites III-VI usually unpigmented, but lateral margins of segments $\mathrm{V}$ and VI faintly pigmented in some specimens; VII with two dark narrow stripes sublaterally (fig. 33B, D). Metasomal segment I, dorsal surface with two small, faint spots medially, separated by narrow unpigmented median stripe; lateral surfaces densely pigmented between ML and LIM carinae (fig. 33B, D); ventral surface with three narrow stripes, two VL and one VM, becoming slightly broader, but not contiguous, in posterior half. Segment II similar to segment I, but with dorsal spots joining in some specimens. Segments III and IV similar to segment I but with dorsal spots contiguous, and DL carinae faintly pigmented. Segment $\mathrm{V}$, dorsal surface with two dark stripes, contiguous in posterior third, faint or absent in some specimens; lateral surfaces each with faint narrow stripe in anterior half; ventral surface as for segments I-IV. Telson vesicle with three broad dark stripes (one VM and two VL), separated by two narrow unpigmented stripes; dorsal surface slightly pigmented on lateral margins; aculeus sclerotized, dark reddish brown.

Chelicerae: Movable finger with two subdistal teeth.

Carapace: Surfaces finely granular ( $\delta$ ) or smooth (). Anterior margin sublinear, with very shallow median notch (fig. 14B), more 
developed in $q$. Anteromedian longitudinal sulcus incomplete, absent at anterior margin and weakly developed toward median ocular tubercle; median ocular sulcus well developed; posteromedian longitudinal and posterolateral sulci obsolete (fig. 14B). Median ocular tubercle shallow, situated anteromedially; median ocelli two ocular diameters apart.

Pedipalps: Femur, DI and VI carinae complete, granular; DE carina granular, restricted to proximal three-quarters of segment (fig. 34A); internal surface finely and sparsely granular. Patella, DI and VI carinae complete, granular (\$) or obsolete (ㅇ) (fig. 34B-D); DPP comprising small granules proximally; VPP vestigial, reduced to one or two small granules medially $(\delta)$ or absent $(+$ ); internal surface with prominent granule adjacent to trichobothrium $i$ near DI carina; other intercarinal surfaces smooth. Chela manus slender, fingers relatively elongated (fig. 35); length/width ratio: $\hat{\delta}, 3.81-4.47$ $(n=3$, mean $=4.17)$, ㅇ, 3.75-4.19 $(n=4$, mean $=3.97)$; length/height ratio: 8 , 3.31-3.47 $(n=3$, mean $=3.39)$, ㅇ, 3.17-3.40 $(n=4$, mean $=3.26$ ); DMA, DI, and VM carinae obsolete; intercarinal surfaces smooth; internal surface with acuminate apophysis $(\delta)$ or low bulge ( + ) near articulation of movable finger (fig. 35A, D); fingers, dentate margins each with median denticle row and 4-5 pairs of internal and external accessory denticles.

Trichobothria: Femur with 3 trichobothria, patella with 19, chela with 27 (fig. 34, 35). Chela trichobothrium $\mathrm{Et}_{3}$ situated in same axis as, or slightly proximal to Est (fig. 35C).

Tergites: Tergites I-VI, surfaces smooth (क) or finely granular ( $\hat{\sigma})$, more coarsely so near lateral margins. Tergite VII tetracarinate, paired DL carinae restricted to posterior two-thirds of segment, paired DSM carinae to posterior third; intercarinal surfaces coarsely granular, other surfaces finely granular.

Legs: Femur and patella, prolateral surfaces finely granular $(\hat{\delta})$, retrolateral surfaces smooth. Femur, ventral carinae weakly developed; other carinae absent. Patella acarinate. Telotarsi, pro- and retroventral rows of spiniform macrosetae with following counts on leg I, 1/1; II, 2/2; III and IV, 3/3.

Pectines: Pectinal tooth count: ô, 21-23 $(n=3)$; + , $16-18(n=4$, mode $=17)$.

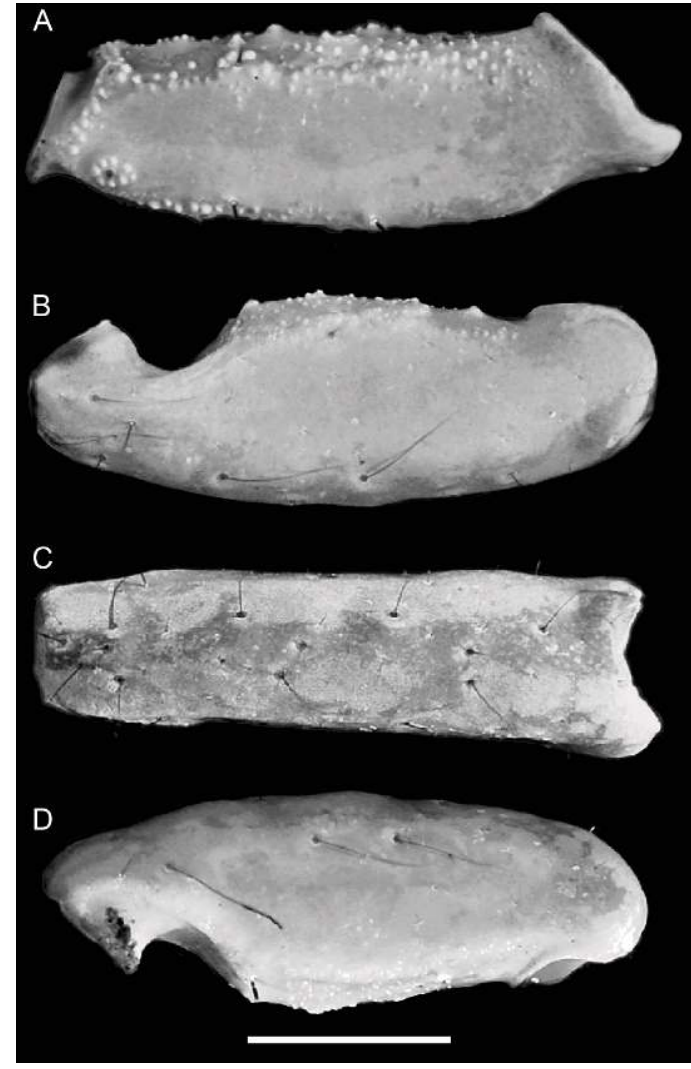

Fig. 30. Orobothriurus calchaqui, n. sp., paratype $\delta$ (MACN-Ar), dextral pedipalp femur (A) and patella (B-D). A, B. Dorsal aspect. C. External aspect. D. Ventral aspect. Scale bar $=1 \mathrm{~mm}$.

Sternites: Sternites III-VI, surfaces smooth (ㅇ) or densely granular medially ( $\delta$ ); spiracles small, narrow. Sternite VII, surface with six ventral macrosetae, smooth in anterior half, densely granular in posterior half ( $\hat{\delta})$; VL and VSM carinae obsolete (indistinct from granulation) or absent (fig. 18E, F).

Metasoma: Segment I, DL and ML carinae complete, moderately granular; one pair of ML macrosetae; LIM carinae restricted to posterior two-thirds, moderately granular; VL and VSM carinae complete but indistinct, sparsely and finely ( $\hat{\sigma})$ or coarsely ( + ) granular (fig. 18E, F); two pairs of VL and VSM macrosetae. Segment II, DL and ML carinae complete, granular; one pair of DL and ML macrosetae (DL macrosetae absent in some specimens); LIM carinae restricted to posterior quarter; VL and VSM carinae 


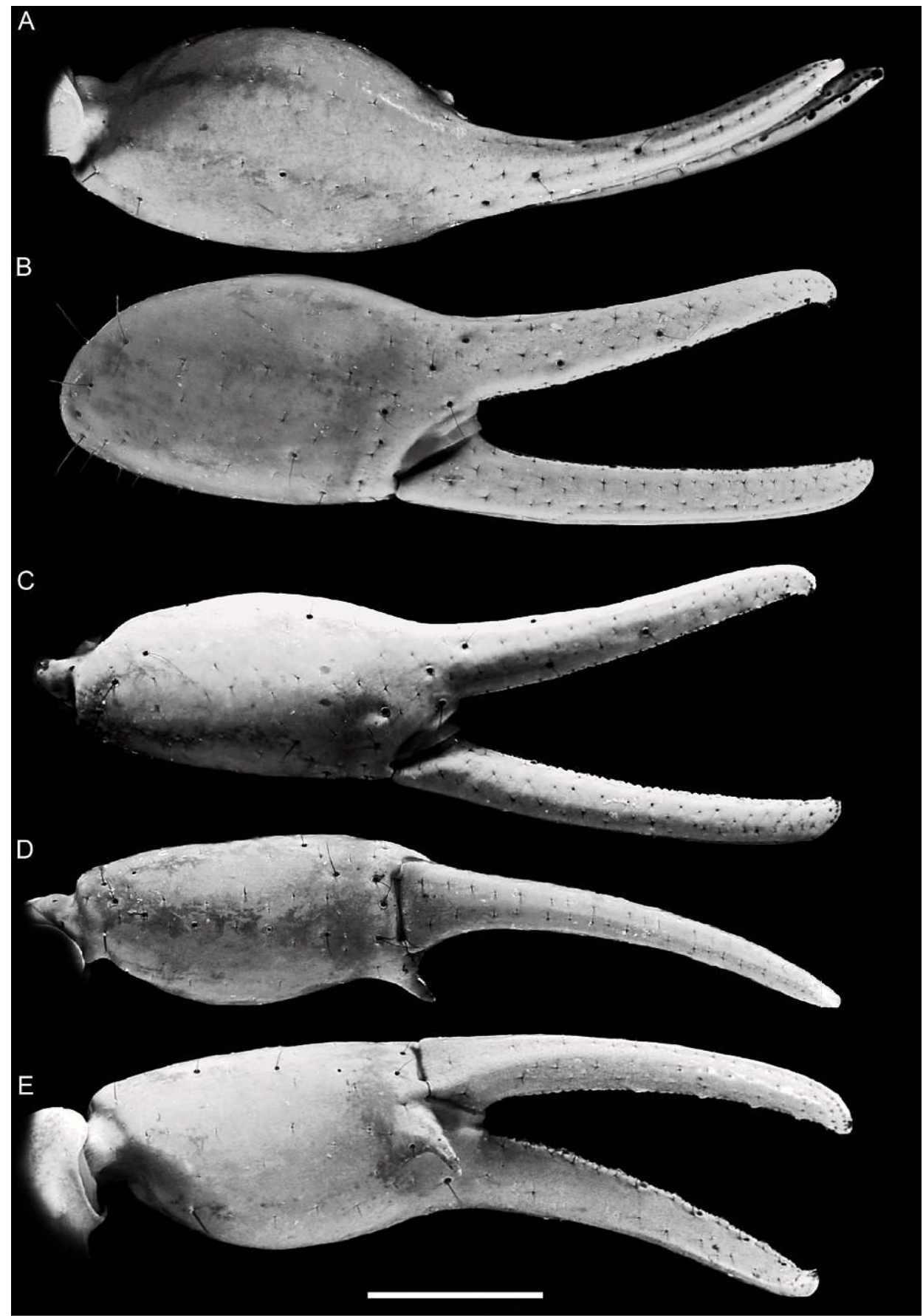

Fig. 31. Orobothriurus calchaqui, n. sp., dextral pedipalp chela. A, B. Paratype $q$ (MACN-Ar). A. Dorsal aspect. B. External aspect. C-E. Paratype ơ (MACN-Ar). C. External aspect. D. Ventral aspect. E. Ventrointernal aspect. Scale bars $=1 \mathrm{~mm}$. 

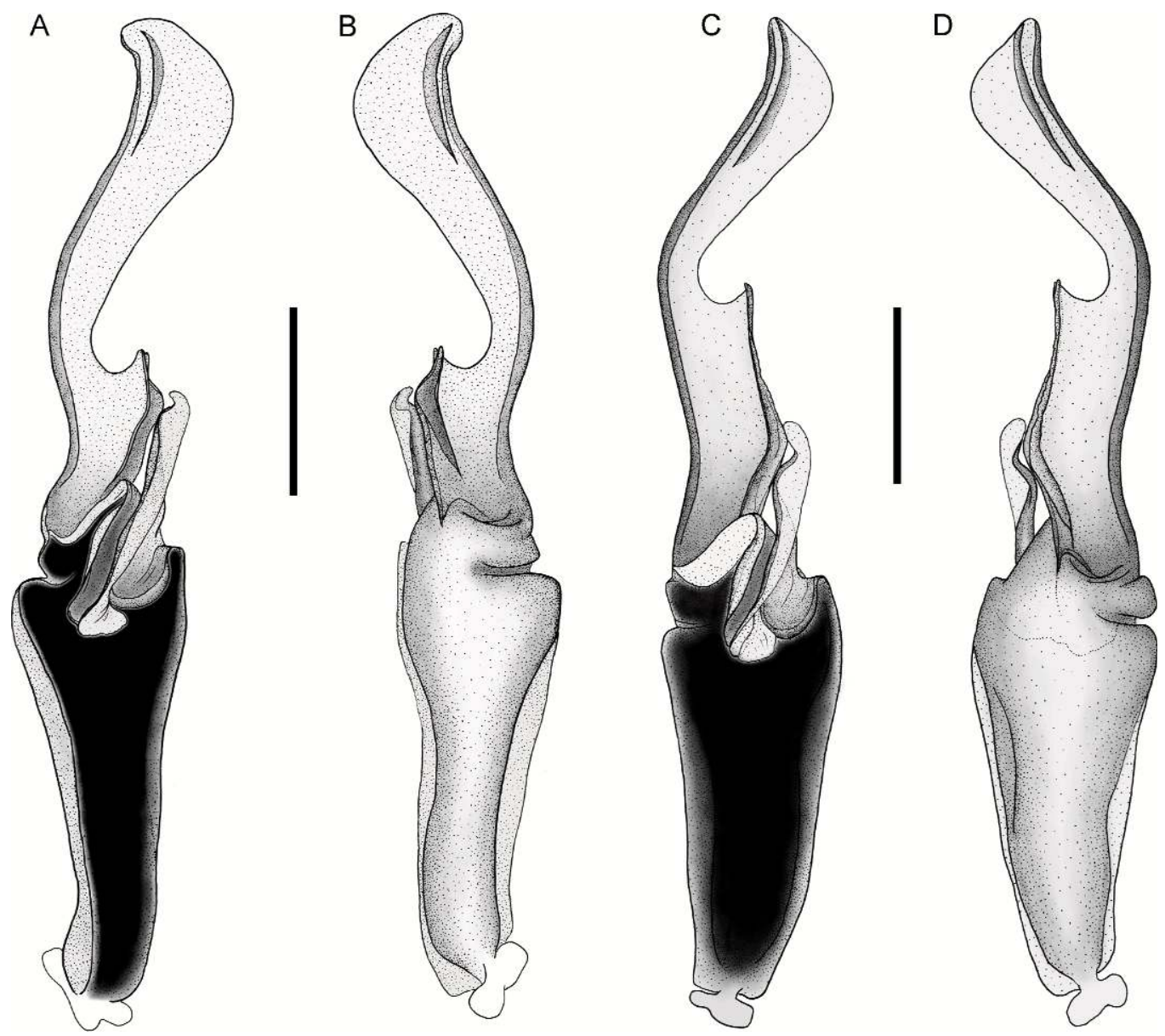

Fig. 32. Orobothriurus Maury, 1976, sinistral hemispermatophores. A, B. Orobothriurus calchaqui, n. sp., paratype ôे (MACN-Ar). C, D. Orobothriurus compagnuccii, n. sp., paratype ô (MACN-Ar). A, C. Ental aspect. B, D. Ectal aspect. Scale bar $=1 \mathrm{~mm}$.

absent ( $\hat{\delta}$, some + ) or obsolete (some + ); two pairs of VL and three pairs of VSM macrosetae (fig. 18E, F). Segment III as for segment II, but ventral intercarinal surfaces smooth and carinae less developed. Segment IV, DL carinae complete, granular; one pair of DL macrosetae; ML carinae obsolete, restricted to posterior margin; one pair of ML macrosetae; LIM carinae absent; VSM and VL carinae absent; three pairs of VSM and VL macrosetae. Segment V, length/width ratio: $\delta$, 2.92-3.17 $(n=3$, mean $=3.10)$, 우, $2.03-2.14,(n=4$, mean $=2.09)$; DL carinae granular, complete ( $(+)$ or restricted to anterior half (ठ)); DL macrosetae absent; ML carinae absent; four pairs of ML macrosetae; lateral margin smooth; VL carinae complete $(\hat{\delta})$ or restricted to posterior three-quarters ( + ); VL and VSM carinae situated close together, fused in anterior and posterior thirds; four pairs of VL and VSM macrosetae; two pairs of macrosetae along posterior margin; VM carina complete, obscured by surface granulation in posterior half (fig. 20B).

Telson: Length/height ratio: of, 3.57-4.12 $(n=3$, mean $=3.76)$; + , 2.81-2.97 $(n=4$, mean $=2.90)$. Vesicle elongated ( $\hat{\delta}$, fig. 23C) or globose ( + , fig. 24B); dorsal surface flat, gland not apparent $(\hat{\delta})$; ventral surface smooth ( $\hat{\sigma})$ or granular ( $q$ ). Aculeus short and curved, more so in + . 


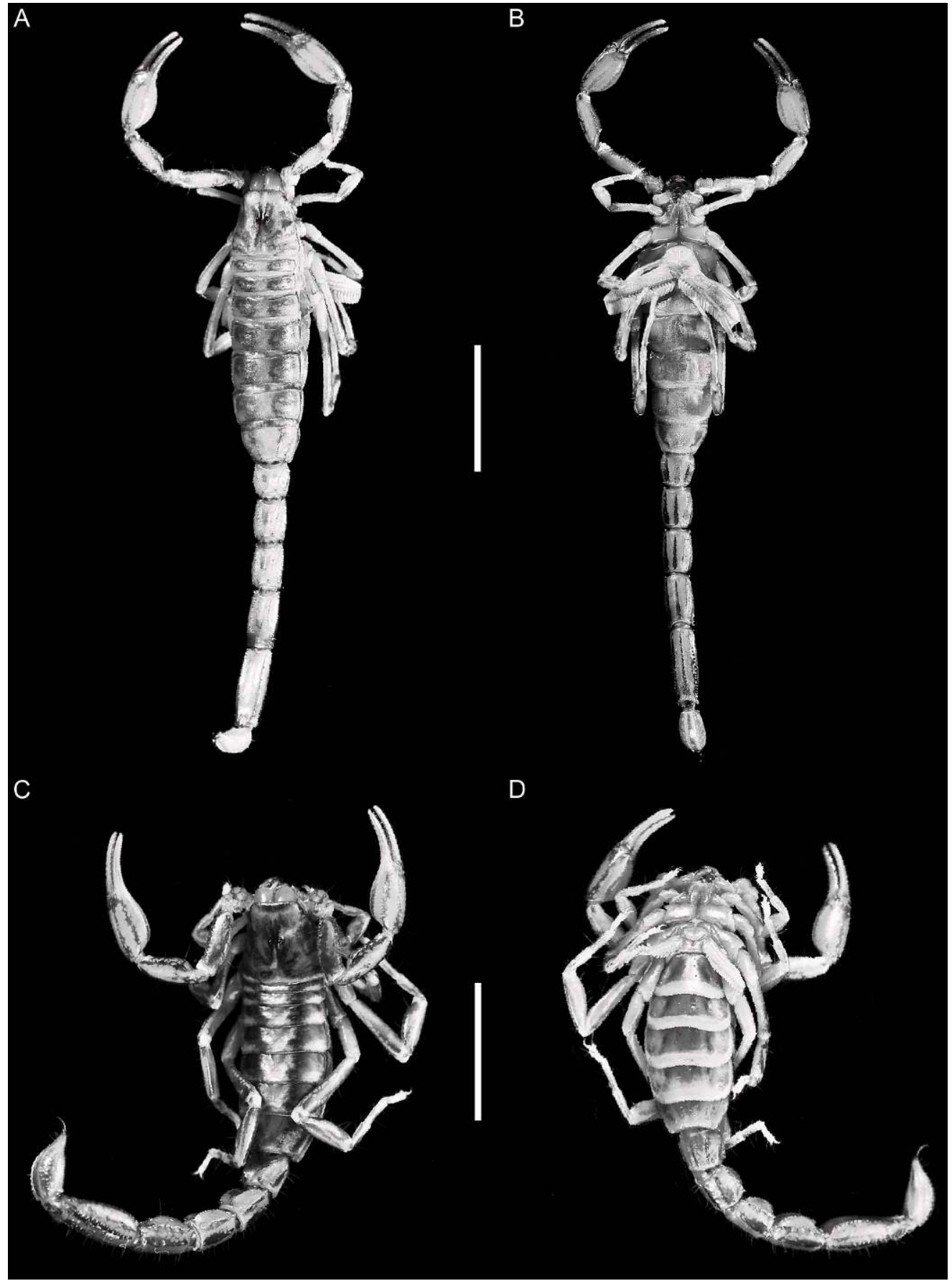

Fig. 33. Orobothriurus compagnuccii, n. sp., habitus. A, B. Paratype oै (MACN-Ar). C, D. Paratype $q$ (MACN-Ar). A, C. Dorsal aspect. B, D. Ventral aspect. Scale bars $=5 \mathrm{~mm}$. 
Hemispermatophore: Apex well developed, slightly longer than frontal crest, comprising $52.17-54.54 \%(n=3$; mean $=52.98 \%)$ of lamina; distal crest curved like ventral margin. Frontal crest divided into two parts, basal part oblique, distal part parallel to ventral margin of lamina; lateral projections slightly undulated and larger than basal part. Basal lobe, terminal process extending to median part of frontal crest (fig. 32C, D).

DisTRIBUTION: Orobothriurus compagnuccii is known only from the type locality, Laguna Brava Provincial Park, in the western Andres of La Rioja Province, northwestern Argentina (fig. 54). All specimens were collected on the ascent to Pircas Negras international pass, on the border between Argentina and Chile, at 3200-3900 m.

ECOLOGY: The habitat at the type locality is intermediate between Puna and high Andean habitats (Cabrera and Willink, 1980), with very sparse vegetation. All specimens were collected in areas with very pronounced slopes, on high rocks or spiny shrubs. We conducted several expeditions to the type locality of this species, in different years and at different times during the summer, when Orobothriurus are presumed to be most active at this latitude. However, despite considerable effort, only a few specimens were collected each time. Most were very difficult to find, hiding in inaccessible places, e.g., in vertical rocks more than two or three meters above ground level. In the same area, we collected many Brachistosternus montanus, a bothriurid species more than twice the size of $O$. compagnuccii. The scarcity of $O$. compagnuccii during summer expeditions, and its habitat preference for places inaccessible to larger scorpions adapted to sandy soils like Brachistosternus, may be explained by the abundance of $B$. montanus. It is possible that the active period of $O$. compagnuccii starts in early spring, before that of B. montanus, to avoid competition and predation by the larger species.

Orobothriurus curvidigitus (Kraepelin, 1911) Figures 11B, 12C, 13E, 14C, 19A, 22C, 26C, $28 \mathrm{~B}, \mathrm{D}, 53$

Bothriurus curvidigitus Kraepelin, 1911: 91, 97-99, fig. 7a, 7b; Mello-Leitão, 1931: 82, 92; 1932: 34; 1934: 65; 1935: 93; 1937: 103; 1945: 161; Aguilar

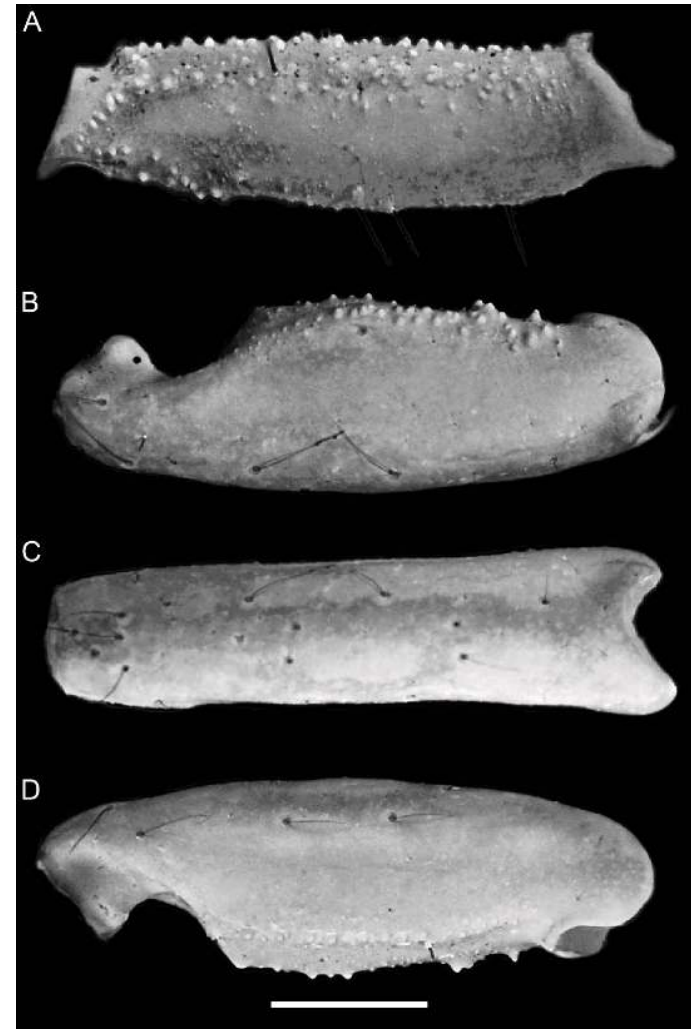

Fig. 34. Orobothriurus compagnuccii, n. sp., paratype of (MACN-Ar), dextral pedipalp femur (A) and patella (B-D). A, B. Dorsal aspect. C. External aspect. D. Ventral aspect. Scale bar = $1 \mathrm{~mm}$.

and Meneses, 1970: 2; Maury, 1973: 110; 1981: 104.

Bothriurus lampei Werner, 1916: 92 [synonymized by Maury, 1973: 110]; Lampe, 1917: 203; MelloLeitão, 1931: 88; 1932: 34; 1945: 175; Aguilar and Meneses, 1970: 2; Maury, 1973: 110; 1981: 104.

Bothriurus (Andibothriurus) curvidigitus: Bücherl et al., 1963: 216.

Bothriurus (Andibothriurus) lampei: Francke, 1974: 219.

Orobothriurus curvidigitus: Maury, 1976: 18, 19, figs. 11-24, table I; 1980: 338; 1981: 101; Francke, 1977: 75; Kovařik, 1998: 101; Acosta and Ochoa, 2000: 136, 143; Lowe and Fet, 2000: 35, 36; Acosta and Ochoa, 2001: 205; Ochoa and Acosta, 2002a: 102, fig. 9; Ochoa, 2004a: 52, 55, 73, figs. 1, 2, 13, 19, 21, table 1; 2005: 55, figs. 7,10 , table 2 .

Type Material: PERU: Arequipa Department: Arequipa Province: 1 के, 1 subad. 


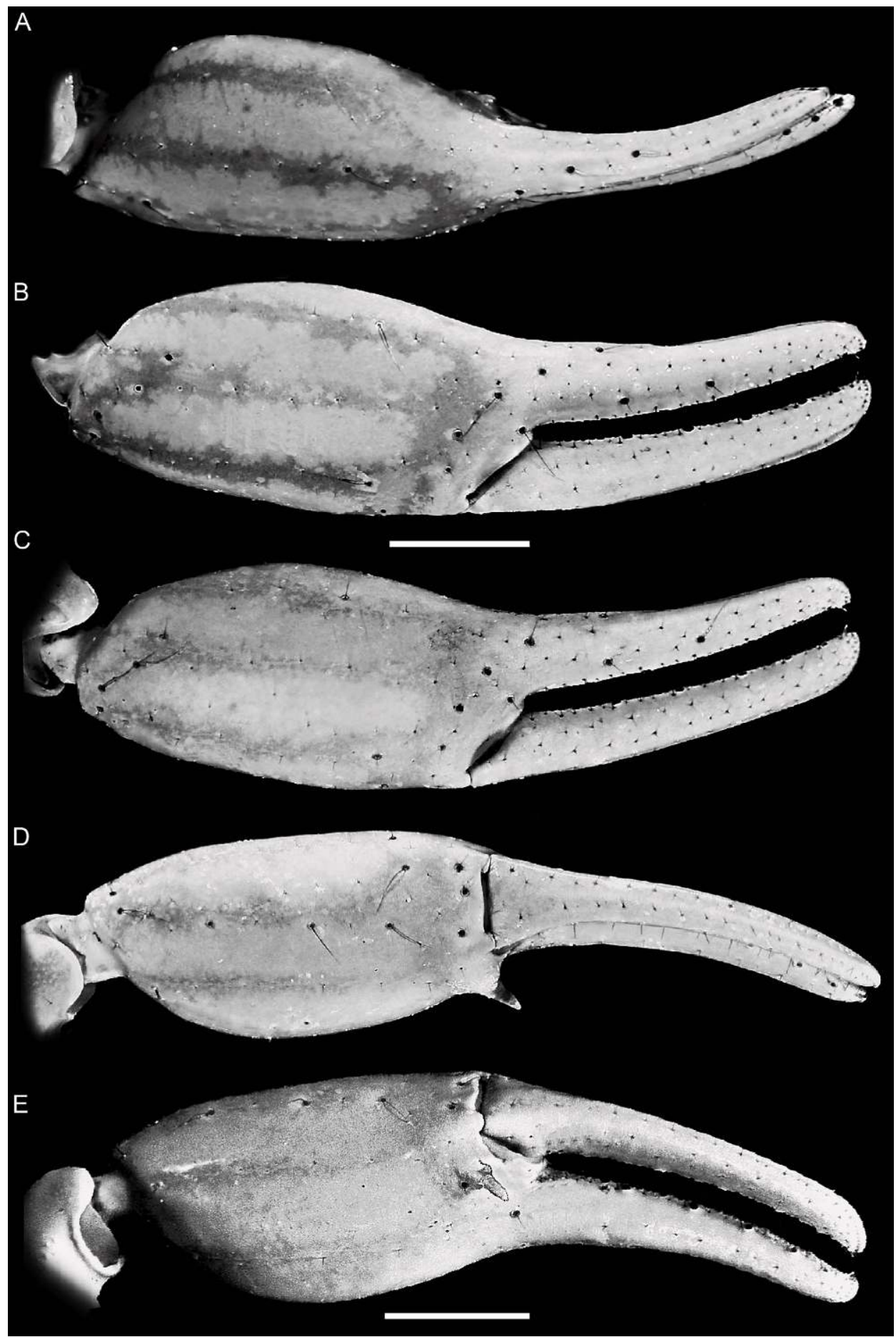

Fig. 35. Orobothriurus compagnuccii, n. sp., dextral pedipalp chela. A, B. Paratype $q$ (MACN-Ar). C-E. Paratype ơ (MACN-Ar). A. Dorsal aspect. B, C. External aspect. D. Ventral aspect. E. Ventrointernal aspect. Scale bars $=1 \mathrm{~mm}$. 
ㅇ syntypes $(\mathrm{ZMH})$, Yura $\left[16^{\circ} 12^{\prime} 53^{\prime \prime} \mathrm{S} 71^{\circ} 42^{\prime}\right.$ 33"W, $2642 \mathrm{~m}$ ], 20.vi.1909.

New Records: PERU: Arequipa Department: Arequipa Province: Agua del Milagro, Characato $\left[16^{\circ} 28^{\prime} \mathrm{S} \quad 71^{\circ} 28^{\prime} \mathrm{W}, 2460 \mathrm{~m}\right]$, 12.x.1983, E. Maury, 4 ㅇ, 8 juv. (MACN-Ar); Arequipa, 1937, P. Crawford, 1 ㅇ (MACNAr); Canchimayo, Chiguata $\left[16^{\circ} 24^{\prime} 13^{\prime \prime} \mathrm{S}\right.$ $\left.71^{\circ} 23^{\prime} 34^{\prime \prime} \mathrm{W}, 2950 \mathrm{~m}\right]$, 18.x.1998, J.A. Ochoa, 4 juv. (MHNC); Charcani, Arequipa, $2800 \mathrm{~m}$, xi.1947, W. Weyrauch, 3 o , 2 juv. (MACNAr); entrance to Charcani Quinto, near Arequipa city, Chili (Radio Azul) [16 $16^{\prime} 33^{\prime \prime} \mathrm{S}$ 71 $31^{\prime} 47^{\prime \prime} \mathrm{W}, 2550 \mathrm{~m}$ ], 28.ii.1998, E. Ponce and J.A. Ochoa, 1 juv. (MHNC); Espíritu Santo, Chiguata $\left[16^{\circ} 24^{\prime} 28^{\prime \prime} \mathrm{S} \quad 71^{\circ} 23^{\prime} 07^{\prime \prime} \mathrm{W}\right.$, 2900 m], 7.iii.1998, E. Ponce and J.A. Ochoa, 2 + 1 juv. (MHNC); Miraflores, near Chiguata [16 $\left.23^{\prime} \mathrm{S} 71^{\circ} 21^{\prime} \mathrm{W}, 3295 \mathrm{~m}\right]$, 7.iii.1998, E. Ponce and J.A. Ochoa, 12 ㅇ, 3 juv. (MHNC), 3 우 (CDA 166); near Mollebaya river [16 $28^{\prime} 56^{\prime \prime} \mathrm{S}$ $71^{\circ} 28^{\prime} 01^{\prime \prime} \mathrm{W}, 2513 \mathrm{~m}$ ], 3.iii.1998, E. Ponce, D. Muñiz and J.A. Ochoa, 2 s, 6 +, 2 juv. (MHNC), 1 sे, 1 ㅇ (CDA 167); Ribera del Rio Mollebaya [ca. $16^{\circ} 28^{\prime} 56^{\prime \prime} \mathrm{S} 71^{\circ} 28^{\prime} 01^{\prime \prime} \mathrm{W}$, $2513 \mathrm{~m}]$, 8.ii.2004, R. Cardeñas and J.A. Ochoa, 2 juv. (AMNH [LP 3064]); Socabaya [16 $\left.28^{\prime} 01^{\prime \prime} \mathrm{S} 71^{\circ} 31^{\prime} 18^{\prime \prime} \mathrm{W}, 2300 \mathrm{~m}\right], 1948$, W. Weyrauch, 1 के (MUSM), 2329 m, 5.ix.1998, U. Zanabria, 1 ㅇ (MHNC); Yura $\left[16^{\circ} 12^{\prime} 53^{\prime \prime} \mathrm{S}\right.$ $\left.71^{\circ} 42^{\prime} 33^{\prime \prime} \mathrm{W}, 2642 \mathrm{~m}\right]$, 7.viii.1939, K.P. Schmidt, 2 so, 1 juv. (FMNH), 8.viii.1939, K.P. Schmidt, 1 of, 1 क (FMNH), 10.viii.1939, K.P. Schmidt, 1 o , 1 juv. (AMNH), 9.v.1998, U. Zanabria, 1 \&, 2 juv. (MHNC); Yura, Río Yura, $20 \mathrm{~m}$ del Cementerio, $16^{\circ} 13^{\prime} 59^{\prime \prime} \mathrm{S}$ $71^{\circ} 42^{\prime} 27^{\prime \prime} \mathrm{W}, 2426 \mathrm{~m}, 29 . x i i .2007$, R. Gutiérrez, A. Quiroz and J.A. Ochoa, Serrania Esteparia, collected at night with UV light, 3 juv. (AMNH [LP 8357]). Cailloma Province: Calera Chivay

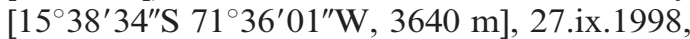
S. Rivera, 1 + (MHNC); Curiña, Yanque

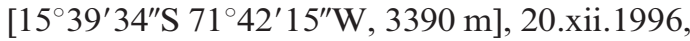
J.A. Ochoa, 10 §, 3 juv. (MHNC); Curiña [3600 m], 21.xii.1996, J.A. Ochoa, 2 + , 4 juv. (MHNC).

DiAgNOSIS: Orobothriurus curvidigitus is most closely related to $O$. paessleri, $O$. quewerukana, and O. tamarugal (fig. 5), all of which have the following characters: anterior margin of carapace with weak median projection (epistome; figs. 14C, $15 \mathrm{~A}, \mathrm{C}, \mathrm{D})$; pedipalp chela movable finger of male curved (figs. 26B, C, 43C, 51A); pedipalp femur and patella of male more elongated than that of female. Orobothriurus curvidigitus may be separated from $O$. paessleri and $O$. tamarugal by the shape of the lamina of the hemispermatophore (figs. 28B, D), the frontal crest of which is more developed and elongated in $O$. curvidigitus, but shorter in $O$. paessleri and $O$. tamarugal (fig. 28C, E, 47D). The hemispermatophore of $O$. curvidigitus differs from that of $O$. quewerukana in the slightly shorter frontal crest and absence of folds in the distal crest (figs. 28B, 40E). Orobothriurus curvidigitus also differs from $O$. quewerukana in the shape and granulation of the male telson vesicle: the length/height ratio is $3.72-4.23$ $($ mean $=3.96)$ and only the anterior third of the ventral surface is granular in $O$. curvidigitus, whereas the length/height ratio is 3.594.00 (mean $=3.76$ ) and the ventral surface is entirely granular in $O$. quewerukana (fig. 23F). The male pedipalp chela carinae are finely and sparsely granular to smooth in $O$. curvidigitus, smooth in $O$. paessleri, and finely and densely granular in $O$. quererukana and $O$. tamarugal (figs. 43D, E, 51B, C). The pigmentation pattern is the most conspicuous difference between $O$. curvidigitus and the other three species. Orobothriurus curvidigitus exhibits well-developed pigmentation on the carapace, tergites, metasoma, and pedipalps (figs. 11B, 12C, 13E), compared to $O$. quewerukana, in which the pigmentation, especially that of the carapace and tergites, is faint or barely discernible (fig. 41) and $O$. tamarugal, which is unpigmented (fig. 48). Orobothriurus curvidigitus and $O$. paessleri may be further distinguished by the dimensions of metasomal segment $\mathrm{V}$ and the setation of metasomal segment I: segment V is relatively elongated, its length greater than twice its width, in $O$. curvidigitus (fig. 22C), but shorter, its length less than twice its width, in $O$. paessleri (fig. 22B); two pairs of VSM macrosetae are present on segment I in O. curvidigitus (fig. 19A), whereas three pairs are present in O. paessleri (fig. 19B).

Distribution: Orobothriurus curvidigitus inhabits the western slopes of the Andes at 2300-3600 m (figs. 2A, 53), in the Arequipa Department, southern Peru. 

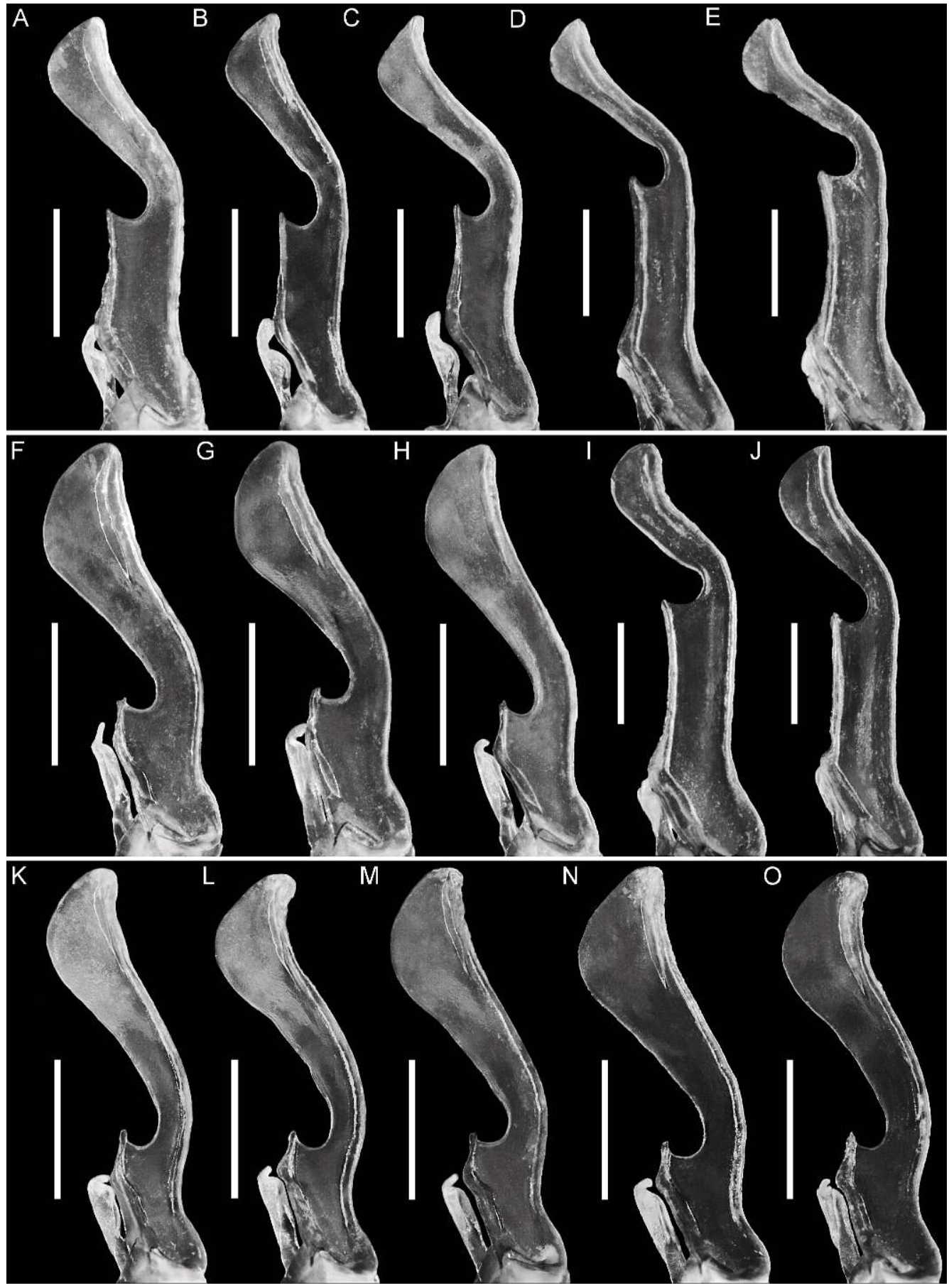

Fig. 36. Orobothriurus Maury, 1976, sinistral hemispermatophore, ectal aspect showing lamina. A-C. Orobothriurus compagnuccii, n. sp., oे holotype, के paratypes (MACN-Ar). D, E. Orobothriurus grismadoi Ojanguren Affilastro et al., 2009, ô paratypes (MACN-Ar). F-H. Orobothriurus famatina Acosta, 2001, $\hat{\delta}$ (MACN-Ar). I, J. Orobothriurus alticola (Pocock, 1899), ô (MACN-Ar). K-O. Orobothriurus calchaqui, n. sp., ô paratypes (MACN-Ar). Scale bar $=1 \mathrm{~mm}$. 
ECOLOGY: The vegetation in the areas inhabited by this species falls within the Serrania Estaparia Ecoregion, characterized by dry zones with herbaceous vegetation, cacti, shrubs, and few trees (Brack, 1986; Ochoa, 2005; fig. 2A). Three other bothriurids, Brachistosternus ehrenbergii Gervais, 1841, and two undescribed species of $\mathrm{Bra}$ chistosternus, also occur in this area.

REMARKS: We examined populations of an undetermined Orobothriurus species, apparently related to $O$. curvidigitus, from Cotahuasi and Chuquibamba in the Arequipa Department, Peru, and Lucanas in the Ayacucho Department. Lourenço and Dastych (2001: 54) listed the record from Chuquibamba under " $O$. aff. curvidigitus" and stated that it is "probably a new species." We cannot establish the identity of these specimens until more material becomes available, however.

Orobothriurus famatina Acosta, 2001 Figures $36 \mathrm{~F}-\mathrm{H}, 54$

Orobothriurus alticola: Maury 1976: 17 (part); Cei, 1982: 660, 669 [misidentification].

Orobothriurus famatina Acosta in Acosta and Ochoa, 2001: 205-211, figs. 4-14; Ochoa, 2004a: 43, 52, 55, 73, table 1; Ojanguren Affilastro, 2005: 177-181, figs. 458-466, 477, 488, 663, table 15 .

Type Material: ARGENTINA: La Rioja Province: Famatina Department: Holotype $\hat{\sigma}$ (MACN-Ar 9932), Sierra de Famatina, Rio Oro canyon, path to Mina El Oro, $29^{\circ} 06^{\prime} \mathrm{S}$ $67^{\circ} 42^{\prime} \mathrm{W}, 2450 \mathrm{~m}$, 6.xii.1998, L. Acosta, M. Acosta and G. Repossi. Paratypes: same data, 1 s, 1 क (LEA 240), 1 के (CDA 051), 1 ô (MHNC); Famatina, iv.1951, R. González Amorío, 1 \& (MACN-Ar 6844); Mina El Oro, Chilecito, ii.1956, M.E. Galiano, 1 ㅇ (MACN-Ar 6843); Sierra de Famatina, path to Mina La Mejicana, 3060 m, 5.xii.1998, L. Acosta, M. Acosta, and G. Repossi, 1 (CDA 050), 1 q (MACN-Ar 9933), 1 ㅇ (MHNC).

New Records: ARGENTINA: La Rioja Province: Famatina Department: Sierra de Famatina, Cuevas de Noronha (path to La Mejicana mine), $28^{\circ} 55^{\prime} 31^{\prime \prime} \mathrm{S} \quad 67^{\circ} 40^{\prime} 23^{\prime \prime} \mathrm{W}$, 2846 m, 29.i.2006, L. Piacentini, L. Compagnucci, and A. Ojanguren Affilastro, 2 s, 6 ㅇ, 12 juv. (MACN-Ar), 2 ㅇ (AMNH [LP 5846]).
DiAgNOSIS: Orobothriurus famatina is most closely related to $O$. calchaqui (fig. 5), from which it differs in the following respects. Orobothriurus famatina possesses one ML macroseta on metasomal segment IV and only $10 \%$ of the specimens possess one DL macroseta on segment III (absent in $90 \%$ ), whereas $O$. calchaqui possesses two or three macrosetae on segment IV and $70 \%$ of the specimens possess one DL macroseta on segment III (absent in 30\%). There are also differences in the trichobothrial pattern. Pedipalpal chela trichobothria $d b$ and $E t_{3}$ are located in the same axis as, or slightly distal to Est in $70 \%$ and $30 \%$ of the specimens of $O$. famatina, respectively, but always located proximal to Est in $O$. calchaqui. Pedipalp patella trichobothrium $e m_{2}$ is located in the same axis as, or distal to $e m_{1}$ in $70 \%$ of the specimens of $O$. famatina, but proximal to $e m_{1}$ in $80 \%$ of the specimens of O. calchaqui. Orobothriurus famatina may be differentiated from $O$. compagnucci by the more elongated apex of the hemispermatophore lamina: the apex comprises 66.6$68.48 \%(n=3$, mean $=67.02 \%)$ of the lamina in $O$. famatina (fig. $36 \mathrm{~F}-\mathrm{H}$ ) and $52.17 \%-54.54 \%(n=3$; mean $=52.98 \%)$ in O. compagnuccii (fig. 36A-C). The two species can also be separated by the VL and VSM carinae of metasomal segment I and sternite VII in the male, which are well developed in $O$. famatina, and weakly developed to absent in O. compagnuccii (fig. 18F).

DISTRIBUTION: Orobothriurus famatina is known only from high altitudes (2500$3200 \mathrm{~m}$ ) of the Sierra Famatina, a mountain range close to the Andes, in La Rioja Province of central-western Argentina (figs. 3G, 54).

ECOLOGY: This species inhabits an area of grassland and shrub steppe that belongs to the Prepuna and Altoandina phytogeographic provinces (Cabrera and Willink, 1980; fig. 3G). It occurs in sympatry with another bothriurid, Bothriurus olaen Acosta, 1997 (Ojanguren Affilastro, 2005).

\section{Orobothriurus grismadoi}

Ojanguren Affilastro et al., 2009

Figures 4B, 13G, 21E, 23E, 36D, E, 54

Orobothriurus grismadoi Ojanguren Affilastro et al., 2009: 29-35, figs. 1, 3-13, 15-17, 20-24, 35 , tables 1,2 . 


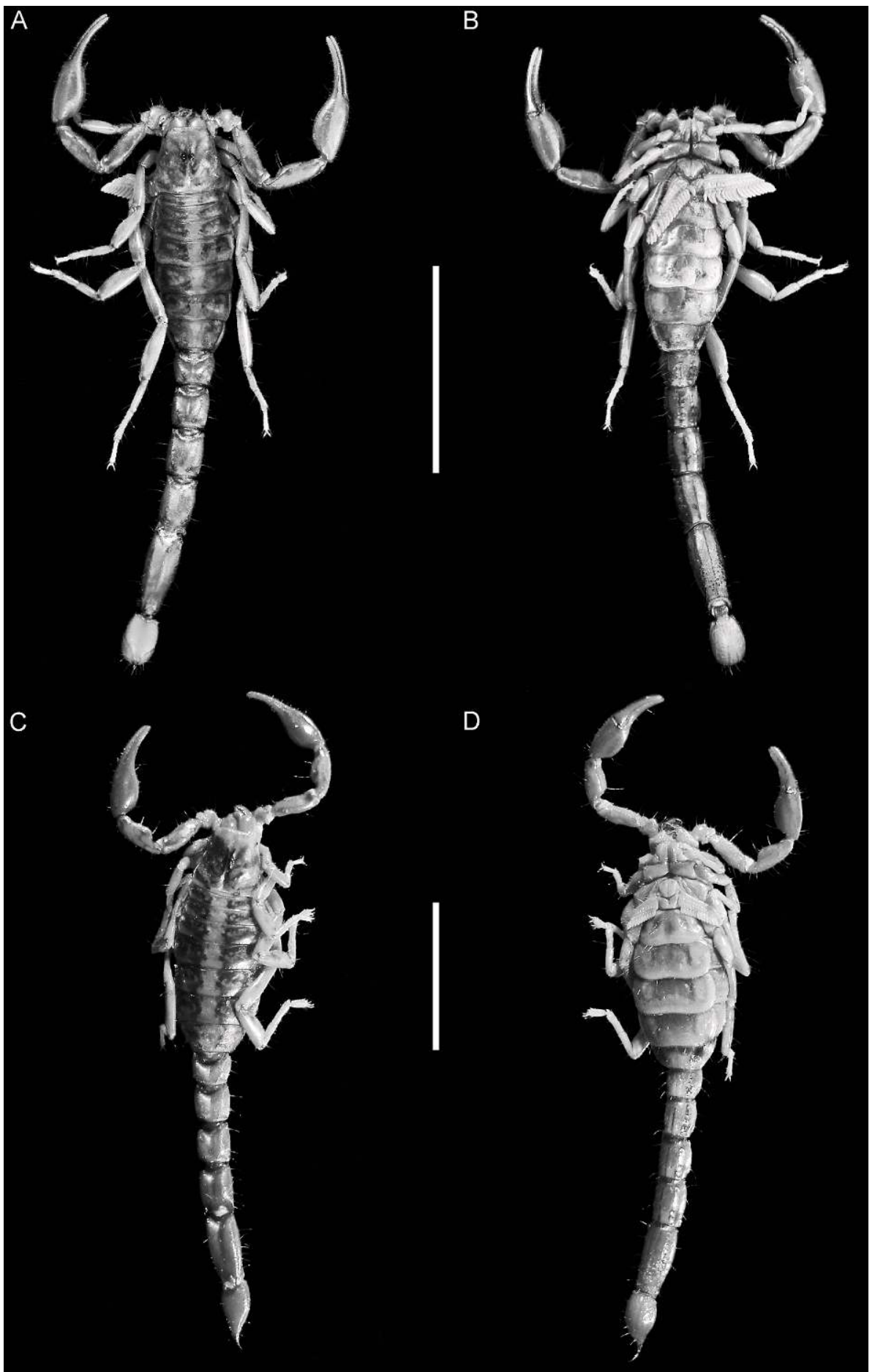

Fig. 37. Orobothriurus huascaran, n. sp., habitus. A, B. Paratype $\delta$ (MACN-Ar). C, D. Paratype $q$ (MACN-Ar). A, C. Dorsal aspect. B, D. Ventral aspect. Scale bars $=10 \mathrm{~mm}$. 
Type Material: ARGENTINA: Mendoza Province: Malargüe Department: Holotype of (MACN-Ar 17986), Cerro Nevado, $35^{\circ} 35^{\prime} 45.06^{\prime \prime} \mathrm{S} \quad 68^{\circ} 30^{\prime} 24.12^{\prime \prime} \mathrm{W}, 3130 \mathrm{~m}$, 25.ii.2006, F. Fernández Campón and S. Lagos Silnik. Paratypes: same data, 6 s, 2 ㅇ (MACN-Ar 17987), 2 o (CDA), 1 juv. (IADIZA); Cerro Nevado, $35^{\circ} 36^{\prime} 04.08^{\prime \prime} \mathrm{S}$ $68^{\circ} 30^{\prime} 44.28^{\prime \prime} \mathrm{W}, 2900 \mathrm{~m}, 16 . x i .2004, \mathrm{G}$. Flores, 1 (CDA), 2949 m, 7.i.2006, F. Fernández Campón and S. Lagos Silnik, 1 juv. (IADIZA); Cerro Nevado, 35 36'02.46"S $68^{\circ} 30^{\prime} 40.92^{\prime \prime} \mathrm{W}, 2953$ m, ii.2006, F. Fernández Campón and S. Lagos Silnik, 1 s (AMNH), same data except 25.ii.2006, $5 \hat{\delta}$ (IADIZA), 1 के (AMNH).

New Records: ARGENTINA: Mendoza Province: Malargüe Department: Cerro Nevado, road to antennas, SW face of mountain, $35^{\circ} 35^{\prime} 58.6^{\prime \prime} \mathrm{S} 68^{\circ} 30^{\prime} 43.9^{\prime \prime} \mathrm{W}, 2984 \mathrm{~m}$, 23.iv.2011, C.I. Mattoni and M. Vivanco, UV sampling on rocky slopes, with small bushes and shrubs, no moon, $3^{\circ} \mathrm{C}$, winds up to $45 \mathrm{~km} / \mathrm{h}$, wind chill factor $-10^{\circ} \mathrm{C}$, specimens walking or sitting on rocks, 5 s, 6 ? , 4 juv. (LBRE), 4 juv. (AMNH), 1 juv. (AMNH [LP 10968]).

DiAgnosis: Orobothriurus grismadoi is similar to $O$. alticola in pigmentation pattern, external morphology, and hemispermatophore. The two species may be separated by the shape of the hemispermatophore: in $O$. grismadoi, the apex is more slender and the angle it forms with the rest of the distal lamina more acute (fig. $36 \mathrm{D}, \mathrm{E}$ ) than in $O$. alticola (fig. 36I, J). Additionally, the apex comprises $42.70 \%-45.69 \%(n=7$; mean $=44.17 \%)$ of the lamina in $O$. grismadoi and $40.87-46.08 \%$ $(n=20 ;$ mean $=43.88 \%)$ in $O$. alticola . Males of $O$. grismadoi may also be recognized by the slender telson vesicle, with a concave dorsal surface; the vesicle is broader, with a flat dorsal surface, in males of $O$. alticola (fig. 23A, E). Orobothriurus grismadoi is also more densely pigmented, with tergite VII entirely pigmented (fig. 13G), compared to $O$. alticola, in which tergite VII exhibits paired lateral spots of pigmentation delimiting an unpigmented median stripe (fig. 13F).

DISTRIBUTION: Orobothriurus grismadoi is the southernmost species of the genus. It is known only from the Cerro El Nevado, an

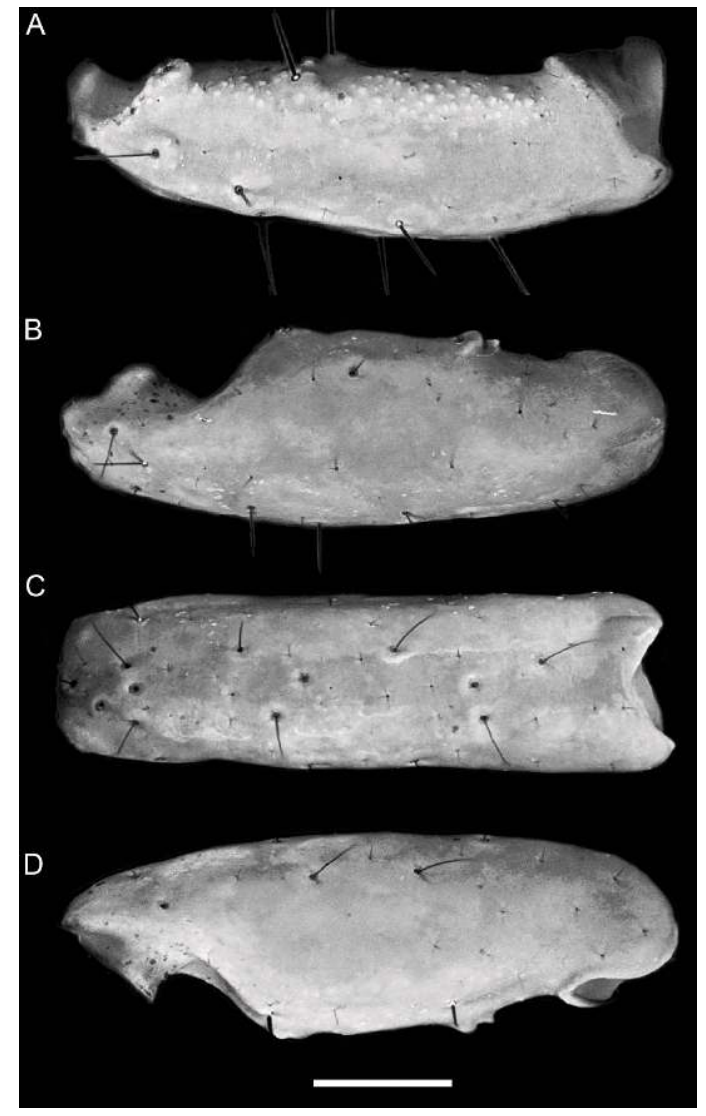

Fig. 38. Orobothriurus huascaran, n. sp., paratype ô (MHNC), dextral pedipalp femur (A) and patella (B-D). A, B. Dorsal aspect. C. External aspect. D. Ventral aspect. Scale bar $=1 \mathrm{~mm}$.

isolated mountain range, $200 \mathrm{~km}$ east of the Andes, in central-western Mendoza Province, Argentina (fig. 54). The El Nevado range, with a maximum altitude of $3833 \mathrm{~m}$, extends north to south between $34^{\circ} \mathrm{S}$ and $36^{\circ} \mathrm{S}$, parallel to the Andes, and is separated from it by a plateau of $1800 \mathrm{~m}$ (Ojanguren Affilastro et al., 2009). El Nevado is an extinct, eroded, stratovolcano, unrelated to and younger than the Andes. The age of these volcanoes is estimated at between 2.5 and 0.01 MA (Caminos, 1999).

ECOLOGY: Orobothriurus grismadoi was collected in a high-altitude shrub steppe at 2900-3130 m (fig. 3D), in an area belonging to the Altoandina and Puna phytogeographic provinces (Cabrera and Willink, 1980). 


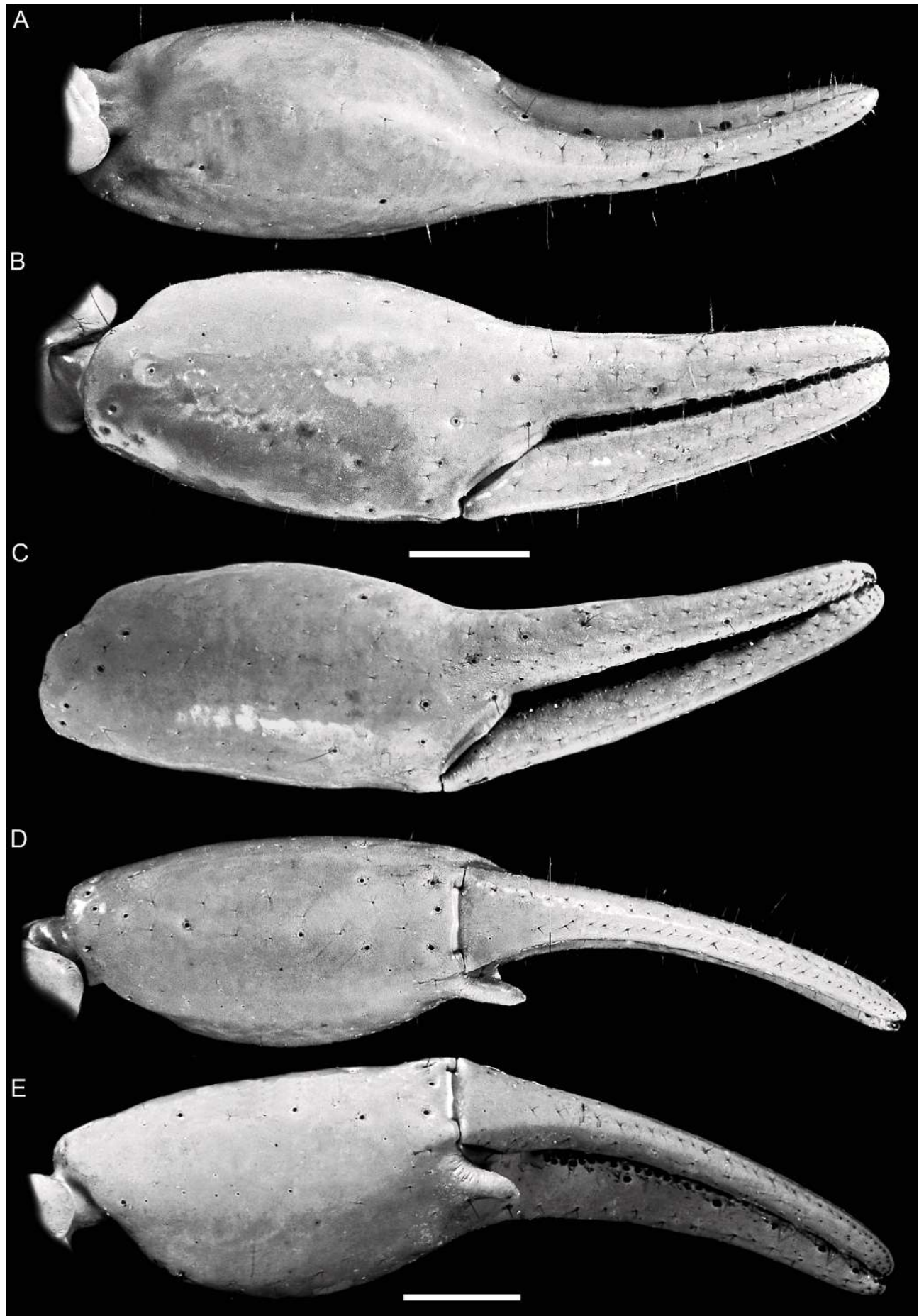

Fig. 39. Orobothriurus huascaran, n. sp., dextral pedipalp chela. A, B. Paratype $q$ (MACN-Ar). C-E. Paratype of (MACN-Ar). A. Dorsal aspect. B, C. External aspect. D. Ventral aspect. E. Ventrointernal aspect. Scale bars $=1 \mathrm{~mm}$. 

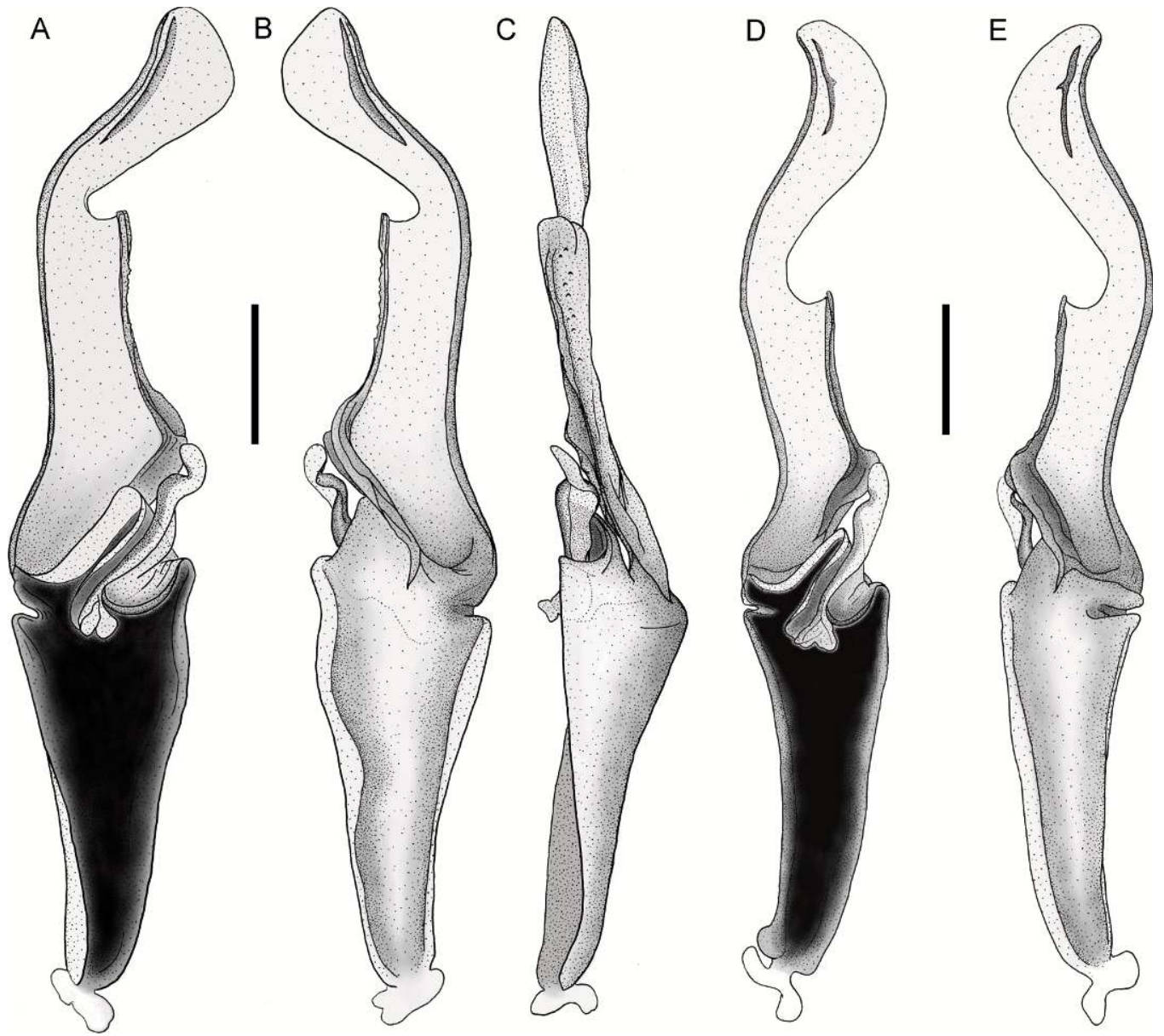

Fig. 40. Orobothriurus Maury, 1976, sinistral hemispermatophores. A-C. Orobothriurus huascaran, n. sp., paratype of (MACN-Ar). D, E. Orobothriurus quewerukana, n. sp., paratype of (MACN-Ar). A, D. Ental aspect. B, E. Ectal aspect. C. Dorsal aspect. Scale bar $=1 \mathrm{~mm}$.

Arthropod surveys conducted using pitfall traps in the summers of 2004 and 2006 did not collect other scorpion species. A recent expedition to the area confirmed that this species is the only scorpion present and active during the summer at this altitude on the El Nevado volcano. All specimens were collected at night in rocky areas (mostly basalt and pumice), and efforts to find the species on sandy slopes (with ash and pumice fragments) surrounding these rocky habitats were unsuccessful. Despite the harsh conditions, with very low temperatures and strong winds during the night, the species is apparently active on the surface from midNovember to the end of April.
Orobothriurus huascaran, n. sp.

Figures 4D, 11C, 12A, 14D, 19D, 21F, 22D, 23D, 24C, 37-39, 40A-C, 52; table 3

Orobothriurus crassimanus: Polis, 1990: 252; Lourenço, 1997: 588 (part); Coddington and Colwell, 2001: 207; Lourenço, 2002: 400; 2003: 227; Lourenço and Qi, 2006: 290. [misidentification].

Orobothriurus paessleri: Lourenço and Dastych, 2001: 54 (part) [misidentification: 1 q, from Quebrada Yanganuco].

Orobothriurus sp. 2: Ochoa, 2004a: 50, 73, figs. 1, $2,14,21$, table 1 .

Type Material: PERU: Ancash Department: Huaraz Province: Holotype ô (MHNC), Cordillera Blanca, Huascarán National Park, 


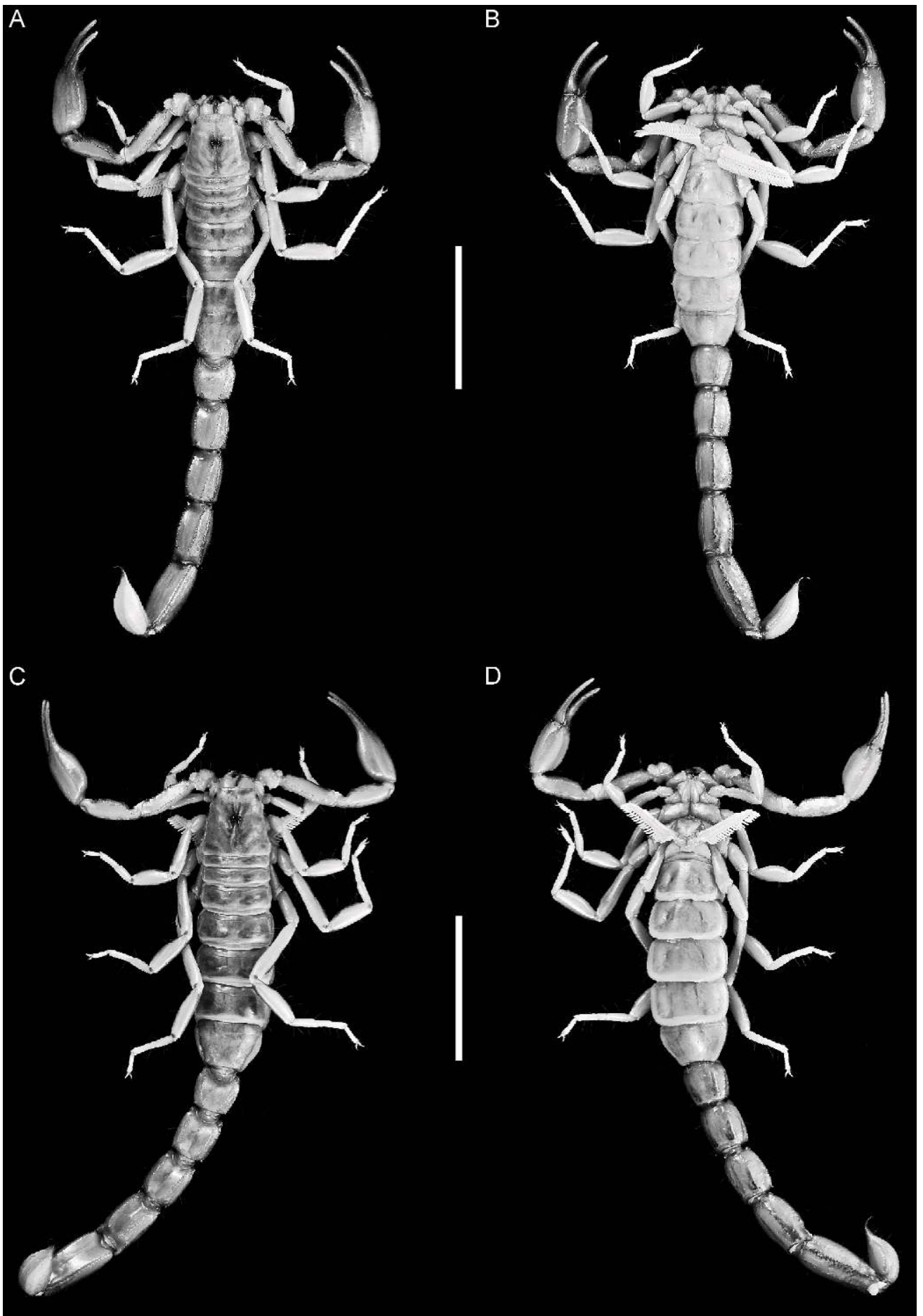

Fig. 41. Orobothriurus quewerukana, n. sp., habitus. A, B. Holotype $\delta$ (AMNH). C, D. Paratype $q$ (MHNC). A, C. Dorsal aspect. B, D. Ventral aspect. Scale bars $=10 \mathrm{~mm}$. 
"ี

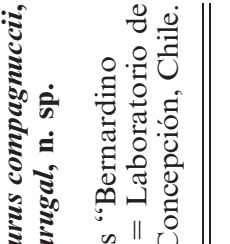

อิ

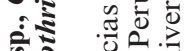

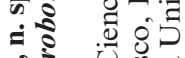

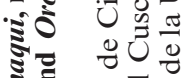

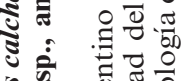

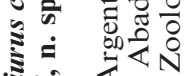

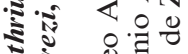

เัต

○ $\Sigma$

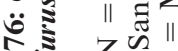

논

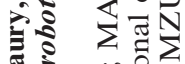

药

노 के

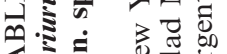

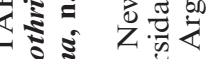

ถ

तें

을

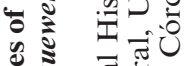

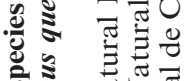

क ज

年

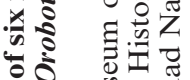

के ${ }^{2} 0 . \frac{\pi}{0}$

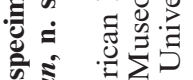

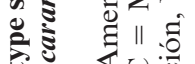

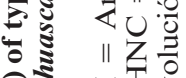

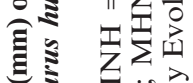

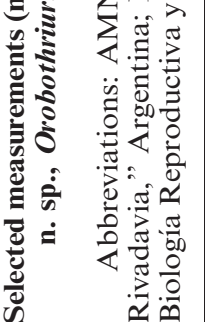

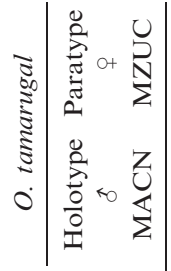

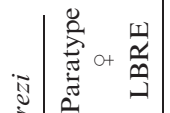

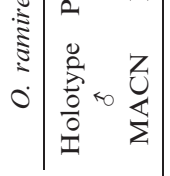

空

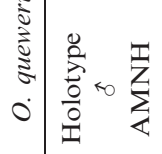

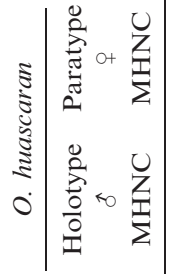

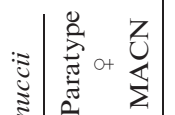

:

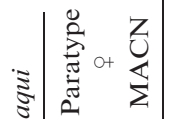

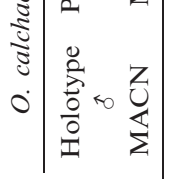

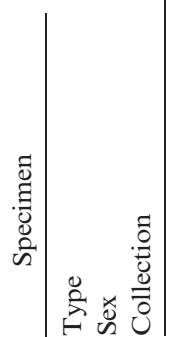

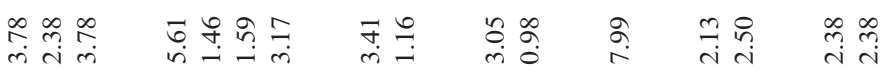

ते

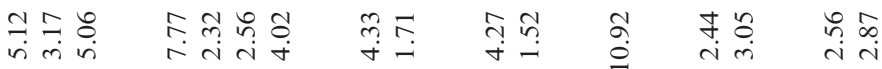

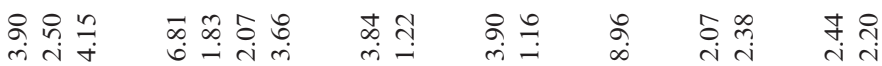

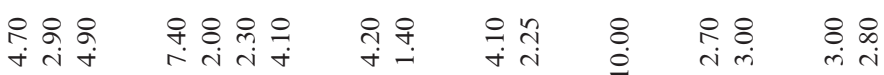

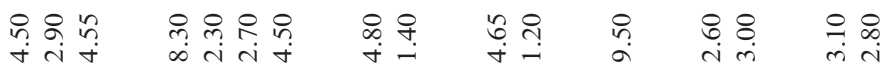

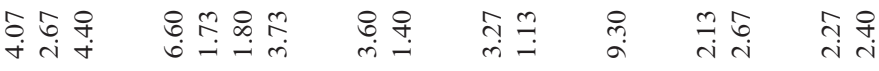

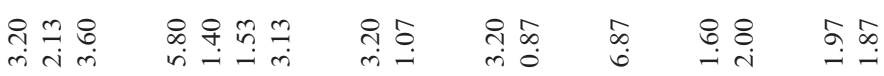

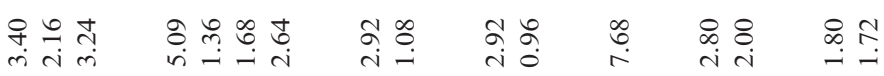

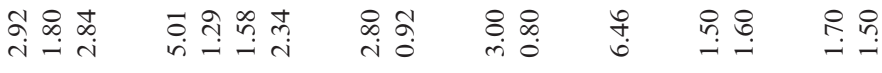

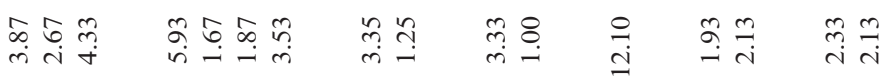

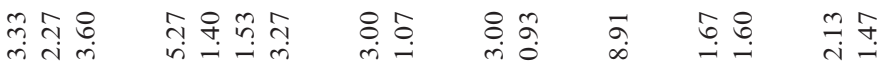

$\frac{5}{5} \frac{0}{3}$

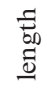

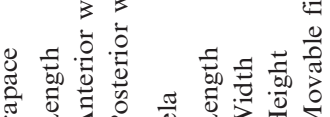

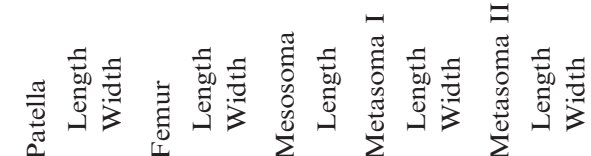




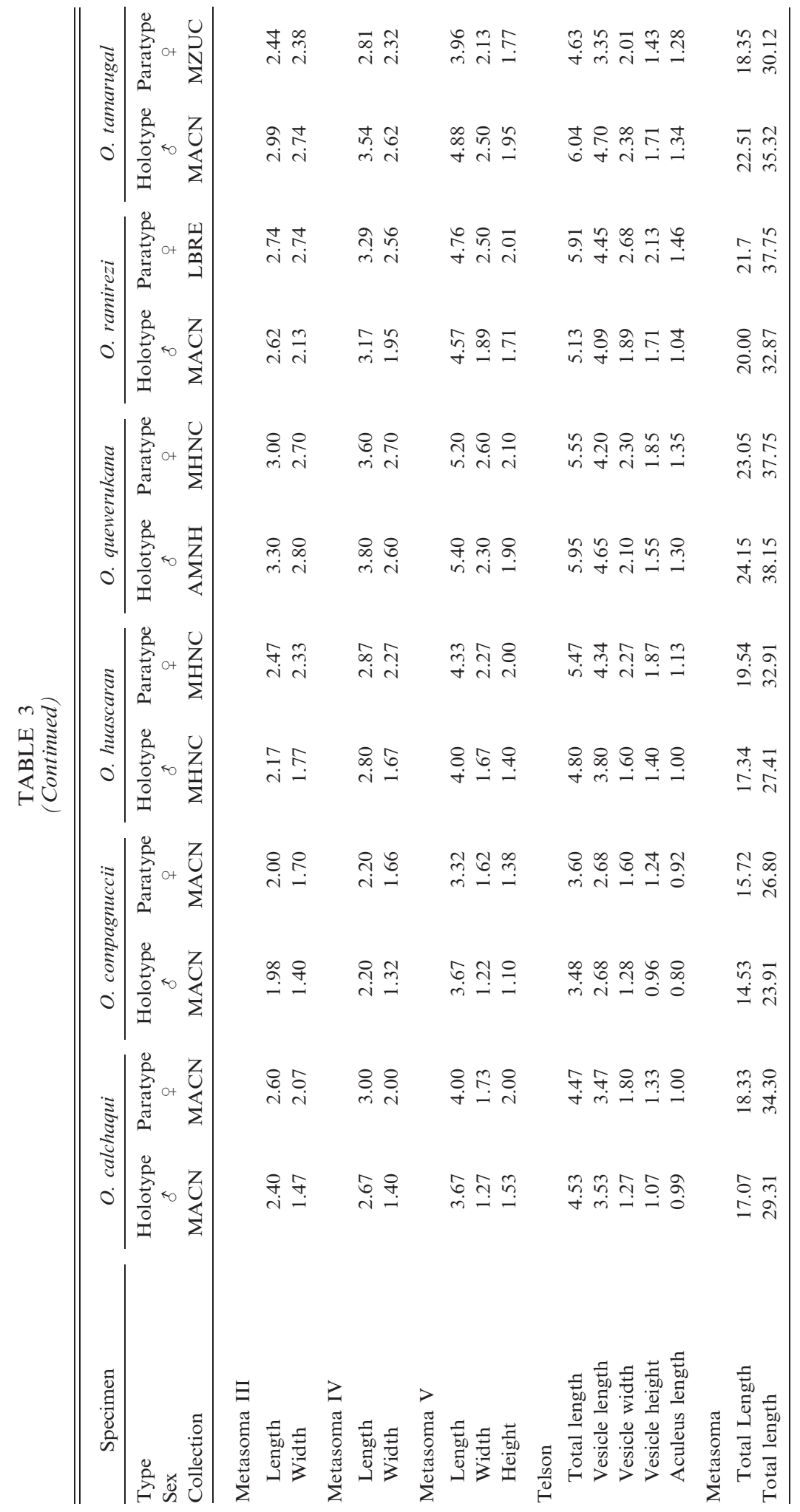


Ishinca, $09^{\circ} 22^{\prime} 49^{\prime \prime} \mathrm{S} \quad 77^{\circ} 27^{\prime} 39^{\prime \prime} \mathrm{W}, 4100 \mathrm{~m}$, 19.vi.1998, J.A. Ochoa. Paratypes: Huaraz Province: Cordillera Blanca, Huascarán National Park, Ishinca, from $09^{\circ} 22^{\prime} 49^{\prime \prime} \mathrm{S} 77^{\circ} 27^{\prime}$ $39^{\prime \prime} \mathrm{W}, 4050 \mathrm{~m}$, to $09^{\circ} 22^{\prime} 28^{\prime \prime} \mathrm{S} 77^{\circ} 24^{\prime} 36^{\prime \prime} \mathrm{W}$, 4910 m, 18-19.vi.1998, J.A. Ochoa, 3 s, 3 ㅇ․ 2 juv. ô (MHNC); Quebrada Querococha,

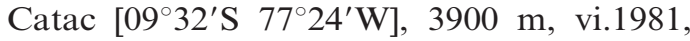
W.R. Lourenço, 1 sं, 2 † (MHNG); Querococha, $3850 \mathrm{~m}$, 16.iii.1994, M. Etonti, 1 § (MRSN); Pastoruri [09 51'S $\left.77^{\circ} 12^{\prime} \mathrm{W}\right]$, 4900 m, 18.iii.1994, M. Etonti, 1 ô (MRSN). Huaylas Province: Laguna Parón [08 59’43"S $77^{\circ} 40^{\prime} 41^{\prime \prime} \mathrm{W}, 4160 \mathrm{~m}$ ], 16.v.2010, R. Pinto da Rocha and D. Silva, 2 s (MZSP), 1 s, 1 ㅇ (MUSM), 2 juv. (AMNH [LP 10709, 10713]). Yungay Province: Llanganuco, $4000 \mathrm{~m}$, 2.i.1976, O. F. Francke, 1 s, 5 ㅇ (MACNAr 17889); same locality, 3600-3850 m, 15.iii.1994, M. Etonti, 2 + (MRSN); same locality, 3810 m, vi.1997, F. Pribik, 1 ㅇ, 1 juv. (FKPC); Llanganuco, Huascarán National Park, $09^{\circ} 04^{\prime} 42^{\prime \prime} \mathrm{S} 77^{\circ} 38^{\prime} 57^{\prime \prime} \mathrm{W}, 3800-4000 \mathrm{~m}$, 28-29.ix.1998, J.A. Ochoa, Polylepis forest, $1 \hat{\delta}, 3$ o paratypes (MHNC), 1 sं, 1 ㅇ $(\mathrm{AMNH}), 1$ $\delta, 1$ ㅇ (LBRE); Chinancocha, Llanganuco, $09^{\circ} 04^{\prime} 18^{\prime \prime} \mathrm{S} 77^{\circ} 38^{\prime} 38^{\prime \prime} \mathrm{W}, 3844 \mathrm{~m}$, 15.v.2010, R. Pinto da Rocha and D. Silva, 1 ㅇ (MZSP).

Additional Material: PERU: Ancash Department: Carhuaz Province: Huascarán National Park, Aquilpo, Porganillo, 09 $19^{\prime}$ $02^{\prime \prime} \mathrm{S} 77^{\circ} 27^{\prime} 32^{\prime \prime} \mathrm{W}, 3730 \mathrm{~m}, 15 . v i .1998$, J.A. Ochoa, 1 sิ, 3 ㅇ, 2 juv. $\delta$, 1 juv. + (MHNC). Huaraz Province: Cordillera Blanca, Huascarán National Park, Ishinca ravine, 09 $22^{\prime} 49^{\prime \prime} \mathrm{S} 77^{\circ} 27^{\prime} 39^{\prime \prime} \mathrm{W}, 4100 \mathrm{~m}, 19 . v i .1998$, J.A. Ochoa, 1 s, 3 juv. (MHNC). Huaylas Province: Laguna Parón [08 59'58'S 7741'09"W, $4180 \mathrm{~m}$ ], ii.1981, W.R. Lourenço, 1 juv. \& (MHNG). Recuay Province: Huama, 4200 m, 22.viii.1972, P. Brignoli, 6 우 [mislabeled "2 $\hat{\delta}, 4$ क’], 14 first instar juv. (MHNG). Yungay Province: Llanganuco, 4300 m, ii.1981, W.R. Lourenço, 3 o (MHNG), 4400-5500 $\mathrm{m}$ [see discussion on the altitude record in Scorpiones], ii.1981, W.R. Lourenço, 2 q (MHNG); Llanganuco, Huascarán National Park, 09 04'42"S $77^{\circ} 38^{\prime} 57^{\prime \prime} \mathrm{W}, \quad 3800-4000 \mathrm{~m}, \quad 28-29 . i x .1998$, J.A. Ochoa, Polylepis forest, 1 ई , 2 o (MHNC).

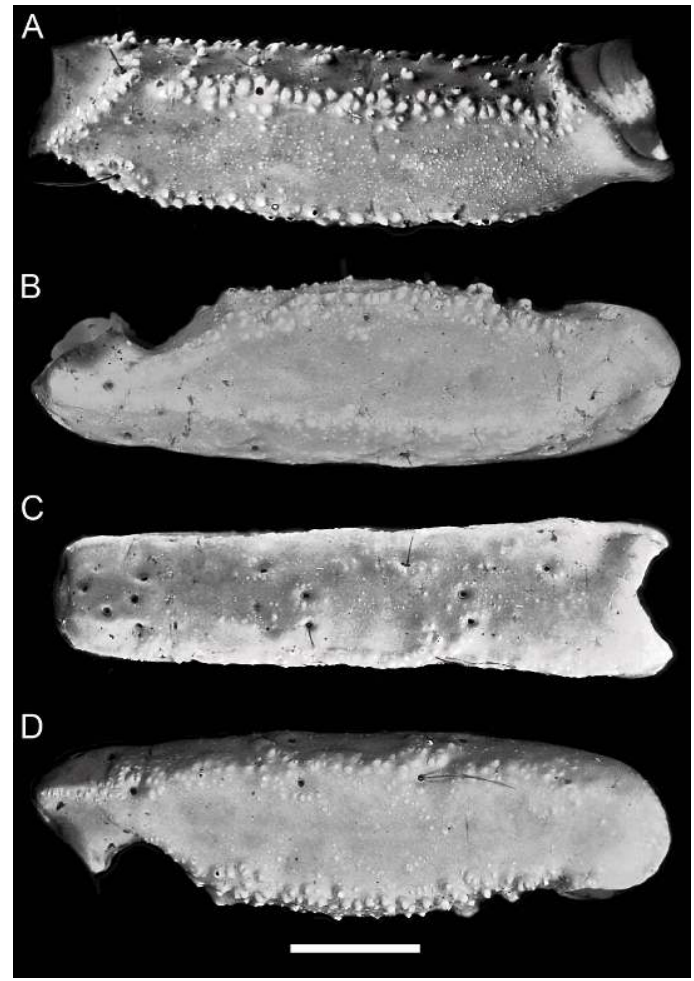

Fig. 42. Orobothriurus quewerukana, n. sp., paratype oै (MHNC), dextral pedipalp femur (A) and patella (B-D). A, B. Dorsal aspect. C. External aspect. D. Ventral aspect. Scale bar $=1 \mathrm{~mm}$.

ETYMOLOGY: The specific name is a noun in apposition derived from the Huascarán National Park, Ancash Department, central Peru, where the type locality of this species is situated. This area belongs to the Cordillera Blanca, the world's highest tropical mountain range.

DiAgNOSIS: Orobothriurus huascaran may be distinguished from other species of the genus by the following combination of characters. The distal border of the apex of the hemispermatophore is slightly rounded, the internal lateral projection of the frontal crest vestigial, and the external lateral projection well developed in $O$. huascaran (fig. 40A-C) compared to other species in which the distal border of the apex is subtriangular, and both lateral projections of the frontal crest are well developed. Pedipalp chela trichobothrium $D b$ is situated slightly closer to $D t$ than to $E b_{3}$ in $O$. 


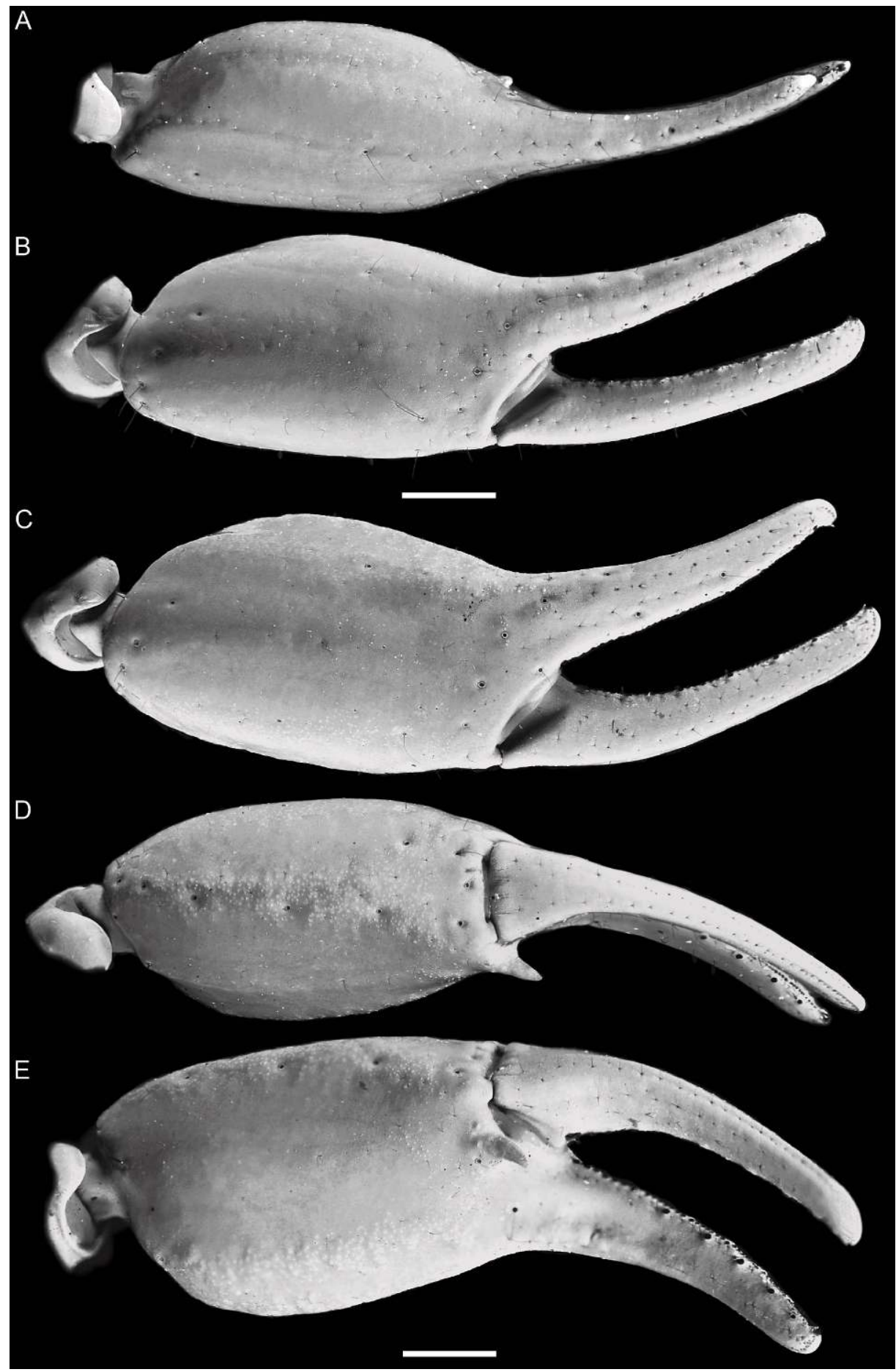

Fig. 43. Orobothriurus quewerukana, n. sp., dextral pedipalp chela. A, B. Paratype 9 (MHNC). C-E. Paratype ô (MHNC). A. Dorsal aspect. B, C. External aspect. D. Ventral aspect. E. Ventrointernal aspect. Scale bar $=1 \mathrm{~mm}$. 

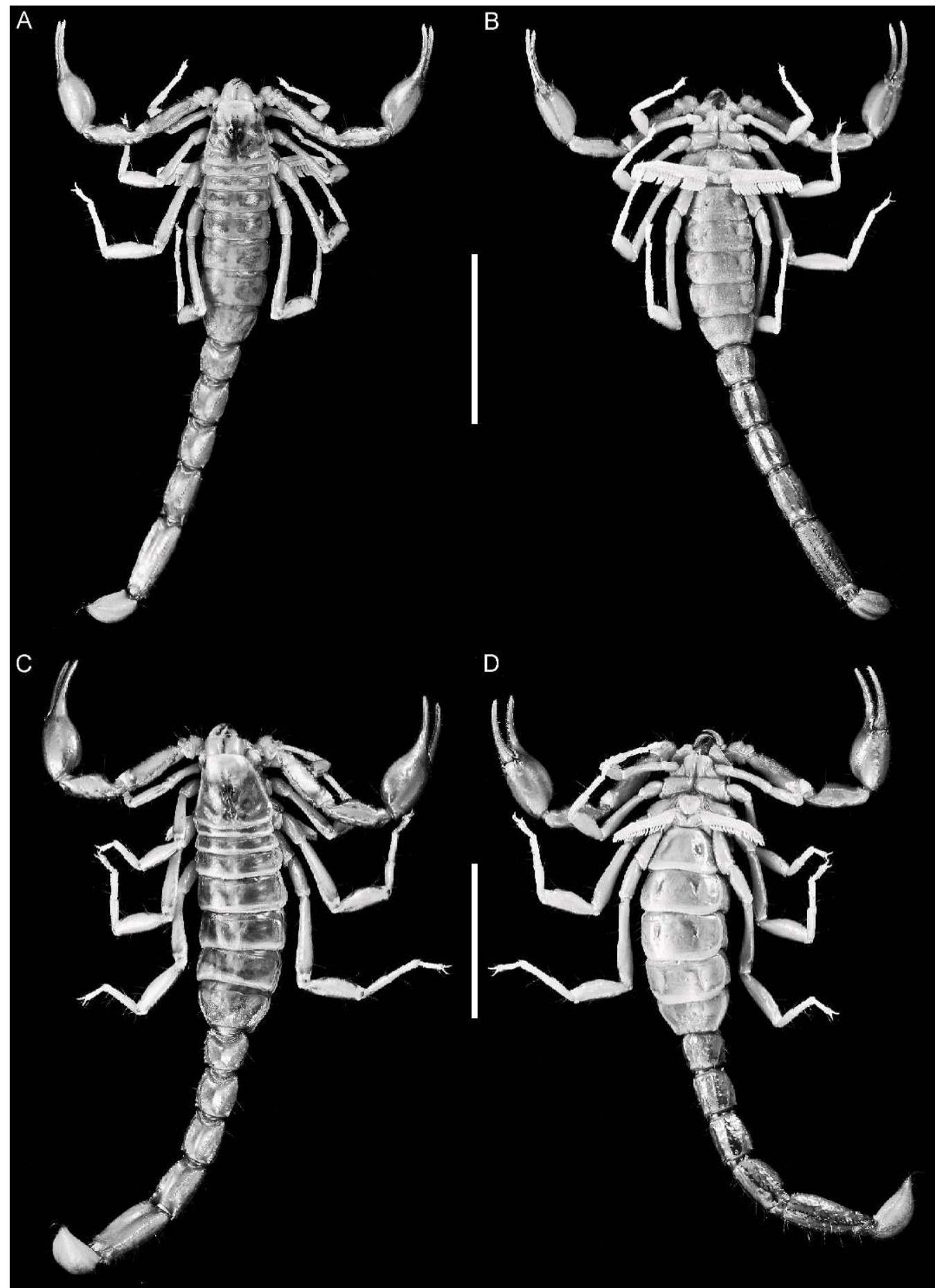

Fig. 44. Orobothriurus ramirezi, n. sp., habitus. A, B. Paratype ô (MACN-Ar). C, D. Paratype $q$ (MACN-Ar). A, C. Dorsal aspect. B, D. Ventral aspect. Scale bars $=10 \mathrm{~mm}$. 
huascaran (fig., 39C), but equidistant between $D t$ and $E b_{3}$ in other species. The VM and VL carinae are restricted to the posterior two-thirds of metasomal segment $\mathrm{V}$ in $O$. huascaran (fig. $21 \mathrm{~F}$ ), absent in $O$. wawita and complete in all other species. Orobothriurus huascaran is similar to four other Peruvian species, $O$. atiquipa, $O$. curvidigitus, $O$. paessleri, and $O$. quewerukana, in several respects. Pedipalp chela trichobothrium $E t_{3}$ is situated proximal to Est, and Esb situated between $E b_{2}$ and $E b_{3}$ in all these species, except $O$ atiquita, in which $E s b$ is situated dorsal to $E b_{2}$. The hemispermatophore of these species exhibits an elongated frontal crest, with a strongly curved, S-shaped apex and a basal lobe with a well-developed terminal process. Orobothriurus huascaran may be distinguished by the presence of VM and VSM carinae on sternite VII and metasomal segment I (fig. 19D), which are absent in $O$. atiquipa, $O$. curvidigitus, $O$. paessleri, and $O$. quewerukana (figs. 18A, 19A, C). Additionally, the pedipalp chela movable finger of the male is straight in $O$. huascaran (fig. 39C) and curved in O. curvidigitus, O. paessleri, and $O$. quewerukana (fig. 26B, C, 43C).

DESCRIPTION: Based on holotype $\hat{\delta}$ and paratypes. Measurements of holotype $\hat{s}$ and paratype $q$ recorded in table 3 .

Total length: o, 26.43-30.79 $\mathrm{mm}(n=9$, mean $=27.97 \mathrm{~mm})$; + , $30.05-33.21 \mathrm{~mm}(n=$ 10 , mean $=31.65 \mathrm{~mm}$ ).

Color: General color yellowish with dark brown spots (fig. 4D). Carapace densely pigmented, especially laterally and posteriorly; anterior margin with narrow stripe (fig. 37A, C); median lateral surfaces densely pigmented; posterolateral surfaces with dense reticulate pigmentation; median ocular tubercle and lateral ocelli dark brown to black; posterior half of anteromedian longitudinal sulcus, median ocular tubercle and anterior half of posteromedian longitudinal sulcus densely pigmented; posterolateral sulci unpigmented. Chelicerae, dorsal surfaces with fine reticulate pigmentation, contiguous distally near base of movable finger; movable finger external surface pigmented. Pedipalp coxa and trochanter faintly pigmented; femur densely pigmented along margins with small unpigmented areas in proximal half; patella densely and irregularly pigmented; chela manus with faint longitudinal stripes along carinae, contiguous at base of movable finger. Legs, femur, and patella densely pigmented prolaterally; tibia and basitarsus faintly pigmented. Tergites I-VI each with two dark spots sublaterally along entire margin and pretergites, delimiting broad, unpigmented median stripe; VII with similar pattern and additional reticulate pigmentation (fig. 12A). Sternum, genital opercula and pectines unpigmented. Sternites III-VI unpigmented, VII with two dark stripes sublaterally (fig. 11C). Metasomal segments I-III, dorsal surfaces each with two subtriangular spots medially, separated by narrow unpigmented line on I, contiguous or separated on II, contiguous on III, becoming broader posteriorly and often connected to median pigmentation by fine reticulate pigmentation, with additional pigmentation along DL carinae; lateral surfaces densely pigmented, especially in anterior half, posterior half with reticulate pigmentation (figs. 11C, 12A); ventral surface with narrow VM stripe, not contiguous with lateral pigmentation, and with two dark VL stripes, becoming broader in posterior half and extending to LIM carinae. Segment IV as for segment III, but with dorsal surface more densely reticulate. Segment V, dorsal surface faintly pigmented along DL carinae; lateral surfaces with dense reticulate pigmentation; ventral surface with three dark stripes, two VL and one VM, becoming slightly broader in posterior half but not contiguous with lateral pigmentation (fig. 11C). Telson vesicle with narrow VM and two broad VL stripes, separated by two narrow unpigmented stripes; aculeus sclerotized, dark reddish-brown.

Chelicerae: Movable finger with two subdistal teeth.

Carapace: Surfaces smooth in anterior third, finely granular elsewhere. Anterior margin linear, without median notch (fig. 14D). Anteromedian longitudinal sulcus complete, well developed, more so in $\hat{\delta}$; median ocular and posteromedian longitudinal sulci well developed; posterolateral sulci obsolete. Median ocular tubercle raised, situated anteromedially; median ocelli two ocular diameters apart. 
Pedipalps: Femur, DI and VI carinae complete, finely granular; DE carina obsolete, smooth (fig. 38A); internal surface finely and sparsely granular medially; other intercarinal surfaces smooth. Patella, DI and VI carinae obsolete, finely granular (\$) or smooth (ㅇ) (fig. 38B-D); internal surface with two prominent granules distally, the larger adjacent to trichobothrium $i$; other intercarinal surfaces smooth. Chela manus slender, fingers relatively elongated (fig. 39); length/width ratio: $\delta, 3.46-4.14(n=11$, mean $=3.76)$, ㅇ, 3.37-4.14 $(n=20$, mean $=$ 3.74); D, DS, DMA, DI, and VM carinae obsolete; intercarinal surfaces smooth; internal surface with acuminate apophysis $(\delta)$ or low bulge ( + ) near articulation of movable finger (fig. 39A, D); fingers, dentate margins each with median denticle row and 4-5 pairs of internal and external accessory denticles.

Trichobothria: Femur with 3 trichobothria, patella with 19, chela with 27 (figs. 38, 39). Chela trichobothrium $E t_{3}$ situated proximal to $E s t ; E s b$ situated between $E b_{2}$ and $E b_{3}$ (fig. 39).

Tergites: Tergites I-VI, surfaces finely granular. Tergite VII tetracarinate, paired DL carinae restricted to posterior two-thirds of segment, paired DSM carinae to posterior half; surfaces more coarsely and densely granular in posterior half.

Legs: Femur and patella, prolateral surfaces finely granular, retrolateral surfaces smooth. Femur, ventral carinae weakly developed; other carinae absent. Patella acarinate. Telotarsi, pro- and retroventral rows of spiniform macrosetae with following counts on leg I, 1/1; II, 2/2; III and IV, 3/3.

Pectines: Pectinal tooth count: $\delta, 17-20$ $(n=30$, mode $=18) ;$ i , $14-17(n=56$, mode $=15)$.

Sternites: Sternites III-VI, surfaces smooth; spiracles small, narrow. Sternite VII, surface smooth in anterior half, granular in posterior half; VL and VSM carinae well developed ( $q$, fig. 19D) or obsolete (indistinct from granulation) to absent $(\hat{\delta})$.

Metasoma: Segment I, DL carinae complete, more developed in $q$; usually one pair of DL macrosetae; ML carinae complete; two pairs of ML setae; LIM carinae obsolete, entirely smooth or with few granules in posterior third; VL and VSM carinae com-

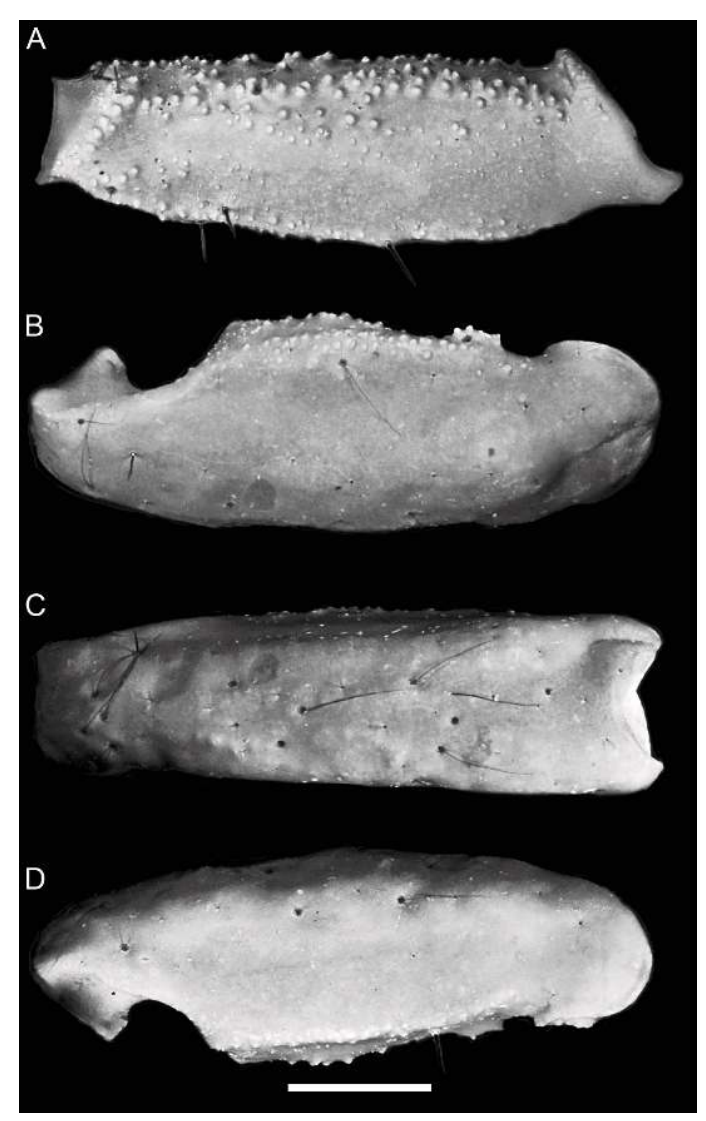

Fig. 45. Orobothriurus ramirezi, n. sp., paratype $\delta$ (MACN-Ar), dextral pedipalp femur (A) and patella (B-D). A, B. Dorsal aspect. C. External aspect. D. Ventral aspect. Scale bar $=1 \mathrm{~mm}$.

plete, obsolete, smooth (\$) or granular ( $(+)$; three pairs of VL and two or three pairs of VSM macrosetae (fig. 19D). Segments II and III, DL carinae complete; one pair of DL macrosetae; ML carinae restricted to posterior half ( $\hat{\delta})$ or complete but less developed than on segment I ( + ); two pairs of ML macrosetae; LIM carinae reduced to one or two granules posteriorly ( $(q)$ or absent ( $\hat{\delta}$ ) on segment II, absent on III; VL carinae as for segment I, but less developed ( + ) or absent ( $\delta$ ) on II, obsolete (q) or absent ( $\delta$ ) on III; VSM carinae as for segment I, but less developed on II, obsolete (q) or absent ( $\hat{\sigma}$ ) on III; three pairs of VL and VSM macrosetae. Segment IV, DL carinae complete; one or (usually) two pairs of DL macrosetae; ML carinae reduced to few small granules poste- 


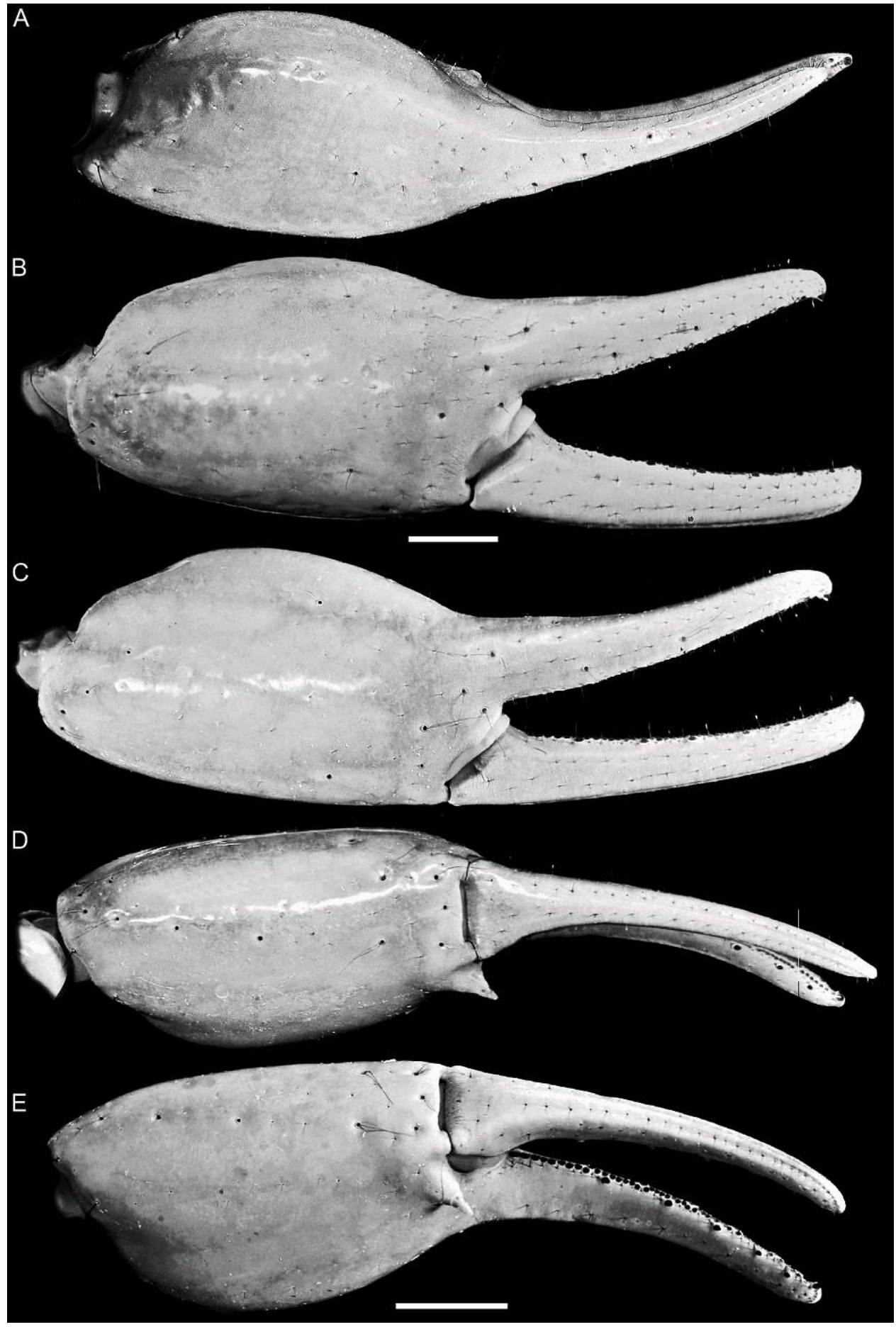

Fig. 46. Orobothriurus ramirezi, n. sp., dextral pedipalp chela. A, B. Paratype + (MACN-Ar). C-E. Paratype ô (MACN-Ar). A. Dorsal aspect. B, C. External aspect. D. Ventral aspect. E. Ventrointernal aspect. Scale bar $=1 \mathrm{~mm}$. 

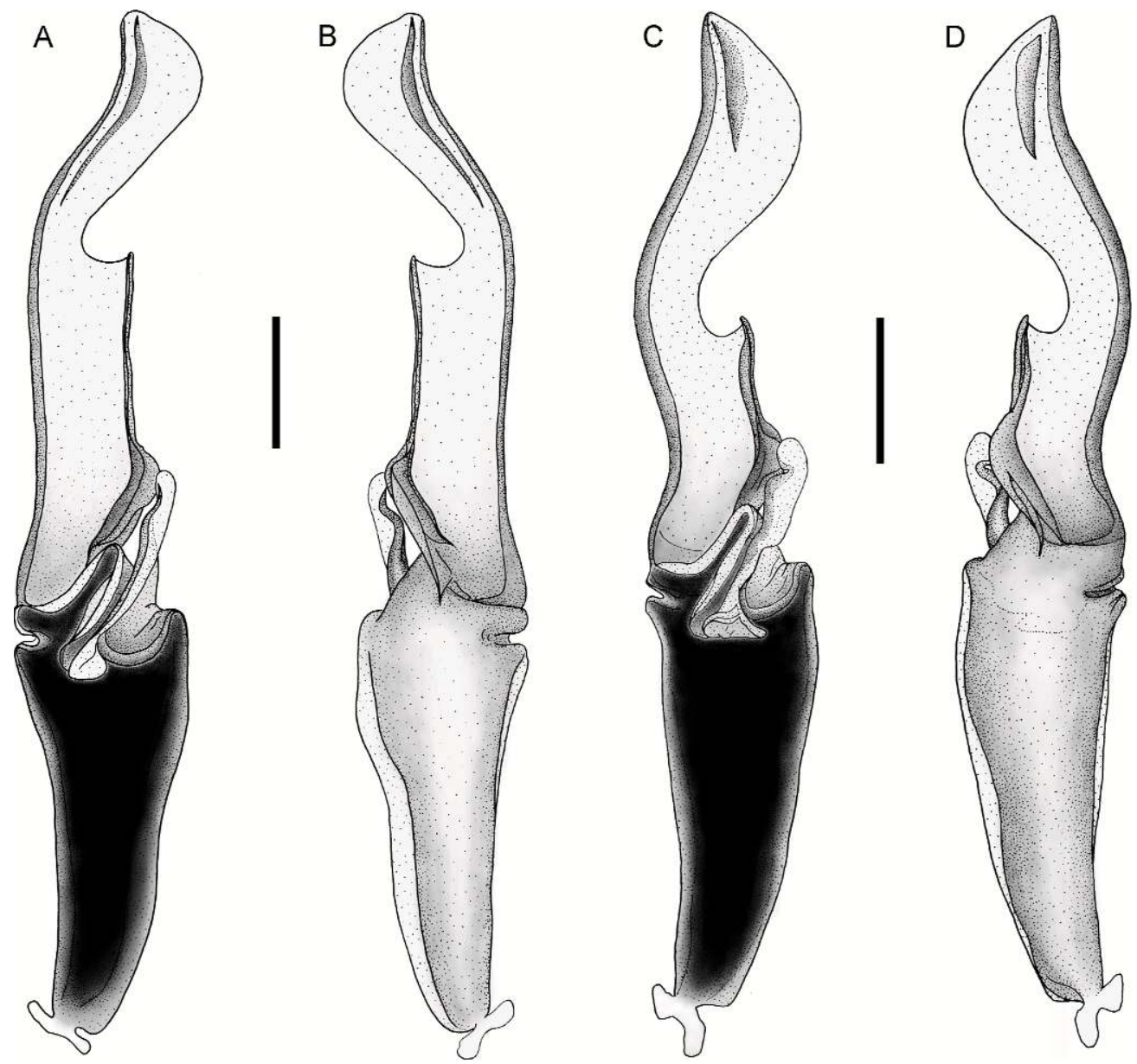

Fig. 47. Orobothriurus Maury, 1976, sinistral hemispermatophore. A, B. Orobothriurus ramirezi, n. sp., paratype $\delta$ (MACN-Ar). C, D. Orobothriurus tamarugal, n. sp., holotype $\delta$ (MACN-Ar). A, C. Ental aspect. B, D. Ectal aspect. Scale bar $=1 \mathrm{~mm}$.

riorly; LIM carinae absent; VL and VSM carinae absent; three pairs of VL and four pairs of VSM macrosetae. Segment V, length/ width ratio: $\delta, 2.07-2.40(n=5$, mean $=$ $2.17)$, ㅇ, $1.71-2.02(n=7$, mean $=1.87)$; DL carinae reduced to three or four prominent granules anteriorly; lateral intercarinal surfaces smooth (ठ) ) or finely and sparsely granular medially near VL carinae $(+)$; VL carinae usually restricted to posterior twothirds (but complete, weakly granular in anterior third in some of), with terminal granules more developed; VSM and VM carinae usually obscured by surface granulation in posterior two-thirds (fig. $21 \mathrm{~F}$ ), but
VM carinae faintly evident in some $q$ (fig. 21D); four pairs of VL and VSM macrosetae; two pairs of macrosetae along posterior margin; ventral intercarinal surfaces densely granular in posterior two-thirds, more so in $q$, granules more acute in $\delta$.

Telson: Length/height ratio: $\hat{\delta}, 2.86-3.52$ $(n=11$, mean $=3.24)$; ; , 2.61-3.39 $(n=19$, mean $=3.04)$. Vesicle slightly elongated $(\hat{\delta}$, fig. 23D) or globose ( + , fig. 24C); dorsal surface smooth, flat, gland not apparent $(\hat{\delta})$; ventral surface smooth $(\delta)$ or granular in anterior third ( + ). Aculeus short and curved.

Hemispermatophore: Apex shorter than frontal crest, distal border slightly rounded; 

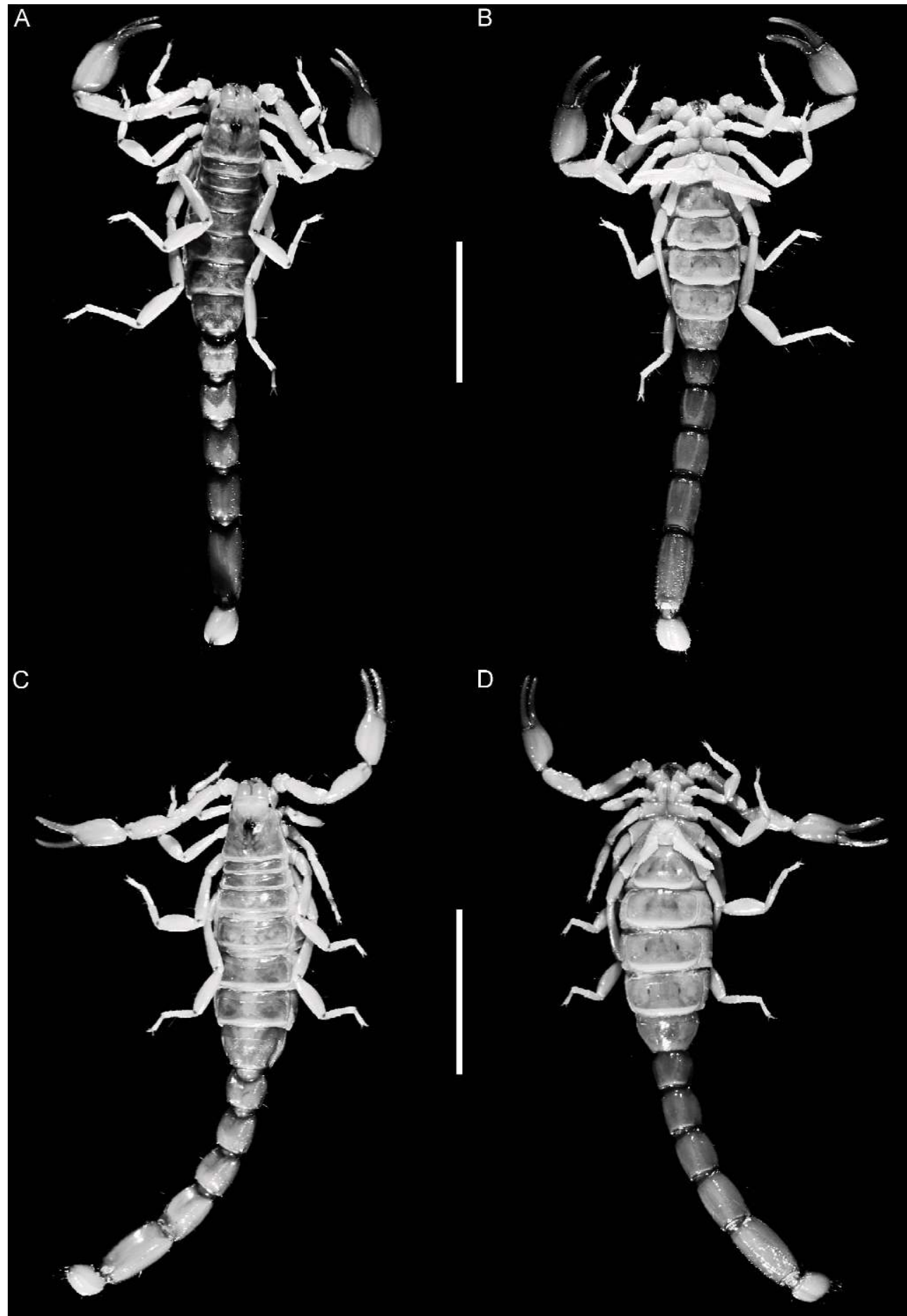

Fig. 48. Orobothriurus tamarugal, n. sp., habitus. A, B. Holotype of (MACN-Ar). C, D. Paratype $q$ (LBRE). A, C. Dorsal aspect. B, D. Ventral aspect. Scale bars $=10 \mathrm{~mm}$. 
distal crest curved like ventral margin. Frontal crest elongated; basal part oblique; distal part parallel to ventral margin of lamina, lateral projections slightly undulated and larger than basal part, ental lateral projection vestigial, ectal lateral projection complete. Basal lobe, terminal process extending to constriction of frontal crest (fig. $40 \mathrm{~A}-\mathrm{C}$ ).

DISTRIBUTION: Orobothriurus huascaran is endemic to the Ancash Department of central Peru (fig. 52). All known localities of this species occur in the Cordillera Blanca mountain range of the western Andes, the world's highest tropical mountain range (fig. 3F). This species has been collected from $3730 \mathrm{~m}$ (Porganillo, trekking route to Aquilpo mountain) to $4910 \mathrm{~m}$ (Ishinca ravine). It is present above $4050 \mathrm{~m}$ in the Ishinca area, but more abundant at $4100 \mathrm{~m}$; only four specimens were found above $4500 \mathrm{~m}$. The record of this species from Laguna Parón is currently the northernmost record for the genus Orobothriurus. The record from the Ishinca ravine is the world's highest record for a scorpion.

ECOLOGY: The area inhabited by $O$. huascaran represents typical Puna vegetation with shrub steppe, grasses and small patches of Polylepis spp. forest ("queñua" in Quechua), situated at 3800-4200 m (fig. 3F). All specimens were found under stones during the day. No other scorpion species have been recorded in the area.

REMARKS: The female specimen from Quebrada Yanganuco, listed under $O$. paessleri by Lourenço and Dastych (2001: 54), is probably conspecific with $O$. huascaran, n. sp., based on the known distribution of this species.

Orobothriurus paessleri (Kraepelin, 1911)

Figures 13A, B, 15A, 19B, 21B, 22B, 26B, $28 \mathrm{C}, \mathrm{E}, 53$

Bothriurus paessleri Kraepelin, 1911: 91, 98, 99, figs. 8, 9a, 9b; Mello-Leitão, 1931: 92; 1932: 34; 1934: 63; 1945: 181; Bücherl, 1953: 117; Aguilar and Meneses, 1970: 2; Maury, 1973: 110.

Bothriurus (Andibothriurus) paessleri: Bücherl et al., 1963: 216.

Orobothriurus paessleri: Maury, 1976: 19, 20, figs. 25-33, table I; 1981: 105; Francke, 1977: 75; Kovařík, 1998: 101; Acosta and Ochoa, 2000: 136, 143; Lowe and Fet, 2000: 36; Acosta and Ochoa, 2001: 205; Ochoa and Acosta, 2002a:
102, fig. 9; Ochoa, 2004a: 52, 55, 73, figs. 1, 2, 21, table 1; Ochoa, 2005: 55, figs. 7, 10, table 2.

Orobothriurus curvidigitus: Lourenço and Dastych, 2001: 54 [misidentification: 3 from Mejía].

Type Material: PerU: Arequipa Department: Islay Province: Syntypes: 1 to, 3 ㅇ (ZMH), "Kataringo" [Catarindo], near Mollendo $\left[17^{\circ} 00^{\prime} 58^{\prime \prime} \mathrm{S} \quad 72^{\circ} 02^{\prime} 03^{\prime \prime} \mathrm{W}, 34 \mathrm{~m}\right.$ ?], 25.ii.1907, R. Paessler.

New Records: PERU: Arequipa Department: Camaná Province: $\mathrm{S}$ of Camaná, 7.viii.1977, L. Peña, 1 \& (MACN-Ar). Islay Province: Lomas de Mejía $\left[17^{\circ} 02^{\prime} \mathrm{S} 71^{\circ} 51^{\prime} \mathrm{W}\right.$, 530 m], 1-3.ii.2000, J.A. Ochoa, 1 ô, 2 ㅇ, 3 juv. (MHNC), 1 ઈ, 1 ㅇ (CDA 168); Lomas de Mejía, Challascapa $\left[17^{\circ} 02^{\prime} \mathrm{S} 71^{\circ} 51^{\prime} \mathrm{W}\right.$, $550 \mathrm{~m}]$, 3.iii.2004, R. Gutierrez and J.A. Ochoa, 2 juv. (AMNH [LP 3057]); near Mejía, $17^{\circ} 07^{\prime} \mathrm{S} \quad 71^{\circ} 55^{\prime} \mathrm{W}, \quad 350-500 \mathrm{~m}$, 15.i.1956, Koepcke, Park loma, Kp 1350, 1 §, 1 subad. के, 2 juv. ô, 2 juv. क (ZMH A18/ 101) [misidentified by W.R. Lourenço as " $O$. curvidigitus"]; Lomas de Yuta, Matarani, $16^{\circ} 57^{\prime} 16^{\prime \prime} \mathrm{S} 72^{\circ} 04^{\prime} 10^{\prime \prime} \mathrm{W}, 570 \mathrm{~m}, 12 . i i i .1998$, E. Ponce and J.A. Ochoa, 1 i (MHNC).

Diagnosis: Orobothriurus paessleri is most closely related to $O$. curvidigitus, $O$. quewerukana and $O$. tamarugal (fig. 5), from which it may be separated as follows. Metasomal segment $\mathrm{V}$ is markedly shorter, its length less than twice its width, in the female of $O$. paessleri (fig. 22B), than in the females of other species, in which its length is greater than or equal to twice its width. Orobothriurus paeslleri possesses three pairs of VSM macrosetae on metasomal segment I (fig. 19B), whereas the other species possess two (fig. 19A). The pedipalp chela movable finger of the male is slightly curved in $O$. paessleri (fig. 26B), but strongly curved in the other species (figs. 26C, 43C, 51A). Orobothriurus paessleri may be further separated from $O$. curvidigitus and $O$. quewerukana by the shape of the lamina of the hemispermatophore (figs. $28 \mathrm{~B}, \mathrm{C}, 40 \mathrm{E}$ ), the frontal crest of which is shorter and less developed in $O$. paessleri (fig. 28E) than in O. curvidigitus and O. quewerukana (fig. 28D). Additionally, the ventral surfaces of metasomal segments I-III are finely granular in O. paessleri (fig. 19B), whereas only the ventral surfaces of segment 
I in males are finely granular in $O$. curvidigitus and $O$. quewerukana.

DisTRIBUTION: Orobothriurus paessleri appears to be endemic to the area near Mejía and Yuta (Matarani) in the Arequipa Department of southern Peru (fig. 53). A single record from Toquepala $\left(17^{\circ} 14^{\prime} \mathrm{S} 70^{\circ} 36^{\prime} \mathrm{W}\right.$, $3000 \mathrm{~m}$ ) in the Tacna Department (Maury, 1976), probably based on a misidentification, requires confirmation.

ECOLOGY: As with $O$. atiquipa, this species has only been collected in Lomas biotopes, isolated patches of green vegetation on hillsides below $1000 \mathrm{~m}$, sustained by coastal fog, and surrounded by hyperarid desert. The Lomas vegetation near Mejía and Yuta is dominated by herbaceous shrubs, e.g., Nolana L.f., Palaua Cav., Portulaca L., Weberbauerella Ulbr., and the tree Caesalpinia spinosa (Molina) Kuntze (Péfaur, 1981; Dávila Flores, 1982).

REMARKS: Specimens of $O$. paessleri from Mejía deposited in the ZMH collection were examined, and found to be misidentified as $O$. curvidigitus by Lourenço and Dastych (2001: 54). Currently two Orobothriurus species have been recorded from Lomas formations: $O$. atiquipa and $O$. paessleri. In addition, we examined a single female deposited at MHNC from Lomas de Sama, southern Peru. This specimen is poorly preserved and difficult to identify with certainty.

Orobothriurus parvus Maury, 1976

Figures 4C, 9, 12B, 17A, 22E, 26A, 27B, 52

Orobothriurus parvus Maury, 1976: 17, 21-23, figs. 45-54, table I; Galiano and Maury, 1979: 327; Maury, 1980: 338, fig. 12; Kovařík, 1998: 101; Acosta and Ochoa, 2000: 136, 143; Lowe and Fet, 2000: 36; Acosta and Ochoa, 2001: 205; Lourenço and Dastych, 2001: 54; Ochoa 2004a: 52, 55, 73, table 1, figs. 1, 2, 21.

Bothriurus borellianus Mello-Leitão, 1934: Bücherl, 1959b: 273 [misidentification].

Bothriurus chilensis (Molina, 1782): Aguilar and Meneses, 1970: 3 [misidentification].

Bothriurus (Andibothriurus) peruvianus MelloLeitão, 1948: Francke, 1974: 217, 218, figs. 15, table 1 [misidentification].

Type Material: PERU: Junín Department: Yauli Province: Holotype of (MACN-Ar 6837), Abra de Anticona, Oroya [11 $36^{\prime} 31^{\prime \prime S}$ 76¹1'48”W], 4750 m, 28.xi.1974, A. Martínez. Paratypes: same data, 1 $\delta$, 1 juv. (MACN-Ar
6838); Acaya, Río Mantaro [1 $\left.11^{\circ} 49^{\prime} \mathrm{S} 75^{\circ} 36^{\prime} \mathrm{W}\right]$, 3480 m, 1.iii.1957, W. Weyrauch, 1 + (IML 388).

New RECORDS: PERU: Junín Department: Jauja Province: Acolla, near Jauja, [11 ${ }^{\circ} 44^{\prime} 17^{\prime \prime} \mathrm{S}$ $\left.75^{\circ} 32^{\prime} 35^{\prime \prime} \mathrm{W}, 3400 \mathrm{~m}\right]$, 8.viii.1953, F. Blancas, 4 , 12 juv. (MUSM), ii.1965, F. Blancas, 2 ㅇ (MUSM). Junín Province: Ondores [11 $\left.{ }^{\circ} 04^{\prime} 06^{\prime \prime} \mathrm{S} 76^{\circ} 09^{\prime} 21^{\prime \prime} \mathrm{W}, 4300 \mathrm{~m}\right]$, 6.v.2000, E. Ponce, 2 8, 7 o (MHNC); Quebrada Antacocha, between Junín and Carhuamayo [11 ${ }^{\circ} 03^{\prime} \mathrm{S} \quad 76^{\circ} 00^{\prime} \mathrm{W}, 4090 \mathrm{~m}$ ], viii.1952, F. Blancas, 1 juv. (MUSM). Tarma Province: Tarma, $2 \mathrm{~km} \mathrm{E}\left[11^{\circ} 24^{\prime} 58^{\prime \prime} \mathrm{S} \quad 75^{\circ} 39^{\prime} 59^{\prime \prime} \mathrm{W}\right.$, $3400 \mathrm{~m}]$, 4.i.1973, N.F. Hadley and O.F. Francke, 1 \& (AMNH). Yauli Province: Casaragra?, xi.1947, H. de Madedo, 1 (MUSM); Cerro Quinan, Tupac Amaru, Yauli, La Oroya [11 ${ }^{\circ} 32^{\prime} \mathrm{S} 75^{\circ} 54^{\prime} \mathrm{W}, 3968 \mathrm{~m}$ ], 26.viii.2005, W. Paredes, 1 ㅇ (MHNC), 1 juv. (AMNH [LP 6257B]).

Diagnosis: Orobothriurus parvus is most closely related to $O$. wawita (fig. 5). Both species share similar hemispermatophore morphology, including an elongated lamina apex and a short frontal crest (fig. 27B, C). The reticulate pigmentation along the metasomal DL carinae (figs. 12B, 13C) and the macrosetal counts on the ventral surface of the metasoma are also similar. The following characters separate the two species. The pedipalp chela manus of the male $O$. parvus possesses an apophysis on the internal surface, and the fixed finger is slightly curved, creating a small gap with the movable finger when the fingers are closed (fig. 26A), whereas the apophysis is absent and the fixed finger straight, such that no gap is evident when the fingers are closed, in the male of $O$. wawita (fig. 25B, C). The VL and VM carinae of metasomal segment $\mathrm{V}$ are complete in $O$. parvus (fig. 22E), but absent ( $\hat{\delta}$ ) or restricted to the distal third of the segment ( 9 ) in O. wawita (figs. 21C, 22F). Metasomal segments II-V exhibit a distinct VM pigmentation stripe in $O$. parvus that is absent in $O$. wawita (fig. 13D). The two species also differ in the shape of the ventral margin of the hemispermatophore apex, which is inclined to the dorsal surface and curved distally in $O$. parvus (fig. 27B), but straight in $O$. wawita (fig. 27C).

DisTRIBUTION: Orobothriurus parvus is endemic to the central Andes, recorded from 
3400-4750 $\mathrm{m}$, in the Junín and Lima departments, Peru (figs. 2E, 52).

ECOLOGY: The area inhabited by $O$. parvus corresponds to the Puna ecoregion or Puna biogeographical province (Brack, 1986; Ceballos Bendezu, 1976). The typical Puna vegetation of this area comprises shrub, steppe, and grasses (fig. 2E). No other scorpion species have been recorded in sympatry with $O$. parvus.

REMARKS: Orobothriurus parvus was misidentified in several papers as Bothriurus borellianus, Bothriurus chilensis or Bothriurus (Andibothriurus) peruvianus (Bücherl, 1959b; Aguilar and Meneses, 1970; Francke, 1974). A record from Colcabamba (Lourenço and Dastych, 2001: 54), based on a single female, requires confirmation.

Orobothriurus quewerukana, n. sp.

Figures 15C, 19C, 20D, 23F, 24D, 40D, E, 41-43, 53; table 3

Orobothriurus dumayi: Maury, 1976: 21, figs. 4044; Acosta and Ochoa, 2000: 136, 143. [misidentification].

Type MATERial: CHILE: Región I (Tarapacá): Parinacota Province: Holotype $\hat{\delta}$

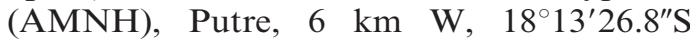
$69^{\circ} 32^{\prime} 47.1^{\prime \prime} \mathrm{W}, 3732 \mathrm{~m}, 16 . i .2005$, A. Ojanguren Affilastro, C.I. Mattoni and J.A. Ochoa, UV and under stones. Paratypes: CHILE: Región I (Tarapacá): Iquique Province: Termas de Mamiña, 8.viii.1967, J.C. Ortiz, 4 juv. (MACN-Ar 6846); Mamiña, 20 04'33.6"S $69^{\circ} 12^{\prime} 05.4^{\prime \prime} \mathrm{W}, 2822 \mathrm{~m}, 19 . i .2005$, A. Ojanguren Affilastro, C.I. Mattoni and J.A. Ochoa, UV and under stones, small wet valley with old terrace cultivation, 2 s, 2 ㅇ, 14 juv. (LBRE), 2 ๙े, 2 ㅇ, 8 juv. (MACN-Ar), 2 ๙े, 1 ㅇ, 1 subad. ㅇ (MHNC), 1 $\delta, 1$ ㅇ, 6 juv. (MZUC). Parinacota Province: same data as holotype, 2 $\delta, 2+$, 6juv. (MACN-Ar), $2 \delta, 1+$, 3 juv. (LBRE), 1 iे, 1 ㅇ, 3 juv. (MHNC), 1 subad. of (AMNH). PERU: Tacna Department: Tacna Province: Palca, $17^{\circ} 46^{\prime} 45^{\prime \prime} \mathrm{S}$ $69^{\circ} 57^{\prime} 04^{\prime \prime} \mathrm{W}, 3230 \mathrm{~m}, 26 . i i .2000$, J.A. Ochoa, 1 ㅇ $(\mathrm{AMNH}), 1$ s, 2 ㅇ (MHNC).

Additional Material: CHILE: Región I (Tarapacá): Iquique Province: Mamiña, $20^{\circ} 04^{\prime} 33.6^{\prime \prime} \mathrm{S} 69^{\circ} 12^{\prime} 05.4^{\prime \prime} \mathrm{W}, 2822 \mathrm{~m}, 19 . \mathrm{i} .2005$, A. Ojanguren Affilastro, C.I. Mattoni, and J.A. Ochoa, UV and under stones, small wet valley with old terrace cultivation, 1 subad. $\hat{\delta}, 1$ subad. + , 2 juv. o 8 , 2 juv. + (AMNH[LP 4307]), 5 juv. (AMNH), 5 juv. (MHNC). Parinacota Province: Putre, $6 \mathrm{~km}$ W, $18^{\circ} 13^{\prime} 26.8^{\prime \prime S}$ $69^{\circ} 32^{\prime} 47.1^{\prime \prime} \mathrm{W}, 3732 \mathrm{~m}, 16 . i .2005$, A. Ojanguren Affilastro, C.I. Mattoni and J.A. Ochoa, UV and under stones, 1 subad. $\delta$, 4 juv. $\delta, 1$ juv. 웅 (AMNH [LP 4306]), 4 juv. (LBRE), 3 juv. (MHNC).

ETYMOLOGY: The specific name is a noun in apposition composed of two Quechua words, quewe, meaning "curved," and rukana, meaning "finger." It refers the strong curvature of the movable finger of the pedipalp chela in the adult male.

DiAGNOSIS: Orobothriurus quewerukana is closely related to $O$. curvidigitus and $O$. tamarugal (fig. 5), with which it shares the following characters: anterior margin of carapace with weak median projection (epistome; figs. 14C, 15C, D); pedipalp chela shape similar, with movable finger strongly curved in male (figs. 26C, 43C, 51A); pedipalp femur and patella more elongated in male than female; sternite VII with VSM carinae absent or obsolete (fig. 19A, C); metasomal segments I-IV with DL and ML carinae complete, granular, and VL carinae obsolete, smooth. Orobothriurus quewerukana may be separated from $O$. tamarugal by the shape of the lamina of the hemispermatophore (figs. 40E, 41D). The pedicel of the apex is narrower, and the frontal crest more developed and elongated in $O$. quewerukana; the ventral border of the distal portion of the apex is slightly curved in $O$. quewerukana, but straight in O. tamarugal; and one or two small folds, observed in the distal crest of $80 \%$ of the specimens of $O$. quewerukana, are absent in the distal crest of $O$. tamarugal. The hemispermatophore of $O$. quewerukana is similar to that of $O$. curvidigitus, except for the slightly shorter frontal crest and the absence of folds in the distal crest (figs. 28B, 40E). The two species may be distinguished by the shape and granulation of the male telson vesicle, which is slightly deeper, with a length/height ratio of 3.59-4.00 (mean = 3.76 ), and granulation on the entire ventral surface (fig. $23 \mathrm{~F}$ ), in $O$. quewerukana, compared with $O$. curvidigitus, in which the length/height ratio is 3.72-4.23 (mean = 3.96) and granulation is present only on the 
anterior third of the ventral surface. The male pedipalp chela carinae are finely and densely granular in $O$. quewerukana and $O$. tamarugal (figs. 43D, E, 51B, C), but finely and sparsely granular to smooth in $O$. curvidigitus. These species may also be separated by the pigmentation pattern. Orobothriurus curvidigitus exhibits well-developed pigmentation on the carapace, tergites, metasoma, and pedipalps (figs. 11B, 12C, 13E), compared to $O$. quewerukana in which the pigmentation, especially that of the carapace and tergites, is faint or barely discernible (fig. 41) and $O$. tamarugal, in which it is absent (fig. 48).

DESCRIPTION: Based on holotype $\hat{\delta}$ and paratypes. Measurements of holotype $\delta$ and paratype $q$ recorded in table 3 .

Total length: ô, 38.09-47.00 $\mathrm{mm}(n=8$, mean $=41.59 \mathrm{~mm})$; + , $37.20-51.50 \mathrm{~mm}(n=$ 8 , mean $=43.35$ ).

Color: General color yellowish with light brown spots on carapace, tergites, and pedipalps; metasomal segments, ventral pigmentation slightly darker, especially in specimens from Palca (fig. 41). Carapace faintly spotted, especially laterally and posteriorly; anterior margin with two spots submedially (fig. 41A, C); posterolateral surfaces faintly pigmented; median ocular tubercle and lateral ocelli dark brown to black; anterior third of anteromedian longitudinal sulcus pigmented along borders; posteromedian longitudinal sulcus faintly pigmented or unpigmented; posterolateral sulci unpigmented. Chelicerae unpigmented. Pedipalp coxa, trochanter and femur usually unpigmented or faintly pigmented along DI and DE carinae (some juveniles); patella external and, usually, internal surfaces faintly spotted; chela unpigmented. Legs, only ventral margin of femur, and dorsal and ventral margins of patella pigmented (unpigmented in some adults). Tergites I-VI each with two faint spots sublaterally, extending along anterior twothirds, becoming broader near anterior margins, delimiting broad, unpigmented median stripe (fig. 41A, C); VII unpigmented (adults) or with two faint spots sublaterally (juveniles). Sternum, genital opercula, pectines and sternites III-VII unpigmented (fig. 41B, D). Metasomal segments I-III, dorsal surfaces each with two faint subtriangular spots medially, separated by narrow unpigmented

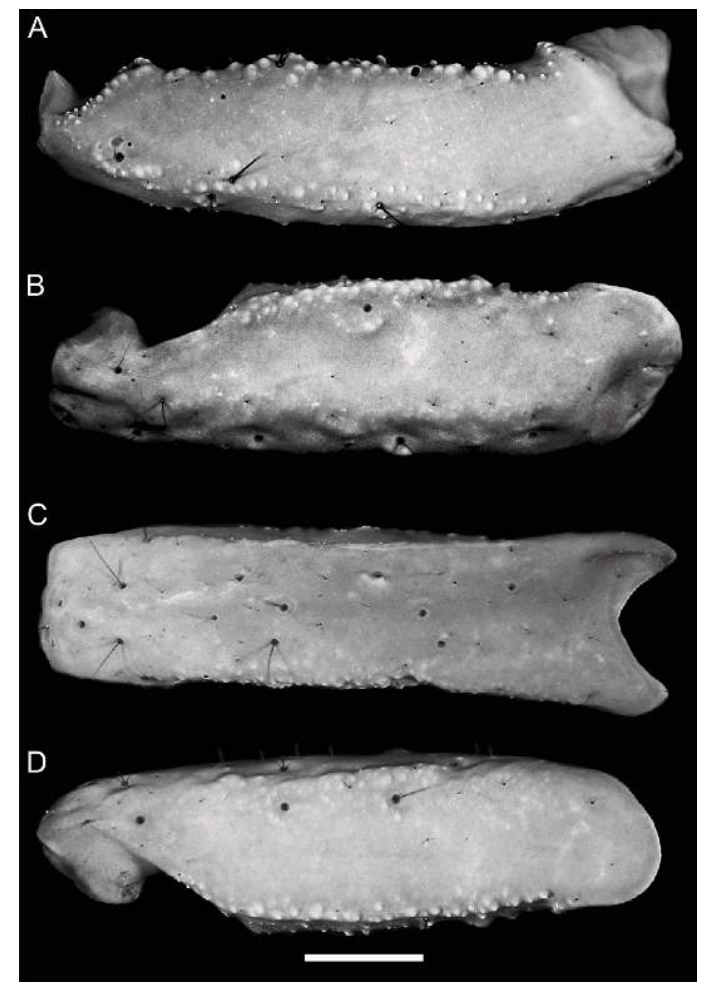

Fig. 49. Orobothriurus tamarugal, n. sp., holotype of (MACN-Ar), dextral pedipalp femur (A) and patella (B-D). A, B. Dorsal aspect. C. External aspect. D. Ventral aspect. Scale bar $=1 \mathrm{~mm}$.

line (juveniles) or unpigmented (adults, fig. 41); lateral surfaces unpigmented, except near VL carinae; ventral surface with narrow VM stripe on III (absent on I and II), not contiguous with lateral pigmentation, and two VL stripes on I-III (occasionally faint or absent on I) becoming broader in posterior third; specimens from Mamiña usually less pigmented: VL stripe absent on segments I and II; VM stripe often absent on III. Segment IV, dorsal surface unpigmented; lateral and ventral surfaces as for segment III. Segment V, dorsal surface unpigmented or faintly pigmented posteriorly; lateral surfaces pigmented in distal third; ventral surface with three stripes, two VL and one VM, becoming slightly broader in posterior half but not joining with lateral pigmentation. Telson vesicle unpigmented or with lateral surfaces faintly pigmented; aculeus sclerotized, dark reddish brown. 


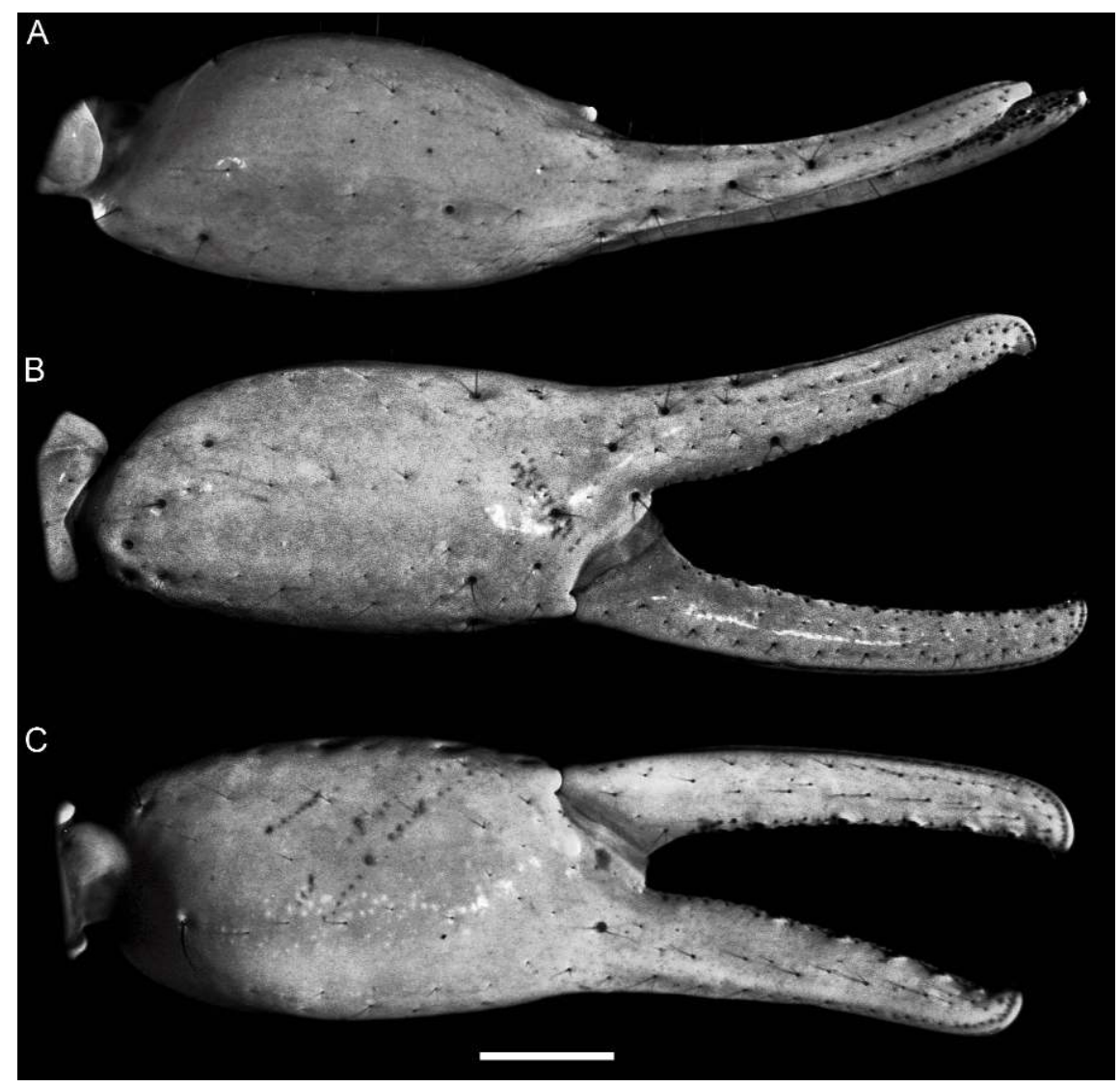

Fig. 50. Orobothriurus tamarugal, n. sp., paratype $q$ (MZUC), dextral pedipalp chela. A. Dorsal aspect. B. External aspect. C. Internal aspect. Scale bar $=1 \mathrm{~mm}$.

Chelicerae: Movable finger with two subdistal teeth.

Carapace: Surfaces finely granular, more coarsely so along anterior margin, anteromedian longitudinal and median ocular sulci (8) or smooth in anterior third, finely granular elsewhere ( $q$ ). Anterior margin with weak median projection (epistome; fig. 14C). Anteromedian longitudinal sulcus complete, moderately developed; median ocular and posteromedian longitudinal sulci well developed; posterolateral sulci obsolete. Median ocular tubercle raised, situated anteromedially; median ocelli two ocular diameters apart.

Pedipalps: Femur, DI, DE, and VI carinae complete (fig. 42A), DI carina more strongly developed than DE and VI carinae; VM carina vestigial, finely granular proximally; EM carina complete, granular $(\hat{\delta})$ or obsolete, finely granular ( $q$, juveniles); dorsal surface finely granular; internal surface sparsely granular medially. Patella, DI, VI, and VE carinae complete, granular (fig. 42B-D); DE carina complete, less developed than DI carina ( $\hat{\sigma})$ or obsolete $(+q)$; EM carina vestigial, reduced to few small granules medially ( $\hat{\sigma}$ ) or absent () ; DPP carina comprising prominent granule and additional small granules proximally; VPP carina vestigial, comprising two or three small granules proximally; internal surface with prominent granule adjacent to trichobothrium $i$ near DI carina. Chela manus slightly rounded, fingers relatively elongated (fig. 43); length/width ratio: $\hat{\delta}, 3.42-4.19,(n=9$, mean $=3.71)$, ㅇ, $3.544 .22(n=6$, mean $=3.87)$; length/height ratio: $\delta, 2.95-3.32,(n=9$, mean $=3.07)$, ㅇ, 2.87-3.34 $(n=6$, mean $=$ 3.16 ); most carinae obsolete, finely granular (less so in +) or absent; VM carina restricted 

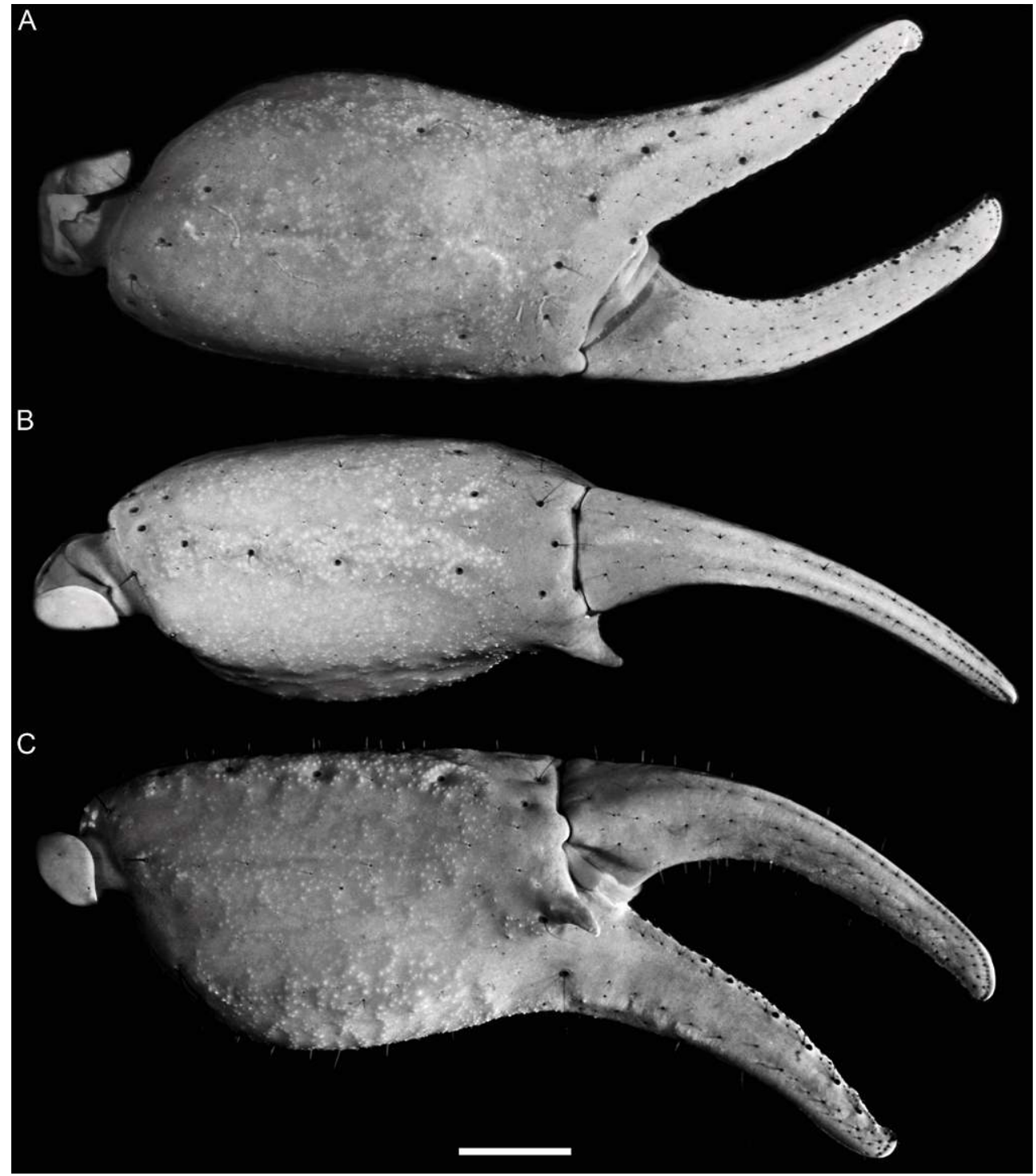

Fig. 51. Orobothriurus tamarugal, n. sp., holotype $\delta$ (MACN-Ar), dextral pedipalp chela. A. External aspect. B. Ventral aspect. C. Ventrointernal aspect. Scale bar $=1 \mathrm{~mm}$.

to proximal two-thirds of manus, VI carina to proximal third; DS, DMA, and DI carinae complete, finely and densely granular, especially near base of fixed finger ( $\delta$ ) or smooth $(+)$; D carina smooth; internal surface with acuminate apophysis $(\hat{\delta})$ or low bulge $(+)$ near articulation of movable finger (fig. 43A, D); movable finger ( $\hat{\delta})$ strongly curved, creating small gap with fixed finger when fingers closed (fig. 43C); fingers, dentate margins each with median denticle row and 4-5 pairs of internal and external accessory denticles.

Trichobothria: Femur with 3 trichobothria, patella with 19, chela with 27 (figs. 42, 43). Chela trichobothrium $E t_{3}$ situated proximal to Est (in same axis as Est in one specimen); $E s b$ situated dorsal to $E b_{2}$.

Tergites: Tergites I-VI, surfaces finely granular, more coarsely and densely so in $\delta$. Tergite VII tetracarinate, paired DL carinae 
restricted to posterior two-thirds of segment, paired DSM carinae to posterior half; surfaces more coarsely and densely granular in posterior half.

Legs: Femur and patella, prolateral surfaces finely granular, retrolateral surfaces smooth. Femur, VI and EM carinae complete in $\hat{\delta}$, less developed in + ; DE and DI carinae vestigial. Patella acarinate. Telotarsi, proand retroventral rows of spiniform macrosetae with following counts on leg I, 1/1; II, 2/2; III and IV, 3/3.

Pectines: Pectinal tooth count: of, 20-24 $(n=34$, mode $=22) ;$ i , $19-22(n=24$, mode $=20$ ).

Sternites: Sternites III-VI, surfaces smooth ( + ) or matt in posterior three-quarters $(\hat{\delta})$; spiracles small, narrow. Sternite VII, surface smooth ( + ) or finely granular ( $\delta$ ) (fig. 19C), acarinate.

Metasoma: Segment I, DL carinae complete; ML carinae complete, posterior granules more prominent than adjacent granulation; one pair of ML macrosetae; LIM carinae reduced to few granules in posterior third; VL carinae obsolete; VSM carinae absent (fig. 19C); two pairs of VL and VSM macrosetae. Segments I and II, ventral intercarinal surfaces finely granular ( $\hat{\delta})$. Segments II-IV, surfaces between DL and ML carinae finely and sparsely granular, granulation decreasing posteriorly. Segments II and III, DL carinae complete; one pair of DL macrosetae in $14 \%$ and $50 \%$ of specimens, respectively; ML carinae as for segment I; LIM carinae reduced to few granules posteriorly on segment II, restricted to posterior third $(\hat{\delta})$ or absent $(q)$ on segment III; VL carinae as for segment I but less developed; VSM carinae absent; three pairs of VL and VSM macrosetae. Segment IV, DL carinae complete, granular; one pair of DL macrosetae; ML carinae complete, granular; LIM carinae absent; VL carinae as for segment III (absent in some subadult and juvenile specimens); VSM carinae absent; usually three pairs of VL and VSM macrosetae. Segment V, length/width ratio: $\delta, 2.18-2.44(n=6$, mean $=2.31)$, ㅇ, 2.01-2.20 $(n=4$, mean $=$ 2.10); DL carinae complete, granular; lateral surfaces sparsely granular near DL carinae (fig. 20D); VL carinae complete; VSM cari- nae reduced to few granules medially; VM carina complete, obscured by surface granulation in posterior half; usually three pairs of VL and VSM macrosetae; two pairs of macrosetae along posterior margin; ventral intercarinal surfaces, granulation decreasing anteriorly.

Telson: Length/height ratio: $\delta$, 3.59-4.00 $(n=9$, mean $=3.76)$; ㅇ, 2.90-3.17 $(n=6$, mean $=3.03)$. Vesicle slightly elongated $(\hat{\delta}$, fig. 23F) or globose ( + , fig. 24D); dorsal surface smooth, flat or slightly concave, gland not apparent $(\hat{\delta})$; ventral surface sparsely granular. Aculeus short and curved.

Hemispermatophore: Apex approximately half the length of lamina, distal border subtriangular and slightly curved to ventral margin; distal crest curved like ventral margin, with one or two small folds in $80 \%$ of specimens. Frontal crest elongated; basal part oblique; distal part parallel to ventral margin of lamina, lateral projections complete, slightly undulated, and larger than basal part. Basal lobe, terminal process extending to constriction of frontal crest (fig. 40D, E).

DISTRIBUTION: Orobothriurus quewerukana is endemic to the western slopes of the Andes, at 2822-3732 $\mathrm{m}$, in the Tacna Department of southern Peru and the Tarapacá Region of northern Chile (fig. 53).

ECOLOGY: The area inhabited by $O$. quewerukana belongs to the Serrania Esteparia ecoregion (Brack, 1986) or Estepa Altoandina botanical region (Gajardo, 1993), the vegetation of which is characterised by abundant cacti and some shrubs, like Baccharis L., Lupinus L., and Senecio L. Specimens were collected under stones during the day and with UV light detection at night. Orobothriurus quewerukana is sympatric with another bothriurid, Brachistosternus quiscapata Ochoa and Acosta, 2002, at Palca and Putre.

Orobothriurus ramirezi, $\mathrm{n}$. $\mathrm{sp}$.

Figures 16A, B, 18C, 20C, F, 21G, 24E, 44 46, 47A, B, 54; table 3

Type Material: CHILE: Region IV (Coquimbo): Elqui Province: Holotype ôे (MACN-Ar), Paso del Agua Negra, between Juntas and international border, $30^{\circ} 12^{\prime} 11.5^{\prime \prime} \mathrm{S}$ $69^{\circ} 54^{\prime} 57.5^{\prime \prime} \mathrm{W}, 3734$ m, 27.i.2005, C.I. Mat- 
toni and A. Ojanguren Affilastro, UV detection, specimens walking actively near a "vega" (small stream), extremely wet. Paratypes: same data, 4 ô, 1 ㅇ (AMNH), 2 s, 1 ㅇ (LBRE), 1 के, 1 ㅇ (MACN-Ar), 1 के (MHNC); same data, except $30^{\circ} 16^{\prime} 14.5^{\prime \prime} \mathrm{S} 69^{\circ} 58^{\prime} 27.9^{\prime \prime} \mathrm{W}$, $3295 \mathrm{~m}, 1$ o, 1 ㅇ, 5 juv. (AMNH), 1 ㅇ, 2 subad. $\hat{\delta}$ (AMNH [LP 4305]), 1 ๙ , 1 ㅇ, 3 juv. (LBRE), 1 के, 1 क, 2 juv. (MACN-Ar), 1 ㅇ, 2 juv. (MHNC), 1 ईे, 2 juv. (MZUC).

Additional Material: CHILE: Region IV (Coquimbo): Elqui Province: Mine El Indio, Cancha Sky base camp [29 $51^{\prime} 38^{\prime \prime} \mathrm{S}$ $70^{\circ} 02^{\prime} 12^{\prime \prime} \mathrm{W}, 3225$ m], v.1996, H. Vásquez C., pitfall trap, 1 q, 1 juv. (ULS); Mine El Indio, Mangueras, ca. $4000 \mathrm{~m}, 1$ juv. (AMNH), 1 juv. (LBRE); Mine El Indio, Pastos Largos [29 49'S 70 $03^{\prime} \mathrm{W}, 3600 \mathrm{~m}$ ], i.1995, H. Vásquez C., pitfall trap, 1 +, 1 juv. (ULS), 6.xi.2003, L. Prendini, C.I. Mattoni and J.A. Ochoa, UV detection, very cold and windy, full moon, alpine vegetation on scree slope near small stream, specimen sitting in open ground, 1 subad. (AMNH [LP 2402]); Mine El Indio, Quebrada El Negro [29 $47^{\prime} 06^{\prime \prime} \mathrm{S}$ $\left.70^{\circ} 00^{\prime} 00^{\prime \prime} \mathrm{W}, 3808 \mathrm{~m}\right]$, 6.xi.2003, C.I. Mattoni, L. Prendini, and J.A. Ochoa, UV detection and diurnal rock rolling, puna vegetation, low bushes and grass tufts, hard, rocky ground with bare patches, stones in places, at night, very cold and windy, full moon, specimens on rocky slope (juv. under stone), 1 क , 1 juv. (AMNH [LP 2401]); Mine El Indio, Tambo [ $29^{\circ} 48^{\prime} \mathrm{S} 69^{\circ} 58^{\prime} \mathrm{W}, 4030 \mathrm{~m}$ ], ii.1997, H. Vásquez C., pitfall trap, 1 s , 1 옹, 1 juv. (ULS); Paso del Agua Negra, between Juntas and international border, $30^{\circ} 12^{\prime} 11.5^{\prime \prime} \mathrm{S}$ $69^{\circ} 54^{\prime} 57.5^{\prime \prime} \mathrm{W}, 3350 \mathrm{~m}, 6.1 i i .2006$, A. Ojanguren Affilastro, L. Compagnucci, and $\mathrm{C}$. Cuezzo, UV detection, 1 s , 1 ㅇ, 1 subad. ㅇ, 1 juv. (MACN-Ar).

ETYMOLOGY: This species is named in honor of the Argentine arachnologist Martín J. Ramírez (MACN) for his contributions on the biodiversity and systematics of South American arachnids.

DiAGNOSIS: Orobothriurus ramirezi is closely related to $O$. alticola (fig. 5), based on similar pigmentation pattern, metasomal carination, and hemispermatophore morphology. The two species may be separated by the distal crest of the hemispermatophore, which is comparatively more developed, occupying almost the entire apex of the lamina, in $O$. ramirezi, than in $O$. alticola, in which it occupies only half the apex (figs. 36I, J, 47A, B). The telson vesicle of $O$. ramirezi is more rounded, especially in females (telson length/width ratio: $\delta, 2.65-$ 2.94 , mean $=2.78$; ㅇ, 2.13-2.37, mean $=$ 2.27; figs. $23 \mathrm{G}, 24 \mathrm{E}$ ) than that of $O$. alticola (telson length/width ratio: of, 2.87-3.21, mean $=3.07 ;$ o , 2.44-2.55, mean $=2.49$; fig. 23A). The dorsal surface of the femur and ventral surface of the metasoma are more pigmented, with broader stripes, in $O$. ramirezi than $O$. alticola. The metasomal carinae, especially the VL and VSM carinae of segments I and V, and the DL carinae of segment $\mathrm{V}$, are more developed in males of $O$. ramirezi than $O$. alticola (fig. 20A, C).

DESCRIPTION: Based on holotype of and paratypes. Measurements of holotype $\hat{\delta}$ and paratype $q$ recorded in table 3 .

Total length: of, 27.3-36.0 mm $(n=13$, mean $=31.6 \mathrm{~mm}$ ); ; , up to $37.8 \mathrm{~mm}$.

Color: General color yellowish with dark brown spots. Carapace, anterior margin unpigmented (fig. 44A, C); lateral margins with two spots laterally and two smaller spots posterolaterally, intermediate area with faint reticulate pigmentation; median ocular tubercle and lateral ocelli dark brown or black; posterior half of anteromedian longitudinal sulcus, median ocular tubercle, and posteromedian longitudinal sulcus pigmented. Chelicerae unpigmented. Pedipalp coxa unpigmented; trochanter, dorsal and lateral surfaces faintly pigmented; femur, ventral surface unpigmented, dorsal surface pigmented, except for oval unpigmented area, occupying up to twothirds of segment distally; internal and external surfaces unpigmented, except for faint stripes along VL and VI carinae; chela manus with six complete longitudinal stripes along carinae, joining at base of movable finger; fingers unpigmented except basally. Legs, coxa and trochanter unpigmented; femur, dorsal and prolateral surfaces sparsely spotted, spots becoming larger near articulation with patella; patella, prolateral, dorsal and ventral surfaces sparsely pigmented; basitarsi and telotarsi, dorsal and prolateral surfaces faintly spotted. Tergites I-VI each with two faint spots sublaterally, reaching pretergites on III-VI and delimiting unpig- 
mented median stripe; VII with two small, faint, spots of pigmentation submedially (fig. 44A, C). Sternum, genital opercula, pectines, and sternites III-VI unpigmented; sternite VII with two, often faint, spots sublaterally. Metasomal segment I, dorsal surfaces each with faint subtriangular spot medially; lateral surfaces pigmented between ML and LIM carinae; ventral surface with two narrow VL stripes becoming slightly broader in posterior half (fig. 44). Segments II-IV, dorsal surfaces each with small subtriangular spot medially; lateral surfaces densely pigmented below ML carinae; ventral surfaces each with three separate, narrow stripes (one VM and two VL), becoming broader in posterior half. Segment V, dorsal surface unpigmented; lateral surfaces with weak reticulate pigmentation; ventral surface with three separate stripes (one VM and two VL), becoming broader posteriorly. Telson vesicle, dorsal surface unpigmented $(q)$ or with faint longitudinal stripe (s); ventral surface with three broad dark stripes (two VL and one VM), separated by two narrow unpigmented stripes; aculeus sclerotized, dark reddish brown.

Chelicerae: Movable finger with two subdistal teeth.

Carapace: Median surfaces smooth; lateral margins finely granular, less so in 9 . Anterior margin linear, without median notch (fig. 16A, B). Anteromedian longitudinal sulcus obsolete; median ocular, posteromedian longitudinal and posterolateral sulci well developed. Median ocular tubercle raised, situated anteromedially; median ocelli two ocular diameters apart.

Pedipalps: Femur, DI and VI carinae complete, finely granular; DE carina obsolete, smooth (fig. 38A); internal surface finely and sparsely granular medially; other intercarinal surfaces smooth. Patella, DI and VI carinae obsolete, finely granular ( $\hat{\delta})$ or smooth ( + ) (fig. 38B-D); internal surface with two prominent granules distally, the larger adjacent to trichobothrium $i$; other intercarinal surfaces smooth.

Pedipalps: Femur, DI and VI carinae complete, granular (fig. 45A); DE carina complete, granular in distal third to distal half of segment, other carinae smooth; ventral surface sparsely granular, more densely granular in proximal half. Patella, DI and VI carinae complete, granular, less so in + (fig. 45B-D); DPP carina comprising small granules proximally; VPP carina absent; internal surface coarsely granular with prominent granule adjacent to trichobothrium $i$ near DI carinae; other surfaces smooth. Chela manus slender, fingers relatively elongated (fig. 46); length/width ratio: ô, 3.58-4.14 $(n=12$; mean $=3.84)$, ㅇ, 3.31$3.9(n=6$, mean $=3.62)$; length/height ratio: o, 2.94-3.75 $(n=12$; mean = 3.3), ㅇ, 3.06$3.4(n=6$, mean $=3.29)$; DMA, DI, and VM carinae obsolete, other carinae absent; intercarinal surfaces smooth; internal surface with acuminate apophysis ( $\delta$ ) or low bulge ( + ) near articulation of movable finger (fig. 46A, D); fingers, dentate margins each with median denticle row and 4-5 pairs of internal and external accessory denticles.

Trichobothria: Femur with 3 trichobothria, patella with 19, chela with 27 . Chela trichobothrium $E t_{3}$ situated proximal to Est (fig. 46).

Tergites: Tergites I-VI, surfaces finely granular (o) or smooth (q). Tergite VII tetracarinate, paired DL carinae restricted to posterior two-thirds of segment, paired DSM carinae to posterior half; intercarinal surfaces coarsely granular, other surfaces finely granular.

Legs: Femur and patella, prolateral surfaces finely granular, retroventral surfaces smooth. Femur, ventral carinae weakly developed; other carinae absent. Patella acarinate. Telotarsi, pro- and retroventral rows of spiniform macrosetae with following counts on leg I, 1/1; II, 2/2; III and IV, 3/3.

Pectines: Pectinal tooth count: $\delta, 21-26$ $(n=33$, median $=23)$; , , 15-20 $(n=34$, median $=18$ ).

Sternites: Sternites III-VI, surfaces smooth (क) or finely corrugated (\$), especially in posterior half; spiracles small, narrow. Sternite VII, surface smooth; VL and VSM carinae obsolete (fig. 18C).

Metasoma: Segment I, DL carinae complete, moderately granular; ML carinae complete, moderately granular in posterior two-thirds; one pair of ML macrosetae; LIM carinae complete, moderately granular in posterior half; VL and VSM carinae well developed (especially in $q$, fig. 19C), com- 
plete, granular; two pairs of VSM and VL macrosetae. Segment II, DL carinae complete, granular; ML carinae complete, granular; one pair of ML macrosetae; LIM carinae restricted to the posterior third; VSM and VL carinae well developed, complete ( + , fig. 18C) or obsolete ( $\hat{)})$; usually two pairs of VL and three pairs of VSM macrosetae. Segment III, DL and ML carinae complete, moderately granular; one pair of ML macrosetae; LIM carinae reduced to two or three granules in posterior quarter; VL and VSM carinae obsolete; two or three pairs of VL and three pairs of VSM macrosetae. Segment IV, DL carinae complete, granular; one pair of DL macrosetae; ML carina reduced to few distal granules ( $(+)$ or obsolete $(\hat{\delta})$; one or two pairs of ML macrosetae; LIM, VL and VSM carinae absent; three pairs of VL and three or four pairs of VSM macrosetae. Segment V, length/width ratio, of, 2.29-2.69 $(n=12$; mean $=2.44)$, ㅇ, 1.9-2.2 $(n=6$; mean $=2.02)$; DL carinae complete, more evident in anterior half; lateral margin smooth; ML carinae absent; four pairs of ML macrosetae; VL carinae complete ( $\delta$ ) or restricted to posterior three-quarters $(+)$; VL and VSM carinae situated close together, fused in posterior third; VM carina complete, obscured by surface granulation in posterior half (fig. 20C); four pairs of VL and VSM macrosetae; two pairs of macrosetae along posterior margin.

Telson: Length/width ratio: of, 2.65-2.94 $(n=13$, mean $=2.78)$; ㅇ, $2.13-2.37(n=10$, mean $=2.27)$. Length/height ratio: $\delta, 3.33-$ $3.89(n=13$, mean $=3.53)$; ㅇ, 2.63-3 $(n=$ 10 , mean $=2.86)$. Vesicle elongated $(\hat{\delta}$, fig. $23 \mathrm{G}, 24 \mathrm{G})$ or globose ( + , fig. $24 \mathrm{E}$ ); dorsal surface smooth, slightly concave, gland not apparent ( $\hat{\delta})$; ventral surface smooth ( $\hat{\delta})$ or granular ( $q$ ). Aculeus short and curved, more so in $q$.

Hemispermatophore: Apex very well developed; distal crest very well developed, occupying almost three quarters of apex, curved like ventral margin. Frontal crest weakly developed, less than half length of lamina; basal part oblique; distal part short, parallel to ventral margin of lamina, slightly undulated. Basal lobe, terminal process extending almost to constriction of frontal crest (fig. 47A, B).
DISTRIBUTION: Orobothriurus ramirezi is known only from localities above $3200 \mathrm{~m}$ in the Cordillera de Doña Ana of the Andes, in the Elqui Province of Region IV (Coquimbo), Chile (fig. 54).

ECOLOGY: Most specimens were collected near wetland ecosystems termed "vega" or "humedal" (Squeo et al., 1994; CepedaPizarro, 2004) in the high Andes. These habitats are characterized by an accumulation of water resulting in permanently flooded soil. The temperature at $3750 \mathrm{~m}$ varies from $-17{ }^{\circ} \mathrm{C}$ in winter, to more than $24{ }^{\circ} \mathrm{C}$ in summer, but temperatures below zero are possible throughout the year (Cepeda-Pizarro, 2004). Precipitation in the form of snow, which may accumulate up to $8 \mathrm{~m}$ in some areas, occurs mainly during winter. The vegetation corresponds to a steppe with diverse altitudinal levels: shrub steppe (or sub-Andean floor) at 2700-3500 m, subshrub steppe at $3500-4250 \mathrm{~m}$, and highAndean steppe at $4250-4450 \mathrm{~m}$, above which there is no vegetation (Squeo et al., 1994; Cepeda-Pizarro, 2004). Orobothriurus ramir$e z i$ has not been found in the upper altitudinal level, where the "vega" ecosystem is absent. It is sympatric with another bothriurid, Brachistosternus perettii Ojanguren Affilastro and Mattoni, 2006, that apparently prefers rocky areas (Ojanguren Affilastro and Mattoni, 2006). The most closely related species, $O$. alticola, inhabits similar habitats on the western side of the Andes. Despite the proximity of the nearest locality of $O$. alticola (only $16 \mathrm{~km}$ as the crow flies), the two species are allopatric, separated by the highest peaks of the Andes, the lowest pass being $4700 \mathrm{~m}$, where life is almost absent. Most adult males of $O$. ramirez $i$ were collected at night with UV light detection, sitting or walking near streams, probably in search of females, suggesting that the period when they where collected (late January, midsummer in the Southern Hemisphere) is the active season for this species.

Orobothriurus tamarugal, n. sp.

Figures 15D, 19F, 20E, 21H, 24F, 47C, D, $48-51,53$; table 3

Type Material: CHILE: Region I (Tarapacá): Iquique Province: Holotype $\hat{\sigma}$ 
(MACN-Ar), La Tirana, 2 km W, 20 19'59.8'S $69^{\circ} 40^{\prime} 07.6^{\prime \prime} \mathrm{W}, 999 \mathrm{~m}, 18 . i .2005$, A. Ojanguren Affilastro, C. Mattoni and J.A. Ochoa, UV sampling in Prosopis tamarugo forest. Paratypes: Pampa del Tamarugal National Park, Salar de Pintados (salt lake), near rangers' office and campsite, $20^{\circ} 26^{\prime} 16.1^{\prime \prime} \mathrm{S} \quad 69^{\circ} 45^{\prime} 55.2^{\prime \prime} \mathrm{W}$, 1014 m, 18.i.2005, A. Ojanguren Affilastro, C. Mattoni, and J.A. Ochoa, UV sampling in Prosopis tamarugo forest and under salt plates, 1 के (AMNH), 1 ㅇ (MZUC), 1 juv. (LBRE).

Additional Material: CHILE: Region I (Tarapacá): Iquique Province: Pampa del Tamarugal National Park, Salar de Pintados (salt lake), near rangers' office and campsite, $20^{\circ} 26^{\prime} 16.1^{\prime \prime} \mathrm{S} 69^{\circ} 45^{\prime} 55.2^{\prime \prime} \mathrm{W}, 1014 \mathrm{~m}, 18 . i .2005$, A. Ojanguren Affilastro, C. Mattoni, and J.A. Ochoa, UV sampling on Prosopis tamarugo forest and under salt plates, 1 +4 juv. (AMNH [LP 4308]).

ETYMOLOGY: The specific name is a noun in apposition referring to the Pampa del Tamarugal, where this species was collected.

Diagnosis: Orobothriurus tamarugal is most closely related to $O$. curvidigitus, $O$. paessleri, and $O$. quewerukana (fig. 5). The carapace possesses a median projection (epistome) at the anterior margin, and a marked anteromedian longitudinal sulcus (figs. 14C, $15 \mathrm{C}, \mathrm{D})$, and the males exhibit a curved movable finger on the pedipalp chela (fig. 51A) and a more elongated femur and patella than the females, in all four species. These species may be separated by the shape of the lamina of the hemispermatophore. The frontal crest is more developed and elongated, and the pedicel of the apex narrower in $O$. curvidigitus and $O$. quewerukana (figs. 28B, $40 \mathrm{E}$ ) than in $O$. paessleri and $O$. tamarugal (figs. 28C, D, 47D). Most specimens of $O$. quewerukana possess one or two small folds in the distal crest (fig. 40E), which are absent in $O$. curvidigitus, $O$. paessleri, and $O$. tamarugal (figs. 28A, B, 47D). Additionally, the ventral border of the distal portion of the apex is straight in $O$. tamarugal, but slightly curved in $O$. quewerukana. The metasomal carinae of $O$. curvidigitus, $O$. quewerukana, and $O$. tamarugal are similarly developed: the DL and ML carinae are complete and granular on segments I-IV, the VL carinae obsolete and smooth on I-IV, and the VSM carinae almost completely fused with the VL carinae on V. Orobothriurus tamarugal can be separated from $O$. curvidigitus, $O$. paessleri, and $O$. quewerukana by the near complete absence of pigmentation, which is present on the carapace, tergites, and ventral surfaces of the metasoma in the other species. The carinae of the pedipalp femur are less developed in $O$. tamarugal: the DE carinae, in particular, are incomplete in $O$. tamarugal (fig. 49A), but complete and comprising larger granules in $O$. curvidigitus and $O$. quewerukana (fig. 42A). The IM carina of the male pedipalp chela is present and finely granular in $O$. tamarugal, but absent in $O$. curvidigitus and $O$. quewerukana. The ventral surfaces of sternite VII and metasomal segment I are densely granular in $O$. tamarugal (fig. 19F), finely granular to smooth in O. quewerukana (fig. 19C), and entirely smooth in O. curvidigitus (fig. 19A).

DESCRIPTION: Based on holotype $\hat{\delta}$ and paratypes. Measurements of holotype $\hat{\delta}$ and paratype $q$ recorded in table 3 .

Total length: $\delta$, 23.5-35.3 mm $(n=2)$; 우, $30.1 \mathrm{~mm}(n=1)$.

Color: General color yellowish, with faint dark brown spots. Carapace almost unpigmented (adults), except for median ocular tubercle and lateral ocelli (fig. 48) or faintly pigmented (juveniles), one spot near anterior margin, two spots median laterally and two faint spots posterolaterally, with median ocular tubercle, lateral ocelli, anteriomedian and posteriomedian longitudinal sulci more densely pigmented. Tergites almost unpigmented, except for two large faint spots laterally, delimiting broad, unpigmented median band (fig. 48). Chelicerae, pedipalps, legs, sternum, genital operculum, pectines, sternites, metasoma, and telson unpigmented; aculeus sclerotized, dark reddish brown.

Chelicerae: Movable finger with two subdistal teeth, very small in $\delta$.

Carapace: Anterior margin granular ( $\vec{\delta})$ or smooth ( + ); anteromedian surfaces smooth; lateral margins finely granular, more so in $\hat{\delta}$. Anterior margin linear ( $q$, juv.) or with small median projection (epistome) ( $\delta$, fig. 15D). Anteromedian longitudinal, median ocular, and posteromedian sulci well developed; posterolateral sulci obsolete. Median ocular tubercle raised, situated 
anteromedially; median ocelli two ocular diameters apart.

Pedipalps: Femur, more elongated in $\delta$, length/width ratio: $\hat{\delta}, 4.05-4.27(n=2)$, 우 3.13; DI and VI carinae complete, granular; DE carina almost complete, coarsely granular in proximal three-quarters, smooth elsewhere; internal surface sparsely and coarsely granular (fig. 49A). Patella, more elongated in $\hat{\delta}$, length/width ratio: $\hat{\delta}, 3.45-4.10(n=$ 2),,+ 2.95 ; DI and VI carinae almost complete, granular (fig. 49B-D); DE and VE carinae vestigial, finely and sparsely granular in $\hat{\delta}$; internal surface sparsely granular, with prominent granule adjacent to trichobothrium $i$ near DI carina. Chela manus slightly rounded, fingers relatively elongated (figs. 49, 50); length/width ratio: $\hat{\delta}, 3.18-4.07(n=2)$, o, 3.83; length/height ratio: $\delta$, 2.90-3.62 $(n=$ 2), + , 3.83; carinae obsolete, finely granular (less so in 9 ) or absent; VM carina restricted to proximal three-quarters of manus; DS, DMA, DI carinae complete, finely and densely granular ( $\hat{\sigma}$ ) or smooth ( + ); D carina finely and sparsely granular; IM carina finely and sparsely granular in proximal half (fig. 51B); intercarinal surfaces finely granular ( $\hat{\delta}$, fig. 51) or smooth ( + , fig. 50); internal surface with acuminate apophysis ( $\hat{\delta}$ ) or low bulge ( + ) near articulation of movable finger (क) (figs. 50A, 51B); movable finger ( $\delta$ ), strongly curved, creating small gap with fixed finger when fingers closed (fig. 51A); fingers, dentate margins each with median denticle row and 5-6 pairs of internal and external accessory denticles.

Trichobothria: Femur with 3 trichobothria, patella with 19, chela with 27 (figs. 49-51). Chela trichobothrium $E t_{3}$ situated in same axis as, or slightly basal to Est (figs. 50, 51).

Tergites: Tergites I-VI, surfaces finely granular, more coarsely and densely so near distal margins of III-VI ( $\delta$ ) or smooth ( + ). Tergite VII tetracarinate, paired DL carinae restricted to posterior two-thirds of segment, paired DSM carinae to posterior third; intercarinal surfaces granular.

Legs: Femur and patella, prolateral surfaces finely granular, retrolateral surfaces smooth. Femur, ventral carinae weakly developed; other carinae absent. Patella acarinate. Telotarsi, pro- and retroventral rows of spiniform macrosetae with following counts on leg I, 1/1; II, 2/2; III and IV, 3/3.

Pectines: Pectinal tooth count: $\delta, 19-21$ $(n=6$; mode $=20)$; ㅇ, $17-18(n=2)$.

Sternites: Sternites III-VI, surfaces smooth; spiracles small, elliptical, and narrow. Sternite VII, surface smooth in anterior half, sparsely granular in posterior half; VL carinae obsolete, slightly more developed in holotype $\delta$ (fig. 19F); VSM carinae absent.

Metasoma: Segment I, DL carinae complete, moderately to coarsely granular; ML carinae well developed, becoming more coarsely granular in posterior two-thirds; LIM carinae moderately to coarsely granular, restricted to posterior two-thirds, oriented obliquely to antero-dorsal surface, almost joining ML carinae; one pair of macrosetae situated medially between ML and LIM carinae; VL carinae complete, obsolete, finely granular; VSM carinae weakly developed, sparsely granular; two pairs of VSM and VL macrosetae (fig. 19F). Segments II-IV, DL carinae complete, coarsely granular; one pair of DL macrosetae; ML carinae complete, coarsely granular; one pair of ML macrosetae; surfaces between ML and LIM carinae granular on segments II and III; LIM carinae reduced to few granules in posterior third of segment II, less developed on III, absent on IV; VL carinae vestigial, becoming absent toward segment IV; VSM absent or reduced to few scattered granules on segment II ( $q$ ); three pairs of VL and VSM macrosetae. Segment V, length/width ratio, ô, 1.95-2.24, ㅇ, 1.86; DL carinae reduced to few granules in anterior half; one pair of DL macrosetae; ML carinae obsolete, granular; two pairs of ML macrosetae; lateral intercarinal surfaces finely and sparsely granular; VL and VM carinae complete, granular; VL and VSM carinae fused, only separated medially (fig. 20E); ventral intercarinal surfaces granular; three pairs of VL and VSM macrosetae; two pairs of macrosetae along posterior margin.

Telson: Length/height ratio: $\hat{\delta}, 2.53-3.06$ $(n=2)$;,$+ 2.3(n=1)$. Vesicle elongated ( $\hat{\delta}$, fig. $22 \mathrm{H}$ ) or oval (의 fig. 24F); dorsal surface smooth, slightly concave medially, gland not apparent ( $\hat{\delta}$ ); ventral surface coarsely granular. Aculeus short and curved, more so in + . 


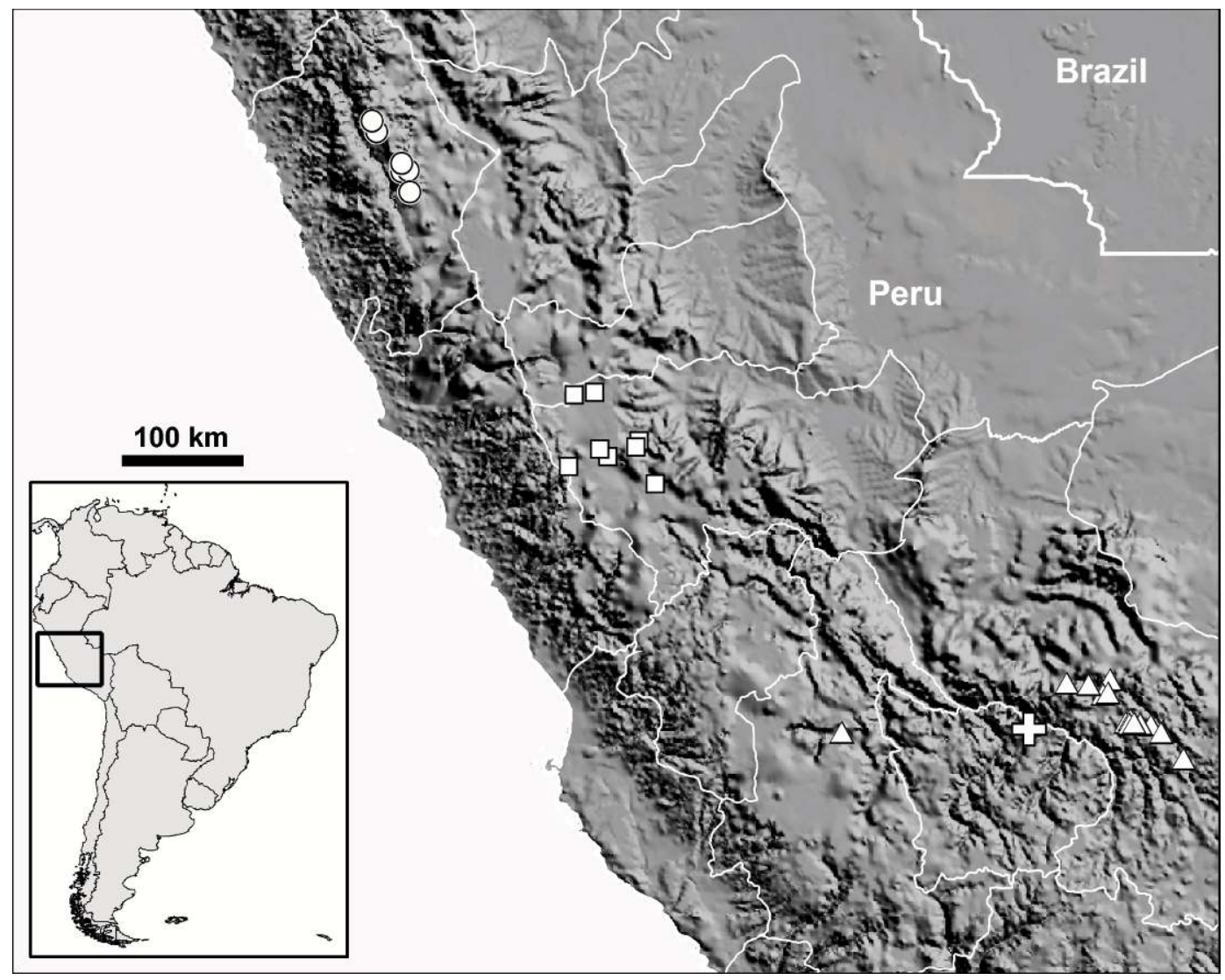

Fig. 52. Orobothriurus Maury, 1976, locality records in central Peru. Orobothriurus ampay Ochoa and Acosta, 2003, cross; Orobothriurus huascaran, n. sp., circles; Orobothriurus parvus Maury, 1976, squares; Orobothriurus wawita Acosta and Ochoa, 2000, triangles.

Hemispermatophore: Apex very well developed; distal crest almost straight, well developed, restricted to distal half of apex. Frontal crest weakly developed, less than half length of lamina; basal part oblique; distal part short, parallel to ventral margin of lamina, lateral projections slightly undulated with minute granulation. Basal lobe, terminal process extending almost to median part of frontal crest (fig. 47C, D).

DisTRIBUTION: All known records of this species are located in the Pampa del Tamarugal of Iquique Province, Region I (Tarapacá), Chile (figs. 3A, 53).

ECOlOGY: The Pampa del Tamarugal is a desert area characterized by the near absence of rainfall $(0.2-1 \mathrm{~mm}$ per year), high-salinity soils (mostly of alluvial origin from the Andes), depressions with salt lakes, and a forest dominated by Prosopis tamarugo and Prosopis chilensis (Mol.) Stuntz trees (fig. 3A). Prosopis tamarugo is a deciduous open-crowned tree up to $18 \mathrm{~m}$ tall, with a trunk up to $80 \mathrm{~cm}$ in diameter, a dense mat of lateral roots and a deep taproot (up to $6 \mathrm{~m}$ deep on trees $15 \mathrm{~m}$ tall; Habit et al., 1981; Serra, 1997). Temperatures in the Pampa del Tamarugal vary from $-12{ }^{\circ} \mathrm{C}$ during winter nights to $36{ }^{\circ} \mathrm{C}$ on summer days, with a daily range of more than $35^{\circ} \mathrm{C}$ in summer. The salt lakes are dry, surface water is absent year-round, and the groundwater may be more than $60 \mathrm{~m}$ below the surface. The only humidity is provided by sporadic fog. Prosopis tamarugo forests occur only where groundwater is between $2-40 \mathrm{~m}$ below the surface (Serra, 1997). Specimens of O. tamarugal were collected at night, with UV light detection, inside the forest. The two 


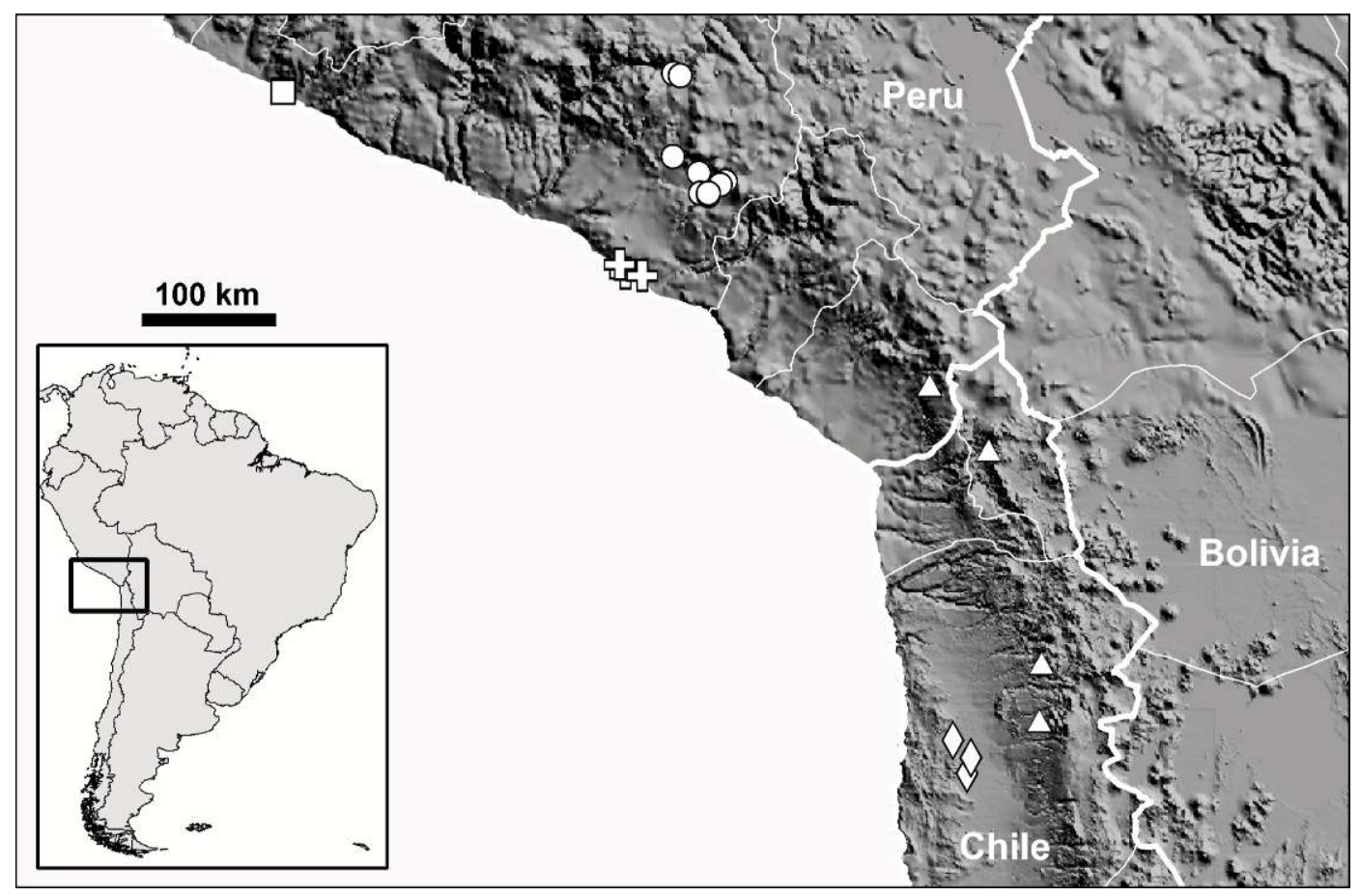

Fig. 53. Orobothriurus Maury, 1976, locality records in southern Peru and northern Chile. Orobothriurus atiquipa Ochoa and Acosta, 2002, square; Orobothriurus curvidigitus (Kraepelin, 1911), circles; Orobothriurus paessleri (Kraepelin, 1911), crosses; Orobothriurus quewerukana, n. sp., triangles; Orobothriurus tamarugal, n. sp., diamonds.

males collected were active on the surface, sitting below large trees. The females and juveniles were inactive, resting under large plates of hard soil and salt (one of the forests is located near a dry salt lake). Brachistosternus donosoi Cekalovic, 1974, a larger and more active bothriurid species, was collected in sympatry.

\section{Orobothriurus wawita}

Acosta and Ochoa, 2000

Figures 13C, D, 16C, D, 19E, 21C, 22F, $25 \mathrm{~B}, \mathrm{C}, 27 \mathrm{C}, 52$

Orobothriurus wawita Acosta and Ochoa, 2000: 137-143, figs. 1-13; 2001: 205; 2002: 18; Ochoa, 2004a: 43, 52, 55, 73, figs. 1, 2, 21, table 1; 2005: 55, 56, figs. 7, 9, table 2; Rein, 2007: 5.

Type Material: PerU: Cusco Department: Urubamba Province: Holotype of (MACN-Ar 9652), Pacchac, Pumahuanca, $13^{\circ} 13^{\prime} \mathrm{S} 72^{\circ} 06^{\prime} \mathrm{W}, 3800 \mathrm{~m}$, 17.vii.1998, J.A. Ochoa. Paratypes: Cusco Department: Urubamba Province: same data as holotype, 1 oे,
1 (CDA 019); same locality as holotype, 23.vii.1998, J. Flores and J.A. Ochoa, 2 sิ, 2 q (MHNC), 1 i (MACN-Ar 9653); Maras [13 ${ }^{\circ} 19^{\prime} 53^{\prime \prime} \mathrm{S} 72^{\circ} 09^{\prime} 22^{\prime \prime} \mathrm{W}, 3360 \mathrm{~m}$ ], 29.x.1997, O. Mujica and J.A. Ochoa, 1 of (MHNC). Ayacucho Department: Cangallo Province: Común Pampa [133' ${ }^{\circ} \mathrm{S} 74^{\circ} 08^{\prime} \mathrm{W}, 2700 \mathrm{~m}$ ], 10.ii.1963, R. Garcia, 2 ㅇ (MUSM).

New ReCords: PERU: Cusco Department: Quispicanchis Province: Lucre, Huacarpay $\left[13^{\circ} 36^{\prime} 30^{\prime \prime} \mathrm{S} 71^{\circ} 44^{\prime} 03^{\prime \prime} \mathrm{W}\right]$, ca. $3000 \mathrm{~m}$, 14.i.2004, J.A. Ochoa, 2 juv. (AMNH [LP 3059]). Urubamba Province: Ollantaytambo [13 $\left.{ }^{\circ} 15^{\prime} 18^{\prime \prime} \mathrm{S} 72^{\circ} 15^{\prime} 46^{\prime \prime} \mathrm{W}, 2861 \mathrm{~m}\right]$, 14.iii.1947, J.C. Palhsler, 1 i (MACN-Ar), 13.ii.1983, S. and A. Roig, 1 ㅇ (MACN-Ar); Ollantaytambo, Río Kusichaca (Inka trail) $\left[13^{\circ} 14^{\prime} 45^{\prime \prime} \mathrm{S}\right.$ $72^{\circ} 25^{\prime} 46^{\prime \prime} \mathrm{W}$ ], $2750 \mathrm{~m}, 15 . \mathrm{i} .1983$, S. and A. Roig, 1 \& (MACN-Ar).

DIAGNOSIS: Orobothriurus wawita may be distinguished from other species of the genus by the following characters. This species lacks an apophysis on the internal surface of the pedipalp chela manus of the male 


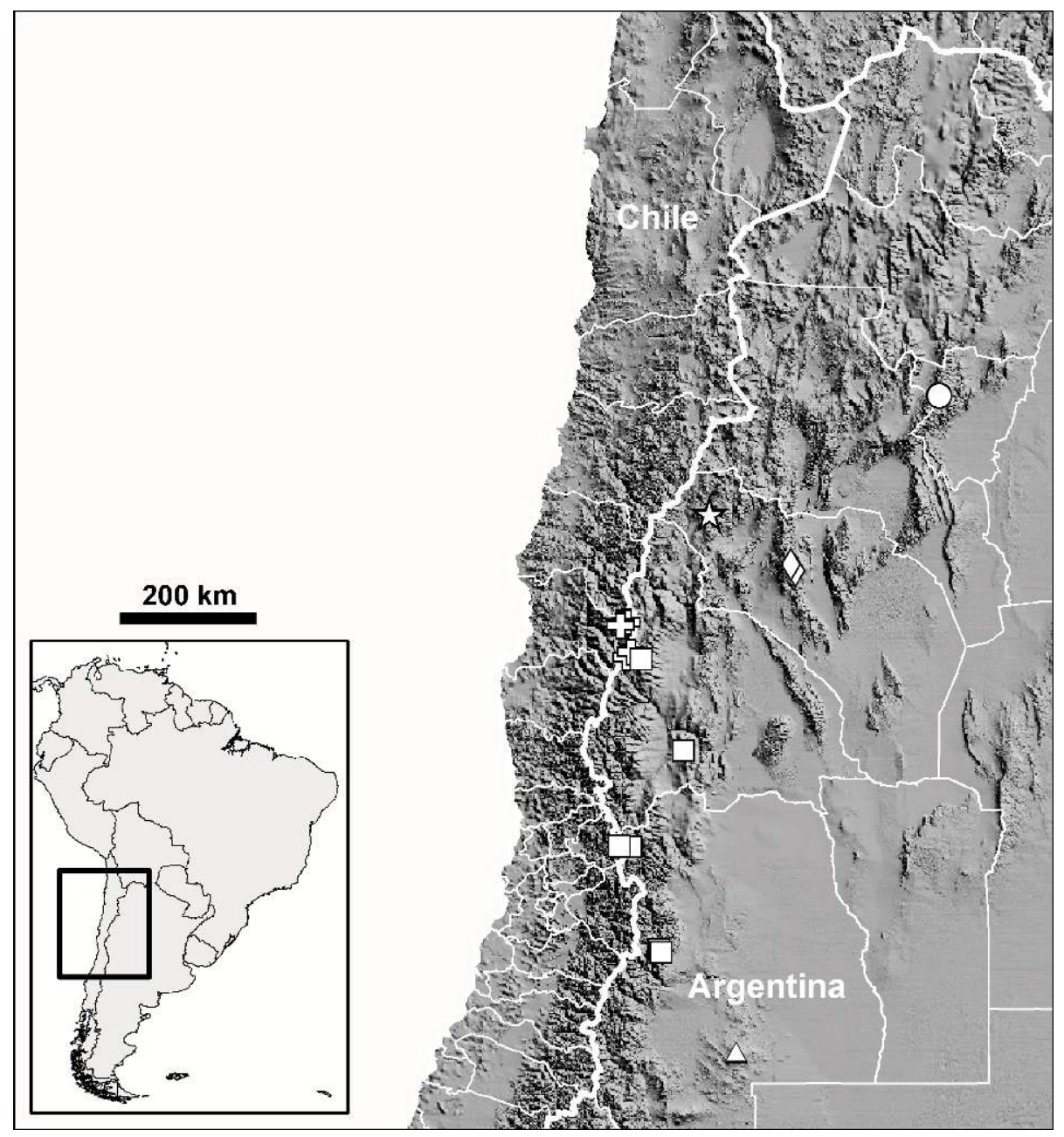

Fig. 54. Orobothriurus Maury, 1976, locality records in Argentina and central-northern Chile. Orobothriurus alticola (Pocock, 1899), squares; Orobothriurus calchaqui, n. sp., circle; Orobothriurus compagnuccii, n. sp., star; Orobothriurus famatina Acosta, 2001, diamonds; Orobothriurus grismadoi Ojanguren Affilastro et al., 2009, triangle; Orobothriurus ramirezi, n. sp., crosses.

(fig. 25C), which is present in all other species except $O$. ampay, in which it is reduced to vestigial granules. The pedipalp chela manus of $O$. wawita is slender (fig. 23B, C) with a greater length/width ratio, 5.6-6.5 (क), 4.465.45 ( 9 ), than all other species, 2.98-4.6 (o), 3.2-4.22 ( 9 ). The pigmentation on the ventral surfaces of the metasoma of $O$. wawita comprises irregular scattered spots, not forming a VM stripe (fig. 13D) that is present and well defined, at least on metasomal segments II-IV, in other species (figs. 11, 13A). Orobothriurus wawita is most closely related to $O$. parvus (fig. 5). Both species share similar reticulate pigmentation along the metasomal DL carinae (figs. 12B, 13C), macrosetal counts on the ventral surfaces of the metasoma, and hemispermatophore morphology, including an elongated lamina apex and a short frontal crest (figs. 27B, C). These two species may be distinguished by the following characters. The fixed finger of the pedipalp chela of the male is straight, such that no gap is evident when the fingers are closed, in O. wawita (fig. 25B, C), whereas it is slightly curved, creating a small gap when the fingers are closed, in $O$. parvus (fig. 26A). The VL and VM carinae of metasomal 
segment $\mathrm{V}$ are absent ( $\delta$ ) or restricted to the distal third of the segment ( $q$ ) in O. wawita (figs. 21C, 22F), but complete in O. parvus (fig. 22E). The ventral margin of the apex of the hemispermatophore is straight in $O$. wawita (fig. 27C), but curved distally to the dorsal surface in O. parvus (fig. 27B).

DisTRIBUTION: All except one record of this species are situated in inter-Andean valleys at $2700-3800 \mathrm{~m}$ in the Ayacucho and Cusco departments of southern Peru (figs. 2B, C, 52). A record from Potosi $\left(19^{\circ} 34^{\prime} \mathrm{S} 65^{\circ} 28^{\prime} \mathrm{W}\right), 900 \mathrm{~km}$ from Cusco in Bolivia (fig. 1), is based on a single female, which, although morphologically similar to Peruvian material, possesses slight differences in pigmentation pattern and granulation of the metasomal segments (Acosta and Ochoa, 2002). This record is probably a mislabeling.

ECOLOGY: This species is endemic to the Queswa biogeographical region (Marín Moreno, 1961; Ceballos Bendezú, 1976; Ochoa, 2005; fig. 2B, C) and syntopic with two other bothriurids, Brachistosternus andinus and Pachakutej oscari Ochoa, 2004.

\section{ACKNOWLEDGMENTS}

We are grateful to Iván Benoit (Corporación Nacional Forestal del Gobierno de Chile, CONAF) for assistance with obtaining permits to collect scorpions in Chilean National Parks, to the CONAF staff at Pampa del Tamarugal National Park, and to the Dirección General Forestal y de Fauna Silvestre, Ministerio de Agricultura de Peru (ex-NRENA) for permits 061-2004-INRENA-IFFS-DCB，002-2008INRENA-IFFS-DCB, to collect scorpions in Peru. We thank John Achicahuala, Juan Carlos Chaparro, Luis Compagnucci, Roberto Gutiérrez, Paula Korob, Juan José Martinez, Daniel Muñiz, Williams Paredes, Luis Piacentini, Jaime Pizarro, Elias Ponce, Aarón Quiroz, J.L. Velasquez, Matías Vivanco, Ulrich Zanabria, and Horacio Zeballos for assisting us in the field; the following curators and collections managers for loaning and/or granting access to material from the collections in their care: Petra Sierwald and Alfred Newton (FMNH), František Kovařík (FKPC), Olintho Aguilar (MHNC), Gerardo Lamas and Diana Silva (MUSM), Alberto Chiarle (MRSN), and Hieronymus Dastych (ZMH);
Luis Acosta for access to material on loan from MHNG; Wilfredo Mendoza (MUSM) for providing data on Peruvian vegetation; Ricardo Pinto da Rocha, Joyce Vitorino Villegas, Oscar Mujica, Horacio Larrain Barros, and Hugo Zamora for providing some of the photos of habitats and live habitus; Steve Thurston for assistance with preparing the plates; and two anonymous reviewers for comments on the manuscript. This research was supported by a Kalbfleisch Postdoctoral Research Fellowship from the AMNH, and a fellowship from the Fundação de Amparo à Pesquisa do Estado de São Paulo, Brazil (FAPESP 2010/00018-9) to J.A.O., grants from the Consejo Nacional de Investigaciones Científicas y Técnicas, Argentina (CONICET) to A.A.O.A. and C.I.M., and a Genomics Postdoctoral Research Fellowship from the AMNH to C.I.M. Fieldwork in Chile was financially supported by the following sources: J.A.O., C.I.M. and L.P. (2003) from U.S. National Science Foundation grant EAR 0228699 to L.P.; J.A.O, C.I.M. and A.A.O.A. (2005) from the AMNH; A.A.O.A. (2006) from CONICET grant PIP 6502. Fieldwork in Peru (2008) was funded in part by a Kalbfleisch Postdoctoral Research Fellowship from the AMNH to J.A.O. Fieldwork in Argentina (2006, 2007) was financially supported by a CONICET grant PIP 6502 to A.A.O.A.

\section{REFERENCES}

Abalos, J.W. 1959. Scorpionida. Primeras Jornadas Entomoepidemiológicas Argentinas 2: 591-593.

Abalos, J.W. 1963. Scorpions of Argentina. In H.L. Keegan and W.V. MacFarlane (editors), Venomous and poisonous animals and noxious plants of the Pacific region: 111-117. New York: MacMillan.

Acosta, L.E. 1997. Descripcion de Bothriurus olaen, nueva especie de escorpión de Argentina central (Scorpiones: Bothriuridae). Revue Arachnologique 12 (1): 1-8.

Acosta, L.E. 2002. Case 3213. Bothriurus alticola Pocock, 1899. (Arachnida, Scorpiones): proposed precedence of the specific name over the subspecific name of Cercophonius brachycentrus bivittatus Thorell 1877. Bulletin of Zoological Nomenclature 59 (3): 176-179.

Acosta, L.E. 2005. Rediscovery of Orobothriurus bivittatus (Thorell 1877) stat. n., comb. n. in the Sierra del Tontal, Argentina (Scorpiones, Bothriuridae). Zootaxa 916: 1-15. 
Acosta, L.E. 2006. Case 3332. Cercophonius brachycentrus bivittatus Thorell, 1877 (currently Orobothriurus bivittatus; Arachnida, Scorpiones): replacement of the holotype by the designation of a neotype. Bulletin of Zoological Nomenclature 63 (1): 20-22.

Acosta, L.E., and E.A. Maury. 1998. Scorpiones. In J.J. Morrone and S. Coscaron (editors), Biodiversidad de arthropodos argentinos. Una perspectiva biotaxonómica: 545-559. La Plata, Argentina: Ediciones Sur.

Acosta, L.E., and J.A. Ochoa. 2000. Nueva especie de Orobothriurus, Maury, del Perú. (Scorpiones, Bothriuridae). Revue Arachnologique 13 (10): 135-144.

Acosta, L.E., and J.A. Ochoa. 2001. Two new species of Orobothriurus Maury 1976, from Argentina and Peru, with comments on the systematics of the genus (Scorpiones, Bothriuridae). In V. Fet and P.A. Selden (editors), Scorpions 2001. In memoriam Gary A. Polis: 203-214. Burnham Beeches, Bucks: British Arachnological Society.

Acosta, L.E., and J.A. Ochoa. 2002. Lista de los escorpiones bolivia nos (Chelicerata: Scorpiones), con notas sobre su distribución. Revista de la Sociedad Argentina de Entomología 61 (3-4): 15-23.

Aguilar, P.G., and O. Meneses. 1970. Escorpiones y escorpionismo en el Perú I: Nota preliminar sobre los Scorpionida peruanos. Anales Científicos de la Universidad Nacional Agraria La Molina 8: 1-5.

Brack, A. 1986. Ecología de un país complejo. In Gran geografía del Perú. Naturaleza y Hombre 2, 175-319. Barcelona: Manfer-Juan Mejía Baca.

Bücherl, W. 1953. Quilópodos, aranhas e escorpiões enviados ao Instituto Butantan para determinaçao. Memórias do Instituto de $\mathrm{Bu}-$ tantan 25 (1): 109-152.

Bücherl, W. 1959a. Escorpiones e escorpionismo no Brasil. VIII. Revisão das espécies do gênero Bothriurus descritas da Argentina. Memórias do Instituto Butantan 1957-58 28: 19-43.

Bücherl, W. 1959b. Escorpiones e escorpionismo no Brasil. X. Cátalogo dacoleção escorpiônica do Instituto Butantan. Memórias do Instituto Butantan 29: 255-275.

Bücherl, W. 1969. Giftige Arthropoden. In E.J. Fittkau, et al. (editors). Biogeography and ecology in South America (Monographiae Biologicae 19) 2: 764-793. Dordrecht: W. Junk.

Bücherl, W., et al. 1963. Escorpiões e escorpionismo no Brasil. XII. Revisão sistemática e crítica dos escorpiões do gênero Bothriurus Peters, 1861. Memórias do Instituto de Butan$\tan$ 30: 207-226.
Byers, A.C. 2000. Contemporary landscape change in the Huascaran National Park and buffer zone, Cordillera Blanca, Peru. Mountain Research and Development 20 (1): 52-63.

Cabrera, A.L., and A.W. Willink. 1980. Biogeografía de América Latina. Serie de Biología, OEA Monographs vol. 13, 122 pp.

Caminos, R. 1999. Geología argentina. Buenos Aires: SEGEMAR, 796 pp.

Ceballos Bendezú, I. 1976. Nuevo esquema biogeográfico del Perú. Revista Universitaria, Universidad Nacional del Cusco 130: 19-44.

Cei, J.M. 1982. Aspetti geo-biogeografici inediti della Sierra di Famatina, il più elevato massiccio d'America del Sud dopo le cordigliere andine (Argentina centro-occidentale). L'Universo (Instituto Geografico Militare, Firenze) 62 (4): 643-672.

Cepeda-Pizarro, J. 2004. Ecología del paisaje de la Alta montaña del Valle de Elqui. La Serena: Ediciones Universidad de La Serena, 132 pp.

Cekalovic K., T. 1966. Contribución al conocimiento de los escorpiones chilenos. Museo Nacional de Historia Natural, Noticiario Mensual (Santiago) 10 (118): 1-8.

Cekalovic K., T. 1974. Bothriurus dumayi n. sp. de escorpión chileno (Scorpiones, Bothriuridae). Boletín de la Sociedad Biológica de Concepción 48: 209-216.

Coddington, J.A., and R.K. Colwell. 2001. Arachnids. In S.A. Levin (editor), Encyclopedia of biodiversity. Vol. 1, 199-218. San Diego, CA: Academic Press.

Dávila Flores, J. 1982. Escorpiones de las Lomas de Matarani - Islay. Actas 8vo Congreso Latinoamericano de Zoología, Merida, Venezuela:, 547-551.

Dupré, G. 2007. Conspectus Genericus Scorpionorum 1758-2006. Euscorpius 50: 1-31. (http://www. science.marshall.edu/fet/euscorpius/pubs.htm).

Fet, V., and M.E. Soleglad. 2005. Contributions to scorpion systematics. I. On recent changes in high-level taxonomy. Euscorpius 31: 1-13.

Flórez D., E. 2001. Escorpiones de la Familia Buthidae (Chelicerata: Scorpiones) de Colombia. Biota Colombiana 2 (1): 25-30.

Francke, O.F. 1974. Description of the male of Bothriurus (Andibothriurus) peruvianus MelloLeitão (Scorpionida: Bothriuridae). Journal of Arachnology 1: 215-220.

Francke, O.F. 1977. Escorpiones y escorpionismo en el Peru VI: Lista de especies y claves para identificar las familias y los géneros. Revista Peruana de Entomología 20: 73-76.

Francke, O.F. 1985. Conspectus Genericus Scorpionorum 1758-1982 (Arachnida: Scorpiones). Occasional Papers of the Museum, Texas Tech University 98: 1-32. 
Francke, O.F., and M.E. Soleglad. 1980. Two new Hadruroides Pocock from Peru (Scorpiones, Vaejovidae). Occasional Papers of the Museum, Texas Tech University 69: 1-13.

Gajardo, R. 1993. La vegetación natural de Chile, clasificación y distribución geográfica. Santiago de Chile: Editorial Universitaria, 165 pp.

Galiano, M.E., and E.A. Maury. 1979. Lista de los ejemplares típicos de Arachnida (Araneae, Opiliones, Scorpiones y Solifugae) depositados en el Museo Argentino de Ciencias Naturales "Bernardino Rivadavia." Revista del Museo Argentino de Ciencias Naturales "Bernardino Rivadavia” Entomología 5 (11): 301-334.

Habit, M.A., D.T. Contreras, and R.H. González. 1981. Prosopis tamarugo: fodder tree for arid zones. FAO Plant Protection Paper 25. Rome: FAO.

Herrera, F.L. 1930. La vegetación de la costa peruana. Revista Universitaria, Universidad Nacional del Cusco 59 (1): 71-79.

International Commission on Zoological Nomenclature. 2008. Opinion 2191 (Case 3332). Cercophonius brachycentrus bivittatus Thorell, 1877 (currently Orobothriurus bivittatus; Arachnida, Scorpiones): proposed replacement of the holotype by the designation of a neotype not accepted. Bulletin of Zoological Nomenclature 65 (1): 69-70.

Kamenz, C., and L. Prendini. 2008. An atlas of book lung fine structure in the order Scorpiones (Arachnida). Bulletin of the American Museum of Natural History 316: 1-359.

Kovař́k, F. 1998. Štiři (Scorpions). Jihlava: Madagaskar, 175 pp. [in Czech].

Kraepelin, K. 1911. Neue Beiträge zur Systematik der Gliederspinnen. Mitteilungen aus dem Naturhistorischen Museum (2. Beiheft zum Jahrbuch der Hamburgischen Wissenschafttlichen Anstalten, 1910) 28 (2): 59-107.

Lampe, E. 1917. Katalog der Skorpione, Pedipalpen und Solifugen des Naturhistorischen Museums der Residenzstadt Wiesbaden. Jahrbücher des Nassauischen Verein für Naturkunde 70 (1): 185-203.

Lomolino, M.V. 2001. Elevation gradients of species-density: historical and prospective views. Global Ecology and Biogeography 10: 3-13.

Lourenço, W.R. 1995. Les scorpions (Chelicerata, Scorpiones) de l'Équateur avec quelques considérations sur la biogéographie et la diversité des espèces. Revue Suisse de Zoologie 102 (1): 61-88.

Lourenço, W.R. 1997. Additions à la faune de scorpions neotropicaux. Revue Suisse de Zoologie 104 (3): 587-604.

Lourenço, W.R. 2002. Scorpiones. In J. Adis (editor), Amazonian Arachnida and Myriapoda: 399-438. Sofia-Moscow: Pensoft Publishers.

Lourenço, W.R. 2003. Scorpion biogeography: a review. In J.J. Morrone and J. Llorente Bousquets (editors), Una perspectiva latinoameri- cana de la biogeografía: 227-240. México, D.F.: Las Prensas de Ciencias, Facultad de Ciencias, UNAM.

Lourenço, W.R. 2005. Confirmation de la presence de la famille des Buthidae C.L. Koch, 1837 au Chili (Chelicerata, Scorpiones). Boletín de la Sociedad Entomológica Aragonesa 37: 109-112.

Lourenço, W.R., and H. Dastych. 2001. A contribution to the scorpion fauna of Peru, with a description of Chactas koepckei sp. nov. (Arachnida: Scorpiones). Mitteilungen aus dem Hamburgischen Zoologischen Museum und Institut 98: 51-62.

Lourenço, W.R., and E.A. Maury. 1985. Contribution à la connaissance systemátique des scorpions appartenant au "complexe" Tityus bolivianus Kraepelin, 1895 (Scorpiones, Buthidae). Revue Arachnologique 6 (3): 107-126.

Lourenço, W.R., and J. Qi. 2006. Mountain scorpions: a new genus and species from Tibet (China). Comptes Rendus Biologies 329: 289-295.

Lowe, G., V. Fet, 2000. Family Bothriuridae Simon 1880. In, V. Fet, W.D. Sissom, G. Lowe, and M.E. Braunwalder, Catalog of the scorpions of the world (1758-1998):17-53. New York: New York Entomological Society.

Marín Moreno, F. 1961. Panorama fitogeográfico del Perú. Revista Universitaria, Universidad Nacional del Cusco 120: 9-68.

Masnú de Moreno, S.J. 1991. Aportes al estudio de la escorpiofauna mendocina. Revista del Museo de Historia Natural de San Rafael 11 (4): 169-200.

Mattoni, C.I., and L.E. Acosta. 2005. A new species of Bothriurus from Brazil (Scorpiones, Bothriuridae). Journal of Arachnology 33 (3): 735-744.

Mattoni, C.I., and L.E. Acosta. 2006. Systematics and distribution of three Bothriurus species (Scorpiones, Bothriuridae) from central and northern Chile. Studies on Neotropical Fauna and Environment 41 (3): 235-250.

Mattoni, C.I., J.A. Ochoa, A.A. OjangurenAffilastro, and L. Prendini. (in litt.) Reanalysis of the phylogeny of the Andean scorpion genus Orobothriurus (Scorpiones: Bothriuridae) phylogeny, Andean biogeography, and the relative importance of genitalic and somatic characters. Zoologica Scripta.

Maury, E.A. 1973. Sobre las especies de Bothriurus descriptas por F. Werner (Scorpiones: Bothriuridae). Neotropica 19 (59): 110-112.

Maury, E.A. 1975. Escorpiones y escorpionismo en el Perú IV: Revisión del género Hadruroides Pocock, 1893 (Scorpiones, Vaejovidae). Revista Peruana de Entomología 17 (1): 9-21. 
Maury, E.A. 1976. Escorpiones y escorpionismo en el Perú V. Orobothriurus, un nuevo género de escorpiones altoandinos (Bothriuridae). Revista Peruana de Entomología 18 (1): 14-25.

Maury, E.A. 1978. Escorpiones y escorpionismo en el Perú VII. Nuevos hallazgos y redescripción de Brachistosternus (Microsternus) andinus Chamberlin, 1916 (Bothriuridae). Revista Peruana de Entomología 21 (1): 23-26.

Maury, E.A. 1979. Apuntes para una zoogeografía de la escorpiofauna Argentina. Acta Zoológica Lilloana 35 (2): 703-719.

Maury, E.A. 1980. Usefulness of the hemiespermatophore in the systematics of the scorpion family Bothriuridae. In J. Gruber (editor), Verhandlungen. 8. Internationaler Arachnologen-Kongress Abgehalten ander Universität für Bodenkultur Wien, 7-12 Juli, 1980:335-339. Vienna: H. Egermann.

Maury, E.A. 1981. Estudio sobre el género Bothriurus (Scorpiones, Bothriuridae). I. Catálogo y comentarios sobre el material típico. Revista del Museo Argentino de Ciencias Naturales "Bernardino Rivadavia" Entomología 4 (4): 95-111.

Maury, E.A. 1984. Redescripción de Bothriurus bocki Kraepelin, 1911 (Scorpiones, Bothriuridae). Journal of Arachnology 12 (3): 351-356.

Mello-Leitão, C. de. 1931. Notas sôbre os Bothriuridae Sul-Americanos. Arquivos do Museu Nacional 33: 75-105.

Mello-Leitão, C. de. 1932. Notas sôbre escorpiões Sul-Americanos. Arquivos do Museu Nacional 34: 9-46.

Mello-Leitão, C. de. 1934. Estudo monográfico dos Escorpiões da Republica Argentina. Octava Reunión de la Sociedad Argentina de Patología Regional: 1-97.

Mello-Leitão, C. de. 1935. On two Brasilian scorpions. Revista Chilena de Historia Natural 39: 90-93.

Mello-Leitão, C. de. 1937. Dois escorpiões SulAmericanos. Annaes da Academia Brasileira de Ciências 9 (2): 99-104.

Mello-Leitão, C. de. 1938. Notas sobre alacranes argentinos. Notas del Museo de La Plata, Zoología 3 (9): 83-95.

Mello-Leitão, C. de. 1939. Les arachnides et la zoogeographie de l'Argentine. Physis 17 (49): 601-630.

Mello-Leitão, C. de. 1945. Escorpiões sul-americanos. Arquivos do Museu Nacional, Rio de Janeiro 40: 7-468.

Mello-Leitão, C. de. 1948. In: Mello-Leitão, C. De, and J. de Araújo Feio. 1948. Notas sôbre pequeña colecção de Aracnídeos do Perú. Boletim do Museu Paraense Emilio Goeldi 10: 313-324.
Ochoa, J.A. 2004a. Filogenia del género Orobothriurus y descripción de un nuevo género de Bothriuridae (Scorpiones). Revista Ibérica de Aracnología 9: 43-73.

Ochoa, J.A. 2004b. Brachistosternus ninapo una nueva especie (Scorpiones: Bothriuridae) de los Andes occidentales en el sur del Perú. Revista Peruana de Biología 11 (2): 139-148.

Ochoa, J.A. 2005. Patrones de distribución de escorpiones de la región andina en el sur peruano. Revista Peruana de Bi-ología 12 (1): 49-68.

Ochoa, J.A., and L.E. Acosta. 2002a. Orobothriurus atiquipa, a new bothriurid species (Scorpiones) from Lomas in southern Peru. Journal of Arachnology 30: 98-103.

Ochoa, J.A., and L.E. Acosta. 2002b. Two new Andean species of Brachistosternus Pocock (Scorpiones: Bothriuridae). Euscorpius 2: 1-13.

Ochoa, J.A., and L.E. Acosta. 2003. Una nueva especie de Orobothriurus del Santuario Nacional de Ampay, Apurimac, Perú. Revista Peruana de Entomología 43: 1-6.

Ochoa, J.A., and J.C. Chaparro. 2008. Nueva especie de escorpión del género Hadruroides (Scorpiones: Caraboctoninae) de los valles interandinos de Peru. Revista Peruana de Biología 15 (1): 5-10.

Ochoa, J.A., and L. Prendini. 2010. The genus Hadruroides Pocock, 1893 (Scorpiones: Iuridae), in Peru: new records and descriptions of six new species. American Museum Novitates 3687: 1-56.

Ochoa, J.A., R. Botero-Trujillo, and L. Prendini. 2010. On the troglomorphic scorpion Troglotayosicus humiculum (Scorpiones, Troglotayosicidae), with first description of the adults. American Museum Novitates 3691: 1-19.

Ojanguren Affilastro, A.A. 2002. Brachistosternus galianoae (Scorpiones, Bothriuridae) una nueva especie de Bolivia. Revista del Museo Argentino de Ciencias Naturales "Bernardino Rivadavia" 4: 105-109.

Ojanguren Affilastro, A.A. 2003a. Un nuevo Orobothriurus (Scorpiones, Bothriuridae) de la region de Atacama, Chile. Revista Ibérica de Aracnología 7: 117-122.

Ojanguren Affilastro, A.A. 2003b. Las especies andinas del género Brachistosternus (Leptosternus) con la descripción de tres nuevas especies. Revista Ibérica de Aracnología 8: 23-36.

Ojanguren Affilastro, A.A. 2004. Sistemática y distribución de Brachistosternus (Leptosternus) intermedius Lönnberg. (Scorpiones, Bothriuridae). Physis (Buenos Aires), Sec. C 59: 29-35.

Ojanguren Affilastro, A.A. 2005. Estudio monográfico de los escorpiones de la República Argentina. Revista Ibérica de Aracnología 11: 75-241. 
Ojanguren Affilastro, A.A., and C.I. Mattoni. 2006. A new species of Brachistosternus from the Chilean central Andes (Scorpiones: Bothriuridae). Studies on Neotropical Fauna and Environment 41 (1): 79-85.

Ojanguren Affilastro, A.A., P. Agusto, J. Pizarro Araya, and C.I. Mattoni. 2007a. Two new scorpion species of genus Brachistosternus (Scorpiones: Bothriuridae) from northern Chile. Zootaxa 1623: 55-68.

Ojanguren Affilastro, A.A., C.I. Mattoni, and L. Prendini. 2007b. The genus Brachistosternus (Scorpiones: Bothriuridae) in Chile, with descriptions of two new species. American Museum Novitates 3564: 1-44.

Ojanguren Affilastro, A.A., F. Fernández Campón, S. Lagos Silnik, and C.I. Mattoni. 2009. The genus Orobothriurus Maury in central Argentina with the description of a new species from El Nevado mountain chain in Mendoza (Scorpiones: Bothriuridae). Zootaxa 2209: 28-42.

Ojanguren Affilastro, A.A., and M.J. Ramírez. 2009. Phylogenetic analysis of the scorpion genus Brachistosternus (Arachnida, Scorpiones, Bothriuridae). Zoologica Scripta 38 (2): 183-198.

Péfaur, J.E. 1981. Composition and phenology of epigeic animal communities in the Lomas of southern Peru. Journal of Arid Environments 4: 31-42.

Pocock, R.I. 1899. Scorpions and spiders. In E.A. FitzGerald (editor), The highest Andes: 356358. London: Methuen.

Polis, G.A. 1990. Ecology. In G.A. Polis (editor), The biology of scorpions: 247-293. Stanford, CA: Stanford University Press.

Prendini, L. 2000. Phylogeny and classification of the superfamily Scorpionoidea Latreille 1802 (Chelicerata, Scorpiones): an exemplar approach. Cladistics 16: 1-78.

Prendini, L. 2003. A new genus and species of bothriurid scorpion from the Brandberg Massif, Namibia, with a reanalysis of bothriurid phylogeny and a discussion of the phylogenetic position of Lisposoma Lawrence. Systematic Entomology 28: 149-172.

Prendini, L. 2004. The systematics of southern African Parabuthus Pocock (Scorpiones, Buthidae): revisions to the taxonomy and key to the species. Journal of Arachnology 32: 109-186.

Prendini, L. 2006. Scorpiones. In McGraw-Hill encyclopedia of science and technology. Access Science@McGraw-Hill. Available online (http:// www.accessscience.com). [doi 10.1036/1097-8542. 607800]
Prendini, L., and W.C. Wheeler. 2005. Scorpion higher phylogeny and classification, taxonomic anarchy, and standards for peer review in online publishing. Cladistics 21: 446-494.

Rein, J.O. 2007. Taxonomic updates in scorpions (Arachnida: Scorpiones) since the publication of the Catalogue of the Scorpions of the World (1758-1998) (Fet, Sissom, Lowe, and Braunwalder, 2000). Part 1: Bothriuridae. The Scorpion Files Occasional Papers 1: 1-12, Available online (http://www.ub.ntnu.no/scorpion-files/sf_ occationalpapers.php).

Roig Alsina, A. 1973. Fauna y ecosistema del oeste arido argentino. III. Escorpiofauna de la provincia de Mendoza. Deserta 4: 195-208.

Roig Alsina, A. 1977. Una nueva especie de escorpión andino de Mendoza, República Argentina (Bothriuridae). Physis Sección C 37 (93): 255-259.

Serra, M.T. 1997. Prosopis tamarugo. FAO RLC Agroforestería - Arboles en zonas áridas. FAO, Santiago.

Sissom, W.D. 1990. Systematics, biogeography and paleontology. In G.A. Polis (editor), The biology of scorpions, 64-160. Stanford, CA: Stanford University Press.

Soleglad, M.E., and V. Fet. 2003. High-level systematics and phylogeny of the extant scorpions (Scorpiones: Orthosterni). Euscorpius 11: 1-172.

Squeo, F.A., R. Osorio, and G. Arancio. 1994. Flora de Los Andes de Coquimbo: Cordillera de Doña Ana. La Serena: Ediciones Universidad de La Serena, 168 pp.

Stahnke, H.L. 1970. Scorpion nomenclature and mensuration. Entomological News 81: 297-316.

Stahnke, H.L. 1972. U.V. light, a useful field tool. BioScience 22 (10): 604-607.

Thorell, T. 1877 [1876]. Études scorpiologiques. Atti della Società Italiana di Scienze Naturali 19: 75-272.

Vachon, M. 1952. Étude sur les Scorpions. Alger: Institut Pasteur d'Algérie, 482 pp.

Vachon, M. 1973 [1974]. Étude des caractères utilisés pour classer les familles et les genres de scorpions (Arachnides). 1. La trichobothriotaxie en arachnologie. Sigles trichobothriaux et types de trichobothriotaxie chez les scorpions. Bulletin du Muséum National d'Histoire Naturelle (Paris) Ser. 3 140: 857-958.

Werner, F. 1916. Ueber einige Skorpione und Glieder-spinnen des Naturhistorischen Museums in Wiesbaden. Jahrbücher des Nassauischen Vereins für Naturkunde 69: 79-97. 


\section{APPENDIX 1}

\section{CHECKLIST OF TAXA ASSIGNED TO \\ OrobothriURUS MAURY, 1976, AT VARIOUS TIMES}

Bothriurus dumayi Cekalovic, 1974: transferred to Orobothriurus by Maury (1976) and returned to Bothriurus Peters, 1861, by Acosta and Ochoa (2001).

Bothriurus lampei Werner, 1916: synonymized with $O$. curvidigitus by Maury (1973).

Cercophonius brachycentrus var. $\beta$ bivittatus Thorell, 1877: transferred to Orobothriurus by Acosta (2002), elevated to species (Orobothriurus bivittatus) by Acosta (2005), and synonymized with $O$. alticola by Ojanguren Affilastro et al. (2009).

Orobothriurus alticola (Pocock, 1899): originally described as Bothriurus alticola Pocock, 1899, and transferred to Orobothriurus by Maury (1976), becoming type species of the genus.

Orobothriurus ampay Ochoa and Acosta, 2003.

Orobothriurus atiquipa Ochoa and Acosta, 2002.

Orobothriurus calchaqui, n. sp.

Orobothriurus compagnuccii, n. sp.

Orobothriurus curvidigitus (Kraepelin, 1911): originally described as Bothriurus curvidigitus Kraepelin, 1911, and transferred to Orobothriurus by Maury (1976).

Orobothriurus famatina Acosta, 2001.

Orobothriurus grismadoi Ojanguren Affilastro et al., 2009.

Orobothriurus huascaran, n. sp.

Orobothriurus lourencoi Ojanguren Afillastro, 2003: although currently placed in Orobothriurus, this species will be placed in another genus (Mattoni et al., in litt.).

Orobothriurus paessleri (Kraepelin, 1911): originally described as Bothriurus paessleri Kraepelin, 1911, and transferred to Orobothriurus by Maury (1976).

Orobothriurus parvus Maury, 1976: previously misidentified as Bothriurus borellianus Mello-Leitão, 1934, Bothriurus chilensis (Molina, 1782), and Bothriurus peruvianus Mello-Leitão, 1948, by Bücherl, 1959b; Aguilar and Meneses, 1970; and Francke, 1974, respectively.

Orobothriurus quewerukana, n. sp.: confused with Bothriurus dumayi by Maury (1976).

Orobothriurus ramirezi, n. sp.

Orobothriurus tamarugal, n. sp.

Orobothriurus wawita Acosta and Ochoa, 2000.

Pachakutej crassimanus (Maury, 1976): originally described as Orobothriurus crassimanus Maury, 1976, transferred to Pachakutej by Ochoa (2004a).

Pachakutej inca (Maury, 1976): originally described as Orobothriurus inca Maury, 1976, transferred to Pachakutej by Ochoa (2004a).

Pachakutej iskay (Acosta and Ochoa, 2001): originally described as Orobothriurus iskay Acosta and Ochoa, 2001, and transferred to Pachakutej by Ochoa (2004a).

Pachakutej peruvianus (Mello-Leitão, 1948): originally described as Bothriurus peruvianus Mello-Leitão,
1948, transferred to Orobothriurus by Maury (1976), and to Pachakutej by Ochoa (2004a).

\section{APPENDIX 2}

\section{LIST OF 65 CHARACTERS SCORED FOR 15 SPECIES OF OROBOTHRIURUS MAURY, 1976, AND 15 OUTGROUP TAXA, FROM MATTONI ET AL. (IN LITT.)}

Character states are scored 0-3, unknown (?) and inapplicable (-). Characters from previous analyses that correspond partially or entirely to those in the present matrix are as follows: O2004 = Ochoa (2004a); OA\&R2009 = Ojanguren Affilastro and Ramírez (2009); P2003 = Prendini (2003).

\section{Pigmentation pattern}

0 . Tergites I-IV, pigmentation: entirely pigmented $(0)$; paired spots sublaterally, unpigmented area medially (1) [O2004: 0; OA\&R2009: 1].

1. Tergite VII, pigmentation: entirely pigmented $(0)$; paired spots sublaterally, unpigmented area medially (1); inapplicable (-).

2. Metasomal segments II and III, dorsal surfaces, pigmentation: absent, unpigmented (0); subtriangular spot medially, it may be divided by unpigmented line medially (1).

3. Metasomal segments I-III, dorsal surfaces, pigmentation along DL carinae: absent, unpigmented (0); reticulate lines (1).

4. Metasomal segments IV and V, ventral surfaces, VM stripe: contiguous with VL stripe posteriorly (0); not contiguous with VL stripe posteriorly (1); absent (2). [OA\&R2009: 5].

5. Telson vesicle, ventral and lateral surface, coloration ( $₫)$ : similar to + , pigmented $(0)$; different from q, unpigmented, with glandular, light yellow coloration (1).

\section{Carapace}

6. Anterior margin, shape: sublinear or with shallow median notch (0); with weak median projection (epistome) (1). [OA\&R2009: 7].

7. Anteromedian longitudinal sulcus, length ( $₫)$ : complete (0); vestigial (1). [P2003: 4; O2004: 1; OA\&R2009: 8].

\section{Chelicera}

8. Movable finger, subdistal teeth, number: one (0); two (1). [P2003: 9; O2004: 2; OA\&R2009: 6].

\section{Pedipalps}

9. Femur, length $(\delta)$ : greater than three times width (0); less than three times width (1). [O2004: 3; OA\&R2009: 75].

10. Femur, dorsal surface, shape: slightly convex, DE and DI carinae situated in different axes (0); flat, DE and DI carinae situated in same axis (1). [O2004: 4].

11. Chela, shape: similar in both sexes or narrower (length/width ratio of pedipalp chela smaller) in $\delta$ than $+(0)$; more robust (length/width ratio of 
pedipalp chela greater) in $\delta$ than $q$ (1). [O2004: 5; OA\&R2009: 60].

12. Chela manus, external surfaces, shape (o): prismatic (0) flat (1). [O2004: 6].

13. Chela manus, surfaces adjacent to DMA carinae, shape (ई): D-DMA-DI carinae forming angle greater than $90^{\circ}(0)$; D-DMA-DI carinae forming angle less than $90^{\circ}$. [O2004: 7].

14. Chela manus, DMA, DI and VM carinae, granulation ( $\hat{\sigma})$ : absent, smooth (0); present, finely and densely granular (1).

15. Chela movable finger, shape ( $\delta)$ : straight (0); curved (1). [O2004: 8].

16. Chela manus, secondary sexual apophysis ( $\hat{\sigma})$ : present (0); absent (1). [O2004: 9].

17. Chela manus, secondary sexual apophysis, shape ( 3 ): conical (0); spiniform (1); lobate (2); conicaltruncate (3); hornlike (4); inapplicable (-). [P2003: 25; O2004: 10; OA\&R2009: 61].

18. Chela manus, secondary sexual apophysis, position $(\delta)$ : close to base of fixed finger, distal to trichobothrium ib (0); in distal third of manus, proximal to trichobothrium $i b$ (1).

19. Chela fixed finger, group of granules at base $(\hat{\delta})$ : absent (0); present (1). [P2003: 26; O2004: 11; OA\&R2009: 62].

20. Chela fingers, median denticle rows, number: single row (0); multiple rows (1). [P2003: 27; O2004: 12; OA\&R2009: 64].

21. Chela movable finger, median denticle row, relative denticle size: all denticles equal in size (0); basal denticle greatly enlarged, approximately five times larger than other denticles (1).

\section{Trichobothria}

22. Chela manus, trichobothrium $i b$, position $(\delta)$ : situated at base of ventral side of secondary sexual apophysis, visible in ventral view (0); situated at base of internal side of apophysis, not visible in ventral view (1); situated more distal to apophysis, visible in ventral view (2). [O2004: 13].

23. Chela manus, trichobothrium Esb, position: intermediate between $E b_{1}$ and $E b_{2}(0)$; dorsal to $E b_{2}$ (1); intermediate between $E b_{2}$ and $E b_{3}$ (2). [O2004: 14; OA\&R2009: 53].

24. Chela manus, trichobothrium $E t_{3}$, position: distal to Est (0); in same axis as Est (1); proximal to Est (2). [O2004: 15; OA\&R2009: 54].

25. Chela manus, trichobothrium $V_{2}$, position: forming obtuse angle $\left(<180^{\circ}\right)$ with $V_{1}$ and $V_{3}(0)$; in same axis as $V_{1}$ and $V_{3}(1)$. [O2004: 16].

26. Chela fixed finger, trichobothrium $d s t$, position: in same axis as est (0); proximal to est (1). [O2004: 17].

27. Chela manus, trichobothrium $D b$, position: close to $D t(0)$; equidistant between $D t$ and $E b_{3}$ (1). [O2004: 18].

28. Chela manus, trichobothrium $E t_{5}$, position: forming acute angle $\left(<90^{\circ}\right)$ with $e b$ and $E t_{4}(0)$; forming obtuse angle $\left(<180^{\circ}\right)$ with $e b$ and $E t_{4}(1)$. [O2004: 19].

Legs

29. Legs III and IV, telotarsi, ventrosubmedian spiniform macrosetae, number of pairs: three (0); more than five (1). [O2004: 20; OA\&R2009: 39].

\section{Genital operculum}

30. Genital sclerites, shape ( $(+)$ : rhomboid (0); posteriorly elongated, anterior edge slightly rounded (1).

\section{Sternites and Metasoma}

31. Sternite VII, carinae: absent (0); VL and/or VSM carinae present (1). [O2004: 21; OA\&R2009: 81].

32. Metasomal segment I, VSM carinae ( + ): absent (0); present (1). [O2004: 22; OA\&R2009: 91].

33. Metasomal segment II, VSM carinae ( + ): present (0); absent (1). [O2004: 23; OA\&R2009: 92].

34. Metasomal segment II, VSM carinae $(\hat{\delta})$ : present (0); absent (1). [O2004: 24].

35. Metasomal segment III, VSM carinae $(+)$ : present (0); absent (1). [O2004: 25].

36. Metasomal segment IV, VSM carinae (q): present (0); absent (1). [O2004: 26; OA\&R2009: 97].

37. Metasomal segment IV, VSM carinae ( $\delta$ ): present (0); absent (1). [O2004: 27].

38. Metasomal segment V, VL carinae $(\hat{\delta})$ : present in more than half of segment $(0)$; restricted the posterior third (1); absent or reduced to few granules posteriorly (2). [O2004: 28; OA\&R2009: 104].

39. Metasomal segment V, VL and VSM carinae, relative orientation: well separated, diverging (0); adjacent, subparallel (1); inapplicable (-). [O2004: 29].

40. Metasomal segment V, VSM carinae, orientation in posterior third: subparallel, not diverging (0); diverging slightly (1), diverging strongly, forming arc (2). [P2003: 82; O2004: 30; OA\&R2009: 101; additive].

41. Metasomal segment V, VM carina: present, well developed (0), vestigial or absent (1). [O2004: 31].

42. Metasomal segment III, length ( $\delta)$ : less than or equal to width (0); greater than width (1). [O2004: 32; OA\&R2009: 105]

43. Metasomal segment $\mathrm{V}$, length $(\delta)$ : less than or equal to twice width $(0)$; greater than twice width (1). [O2004: 33; OA\&R2009: 106].

\section{Macrosetae}

44. Pedipalp femur, dorsal macroseta $\left(M_{1}\right)$ situated near $d$ trichobothrium: present (0), absent (1). [O2004: 34].

45. Metasomal segment I, VSM macrosetae, number of pairs: two (0); three (1). [O2004: 35; OA\&R2009: 83].

46. Metasomal segment III, VSM setae, number of pairs: two (0); three (1). [O2004: 36].

47. Metasomal segment IV, VSM setae, number of pairs: two (0); three (1); four (2). [O2004: 37; OA\&R2009: 87; additive].

\section{Hemispermatophore}

48. Apex of lamina, shape of distal margin: sub triangular (0); rounded or subquadrangular (1). [O2004: 38].

49. Apex of lamina, length: greater than length of frontal crest (0); less than length of frontal crest (1); inapplicable (-).

50. Distal crest, shape: curved with respect to ventral border (0); parallel to ventral border (1); straight and diagonal to ventral border (2). [O2004: 40].

51. Semicircular depression at base of lamina, development: well developed, extended to basal 
portion (0); slightly developed (1); obsolete (2). [O2004: 41; additive].

52. Posterodistal fold: absent (0); present (1). [O2004: 42].

53. Frontal crest: absent (0); present (1). [O2004: 43; OA\&R2009: 35].

54. Frontal crest, incision in distal border: absent (0); present (1); inapplicable (-). [O2004: 44].

55. Frontal crest, shape: undivided, with continuous, smooth borders, without undulations (0); divided in two parts, proximal oblique part with two lateral folds, distal part straight usually parallel to ventral margin of lamina, with lateral projections on each side (1); divided in two parts, distal part sinuous with strong undulation in dorsal border (2).; inapplicable (-). [O2004: 45].

56. Frontal crest, lateral projections of distal part, shape: reduced, length of projections less than length of proximal oblique part (0); elongated, length of distal part greater than proximal oblique part (1); inapplicable (-). [O2004: 47].
57. Capsule, internal lobe, development: similarly developed to external lobe (0); considerably more developed than external lobe (1). [O2004: 49].

58. Capsule, internal lobe, spiniform apophysis on external surface: absent (0); present (1). [O2004: 50].

59. Capsule, internal lobe, sclerotized apophysis on internal fold: absent (0); present (1). [O2004: 51].

60. Capsule, basal lobe, tortuous stem, subdistal spatulate dilation ending in terminal process: absent (0); present (1). [O2004: 52].

61. Capsule, basal lobe, subdistal dilation, shape: widened (0); oval (1); elongated (2); inapplicable (-). [O2004: 53].

62. Capsule, basal lobe, terminal process, shape: short (0); elongated (1); inapplicable (-). [O2004: 54].

63. Capsule, basal lobe, spatulate terminal process: absent (0); present (1). [O2004: 55].

64. Capsule, basal lobe, papillose fold: absent (0); present (1). [O2004: 56]. 